\title{
$\Psi$
}

Universidade de Brasília

Faculdade de Comunicação

Programa de Pós-Graduação

Carolina Guedes Camelo De Jorge

\section{A representação social do microempreendedor individual na publicidade do Sebrae}




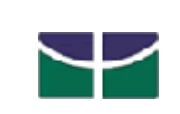

\title{
Universidade de Brasília
}

Faculdade de Comunicação

Programa de Pós-Graduação

\section{A representação social do microempreendedor individual na publicidade do Sebrae}

\author{
Dissertação apresentada ao Programa de \\ Pós-Graduação em Comunicação da \\ Universidade de Brasília como requisito \\ para obtenção do grau de Mestre em \\ Comunicação pela linha de pesquisa \\ Imagem, Som e Escrita.
}

Orientador: Prof. Dr. Asdrúbal Borges Formiga Sobrinho

Brasília 


\title{
A REPRESENTAÇÃO SOCIAL DO MICROEMPREENDEDOR INDIVIDUAL NA PUBLICIDADE DO SEBRAE
}

\begin{abstract}
Dissertação apresentada como requisito para obtenção do grau de Mestre em Comunicação pelo Programa de Pós-Graduação em Comunicação da Universidade de Brasília, em 1 de dezembro de 2015, defendido e aprovado pela banca examinadora abaixo assinada:
\end{abstract}

Prof. Dr. Asdrúbal Borges Formiga Sobrinho (presidente)

Programa de Pós-graduação em Comunicação da Universidade de Brasília

Prof. Dr. João José Azevedo Curvello (membro interno)

Programa de Pós-graduação em Comunicação da Universidade de Brasília

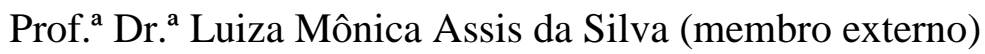

Universidade Católica de Brasília

Prof. ${ }^{a}$ Dr. ${ }^{a}$ Gabriela Pereira de Freitas (suplente)

Programa de Pós-graduação em Comunicação da Universidade de Brasília 
"Thanks for the adventure. Now go have a new one!" Ellie (Up) 


\section{AGRADECIMENTOS}

$\mathrm{Na}$ língua portuguesa, empregamos a palavra obrigado para agradecer. Ela tem sua origem no latim obligare e significa "ligar por todos os lados, ligar moralmente". Em outras palavras, refere-se ao vínculo estabelecido entre dois indivíduos por um favor realizado. Quem agradece diz obrigado porque reconhece que recebeu um benefício e assume, assim, uma dívida de gratidão.

Quando penso nos acontecimentos dos últimos dois anos, no meu retorno à vida acadêmica e em toda a jornada de aprendizado até aqui, vejo que tenho muitos motivos para agradecer. Fico extremamente feliz pelos obrigados que deixarei registrados agora e, principalmente, feliz pelos vínculos criados e fortalecidos ao longo dessa caminhada.

Obrigada a Deus, Nossa Senhora e todos os espíritos de luz, por me permitirem caminhar ao lado da minha família com alegria, amor e saúde.

Obrigada, Fernando e Heitor, amores da minha vida, por me inspirarem todos os dias.

Obrigada a meus pais, Theresa e Guilherme, meus exemplos, sempre.

Obrigada, Mila e Arthur, por acreditarem em mim.

Obrigada, Lucília, Nilton, Nádia, Theo e Álvaro, por trazerem leveza aos meus dias.

Obrigada, vovó Zuzu, vovó Lucy e tia Leniza, pela torcida tão, tão, tão grande.

Obrigada, vovô Balulo e vovô Marquinho, por cuidarem de mim, mesmo de longe.

Obrigada, Val e Iracy, por me mostrarem diariamente que trabalhar duro vale a pena.

Obrigada, amigos queridos que estão sempre por perto: Márcia, Aaron, Elisa, Cissa, Amanda, Luana, Lulu, Marina, Gabriela e Caroline.

Obrigada, professor e orientador Asdrúbal Borges, por me ajudar na busca incessante por conhecimento e pela dedicação à minha formação acadêmica.

Obrigada aos professores e funcionários da pós-graduação da FAC/UnB: Elen Geraldes, Tânia Montoro, Selma Regina, Janara Souza, Nélia Del Bianco.

Obrigada aos meus colegas de mestrado e doutorado, pela companhia e incentivo durante o curso.

Obrigada aos meus amigos do Sebrae que me ajudaram nessa jornada: Cândida, Dudu, Henrique, Bruna, AnaQ, Selminha, Clarice, Hélia, Celso, Roseley e tantos outros que se dedicam com tanto amor ao empreendedorismo. 
Obrigada à Universidade Corporativa Sebrae, aos colegas Alzira Vieira, Paulo Volker, professor Alexandre Hamilton e, principalmente, a Hebe Bezerra, pela competência e organização do programa de mestrado do Sebrae.

Obrigada aos amigos das agências Lew'LaralTBWA, Giacometti e Nova/SB, em especial: Luciana, Paulinho, Clara, Marina, Alex, Silvinha e Ricardo.

Obrigada Alê e Marina, pela disponibilidade e energia positiva.

Obrigada a todos aqueles que acreditam no empreendedorismo e que, por meio de seus negócios, fazem do Brasil um país melhor. 


\section{RESUMO}

Este trabalho apresenta uma análise sobre a representação social do microempreendedor individual (MEI) na publicidade do Sebrae, Serviço Brasileiro de Apoio às Micro e Pequenas Empresas. Para isso, utiliza como referencial metodológico a hermenêutica de profundidade, proposta pelo sociólogo John Thompson, composta por três fases distintas. A primeira, chamada de análise sócio histórica, contextualiza o objeto de estudo e apresenta os cenários e conhecimentos relevantes à investigação: o Sebrae, o microempreendedor individual, os conceitos de comunicação e as estratégias de persuasão, a teoria das representações sociais e os processos de identificação. A segunda, análise formal, direciona a discussão para as formas simbólicas em si, ou seja, a publicidade veiculada pelo Sebrae e voltada para o MEI. São analisadas, ao todo, vinte e uma diferentes peças publicitárias criadas e veiculadas pela entidade, entre os anos de 2009 e 2014. A terceira fase da hermenêutica de profundidade, chamada de interpretação ou reinterpretação, investiga tanto as esferas de produção, quanto de recepção da publicidade do Sebrae. Como resultado das análises, percebe-se a dificuldade em objetivar o conceito de microempreendedor individual, o que destaca a complementaridade entre texto e imagem, fundamental para o sucesso da comunicação. A pesquisa revela que a representação social do microempreendedor individual ainda é recente e está em processo de assimilação. O conceito é ancorado no termo "trabalha por conta própria”, mas sua objetivação adquire imagens diversas. O público-alvo da mensagem é impactado pela publicidade do Sebrae e a compreende, uma vez que não espera ver nela um espelho de si mesmo, mas sim uma tentativa de representação da categoria empresarial a qual pertence. O mesmo público também percebe a dificuldade de objetivação do conceito. Além disso, entende a importância e necessidade de capacitação empresarial, assimilando sua identidade como empreendedor, empresário e, por fim, microempreendedor individual.

Palavras-chave: comunicação publicitária, representações sociais, identidade, microempreendedor individual, empreendedorismo. 


\section{ABSTRACT}

This work presents an analysis of the social representation of the individual microentrepreneur (MEI) in the Micro and Small Business Support Service's advertising. To achieve its goals, this research approaches the object through John B. Thompson's depth hermeneutics, which includes three different stages. The first, called social-historic analysis, contextualizes the object of study and presents all sceneries and knowledge relevant to the investigation: Sebrae, the individual microentrepreneur, communication concepts and persuasion strategies, social representations theory and processes of identification. The second stage, formal discursive analysis, debates symbolic forms, namely Sebrae's advertising campaigns that addresses MEI. In all, twenty-one different ads are analysed created and broadcasted by the company, between 2009 and 2014. The third stage of the depth hermeneutics, called interpretation or reinterpretation, addresses both areas of Sebrae's advertising production and reception. As a result, analysis show it is difficult to objectify the concept of the individual microentrepreneur, highlighting the complementarity between text and image, which is basic to the success of the communication process. This research shows that the social representation of the individual microentrepreneur is a recent phenomenon and is still in construction. The concept is anchored in the expression "works on own account", but its objectification acquires numerous images. Sebrae's advertising reaches its target audience. The public understands the message because they do not expect to see their image as a perfect mirror, but in fact, an attempt to represent the social category they are in. This same public notices the difficulty of objectification of the concept. Moreover, they comprehend the importance and need of entrepreneurial empowerment, linking their identities to concepts such as entrepreneur, businessperson and individual microentrepreneur.

Keywords: advertising, social representations, identity, individual microentrepreneur, entrepreneurship. 


\section{SUMÁRIO}

I - O SEBRAE E OS PEQUENOS NEGÓCIOS DO BRASIL

1. INTRODUÇÃO 17

2. O SEBRAE 18

2.1. O microempreendedor individual 23

2.2. O impacto da criação do MEI 25

2.3. O SEI - Sebrae Empreendedor Individual 28

II - FUNDAMENTAÇÃO TEÓRICA

3. A COMPLEXIDADE DO FENÔMENO COMUNICACIONAL 30

3.1. O processo comunicacional $\quad 30$

3.1.1. As imagens $\quad 32$

3.1.2. As funções da linguagem $\quad 36$

3.2. As teorias da comunicação $\quad 40$

3.3. Os meios de comunicação de massa 43

3.3.1. A publicidade 46

4. AS FRONTEIRAS DA PESQUISA EM COMUNICAÇÃO 51

5. A REPRESENTAÇÃO E A BUSCA PELA IDENTIFICAÇÃO 53

5.1. As representações sociais $\quad 54$

5.2. Os processos de identificação $\quad 62$

III - OBJETIVOS

6. OBJETIVOS DE PESQUISA $\quad 70$

$\begin{array}{ll}\text { 6.1. Geral } & 70\end{array}$

6.2. Específicos $\quad 70$

IV - PROCEDIMENTOS METODOLÓGICOS 
V - ANÁLISE DO CORPUS DE PESQUISA E DISCUSSÃO DE RESULTADOS

8. QUEM É O MEI NA COMUNICAÇÃO DO SEBRAE? 78

$\begin{array}{ll}\text { 8.1. Análise de imagens } & 78\end{array}$

8.2. O microempreendedor individual na publicidade do Sebrae 83

8.2.1. Chegou a sua vez - Giacometti $2009 \quad 87$

8.2.2. Empreendedor Individual - Giacometti $2010 \quad 93$

8.2.3. Ei. Tá na hora de se formalizar - Lew’LaralTBWA $2010 \quad 99$

8.2.4. 1 Milhão - Lew’LaralTBWA 2011

8.2.5. Sebrae Empreendedor - Giacometti $2012 \quad 115$

8.2.6. Sebrae 40 Anos - Giacometti $2012 \quad 118$

8.2.7. MEI Card - Giacometti 2013

8.2.8. Folder SEI - Lew'LaralTBWA $2013 \quad 128$

8.2.9. Sebrae Apresenta - Giacometti $2014 \quad 130$

8.3. Resultado das análises $\quad 134$

9. O ANTES E O DEPOIS DA REPRESENTAÇÃO DO MICROEMPREENDEDOR 140 INDIVIDUAL

9.1. O antes: a produção da mensagem 141

9.1.1. Quem cria a mensagem 144

9.1.2. A representação social do MEI 150

$\begin{array}{ll}\text { 9.1.2.1. A ancoragem } & 150\end{array}$

$\begin{array}{ll}\text { 9.1.2.2. A objetivação } & 150\end{array}$

9.1.2.3. As representações afins 152

9.1.2.4. A representação social do MEI pela diferenciação 157

9.1.3. Como deve ser a comunicação direcionada ao MEI? 158

9.1.4. O diminutivo e questões de gênero 160

9.2. O depois: a recepção da mensagem 161

9.2.1. O participante da Semana do Microempreendedor Individual 165

$\begin{array}{ll}\text { 9.2.2. O dia a dia do empreendedorismo } & 167\end{array}$

9.2.3. A representação social do MEI pelo MEI 169 
$\begin{array}{llr}\text { 9.2.3.1. A ancoragem } & 169\end{array}$

$\begin{array}{lll}\text { 9.2.3.2. } & \text { A objetivação } & 170\end{array}$

$\begin{array}{lll}\text { 9.2.3.3. } & \text { As representações afins } & 173\end{array}$

9.2.3.4. A representação imagética do microempreendedor individual na 174 publicidade do Sebrae

10. CONCLUSÃO 179

10.1. Limitações da pesquisa 181

REFERÊNCIAS 


\section{LISTA DE FIGURAS}

Figura 1 - Diferenciação feita pelo Sebrae entre os termos empreendedor e empresário

Figura 2 - Processo comunicacional

Figura 3 - Anúncios da organização britânica Women's Aid alertam para a violência doméstica, em 2007

Figura 4 - Esferas de interesse da teoria da mídia

Figura 5 - Ancoragem e objetivação

Figura 6 - Resumo do conceito de identidade padrão

64

Figura 7 - O modelo de identidade de Burke e Stets

65

Figura 8 - Quadro resumo da dinâmica entre a representação social do MEI, sua

imagem na publicidade do Sebrae e a identidade social do público-alvo

Figura 9 - Formas de investigação hermenêutica

Figura 10 - Investigação hermenêutica desta pesquisa 77

Figura 11 - Ano 2009, agência Giacometti, campanha “Chegou a sua vez”. Mídia: 87 cartaz

Figura 12 - Ano 2009, agência Giacometti, campanha “Chegou a sua vez”. Mídia: cartilha

Figura 13 - Ano 2010, agência Giacometti, campanha "Empreendedor Individual". Mídia: revista

Figura 14 - Ano 2010, agência Giacometti, campanha "Empreendedor Individual”. Mídia: filme

Figura 15 - Ano 2010, agência Giacometti, campanha "Empreendedor Individual”. Mídia: merchandising televisivo

Figura 16 - Ano 2010, agência Lew’LaralTBWA, campanha "Ei. Tá na hora de se formalizar". Mídia: revista

Figura 17 - Ano 2010, agência Lew'LaralTBWA, campanha "Ei. Tá na hora de se formalizar". Mídia: folder

Figura 18 - Ano 2010, agência Lew’LaralTBWA, campanha "Ei. Tá na hora de se 
Figura 19 - Ano 2010, agência Lew’LaralTBWA, campanha “Ei. Tá na hora de se

formalizar". Mídia: revista

Figura 20 - Ano 2010, agência Lew'LaralTBWA, campanha "Ei. Tá na hora de se formalizar". Mídia: folder

Figura 21 - Ano 2010, agência Lew’LaralTBWA, campanha "Ei. Tá na hora de se formalizar". Mídia: folder

Figura 22 - Ano 2011, agência Lew'LaralTBWA, campanha "Semana do Empreendedor Individual". Mídia: filme

Figura 23 - Ano 2012, agência Giacometti, campanha "Sebrae Empreendedor".

Mídia: web

Figura 24 - Ano 2012, agência Giacometti, campanha "Sebrae Empreendedor".

Mídia: web

Figura 25 - Ano 2012, agência Giacometti, campanha "Sebrae 40 anos". Mídia: revista

Figura 26 - Ano 2012, agência Giacometti, campanha "Sebrae 40 anos". Mídia: revista

Figura 27 - Ano 2012, agência Giacometti, campanha "Sebrae 40 anos". Mídia: filme

Figura 28 - Ano 2013, agência Giacometti, campanha "MEI Card". Mídia: cartilha

Figura 29 - Ano 2013, agência Lew'LaralTBWA, campanha "Semana do

Microempreendedor Individual". Mídia: folder

Figura 30 - Ano 2014, agência Giacometti, campanha "Sebrae Apresenta". Mídia: revista

Figura 31 - Ano 2014, agência Giacometti, campanha "Sebrae Apresenta". Mídia: filme

Figura 32 - Tenda principal da Semana do Microempreendedor Individual no 162 centro de Ceilândia

Figura 33 - Folder da Semana do MEI e formulário de avaliação das oficinas

Figura 34 - Imagens de microempreendedores individuais apresentadas no livro 5 anos - Microempreendedor Individual - MEI: um fenômeno de inclusão produtiva

Figura 35 - Imagens utilizadas nas dinâmicas dos grupos focais

Figura 36 - Ano 2011, agência Lew'LaralTBWA, campanha "Semana do 
Figura 37 - Leiaute da campanha de divulgação da Semana do

Microempreendedor Individual de 2015 


\section{LISTA DE TABELAS}

Tabela 1 - Detalhamento do posicionamento de marca do Sebrae

Tabela 2 - Segmentação do público-alvo do Sebrae

Tabela 3 - Categorias de negócio participantes dos grupos de discussão 26

Tabela 4 - Oficinas SEI 28

Tabela 5 - Ênfase no fator determina a função da linguagem 37

Tabela 6 - Roteiro para análise de imagens publicitárias do MEI na comunicação do Sebrae

Tabela 7 - Campanhas criadas e veiculadas pelo Sebrae para o MEI entre 2009 e 2014

Tabela 8 - Critérios de seleção das campanhas analisadas na investigação

Tabela 9 - Características identificadas nas peças publicitárias do Sebrae direcionadas ao MEI

Tabela 10 - Representação social do MEI nas peças publicitárias do Sebrae

Tabela 11 - Principais características das peças publicitárias do Sebrae direcionadas ao MEI

Tabela 12 - A representação social do MEI na publicidade do Sebrae

Tabela 13 - A representação social do MEI na esfera da produção da mensagem

Tabela 14 - Expressões utilizadas pelos entrevistados para caracterizar o MEI como "cara comum"

Tabela 15 - Atividades empreendedoras desempenhadas pelos participantes dos grupos focais

Tabela 16 - A representação social do MEI na esfera da recepção da mensagem 


\section{LISTA DE ABREVIATURAS, SIGLAS E SÍMBOLOS}

\begin{tabular}{|c|c|}
\hline CCEB & Critério de Classificação Econômica Brasil \\
\hline CGU & Controladoria Geral da União \\
\hline CNPJ & Cadastro Nacional de Pessoa Jurídica \\
\hline DAS & Documento de Arrecadação Simplificada \\
\hline DASN-SIMEI & Declaração Anual do Simples Nacional do Microempreendedor Individual \\
\hline DF & Distrito Federal \\
\hline EI & Empreendedor Individual \\
\hline EPP & Empresa de Pequeno Porte \\
\hline Fenacon & $\begin{array}{l}\text { Federação Nacional das Empresas de Serviços Contábeis e das Empresas } \\
\text { de Assessoramento, Perícias, Informações e Pesquisas }\end{array}$ \\
\hline GEM & Global Entrepreneurship Monitor \\
\hline IBGE & Instituto Brasileiro de Geografia e Estatística \\
\hline ICMS & Imposto Sobre Circulação de Mercadorias e Serviços \\
\hline INSS & Instituto Nacional do Seguro Social \\
\hline ISS & Imposto Sobre Serviços \\
\hline ME & Microempresa \\
\hline MEI & Microempreendedor Individual \\
\hline QR Code & Quick Response Code \\
\hline Sebrae & Serviço Brasileiro de Apoio às Micro e Pequenas Empresas \\
\hline SEI & Sebrae Empreendedor Individual \\
\hline SP & São Paulo \\
\hline TCU & Tribunal de Contas da União \\
\hline TV & Televisão \\
\hline UAI & Unidade de Atendimento Individual \\
\hline UGE & Unidade de Gestão Estratégica \\
\hline UMC & Unidade de Marketing e Comunicação \\
\hline UPP & Unidade de Políticas Públicas \\
\hline
\end{tabular}




\section{I - O SEBRAE E OS PEQUENOS NEGÓCIOS DO BRASIL}

\section{INTRODUÇÃO}

A investigação apresentada neste trabalho surge de uma inquietação da autora, analista de comunicação do Sebrae, Serviço Brasileiro de Apoio às Micro e Pequenas Empresas, sobre a efetividade das campanhas publicitárias criadas pela entidade para vender seus produtos e serviços e, principalmente, para mostrar ao micro e pequeno empreendedor brasileiro que ele é parte importante da economia do país.

Por meio de pesquisas de mercado encomendadas às agências de publicidade que atendem à entidade, é possível levantar informações sobre os hábitos de consumo de mídia do micro e pequeno empresário. Entretanto, há uma aparente lacuna nos conhecimentos sobre o público-alvo do Sebrae, uma vez que as decisões sobre a mensagem que será propagada, ou seja, sobre a peça criativa, não levam em consideração conhecimentos sobre os aspectos psicográficos desse público, especialmente seus processos de identificação com a mensagem veiculada.

Surge, então, um impasse: como criar material publicitário que vise persuadir seu público sem esse aporte de informação? Paralelamente, como orientar o trabalho das agências de publicidade para que seus profissionais consigam criar material que fale diretamente com o empreendedor e possibilite uma comunicação mais efetiva?

É importante ressaltar que a ausência dessas informações sobre o público-alvo não se deve a uma deficiência da estrutura corporativa do Sebrae, nem à ausência de questionamento específico passível de resposta por meio de pesquisas de mercado encomendadas a fornecedores regulares. Ao contrário, percebe-se claramente uma oportunidade de investigação científica direcionada às variáveis psicográficas dos receptores de mensagens publicitárias. Diante desse contexto, como as variáveis psicográficas influem na comunicação? Mais especificamente, como a imagem age no processo de identificação do público-alvo com a mensagem?

Para apresentar o objeto, é preciso definir que aspectos da publicidade do Sebrae serão investigados. Propõe-se realizar análise das campanhas publicitárias nacionais direcionadas aos microempreendedores individuais e veiculadas desde a criação dessa figura jurídica, em 2009, até o ano de 2014.

A expressão campanha publicitária refere-se à "soma de diversos esforços publicitários integrados e coordenados entre si, e realizados para cumprir determinados objetivos de comunicação de um anunciante" (SAMPAIO, 2003, p. 260). Filmes para televisão, anúncios 
em revistas e jornais, cartazes, banners para web, outdoors e folders são exemplos de peças publicitárias que podem fazer parte de uma campanha. Rádio, televisão, revistas, jornais, celular e internet são exemplos de meios de comunicação que, ao constituírem espaços de veiculação das peças publicitárias, formam o conjunto de ferramentas de uma campanha.

Nota-se, portanto, que campanhas publicitárias abarcam diversas variáveis, relacionadas tanto à construção de seus conteúdos e significados, quanto aos dispositivos técnicos por meio dos quais são disseminadas. $O$ advento dos meios de comunicação de massa e, consequentemente, da publicidade, transformaram o espaço social e as relações entre os indivíduos, demonstrando a importância dessa temática. Assim, é necessário recortar ainda mais o objeto de investigação. Propõe-se trabalhar as peças publicitárias que se utilizam de imagens representativas do microempreendedor individual e, desse modo, estabelecer como foco do trabalho essas imagens: as representações do microempreendedor individual e as mensagens que essas representações transmitem ao público exposto às campanhas. A pesquisa analisará todas as imagens presentes em peças publicitárias do Sebrae criadas e veiculadas entre 2009 e 2014.

Em relação ao público-alvo, é importante destacar que as campanhas analisadas, em sua maioria, incentivam a formalização do empreendedor que trabalha por conta própria e cumpre as exigências da legislação vigente para se tornar um microempreendedor individual. Assim, este trabalho não fará distinção entre o público-alvo que já é formalizado como MEI e aquele que empreende ainda na informalidade, uma vez que o Sebrae busca atingir ambos os públicos por meio de sua comunicação e a única diferença entre eles é, com efeito, a formalização de seus empreendimentos.

Diante do exposto, o objeto de estudo da pesquisa proposta pode ser resumido como as representações do microempreendedor individual nas campanhas publicitárias veiculadas pelo Sebrae nacionalmente, entre 2009 e 2014 , e os efeitos dessas representações nesse público. A pergunta de pesquisa é formulada da seguinte maneira:

Como ocorre a identificação do microempreendedor individual (MEI) face à representação que se faz desse público nas campanhas publicitárias nacionais criadas e veiculadas pelo Sebrae entre 2009 e 2014 ?

\section{O SEBRAE}

Criado em 1972, o Sebrae é uma entidade privada e sem fins lucrativos. Tem como missão "promover a competitividade e o desenvolvimento sustentável dos pequenos negócios 
e fomentar o empreendedorismo, para fortalecer a economia nacional". Sua visão institucional é "ter excelência no desenvolvimento dos pequenos negócios, contribuindo para a construção de um país mais justo, competitivo e sustentável” (SEBRAE, 2012, p. 17), e seu posicionamento de marca é "Para quem já é ou quer ser empresário, o SEBRAE é a opção mais fácil e econômica de obter informações e conhecimento para apoiar as suas decisões, porque é quem mais entende de pequenos negócios, e possui a maior rede de atendimento do país" (Id., p. 18). Há seis diferentes atributos expressos por esse posicionamento. O Sebrae detalha esses atributos a partir da divisão do posicionamento, conforme apresentado na tabela 1 .

Tabela 1 - Detalhamento do posicionamento de marca do Sebrae

\begin{tabular}{|c|c|c|}
\hline POSICIONAMENTO & ATRIBUTO & COMENTÁRIO \\
\hline $\begin{array}{l}\text { Para quem já é ou quer ser } \\
\text { empresário, }\end{array}$ & $\begin{array}{l}\text { Para empresários e } \\
\text { empreendedores }\end{array}$ & $\begin{array}{l}\text { O Sebrae oferece informações e soluções } \\
\text { tanto para quem quer abrir uma pequena } \\
\text { empresa, quanto para quem já tem uma } \\
\text { pequena empresa consolidada }\end{array}$ \\
\hline $\begin{array}{l}\text { o SEBRAE é a opção mais } \\
\text { fácil }\end{array}$ & Facilidade de acesso & É fácil fazer negócios com o Sebrae \\
\hline $\begin{array}{l}\text { o SEBRAE é a opção mais } \\
\text { econômica }\end{array}$ & $\begin{array}{l}\text { É a opção mais em } \\
\text { conta }\end{array}$ & $\begin{array}{l}\text { Considero que os serviços do Sebrae } \\
\text { apresentam o melhor custo-benefício do } \\
\text { mercado }\end{array}$ \\
\hline $\begin{array}{l}\text { de obter informações e } \\
\text { conhecimento para apoiar } \\
\text { as suas decisões }\end{array}$ & $\begin{array}{l}\text { Oferece } \\
\text { conhecimento } \\
\text { relevante }\end{array}$ & $\begin{array}{l}\text { O conhecimento que o Sebrae oferece } \\
\text { aumenta decisivamente a chance de sucesso } \\
\text { de um negócio }\end{array}$ \\
\hline $\begin{array}{l}\text { porque é quem mais } \\
\text { entende de pequenos } \\
\text { negócios }\end{array}$ & $\begin{array}{l}\text { Especialistas em } \\
\text { pequenos negócios }\end{array}$ & $\begin{array}{l}\text { O Sebrae é o maior especialista em pequenas } \\
\text { empresas no Brasil }\end{array}$ \\
\hline $\begin{array}{l}\text { e possui a maior rede de } \\
\text { atendimento do país. }\end{array}$ & Está em todo lugar & $\begin{array}{l}\text { Quando eu preciso, o Sebrae está sempre por } \\
\text { perto, disponível }\end{array}$ \\
\hline
\end{tabular}

Fonte: SEBRAE, Serviço Brasileiro de Apoio às Micro e Pequenas Empresas.

Posicionamento de marca Sebrae: status 2015. Brasília: SEBRAE, 2015.

A entidade atua em diversas frentes: em contato direto com o empreendedor, capacitando-o para a gestão do seu negócio por meio de cursos, consultorias, publicações, palestras etc.; nas esferas política e burocrática, em busca de redução da carga tributária, ampliação de acesso a linhas de crédito e a novos mercados, inclusive para exportação; e, por 
fim, no incentivo à inovação e à tecnologia voltada para os pequenos negócios (SEBRAE, 2013a).

De acordo com o Global Entrepreneurship Monitor (GEM) de 2012, mais de 30\% dos brasileiros estavam envolvidos com atividades empreendedoras. Dez anos antes, em 2002, essa taxa era de 20,9\%. O crescimento expressivo do empreendedorismo no Brasil é apenas um dos fatores que demonstram a relevância do tema, tanto econômica, quanto socialmente (IBQP; SEBRAE, 2012, p. 10 e 11), já que os pequenos negócios participam ativamente do cenário produtivo brasileiro. São mais de seis milhões de estabelecimentos que correspondem a 99\% das empresas do país e que empregam sete milhões de trabalhadores com carteira assinada (DIEESE; SEBRAE, 2012, p. 27 e 29). Para validar a representatividade da população brasileira nos resultados da pesquisa, foram realizadas 10 mil entrevistas, duas mil por região, com brasileiros entre 18 e 64 anos,

O Sebrae possui 6 públicos prioritários: potencial empreendedor, potencial empresário, microempreendedor individual, microempresa, empresa de pequeno porte e produtor rural. Antes de detalhar cada um desses públicos, no entanto, é importante destacar a diferenciação que o Sebrae faz entre os termos empreendedor e empresário, utilizados muitas vezes como sinônimos. Empreendedor é o indivíduo que possui o desejo de se engajar ou já é engajado em atividade empreendedora, formal ou informal. Já o empresário é aquele indivíduo engajado em atividade empreendedora formal. Portanto, todo empresário é empreendedor, porém nem todo empreendedor é empresário, como explicitado na figura 1.

Figura 1 - Diferenciação feita pelo Sebrae entre os termos empreendedor e empresário

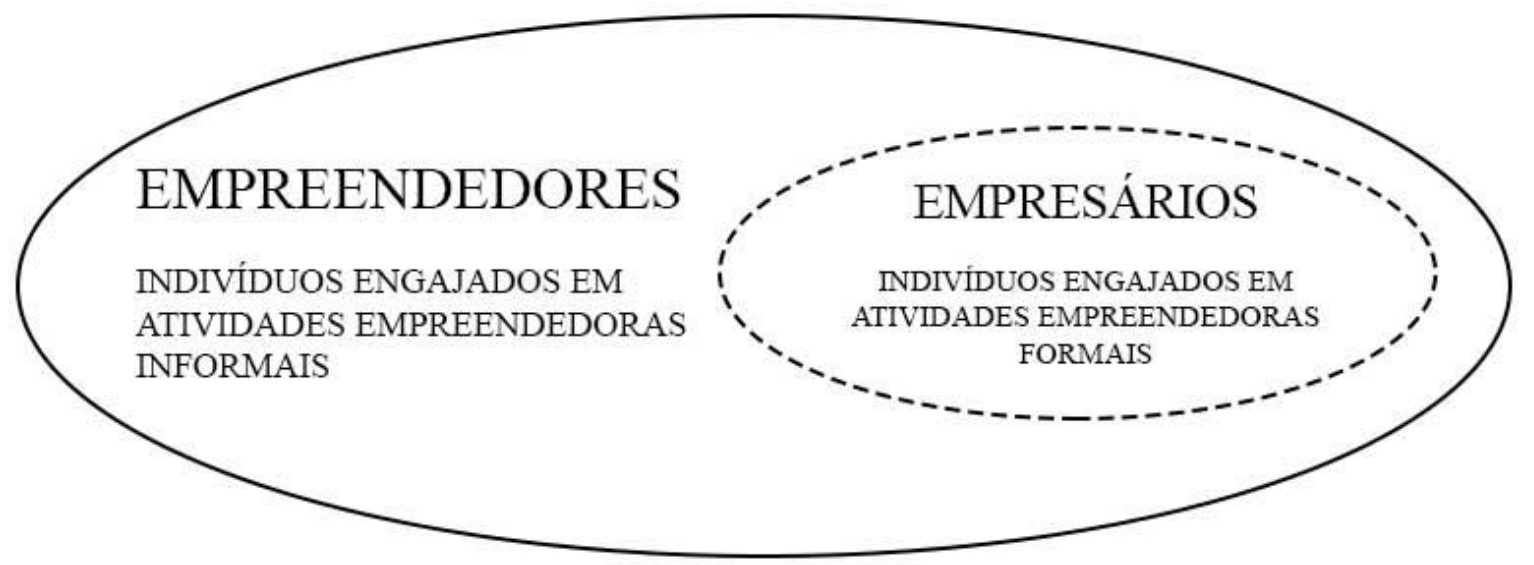

Fonte: elaborado pela autora

Assim, o Sebrae considera o público denominado potencial empreendedor como a sociedade em geral. Em outras palavras, aqueles indivíduos que poderão, um dia, transformar- 
se em empresários, mas que, no momento, não desejam e não estão engajados em atividade empreendedora. Dentro desse perfil, o Sebrae trabalha principalmente com jovens universitários. O potencial empresário, por sua vez, é o indivíduo já engajado em atividade empreendedora, porém em caráter informal. A diferenciação entre o microempreendedor individual, a microempresa e a empresa de pequeno porte é feita por faixa de faturamento dos negócios. Já produtores rurais são definidos como pessoas físicas que exploram atividades agrícolas ou pecuárias nas quais não sejam alteradas a composição e as características do produto in natura, também delimitados por faturamento (SEBRAE, 2012a). A seguir, a tabela 2 resume a segmentação de público do Sebrae:

Tabela 2 - Segmentação do público-alvo do Sebrae

\begin{tabular}{|c|c|}
\hline PÚBLICO & DETALHAMENTO \\
\hline $\begin{array}{l}\text { Potencial } \\
\text { empreendedor }\end{array}$ & Sociedade em geral, não engajada em atividade empreendedora. \\
\hline Potencial empresário & Indivíduo engajado em atividade empreendedora informal. \\
\hline $\begin{array}{l}\text { Microempreendedor } \\
\text { Individual (MEI) }\end{array}$ & $\begin{array}{l}\text { Empresário que fatura anualmente até } \mathrm{R} \$ 60.000,00 \text { (sessenta mil reais); é } \\
\text { optante pelo Simples Nacional e não tem participação em outra empresa } \\
\text { como sócio ou titular; possui no máximo um empregado que recebe um } \\
\text { salário mínimo ou o piso salarial da categoria profissional; e exerce uma } \\
\text { das atividades elencadas na Resolução 58/2009, atualizada pela Resolução } \\
78 / 2010 \text {, de acordo com a Lei Complementar } 128 / 2008 \text {, alterada pela Lei } \\
\text { Complementar 139/2011. }\end{array}$ \\
\hline Microempresa (ME) & $\begin{array}{l}\text { Empresas de origem brasileira, que possuam natureza jurídica compatível } \\
\text { com as atividades mercantis e faturem, anualmente, valor menor ou igual a } \\
\mathrm{R} \$ 360.000,00 \text { (trezentos e sessenta mil reais). }\end{array}$ \\
\hline $\begin{array}{l}\text { Empresa de Pequeno } \\
\text { Porte (EPP) }\end{array}$ & $\begin{array}{l}\text { Empresas de origem brasileira, que possuam natureza jurídica compatível } \\
\text { com as atividades mercantis e faturem, anualmente, mais de } \mathrm{R} \$ 360.000,00 \\
\text { (trezentos e sessenta mil reais) e não mais de } \mathrm{R} \$ 3.600 .000,00 \text { (três milhões } \\
\text { e seiscentos mil reais). }\end{array}$ \\
\hline Produtor rural & $\begin{array}{l}\text { Pessoas físicas que explorem atividades agrícolas ou pecuárias, nas quais } \\
\text { não sejam alteradas a composição e as características do produto "in } \\
\text { natura", que faturem até R\$ } 3.600 .000,00 \text { (três milhões e seiscentos mil } \\
\text { reais) por ano e que possuam inscrição estadual de produtor. Soma-se a esse } \\
\text { grupo o dos pescadores com registro no Ministério da Pesca. }\end{array}$ \\
\hline
\end{tabular}

Fonte: SEBRAE, Serviço Brasileiro de Apoio às Micro e Pequenas Empresas.

O público-alvo do Sebrae. Série Estudos e Pesquisas. Brasília: SEBRAE, 2012a. 
O Sistema Sebrae está presente em todo o território nacional, com mais de 700 pontos de atendimento. Sua atuação é descentralizada e cada estado conta com uma sede na capital e postos de atendimento no interior. A administração estadual é independente em diversos aspectos: de contratação de funcionários e desenvolvimento de produtos e serviços a investimentos em comunicação. As atividades do Sistema são fiscalizadas pela Controladoria Geral da União (CGU) e pelo Tribunal de Contas da União (TCU).

O orçamento do Sistema Sebrae é composto, principalmente, por um tipo de tributo, denominado contribuição social, que incide sobre as folhas de pagamento de médias e grandes empresas. Esse é, inclusive, tema polêmico, gerador de diversos processos por inconstitucionalidade, visto que as empresas que contribuem efetivamente para a manutenção do Sebrae não fazem parte de seu público-alvo e não são, assim, beneficiadas diretamente pela sua existência. O Sebrae Nacional, situado em Brasília, distribui anualmente, entre os estados, a verba repassada pelo governo federal. Suas atividades diferenciam-se das dos demais estados por serem de abrangência nacional, em especial as articulações políticas e as ações de comunicação.

Essas são fruto da relação entre o Sebrae e as agências publicitárias licitadas pela entidade, o que permite a criação, produção e veiculação de materiais de comunicação de abrangência nacional, entre eles: campanhas televisionadas, anúncios em revistas, jornais, cinema e mobiliário urbano, spots de rádio e ações online, incluindo hotsites de campanhas, e comunicação interativa em grandes portais como o YouTube e o Facebook. Entre 2009 e 2014, período determinado para a realização da pesquisa, duas agências de publicidade de grande porte dividiam a conta publicitária do Sebrae Nacional: Lew’LaralTBWA e Giacometti. Em junho de 2013, a agência Nova/SB também passou a responder pela conta. A Unidade de Marketing e Comunicação (UMC) realiza a gestão desse e de outros contratos. Sua equipe planeja os investimentos de acordo com as diretrizes estratégicas e prioridades do Sistema Sebrae e também a partir de informações geradas por pesquisas de mercado. Essas, normalmente, sobre hábitos de consumo de mídia, ou seja, hábitos de consumo de comunicação de massa.

Composta por um gerente, um gerente adjunto e 23 funcionários, a UMC possui 5 profissionais alocados no núcleo de publicidade, dos quais três trabalham especificamente com publicidade externa, sendo responsáveis pelas campanhas criadas para o microempreendedor individual. Além do núcleo de publicidade, a unidade é dividida em outros quatro grupos: o núcleo administrativo, o núcleo de patrocínio, o núcleo de marketing e o núcleo de imprensa. 
Essa configuração foi averiguada em março de 2015, podendo ter havido mudanças posteriormente.

A comunicação do Sebrae obedece à segmentação de público da entidade, criando e veiculando campanhas de acordo com demandas internas que surgem tanto das áreas de articulação institucional, quanto das áreas técnicas, responsáveis por produtos e serviços. Os principais aspectos considerados no planejamento de publicidade são, além dos diferentes públicos atendidos, os programas nacionais e as metas mobilizadoras. Os programas nacionais são um conjunto de projetos e ações que direcionam a atuação do Sistema Sebrae para o cumprimento de seus objetivos estratégicos. Já as metas mobilizadoras surgiram em 2009 e "têm por finalidade especificar, quantificar, indicar o foco, as áreas e projetos prioritários" da entidade a todos os seus colaboradores, dirigentes e parceiros. As metas são nacionais e são revisadas anualmente (SEBRAE, 2009, p. 10).

Este trabalho estabelece como fonte para a investigação a publicidade veiculada pelo Sebrae Nacional, especificamente aquela direcionada ao microempreendedor individual. Isso ocorre tanto pelo fato de o Sebrae Nacional ser o ambiente de trabalho da pesquisadora e, portanto, o gerador da inquietação que levou à estruturação da pesquisa, quanto pela própria abrangência nacional de sua comunicação, o que, acredita-se, enriquecerá a discussão.

\subsection{O microempreendedor individual}

Dentre os seis públicos prioritários do Sebrae, o microempreendedor individual é o foco deste trabalho. Para justificar essa escolha e dar continuidade à construção do cenário de pesquisa, é necessário apresentar esse público de maneira detalhada.

O microempreendedor individual surge a partir da criação da Lei Geral da Micro e Pequena Empresa,

\footnotetext{
sancionada em dezembro de 2006, pelo presidente Luiz Inácio Lula da Silva, [...] destinada a criar um ambiente favorável ao florescimento e ao desenvolvimento dos pequenos negócios no Brasil. Para muitos, foi o estatuto mais eficaz já concebido para estimular a vocação empreendedora do povo brasileiro, combater os efeitos paralisantes da burocracia e oferecer condições favoráveis à formalização de empreendimentos (SEBRAE, 2012b, p. 73 e 74).
}

Em julho de 2009, um capítulo da Lei Geral foi regulamentado pelo Congresso Nacional e instituiu a figura jurídica do microempreendedor individual (MEI), criado "com o objetivo de formalizar os trabalhadores que atuam por conta própria” (Id., p. 85). A criação do MEI é uma 
das principais políticas da lei, da qual também fazem parte desburocratização, desoneração tributária, acesso a mercados, crédito, inovação e tecnologia, acesso à justiça, entre outras.

As condições para que uma empresa seja enquadrada na categoria MEI são: ter faturamento anual de até 60 mil reais; possuir no máximo dois participantes (um sócio, ou dois sócios, ou ainda um sócio e um funcionário); não haver envolvimento do dono do negócio em outra atividade empresarial; e desenvolver atividades permitidas pelo Simples Nacional, regime tributário diferenciado e simplificado direcionado a micro e pequenas empresas.

O cadastro como microempreendedor individual pode ser feito pela internet, por meio do Portal do Empreendedor (www.portaldoempreendedor.gov.br) ou, ainda, junto a contadores, indicados tanto no portal, quanto no site da Fenacon, Federação Nacional das Empresas de Serviços Contábeis e das Empresas de Assessoramento, Perícias, Informações e Pesquisas (www.fenacon.org.br).

Os benefícios de ser um MEI, ou seja, ter cidadania empresarial, são: realizar a formalização de maneira simplificada, rápida e gratuita; possuir um número de cadastro nacional de pessoa jurídica (CNPJ), podendo assim emitir notas fiscais e ter acesso a crédito; ter carga tributária reduzida em comparação a outros tipos de empreendimentos e ter acesso aos benefícios previdenciários (aposentadoria por idade, aposentadoria por invalidez, auxíliodoença, licença maternidade, pensão por morte e auxílio reclusão). Além disso, o microempreendedor individual conta com o apoio e a capacitação de entidades como o Sebrae para ajudá-lo na gestão de seu negócio.

Para ter acesso a esses benefícios, o microempreendedor individual precisa pagar mensalmente o carnê DAS (documento de arrecadação simplificada) e, anualmente, entregar à Receita Federal o DASN-SIMEI (declaração anual do Simples Nacional do MEI). Os impostos de pagamento obrigatório para o microempreendedor individual são o INSS (no valor de 5\% do salário mínimo vigente) e, no caso das empresas de serviços, R \$ 5,00 (cinco reais) de ISS (imposto sobre serviços) ou, para as atuantes no comércio e indústria, R \$ 1,00 (um real) de ICMS (imposto sobre circulação de mercadorias e serviços).

Três anos depois da institucionalização, em julho de 2012, o Brasil já contava com 2,5 milhões de novas empresas legalizadas (SEBRAE, 2012b, p. 85). Ainda em 2012, esse foi o segmento de público que mais procurou atendimento do Sebrae: dos mais de 1,5 milhão de atendimentos realizados, $48 \%$ eram de microempreendedores individuais (SEBRAE, 2012, p. 18). Destaca-se também o fato de o MEI pertencer majoritariamente à chamada nova classe $C$, público que "saiu da pobreza e passou a integrar plenamente o universo do consumo, formando 
uma nova Classe Média que se tornou protagonista de um mercado interno crescente" (MEIRELLES, 2012, p. 3).

Atualmente, esse segmento da população responde por 55,2\% dos empreendedores formais no Brasil (ASN, 2013). É um público relativamente jovem, com idade entre 31 e 40 anos, sendo 53\% homens e 47\% mulheres (SEBRAE, 2013). Mais de $40 \%$ dos microempreendedores individuais possui ensino médio ou técnico completo e tem negócio estabelecido na região sudeste brasileira (Id.). Atuam principalmente nos setores de comércio e serviços (SEBRAE, 2012, p. 26 e 27), nos quais a principal atividade exercida é o varejo de artigos de vestuário ou acessórios e cabeleireiros, respectivamente. Na construção civil, a atividade mais comum são as obras de alvenaria. Já na confecção, são as peças de vestuário. Tratam-se de atividades que atendem às demandas básicas de mercado e são, normalmente, de baixo valor agregado.

Mais de $40 \%$ de todos os microempreendedores individuais estiveram por mais de 10 anos na informalidade. É interessante notar que os benefícios previdenciários não foram o principal motivador da formalização, mas sim a oportunidade de terem seu próprio CNPJ. Para $68 \%$ do público, a formalização proporcionou aumento no faturamento, enquanto $78 \%$ obteve melhores condições de compra junto a fornecedores. Para $84 \%$ dos MEI, há perspectiva de crescimento do negócio e 79\% do público recomenda a formalização (SEBRAE, 2013).

Ao todo, quatrocentos e setenta e uma atividades são permitidas para atuação como microempreendedor individual (SEBRAE, 2012d). A lista completa das categorias pode ser acessada no Portal do Empreendedor: www.portaldoempreendedor.gov.br.

\subsection{O impacto da criação do MEI}

No início de 2009, pouco antes da regulamentação e instituição da figura do MEI, o Sebrae realizou uma pesquisa qualitativa com o objetivo de avaliar o impacto da possível mudança na legislação para empreendedores que teriam a oportunidade de se formalizar. Além de levantar essas informações, outras questões relevantes sobre esse público foram abordadas. A metodologia de pesquisa consistiu na realização de 10 grupos de discussão, em cinco capitais brasileiras (Belém, Recife, Goiânia, São Paulo e Porto Alegre), entre os dias 6 e 12 de fevereiro daquele ano. Categorias de negócio que participaram dos grupos de discussão estão descritas na tabela 3. Segundo o relatório de pesquisa, todos os participantes eram pertencentes às classes sociais C2/D e tinham entre 25 e 45 anos de idade. De acordo com o relatório de pesquisa, a determinação da classe social dos participantes foi realizada com base em dois fatores: a 
escolaridade e o Critério de Classificação Econômica Brasil. Segundo o CCEB de 2009, que utiliza dados do levantamento sócio econômico do IBOPE dos anos 2006 e 2007, a renda média familiar - valor bruto em reais - das classes C2 e D era de, respectivamente, 849/861 e 549/573 (ABEP, 2009, p. 3). Foram conduzidos dois grupos em cada cidade: um somente com mulheres e outro somente com homens.

Tabela 3 - Categorias de negócio participantes dos grupos de discussão

\begin{tabular}{|c|c|c|c|c|}
\hline \multicolumn{5}{|c|}{ CATEGORIAS DE NEGÓCIO } \\
\hline Artesão & Cabeleireiro & Camelô & Carpinteiro & $\begin{array}{l}\text { Confecciona e } \\
\text { vende bijuterias }\end{array}$ \\
\hline Conserta celular & Costureira & Cozinheira & Diarista & Eletricista \\
\hline Encanador & Faxineira & $\begin{array}{l}\text { Fornecedor de } \\
\text { marmitex }\end{array}$ & Lavadeira & Manicure \\
\hline Marceneiro & Massagista & Motoboy & Motorista & Pedreiro \\
\hline Pintor & Pipoqueiro & $\begin{array}{l}\text { Polidor de } \\
\text { automóveis }\end{array}$ & $\begin{array}{c}\text { Promotora de festas } \\
\text { e eventos }\end{array}$ & Salgadeira \\
\hline Serralheiro & Sorveteiro & $\begin{array}{l}\text { Técnico em } \\
\text { informática }\end{array}$ & $\begin{array}{c}\text { Vendedor de água } \\
\text { de coco }\end{array}$ & Vendedor de bolos \\
\hline $\begin{array}{c}\text { Vendedor de } \\
\text { cachorro quente }\end{array}$ & $\begin{array}{l}\text { Vendedor de } \\
\text { churros }\end{array}$ & $\begin{array}{l}\text { Vendedora de } \\
\text { cosméticos }\end{array}$ & Vendedor de frutas & $\begin{array}{l}\text { Vendedora de } \\
\text { pastel }\end{array}$ \\
\hline $\begin{array}{l}\text { Vendedora de } \\
\text { sucos }\end{array}$ & $\begin{array}{l}\text { Vendedora de } \\
\text { salgados }\end{array}$ & & & \\
\hline
\end{tabular}

Fonte: SÍNTESE, Pesquisa e Análise. Pesquisa qualitativa Sebrae. Brasília, SEBRAE, 2009, p. 2.

Em relação ao perfil do público-alvo, a pesquisa mostrou que o empreendedor informal se autodenominava autônomo, e não microempresário. Outro aspecto relevante para a comunicação com esse público é o fato de que o termo empreendedor não era compreendido pela maior parte deles. E, mesmo aqueles que conheciam o significado do termo o percebiam como sofisticado e não associavam suas atividades empreendedoras ao conceito (SÍNTESE, 2009, p. 3). Como o termo carrega também o significado de empresário, esse público acabava não se reconhecendo como tal. Foi nesse cenário de significação complexa que surgiu o conceito de microempreendedor individual (Id., p. 3).

Além de não compreender o conceito de empreendedor e não se identificar como potencial empresário, significados que são trazidos à tona pela criação do microempreendedor 
individual, a pesquisa realizada mostrou também que a sigla MEI apresenta conotação negativa para o público. Durante os grupos focais, a menção da sigla gerou, primeiramente, risos e deboches. Foi associada à palavra "meio", com sentido de metade, e o a sigla utilizada para emendar palavras pejorativas como "endividado" e "enrolado". Passado o deboche inicial, instaurou-se o sentimento de diminuição da categoria, e comentários como "meio empresário", "meio empreendedor", “já está colocando nós pela metade” e "por que já está deixando a gente de lado" surgiram durante a dinâmica (Ibid., p. 4).

Quanto à nova legislação, que seria regulamentada poucos meses depois da realização da pesquisa, as reações foram positivas. No entanto, o relatório de pesquisa chama atenção, de modo pertinente, para o fato de que:

é difícil ser explicitamente crítico a uma proposta com características tão "politicamente corretas" (facilitação da formalização da atividade, acesso aos benefícios previdenciários, possibilidade de acesso a crédito etc.) e cujo custo é considerado acessível/justo (Ibid., p. 6).

Mesmo assim, certa desconfiança demonstrada pelo público é resultante da falta de credibilidade no governo federal. Os participantes da pesquisa afirmaram temer o aumento dos impostos para o MEI após a formalização, e também temem que a regulamentação da lei não "vá pra frente", como já aconteceu com outros programas e projetos que beneficiavam a categoria, como o Banco do Povo e oportunidades de microcrédito (Ibid., p. 8). Além disso, o empreendedor mostra-se desconfortável com o acesso do governo a dados como faturamento do negócio, demonstrando mais uma vez que o governo não é visto como aliado do público.

Todas essas informações são de extrema importância e devem ser levadas em consideração quando se trata da criação de campanhas publicitárias para esse público. A figura jurídica já existe, o governo federal já instituiu o nome microempreendedor individual e sua sigla, MEI. O Sebrae não pode fugir ao uso dessa nomenclatura. Diante disso, como trabalhar essa comunicação, uma vez que o conceito de empreendedor é pouco conhecido, e quando é conhecido não é associado ao microempreendedor individual? E quando sua sigla provoca reações negativas?

A primeira tentativa de minimizar essas dificuldades foi modificar ligeiramente o termo nas peças de comunicação, o que ocorreu até o ano de 2012. No lugar de microempreendedor individual e MEI, era utilizada a expressão empreendedor individual e a sigla EI. Durante a análise realizada nesta investigação, será possível ver anúncios com ambas as denominações e, durante as entrevistas, discussões sobre a efetividade de cada uma delas. 
Outro desafio encontrado que merece ser apontado é a possibilidade de o público-alvo associar e até mesmo confundir o Sebrae com o governo federal, uma vez que, após a instituição da figura jurídica do MEI, o Sebrae passou a incentivar a formalização daqueles empreendedores que se enquadravam nas condições estabelecidas pela legislação vigente. Ao fomentar a formalização, além de cumprir sua missão, o Sebrae busca ampliar sua base de clientes, uma vez que seus produtos e serviços estão disponíveis apenas para empreendimentos formalizados e o primeiro passo no atendimento de um empreendedor informal é justamente a formalização. Assim, desde 2009, o Sebrae Nacional vem periodicamente criando e veiculando campanhas publicitárias direcionadas a esse público.

\subsection{O SEI - Sebrae Empreendedor Individual}

Desde a sua constituição, o Sebrae vem criando produtos e serviços para atender as necessidades de gestão do empresariado brasileiro. Quando o microempreendedor individual foi instituído, em 2009, não havia nenhum curso, oficina ou consultoria específicos para o atendimento a esse novo público que, naquele momento, tornara-se um empreendedor formalizado. As soluções de atendimento existentes logo se mostraram insuficientes para suprir necessidades tão particulares quanto àquelas do MEI, público que crescia a cada dia e procurava mais e mais o atendimento do Sebrae.

Assim, em 2011, foi criado um conjunto de soluções para atender justamente aos negócios dos microempreendedores individuais, auxiliando-os na gestão de seus empreendimentos: o SEI, Sebrae Empreendedor Individual. São, ao todo, 9 oficinas temáticas, enumeradas na tabela 4 :

Tabela 4 - Oficinas SEI (continua)

\begin{tabular}{|l|l|}
\hline \multicolumn{1}{|c|}{ OFICINA SEI } & \multicolumn{1}{c|}{ DESCRIÇÃO } \\
\hline \hline SEI Vender & $\begin{array}{l}\text { Saiba calcular o valor ideal de seu produto ou serviço e alcançar mais } \\
\text { clientes }\end{array}$ \\
\hline SEI Comprar & Aprenda a negociar com fornecedores: qualidade, preço e prazo \\
\hline SEI Planejar & $\begin{array}{l}\text { Identifique oportunidades, conheça ferramentas, melhore o } \\
\text { desempenho }\end{array}$ \\
\hline SEI Controlar meu dinheiro & Princípios básicos de gestão fazem o dinheiro da empresa render \\
\hline
\end{tabular}


Tabela 4 - Oficinas SEI (conclusão)

\begin{tabular}{|l|l|}
\hline SEI Formar preço & $\begin{array}{l}\text { Como saber exatamente o quanto o seu produto ou serviço custa? } \\
\text { Aqui você aprende a encontrar o preço certo para manter o seu } \\
\text { negócio sem perder a lucratividade }\end{array}$ \\
\hline SEI Empreender & Desenvolva o empreendedor que há em você e prospere \\
\hline SEI Unir forças para melhorar & Entenda as vantagens de empreender em grupo \\
\hline SEI Administrar & $\begin{array}{l}\text { Aprenda a gerir o seu negócio e saiba como traçar o caminho do seu } \\
\text { negócio em direção ao sucesso }\end{array}$ \\
\hline SEI Crescer & $\begin{array}{l}\text { Como saber se está na hora de subir o próximo degrau? O SEI } \\
\text { Crescer auxilia você na tomada de decisão sobre permanecer como } \\
\text { Microempreendedor Individual (MEI) ou tornar-se Microempresa } \\
\text { (ME) }\end{array}$ \\
\hline
\end{tabular}

Fonte: Portal Sebrae. Disponível em: <http://www.sebrae.com.br/sites/PortalSebrae/sebraeaz/Com-assoluções-SEI-você-aprende-a-cuidar-bem-de-seu-negócio>. Acesso em: Abr. 2015.

Objetivando disseminar esses conhecimentos ao maior número possível de microempreendedores individuais, o Sebrae disponibiliza o conteúdo das oficinas de diversas maneiras, todas gratuitas. O MEI pode se inscrever em um curso presencial, ministrado em sala de aula com instrutores treinados, pode ainda cursar as oficinas pela internet; retirar cartilhas com conteúdo do SEI nos pontos de atendimento do Sebrae ou baixá-las em formato .pdf no site da entidade; cursar as oficinas por meio de tele aula, com apostilas e DVDs ou, ainda, receber o conteúdo dos cursos no celular ou em formato de audiolivro.

Assim, a partir da apresentação do Sebrae, do contexto em que foi criado o microempreendedor individual e dos produtos e serviços que a entidade disponibiliza para esse público, é possível continuar o desenvolvimento da pesquisa com a apresentação da fundamentação teórica que norteia este trabalho. 


\section{II - FUNDAMENTAÇÃO TEÓRICA}

\section{A COMPLEXIDADE DO FENÔMENO COMUNICACIONAL}

\subsection{O processo comunicacional}

Para dar início à abordagem do tema, é preciso conceituar o termo comunicação, com o objetivo de esclarecer sob qual perspectiva a pesquisa será realizada, uma vez que o conceito permite inúmeras interpretações. Segundo Bergström (2009, p. 220), a palavra deriva do latim communicare e significa "transformar alguém em participante", visto que não há comunicação sem a participação de dois ou mais indivíduos. Já Martino (2001, p. 13) traz o termo communicatio e o fraciona em: co, simultâneo, munis, encarregado de e tio, atividade, o que é entendido pelo autor como "atividade realizada conjuntamente". Em resumo,

comunicar tem o sentido de tornar similar e simultânea as afecções presentes em duas ou mais consciências. Comunicar é simular a consciência de outrem, tornar comum (participar) um mesmo objeto mental (sensação, pensamento, desejo, afeto) (Id., p. 23).

O processo comunicacional pode ser definido, de forma simplificada, como a transmissão de uma mensagem codificada sobre um referente, de um emissor a um receptor, por meio de um canal específico (figura 2). O código em que a mensagem é transmitida deve ser conhecido tanto pelo emissor, quanto pelo receptor, ou seja, ambos devem estar familiarizados com as convenções preestabelecidas para aquele código. Além disso, o canal deve ser acessível ao receptor, pois é o canal quem "carrega" a mensagem. Assim, seu principal objetivo é a transmissão completa e correta dessa mensagem, eliminando ou reduzindo os ruídos entre emissor e receptor (CHALHUB, 2006, p. 30). 
Figura 2 - Processo comunicacional

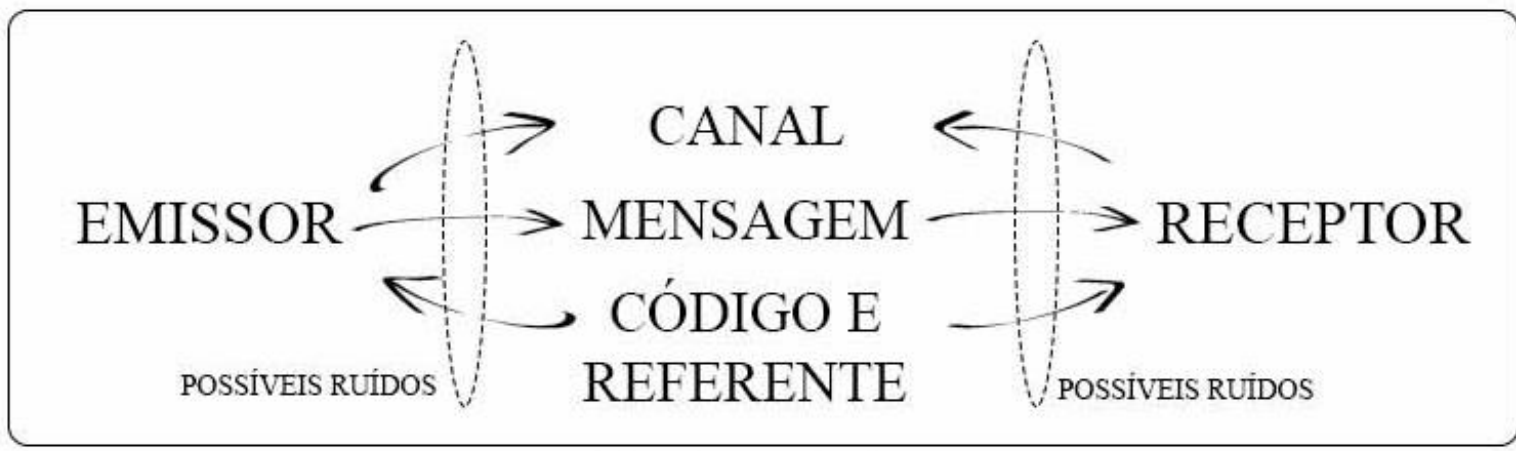

\section{CONTEXTO}

Fonte: CHALHUB, Samira, 1946-1998. Funções da linguagem. 12ª Edição. São Paulo: Ática, 2006., p. 30

A apresentação desse esquema simplificado é apenas o ponto de partida para a discussão do processo comunicacional. Atualmente, com o avanço da tecnologia e a multiplicação das maneiras de se comunicar, percebe-se uma multiplicação dos dois polos do processo: o do emissor e o do receptor. Em outras palavras, é possível identificar, cada vez mais facilmente, interações comunicacionais envolvendo grande quantidade de interlocutores, em especial aquelas que acontecem nas redes sociais da internet.

Note-se, também, que comunicação é diferente de informação. Enquanto a última faz referência ao conteúdo de uma mensagem dentro do processo comunicacional, a primeira traduz o processo como um todo, ou seja, com todos os seus elementos. Martino (2001, p. 17) resume a questão ao afirmar que informação é comunicação em potencial, pois pode ser codificada e armazenada pelo emissor para ser resgatada e reconvertida pelo receptor quando ambos estão situados em diferentes pontos no tempo e espaço. Assim, o processo comunicacional utiliza-se de informação, mas ela, por si só, não é suficiente para caracterizar o fenômeno. A informação é parte da comunicação. Para que uma comunicação aconteça é necessário mais do que apenas características comuns aos indivíduos que participam do processo. $\mathrm{O}$ autor traduz bem essa questão ao exemplificar: "não é porque as folhas das árvores são verdes e a esmeralda também é verde, que elas se comunicam" (Id., p. 14).

No âmbito deste trabalho, o conceito de comunicação vai além e corresponde, de maneira objetiva, como "um processo de transmissão que tem como objetivo a persuasão" (FRANÇA, 2001, p. 17) denominou, persuasão esta que objetiva a realização de determinada ação ou adoção de um comportamento específico pelo receptor. Em outras palavras, uma relação intencional entre, pelo menos, dois indivíduos, onde intenção pode ser entendida como 
um compartilhamento de consciências, um processo em que o emissor tenta imprimir a mensagem que está em sua consciência na mente do receptor dessa mesma mensagem.

No que se refere ao canal, os meios de comunicação de massa e seus dispositivos técnicos - como televisão, jornal, revista, internet etc. - são os canais que dão suporte à mensagem transmitida. Toda mensagem exige um suporte físico para ser transmitida, ou seja, "em alguma estrutura física os sinais organizados devem repousar" (CHALHUB, 2005, p. 12).

A seguir são detalhados dois aspectos importantes na composição do cenário dessa investigação e que estão ligados diretamente ao código das mensagens publicitárias: as possibilidades criadas pelas imagens e pelas funções da linguagem no processo comunicacional.

\subsubsection{As imagens}

O mundo é, hoje, povoado por imagens cada vez mais numerosas, diversificadas e intercambiáveis (AUMONT, 2007, p. 14). Mas, afinal, o que é uma imagem? Joly (2012, p. 19) expõe a dificuldade em definir o termo, uma vez que a palavra imagem é utilizada em inúmeros contextos e com significados distintos, e a caracteriza como "algo que se assemelha a outra coisa" (Id., p, 38, grifo da autora), destacando sua capacidade de confundir-se com aquilo que representa. Flusser (2013, p. 152) define imagem como "uma mensagem: ela tem um emissor

e procura por um receptor", ponte entre o sujeito e o mundo objetivo. É, ainda, uma superfície que poderá ser percebida "num lance de olhar" ou analisada de forma mais detalhada (Id., p. 131).

Nöth e Santaella (1998, p. 30) recorrem à psicologia cognitiva para definir imagem: uma reprodução de algo vivido, ou seja, que não está presente, que pode representar algum aspecto do mundo real, tangível, ou ter um fim em si mesma, no caso de figuras abstratas ou formas coloridas (Id., p. 37). Além disso, os autores dividem as imagens em dois grupos: o primeiro composto por representações visuais concretas, tais como "desenhos, pinturas, gravuras, fotografias e as imagens cinematográficas, televisivas", e o segundo formado pelas imagens mentais. Piaget (Apud ibid., p. 30), por sua vez, trabalha imagens mentais chamadas por ele de imagens interiores e definidas como esquemas representativos de acontecimentos externos que, ao se interiorizarem, sofrem transformações.

Diante de tantas definições, é possível constatar a interdisciplinaridade dos estudos da imagem. Nöth e Santaella (Ibid., p. 13) afirmam, categoricamente, que não há tradição e nem "suporte institucional de pesquisa que lhe seja próprio. Uma ciência da imagem, uma 
imagiologia ou iconologia ainda está por existir”. No âmbito deste trabalho, será considerada a conceituação de Aumont (2007, p. 139). O autor define imagem como objeto do mundo que, como outros objetos, possui características físicas que a tornam perceptível. Imagens são criadas para figurarem em determinados meios que, portanto, definem como serão percebidas. "A imagem é também um meio de comunicação e de representação do mundo, que tem seu lugar em todas as sociedades humanas" (Id., p. 131).

Ao trazer informações visuais do mundo e para o mundo, a imagem tem por função causar impacto em quem a vê. Aumont (Ibid., p. 80) refere-se apenas ao impacto positivo da imagem ao afirmar que uma de suas funções é "agradar seu espectador". Porém, não se pode generalizar. Há imagens que chocam. Até mesmo as publicitárias, que em geral buscam provocar sensações de bem estar no público-alvo. Um exemplo disso são as fotos utilizadas em campanhas antitabagismo, antidrogas e contra a violência doméstica (figura 3).

Figura 3 - Anúncios da organização britânica Women's Aid alertam para a violência doméstica, em 2007
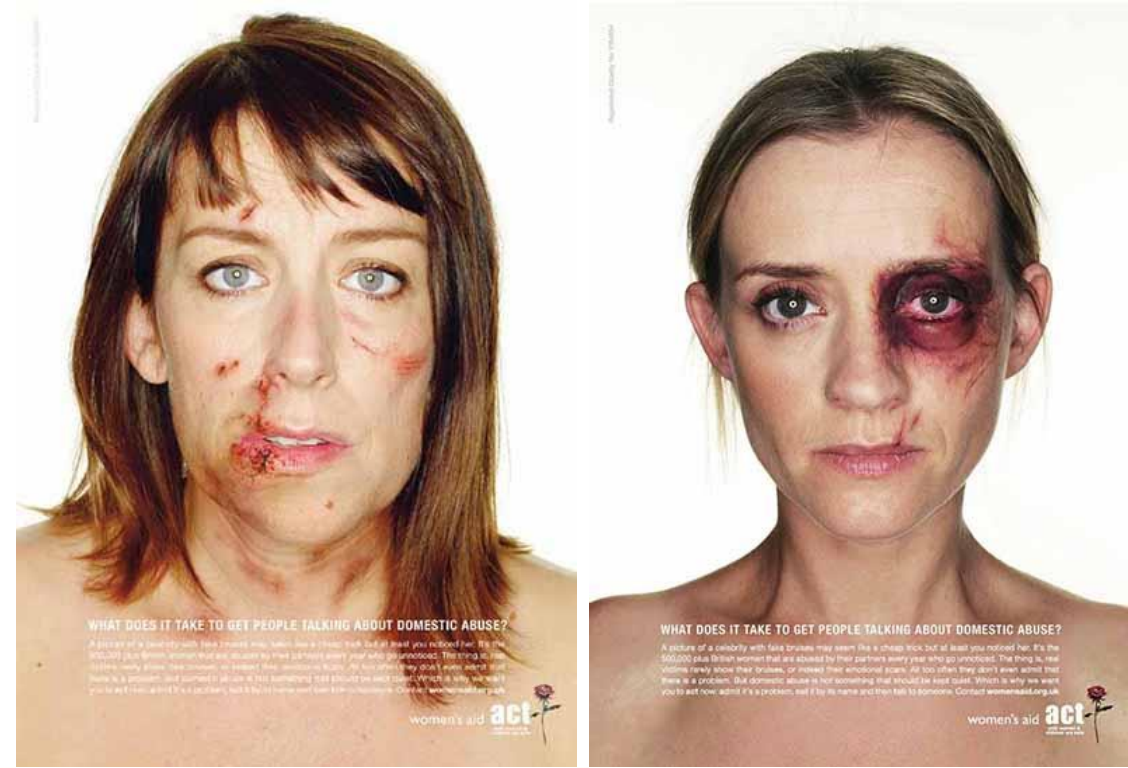

Fonte: Women's Aid. Women's Aid Campaigns.

Disponível em: 〈http://www.womensaid.org.uk/>. Acesso em: Set. 2014.

A imagem, portanto, deve contar uma história, apresentar um acontecimento, situar o espectador no tempo espaço para que ele interprete a mensagem corretamente - no caso da publicidade, como o anunciante deseja. Assim, a função da imagem é "evocar, querer dizer outra coisa que não ela própria, utilizando o processo da semelhança. Se a imagem é percebida como representação, isso quer dizer que a imagem é percebida como signo" (JOLY, 2012, p. 39). Em outras palavras, da relação que as imagens estabelecem entre mundo real e sujeito receptor da mensagem surge o fenômeno da representação. 
Segundo Aumont (2007, p. 181), a fotografia publicitária, tipo de imagem representativa em foco neste trabalho, tende a funcionar "como uma espécie de armadilha ideológica, já que implica um sujeito espectador que esteja prontamente disposto a aceitar a perspectiva como ferramenta legítima de representação [...] e a acreditar que a fotografia é mesmo um registro do real". Essa armadilha, no entanto, concretiza-se somente quando o espectador acredita que a imagem fotográfica representa o mundo real tal qual ele é, sem ressalvas. O consumo da fotografia publicitária, porém, acontece de maneira mais cautelosa. $\mathrm{O}$ espectador aceita que a imagem represente o real, ou uma possibilidade do real, num processo consciente de ilusão.

A consciência sobre a realidade representada pela fotografia é fundamental dentro da dinâmica da comunicação publicitária. É ingênuo acreditar que o público da mensagem recebe tal comunicação sem filtros, sem o mínimo de discernimento sobre a realidade construída pelo fotógrafo. No caso da publicidade, mais explícito ainda, uma realidade construída e adaptada para influenciar e persuadir de acordo com as necessidades do anunciante. Em outras palavras, a fotografia publicitária apresenta, de maneira perspicaz, uma segunda realidade que é sedutora em sua montagem e estética. Como afirmou Kossoy (2002, p. 42),

a produção da obra fotográfica diz respeito ao conjunto dos mecanismos internos do processo de construção da representação, concebido conforme uma certa intenção, construído e materializado cultural, estética/ideológica e tecnicamente, de acordo com a visão particular de mundo do fotógrafo.

A transformação da imagem fotográfica, no entanto, não se encerra aí. Após sua construção inicial, ou seja, a imagem captada pelo fotógrafo, há ainda modificações provenientes dos processos de editoração, denominados pós-produção. Incluem nesse processo aquelas alterações que visam a adaptação da imagem aos meios de comunicação de massa, no caso específico da publicidade (Id., p. 54). Finalmente, quando essa imagem chega ao públicoalvo, ela deve ser recebida conforme o desejo do anunciante. Retorna à discussão, portanto, o papel do receptor dentro do processo comunicacional e a sua capacidade de interpretar as mensagens recebidas.

Ao ser consumida, a imagem fotográfica transcende o fato ou momento que representa (Ibid., p. 46). Seu caráter polissêmico permite diversas interpretações, que variam de indivíduo para indivíduo. Essas interpretações, por sua vez, influenciam os comportamentos diante das imagens. Kossoy (Ibid., p. 44) explica que

a recepção da imagem subentende os mecanismos internos do processo de construção da interpretação, processo esse que se funda na evidência fotográfica e que é elaborado 
no imaginário dos receptores, em conformidade com seus repertórios pessoais culturais, seus conhecimentos, suas concepções ideológicas/estéticas, suas convicções morais, éticas, religiosas, seus interesses econômicos, profissionais, seus mitos.

Bergström (2009, p. 159), por sua vez, afirma que a imagem "fertiliza a imaginação do espectador" e, a partir deste efeito, ela é possuída por ele, resultando na maior dificuldade da comunicação visual: a interpretação, uma vez que há leituras diversas para as mesmas mensagens ou imagens. Essa dificuldade certamente não invalida todo o processo que visa à persuasão. $\mathrm{O}$ autor defende, inclusive, a generalização nas imagens fotográficas, ao afirmar que "uma imagem que move profundamente um receptor na direção correta com certeza fará o mesmo com os outros. O mais pessoal costuma também ser o mais universal” (Id., p. 160). Já Joly (2012, p. 40) afirma que existe, entre emissor e receptor, um mínimo de convenção sociocultural que possibilita a comunicação entre eles. Além disso,

a concepção da fotografia como uma forma de construção da realidade, e assim sujeita a interpretações subjetivas, tanto do produtor quanto do receptor da mensagem visual, não subtrai [...] a validade da Análise da Imagem como documento. Esse tipo de pesquisa se torna especialmente válido quando se trata da análise de imagens impressas em veículos de comunicação (COUTINHO, 2012, p. 332).

Em relação às imagens analisadas no presente trabalho, é importante designá-las como imagens icônicas, e não imagens mentais, ainda que haja correspondências e similaridades entre essas categorias imagéticas. Como afirma Joly (2012, p. 19), uma imagem denominada mental é aquela que possibilita ao indivíduo, quando lê ou ouve a descrição de um lugar, por exemplo, vê-lo quase como se estivesse naquele local. Em outras palavras, "uma representação mental é elaborada de maneira quase alucinatória, e parece tomar emprestadas suas características da visão".

Esse não é o caso das imagens analisadas neste trabalho, uma vez que a representação do microempreendedor individual se faz presente de maneira concreta por meio de imagens icônicas nas peças publicitárias criadas e veiculadas pelo Sebrae. Essas imagens possuem uma "relação analógica com aquilo que representam [...] Um desenho, uma foto, uma pintura figurativa, retomam as qualidades formais do seu referente: formas, cores e proporções que permitem o seu reconhecimento" (Id., p. 36 e 37).

Essas são premissas adotadas para a investigação proposta. Em suma, o que se busca no presente trabalho são as possibilidades de interpretação surgidas em contextos específicos, para um público determinado, separando o que é pessoal do que é coletivo (Ibid., p. 44). Cabe lembrar que percepção e interpretação, embora confundidas com frequência, são duas ações 
distintas. Bergström (2009) e Joly (2012) afirmam que a percepção leva à interpretação e, portanto, não são processos simultâneos. Perceber é reconhecer, enquanto interpretar é expressar o significado em uma mensagem.

Além do aspecto imagético presente no código da mensagem dentro do processo comunicacional, a discussão sobre o texto publicitário se mostra necessária e complementar no contexto da presente pesquisa. Para abordar essa questão, o referencial teórico utilizado neste trabalho inclui as funções da linguagem.

\subsubsection{As funções da linguagem}

As funções da linguagem apontam recursos utilizados pelo emissor para enfatizar determinados elementos do processo comunicacional e, consequentemente, direcionar a comunicação. O primeiro estudioso a propor um modelo para as funções da linguagem foi o psicólogo austríaco Karl Buhler. Para ele, havia as funções referencial, emotiva e conativa. O linguista russo Roman Jakobson, em seu ensaio "Linguística e poética", publicado em 1960, ampliou o modelo de Buhler e acrescentou mais três funções: fática, poética e metalinguística. Suas pesquisas contribuíram em diversas áreas do conhecimento, como a antropologia, a literatura, a gramática, a comunicação e até mesmo as investigações sobre distúrbios da fala. Neste trabalho, foi usada como referência a versão do trabalho de Jakobson traduzida para o português e publicada em 2003, pela editora Cultrix.

No campo da comunicação, Jakobson utilizou o diagrama do processo comunicacional como base para seus estudos sobre as funções da linguagem. O autor relaciona a ênfase dada pelo emissor a cada elemento do processo comunicacional à função da linguagem resultante de cada comunicação, conforme indicado na tabela 5. Em outras palavras, ele utiliza os elementos do processo comunicacional para identificar a função da linguagem predominante na mensagem. 
Tabela 5 - Ênfase no fator determina a função da linguagem

\begin{tabular}{|l|l|}
\multicolumn{1}{|c|}{$\begin{array}{c}\text { FATOR DO PROCESSO } \\
\text { COMUNICACIONAL }\end{array}$} & \multicolumn{1}{c|}{\begin{tabular}{c}
\multicolumn{1}{c|}{ FUNÇÃO DA LINGUAGEM } \\
PREDOMINANTE
\end{tabular}} \\
\hline \hline Referente & Função referencial \\
\hline Emissor & Função emotiva \\
\hline Receptor & Função conativa \\
\hline Canal & Função fática \\
\hline Mensagem & Função poética \\
\hline Código & Função metalinguística \\
\hline
\end{tabular}

Fonte: CHALHUB, Samira. Funções da linguagem. 12ª Edição. São Paulo: Ática, 2006, p. 6

A partir da construção desse panorama, é possível conceituar cada uma das funções da linguagem para identificá-las posteriormente no corpus da pesquisa. Para isso serão utilizados, além dos estudos de Jakobson, as contribuições de Chalhub e Sandmann. Ainda que as definições apresentadas privilegiem a linguagem escrita, as funções da linguagem são bastante utilizadas em estudos sobre comunicação, sejam elas verbais ou não (JOLY, 2012, p. 56).

A primeira função apresentada, a referencial, é aquela com ênfase no referente (conteúdo) da mensagem e que produz informações denotativas, ou seja, mensagens assertivas, precisas e ditas de forma clara para o receptor (CHALHUB, 2006, p. 11 e 12). É predominante em noticiários, documentos históricos, laudos médicos etc. A linguagem científica e técnica também apresenta, predominantemente, a função referencial. O verbo está normalmente, na terceira pessoa, e utiliza-se bastante a voz passiva. Sandmann $(2014$, p. 25) resume a função referencial ao afirmar que "os fatos estão em evidência e devem convencer o destinatário da mensagem e eventualmente levá-lo a agir”. Jakobson (2003, p. 123) afirma que a função referencial é, geralmente, a mais utilizada em textos formais, embora o pesquisador deva estar atento para identificar outras funções adicionais presentes na mensagem.

A função emotiva, por sua vez, é centrada no emissor, utiliza a primeira pessoa verbal e é marcada por interjeições e adjetivos, elementos da linguagem que "implicam, sempre, uma marca subjetiva de quem fala, no modo como fala" (CHALHUB, 2006, p. 18). Para Jakobson (2003, p. 124), o uso de interjeições é uma das mais importantes manifestações da função emotiva, também chamada por ele de função expressiva. Assim, a postura do emissor é evidenciada durante a comunicação, numa “expressão direta da atitude de quem fala em relação 
àquilo de que está falando" (Id., p. 123 e 124). Essa expressão pode ser percebida também no contexto imagético. No caso da publicidade, o destaque da marca do anunciante no leiaute é uma das formas de identificar a função emotiva, além do uso de cores específicas, como as cores da própria marca, por exemplo.

A função conativa, orientada para o destinatário da mensagem, é também chamada de apelativa ao fazer-se notar por meio de um pedido ou ordem ao receptor, mesmo que isso não seja apresentado de maneira explícita (CHALHUB, 2006, p. 22). O termo conatio, em latim, significa esforço ou tentativa, e conatum é traduzido como o empenho na tentativa de influenciar outrem (JOLY, 2012; CHALHUB, 2006). Essa função da linguagem é marcada pelo uso de imperativo e vocativo, além da segunda pessoa do verbo. É interessante notar que "as sentenças imperativas diferem fundamentalmente das sentenças declarativas: estas podem e aquelas não podem ser submetidas à prova de verdade" (JAKOBSON, 2003, p. 125). Outras marcas da função conativa da linguagem são apresentadas por Sandmann (2014, p. 24 e 24) ao destacar a presença de períodos interrogativos e palavras dêiticas (pronomes demonstrativos e advérbios de lugar como aqui, lá, hoje, agora etc.). A imagem, por sua vez, também pode evidenciar a função conativa. O modelo que olha diretamente para a câmera é um exemplo, assim como sua postura corporal. Ele pode estar apontando para o receptor da mensagem, tentando interagir com ele de alguma forma ou, ainda, apresentando o produto anunciado.

Discursos e orações são, normalmente, dominados pela função apelativa da linguagem. E a publicidade é, em sua essência, conativa, já que está centrada no destinatário e tenta persuadi-lo (JOLY, 2012, p. 114). "A publicidade apropria-se, para formulação de sua linguagem, e é próprio dela, dos níveis gráfico, visual e sonoro dos signos. A organização, portanto, da mensagem da propaganda, seja qual for o veículo que a estruture [...] imporá um perfil conativo a essa linguagem" (CHALHUB, 2006, p. 25), seja ela textual, imagética ou sonora. Sandmann $(2014$, p. 27) resume bem o papel da função conativa da linguagem na publicidade (chamada por ele de propaganda), e chama atenção para o fato de que ela pode ser atestada mesmo quando não faz uso de suas marcas linguísticas típicas:

Parece-nos não ser difícil imaginar que na linguagem da propaganda a função apelativa esteja muito presente. Afinal, a constante dessa linguagem é vender um bem de consumo - um produto, um serviço - ou uma ideia; é persuadir alguém, é levar alguém a um comportamento. Naturalmente, vender um produto ou uma ideia é função de toda linguagem da propaganda e não só quando a função apelativa se faz presente com suas marcas linguísticas típicas: períodos interrogativos, verbo no modo imperativo, pronomes pessoais e possessivos de segunda pessoa, verbo na segunda pessoa, vocativos, pronomes de tratamento e dêiticos. De certo modo se pode dizer, pois, que a função persuasiva ou apelativa pode estar presente mesmo sem as marcas tradicionais que acabamos de citar. 
Diferentemente da função conativa, predominante, a função fática não é facilmente identificável na linguagem publicitária, uma vez que seu papel é evidenciar o canal da mensagem e, consequentemente, o ponto de contato entre emissor e receptor (Id., p. 26). A informação em si não é privilegiada. O objetivo da função fática é, portanto, testar o canal de comunicação e estender o tempo de interação, tendo a tautologia como traço característico (CHALHUB, 2006, p. 28). Jakobson (2003, p. 126) descreve a função fática como aquela em que a atenção do interlocutor é verificada ao longo da comunicação por meio de fórmulas ritualizadas e de frases como “Alô, está me ouvindo?” ou “Hm-hm!”. Há “diálogos inteiros cujo único propósito é prolongar a comunicação". Imagens repetidas, caracterizando redundância, e elementos gráficos que destacam o conteúdo da mensagem também caracterizam a função fática da linguagem.

A função poética enfatiza a mensagem e sua forma, e não apenas ou necessariamente seu conteúdo, como faz a função referencial. A publicidade apresenta a função poética na medida em que se preocupa com a forma da mensagem, a organização de seus elementos e sua estética (SANDMANN, 2014, p. 126). Sandmann cita Leech (Apud id., p. 29) ao destacar a presença da função poética na publicidade: "é desejável que a audiência ao menos guarde o nome do produto anunciado, e possivelmente também alguma frase-chamariz que o acompanha”. Assim, não se pode reduzir a função poética à poesia, ou ainda determinar que em toda poesia predomina a função poética da linguagem. Para Jakobson (2005, p. 127 e 128), isso "seria uma simplificação excessiva e enganadora".

Tem-se, por fim, a função metalinguística, que é centrada no código da mensagem e se utiliza desse mesmo código para comunicar. A ênfase no código dá aos atores do processo comunicacional a certeza de que a mensagem é recebida e compreendida por ambos. Conforme exemplifica Jakobson (Id., p. 127): “sempre que o remetente e/ou o destinatário têm necessidade de verificar se estão usando o mesmo código, o discurso focaliza o código; desempenha uma função metalinguística (isto é, de glosa) "Não o estou compreendendo - que quer dizer?” [...] "Entende o que quero dizer?”.

A função metalinguística permeia a publicidade na medida em que o emissor constrói a mensagem baseado em códigos conhecidos pelo receptor. Em outras palavras, "quando o emissor é consciente das relações de linguagem, a função conativa opera juntamente com o comportamento metalinguístico - pois o narrador incorpora o leitor no desenho de sua mensagem" (CHALHUB, 2005, p. 14). Sandmann (2014, p. 26), por sua vez, afirma que a função metalinguística é caracterizada "quando pedimos ou damos o significado de uma palavra 
ou sequência de palavras, fato muito frequente em textos didáticos, em que se está constantemente explicando o conteúdo de termos técnicos". O autor afirma que a função não é muito vista na linguagem publicitária. No entanto, cita alguns exemplos de sua utilização. $\mathrm{O}$ primeiro deles é de um anúncio para vender bacalhau, veiculado na revista Cláudia de dezembro de 1990, cujo texto dizia: “Bacalhau rima com Natal?”. Para ele, duas funções da linguagem são identificadas:

a primeira é a que atribui a bacalhau e Natal função metalinguística, isto é, as duas palavras se referem a si mesmas, ao seu corpo fônico. A outra leitura é a que confere a bacalhau e Natal função referencial, isto é "tipo de peixe" e "festa comemorativa do nascimento de Cristo". Rimar, além disso, está, nessa segunda leitura, em sentido metafórico, isto é, "Bacalhau combina com Natal" ou "Bacalhau vai bem na ceia de Natal (Id., p. 26 e 27, grifo do autor).

Outros exemplos da função metalinguística presente em peças de comunicação apresentados por Sandmann são de um cartaz da Federação dos Estudantes de Agronomia do Brasil, onde se lê "Ensino não rima com lucro", e um anúncio da rede de supermercados Carrefour onde é estampada a frase "Iogurtes com E. E de economia" (Ibid.).

Tem-se, portanto, descritas, as seis funções da linguagem que serão utilizadas na análise do corpus de pesquisa desta investigação. Antes de prosseguir, é importante destacar que uma função da linguagem nunca é única e exclusiva de determinada mensagem. Há outras funções que se apresentam de maneira complementar e geram significados (CHALHUB, 2006, p. 23). "É claro que nenhuma mensagem, de qualquer tipo, monopoliza uma e uma apenas dessas funções" (JOLY, 2012, p. 56). Jakobson (2003, p. 123) destaca ainda a hierarquia existente entre as funções, sendo que a função da linguagem predominante determina a estruturação verbal da mensagem correspondente.

Assim, espera-se identificar como função da linguagem predominante nos anúncios do Sebrae a função conativa, a principal função da linguagem da publicidade disseminada pelos meios de comunicação de massa. Antes de discutir esse tema, no entanto, é preciso apresentar o contexto onde eles estão inseridos.

\subsection{As teorias da comunicação}

Mauro Wolf, semiólogo e sociólogo italiano considerado um dos mais importantes especialistas em comunicação, apresenta em seu livro "Teorias das comunicações de massa" diversos estudos acerca do poder de influência da mídia sobre o público receptor da 
comunicação. Wolf chama de oscilatório o andamento histórico desses estudos que deram origem às chamadas teorias da comunicação e atribui ao clima social de cada época as diferentes abordagens do tema. Ainda segundo o autor, os estudos sobre a influência da comunicação

\begin{abstract}
partem de uma atribuição de forte capacidade manipulativa, passam depois por uma fase intermediária, na qual o poder de influência é redimensionado de modo variado, e por fim repropõem nos últimos anos posições que atribuem aos meios de comunicação de massa um efeito considerável, ainda que motivado diferentemente do afirmado na teoria hipodérmica (WOLF, 2003, p. 48 e 49).
\end{abstract}

Apesar de sua inegável relevância, o trabalho de Wolf não fornece um panorama completo dos estudos teóricos sobre a influência da comunicação. Não discute, por exemplo, a teoria do meio, elaborada por Marshall McLuhan, e também não aprofunda o debate sobre as pesquisas realizadas pela mass communication research. Estas, em particular, extremamente relevantes à presente investigação.

Com o objetivo de identificar e compreender os efeitos e as funções dos meios de comunicação de massa, as pesquisas da chamada mass communication research surgem em 1930, nos Estados Unidos da América, por ocasião da Primeira Guerra Mundial (FRANÇA, 2001, p. 53). Tendo como foco a propaganda política, uma vez que que as pesquisas da época eram financiadas pelo governo, os estudos da communication research privilegiam a análise do processo comunicacional sob o ponto de vista da relação estímulo-resposta. Em outras palavras, examinam o poder de persuasão da mensagem veiculada. Os resultados mostram, pela primeira vez na pesquisa em mídia, "a complexidade dos elementos que entram em jogo na relação entre emissor, mensagem e destinatário" (WOLF, 2003, p. 18), o que dificulta sobremaneira a apreensão completa do fenômeno comunicacional.

Surge, nesse momento, a preocupação com o contexto de produção e recepção das mensagens, o qual influencia a comunicação e por ela é influenciado. Para Wolf (Id., p. 37),

\footnotetext{
a eficácia dos meios de comunicação de massa pode ser analisada apenas dentro do contexto social em que estes agem. Sua influência deriva mais das características do sistema social a eles circunstante do que do conteúdo que difundem.
}

Assim, um dos aspectos mais intrigantes do processo comunicacional reside no receptor das mensagens, que não é passivo frente à comunicação. Pelo contrário, avalia o conteúdo recebido e define um posicionamento em relação a ele. Como afirma o autor (Ibid., p. 24), "a interpretação transforma e modela o significado da mensagem recebida, preparando-a para as 
opiniões e para os valores do destinatário, às vezes a ponto de mudar radicalmente o sentido da própria mensagem".

Porém, mesmo diante da complexidade do fenômeno comunicacional, no qual os receptores interpretam as mensagens recebidas e podem modificar seu sentido original, há situações em que ocorre, sim, a persuasão pelos meios de comunicação de massa. Portanto, para que a comunicação seja efetiva, receptor e emissor devem interpretar a mensagem da mesma maneira. Nesse sentido, o pressuposto para a efetividade da comunicação é a concretização "dos efeitos desejados ou planejados pelo emissor" (Ibid., p. 20).

Muitos estudos foram - e ainda são - realizados, de um lado, para tentar descobrir os motivos do fracasso de campanhas persuasivas e, de outro, para melhorar a capacidade de persuasão das mesmas. "De fato, há oscilação entre a ideia de que é possível obter efeitos relevantes, contanto que as mensagens sejam estruturadas adequadamente, e a evidência de que, com frequência, os efeitos pesquisados não foram atingidos" (Ibid., p. 18, grifo do autor). Fato é que uma mensagem que provoca efeitos persuasivos é criada com base nas características psicológicas do público-alvo e no contexto em que a comunicação é consumida.

Diante das descobertas proporcionadas por seus trabalhos, a mass communication research influenciou, de forma definitiva, a pesquisa em comunicação. "As aquisições mais significativas dessa teoria dos meios de comunicação de massa transformaram-se em "clássicos" e perpetuam sua presença em toda resenha crítica da literatura da mídia" (Ibid., p. 32). Dentre esses clássicos citados por Wolf estão os estudos empíricos, também chamados de teoria da mídia. Esses estudos romperam com as ideias de manipulação defendidas pela teoria hipodérmica e foram além dos estudos da persuasão realizados pela communication research ao inserirem o conceito de influência no já complexo cenário de análise. Mais uma vez, influenciar e persuadir por meio da comunicação de massa é possível, desde que sejam considerados o contexto onde a mensagem é percebida e as características psicológicas do público a que ela se destina.

Assim, os estudos empíricos conquistaram relevância acadêmica e autonomia, criando uma identidade própria (Ibid., p. 17). Em outras palavras, a história da pesquisa em comunicação apresenta uma evolução no decorrer da qual o foco dos estudos passa da manipulação para a persuasão e, posteriormente, para a influência. E não se trata unicamente da influência dos meios de comunicação de massa, mas também daquela presente nas relações sociais (Ibid., p. 32 e 33).

Em resumo, são três as esferas de interesse que se apresentam à teoria da mídia: o público-alvo e suas diferenças em relação ao modo de consumir a comunicação; o contexto 
social em que esse consumo ocorre; e a forma de construção e organização das mensagens para influenciar o público (figura 4). Wolf cita Klapper (Apud ibid., p. 43, grifo do autor) ao afirmar que

a eficácia da comunicação de massa é largamente vinculada a e dependente de processos de comunicação internos à estrutura social em que vive o indivíduo e que não são efetuados pela mídia. Nesse quadro, a capacidade de influência da comunicação de massa limita-se sobretudo ao reforço de valores, comportamentos, opiniões, mais do que a uma capacidade real de modificá-los ou manipulá-los.

Figura 4 - Esferas de interesse da teoria da mídia

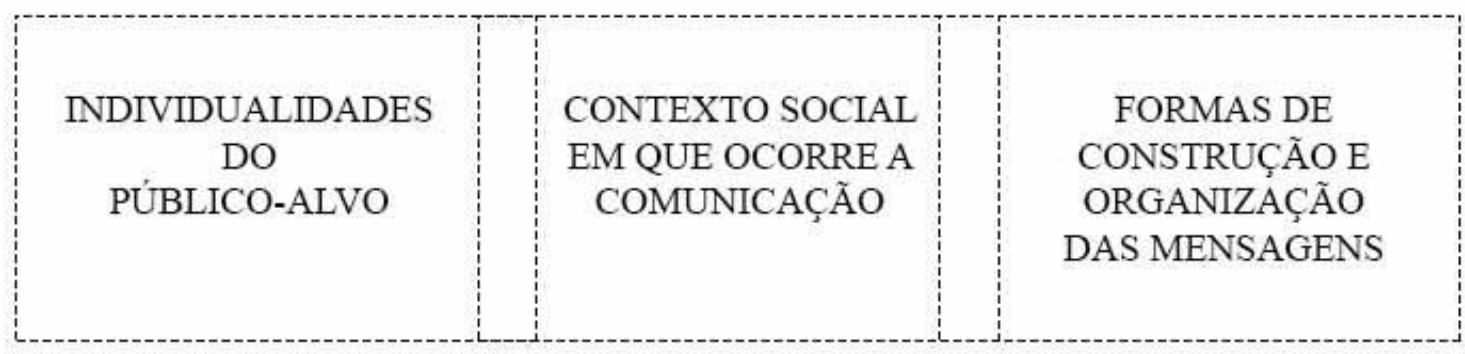

Fonte: elaborado pela autora a partir de WOLF, Mauro. Teoria das comunicações

de massa. São Paulo: Martins Fontes, 2003, p. 32 e 33.

A investigação aqui proposta busca compreender, com base nessas três esferas, como ocorre a identificação do microempreendedor individual frente à comunicação do Sebrae. As individualidades do público residem principalmente nas diferentes categorias de negócio reunidas pela legislação sob o rótulo de MEI. Já o contexto onde a comunicação acontece está ligado aos veículos de comunicação e outras estratégias de disseminação da mensagem publicitária adotadas pelo Sebrae e por suas agências de publicidade. Por fim, espera-se conhecer como a construção e organização da mensagem do Sebrae para o microempreendedor individual influencia e é influenciada pelas relações sociais.

Diante do exposto acerca das teorias da comunicação, é possível afirmar que a mass communication research e a teoria da mídia revelam-se adequadas para a fundamentação teórica deste trabalho, uma vez que o tema da pesquisa compreende três elementos igualmente importantes que interagem na dinâmica social construída pela comunicação publicitária, a saber: o Sebrae, a mensagem publicitária em si e o microempreendedor individual.

\subsection{Os meios de comunicação de massa}

Os meios de comunicação de massa são entendidos como meios técnicos e tecnológicos que permitem a disseminação de bens simbólicos, de modo simultâneo e regular, para um grupo 
amplo de indivíduos (BERGSTRÖM, 2009; CHALHUB, 2006; THOMPSON, 1995). Em outras palavras, os meios de comunicação de massa permitem grande amplitude ao processo comunicacional e seus efeitos. Como afirmou Martino (2001a, p. 33),

\footnotetext{
o processo comunicativo deixa de ser analisado em sua generalidade, não sendo mais tratado como o fundamento da consciência humana (quer em sua forma coletiva ou individual); ele passa a ser investigado como estratégia racional de inserção do indivíduo na coletividade.
}

O surgimento e o desenvolvimento dos meios de comunicação de massa conferiram um novo sentido à organização social, pois eles possibilitaram transformações radicais por meio da produção e circulação de informações, valores e conhecimentos numa escala inédita e global (PAVARINO, 2003, p. 104). Ao mesmo tempo, porém, que aproximam, os meios de comunicação de massa revelam um mundo, em certa medida, inalcançável: ele está lá, mas não pode ser experimentado, vivido diretamente (FLUSSER, 2013, p. 112 e 113). Grande parte da experiência social torna-se, assim, a experiência vivida por meio dos meios de comunicação de massa, cujos conteúdos são criados para uma multiplicidade de receptores. A partir desse pressuposto surgem as representações sociais, conceito a ser abordado adiante.

O contexto social, por sua vez, funciona como cenário para o fenômeno da comunicação não apenas em caráter limitador, mas também como impulsionador de novas comunicações, trocas diferenciadas e inovadoras (THOMPSON, 1995, p. 198). O próprio contexto pode virar protagonista da mensagem, na medida em que é representado e mediado por ela (Id., p. 202). O meio cultural, portanto, tem papel fundamental na relação entre o espectador e as mensagens e, consequentemente, em sua percepção (AUMONT, 2007, p. 98, 99 e 114). Em resumo, conteúdos semelhantes podem resultar em "compreensões, interpretações e, consequentemente, em representações diferentes, mostrando-nos que a influência dos meios de comunicação de massa possui graus e formas bastante variados, a depender das culturas locais" (PAVARINO, 2003, p. 25).

É importante destacar, também, as condições de produção das mensagens disseminadas pelos meios de comunicação de massa, que são afetadas pelo distanciamento espaço-temporal entre sua criação e sua recepção. Como afirma Thompson (1995, p. 194), 
é a situação típica de formas simbólicas que são transmitidas através de algum tipo de meio técnico.

Ao afirmar que o contexto influencia a mensagem recebida, o autor refere-se tanto ao contexto de produção quanto ao de recepção da mesma. Ao criar uma mensagem publicitária, a agência de publicidade idealiza os diferentes contextos em que ela será recebida pelo públicoalvo e essa previsão impacta a forma simbólica que está em processo de criação. Essa idealização do contexto de recepção da mensagem faz parte do processo de criação e acontece mesmo quando os profissionais envolvidos no trabalho têm, à sua disposição, informações como, por exemplo, os locais frequentados pelo público-alvo da comunicação, seu perfil sócio demográfico e seus hábitos de consumo de mídia, advindos de pesquisas de mercado. Como afirmou Thompson (1995, p. 201), essa prática "é rotineiramente incorporada às condições de produção".

Em relação ao receptor, vale destacar seu interesse e disposição para interpretar os códigos recebidos, uma vez que ele, muitas vezes, não é um elemento passivo dentro do processo. As formas simbólicas, definidas por Thompson como "expressões linguísticas, gestos, ações, obras de arte etc.” (Id., p. 9), são alvos constantes de intrincados processos de avaliação, valoração e divergência. O objetivo do emissor é gerar, na consciência do receptor, uma interpretação específica da mensagem que chega até ele (MARTINO, 2001, p. 18).

As instituições sociais, por sua vez, também influenciam a comunicação, já que possuem regras e recursos específicos que determinam as relações sociais dos indivíduos que a compõem e são, mutuamente, influenciadas por eles (THOMPSON, 1995, p. 196). O Sebrae é um exemplo de instituição social cuja missão, cujo posicionamento de marca, cujos regulamentos internos e também cujos colaboradores influenciam a comunicação com seu público-alvo, o empreendedor brasileiro.

Diante do exposto, e apesar da inegável revolução social trazida pelos meios de comunicação de massa, não se pode atribuir a eles plenos poderes. As culturas locais, as relações interpessoais e as características de cada indivíduo também controlam os processos dinâmicos que estruturam econômica, política e socialmente o mundo atual (PAVARINO, 2003, p. 26). Cada espectador é "parceiro ativo da imagem, emocional e cognitivamente (e também como organismo psíquico sobre o qual age a imagem por sua vez)" (AUMONT, 2007, p. 81). Portanto, conclui-se que "o indivíduo é mais autônomo do que se imaginava perante as mensagens persuasivas às quais está exposto cotidianamente" (CHABROL; RADU, 2010, p. 17). Tratar o receptor como um agente dentro do processo comunicacional não significa dizer 
que ele será sempre autônomo e combativo em relação à comunicação, mas que ele é capaz de assumir tais posturas diante das mensagens e confrontar as informações percebidas com suas crenças e seus valores pessoais (Id., p. 27).

\subsubsection{A publicidade}

Diante desse contexto, é necessário aprofundar a discussão sobre a publicidade, parte fundamental desta investigação. A publicidade é definida como um fenômeno social que trabalha linguagem, signos verbais e não verbais, com o objetivo de criar um código comum e persuasivo entre o emissor da mensagem publicitária e o seu receptor. Este último, por sua vez, é levado à ação desejada, normalmente caracterizada pela compra de um produto ou serviço (YANAZE, 2005, p. 54 e 88). Sandmann (2014, p. 31) chama de jogo a relação estabelecida entre emissor e receptor, onde o objetivo do primeiro é chamar atenção e provocar sensações que culminem com a memorização da mensagem e, consequentemente, levem o segundo a uma determinada ação.

É importante abordar, também, as relações entre o conceito de publicidade e o conceito de propaganda. Comumente utilizados como sinônimos, não significam a mesma coisa. Publicidade deriva do latim publicus, ou seja, tornar uma ideia ou um fato público, divulgar. Já propaganda vem de propagare, também latim, e "compreende a ideia de implantar, de incluir uma ideia, uma crença na mente alheia” (SANT'ANNA, 2005, p. 75, grifo do autor). O termo foi inicialmente utilizado para se referir à propagação de doutrinas religiosas ou princípios políticos, conforme descreve Sandmann (2014, p. 9, grifo do autor): “extraído do nome Congregatio de propaganda fide, congregação criada em 1622, em Roma, e que tinha como tarefa cuidar da propagação da fé”.

A forma como os conceitos são compreendidos e empregados varia de acordo com o idioma. Em alemão, por exemplo, o substantivo Propaganda remete à divulgação de ideias, enquanto reclame está ligado à venda de produtos e serviços. Na língua inglesa, propaganda é entendida como a disseminação de ideias, principalmente as políticas. E é o termo advertising que corresponde à divulgação de produtos e serviços. Em português essa diferenciação é menos rígida, em especial no uso cotidiano dos termos. Sandmann afirma, ainda, que "publicidade é usado para a venda de produtos ou serviços e propaganda, tanto para a propagação de ideias, como no sentido de publicidade" (Id., p. 10). Em resumo, os conceitos são comumente diferenciados baseando-se na venda de produtos e serviços, para a publicidade, e na venda de 
ideias, para a propaganda, sendo este último mais versátil na língua portuguesa, já que pode ser utilizado em ambos os casos.

Dessa forma, a presente pesquisa utiliza a palavra publicidade para referir-se à comunicação promovida pelo Sebrae, mesmo que em muitos casos as campanhas analisadas não promovam diretamente a venda de um produto ou serviço específico, e sim a ideia de formalização para o empreendedor. Seria conflituoso utilizar o termo propaganda para descrever e analisar as ações de comunicação do Sebrae, posto que a própria entidade denomina as atividades abordadas na pesquisa como publicidade. Ao incentivar que empreendedores deixem a informalidade, a publicidade do Sebrae pode ser considerada de interesse público.

Costa (2006, p. 9) define comunicação de interesse público de maneira assertiva ao afirmar que a

\begin{abstract}
comunicação é uma forma de ação. No campo institucional, ou seja, no campo dos atores que detêm grande parcela de poder nas nossas sociedades, isso significa que governos e demais agentes públicos, empresas privadas e organizações nãogovernamentais praticam ações concretas ao se comunicarem com os consumidores/clientes/cidadãos. Quando essas ações de comunicação têm como beneficiário direto a sociedade ou uma determinada parcela dela, estamos falando de Comunicação de Interesse Público. No fundo, a Comunicação de Interesse Público é um convite para que a cidadania se manifeste e se engaje nas questões cada vez mais complexas da nossa sociedade.
\end{abstract}

Para persuadir, a mensagem publicitária deve apresentar a informação de maneira clara e assertiva, a fim de evitar ruídos e ser compreendida rapidamente pelo receptor (JOLY, 2012, p. 71). Chalhub (2005, p. 16, grifo da autora) destaca que as "mensagens que introduzem ruídos, isto é, distúrbios que se inserem no canal no momento da transmissão dos sinais, alterando-a ou perturbando-a, impedem que a informação chegue de forma clara ao destinatário”.

Sandmann (2014, p. 80, grifo do autor) discorre de maneira detalhada sobre a estrutura básica do texto publicitário, composta fundamentalmente de três elementos: título, texto e assinatura.

No título, em regra uma frase, nem sempre completa, interpela-se o destinatário, põese diante dele um fato ou situação, usando naturalmente de brevidade. O texto entra em maiores detalhes a respeito do assunto ou tema apresentado no título, faz considerações diversas e mais generalizadas. Na assinatura apresenta-se, em geral, o nome do produto ou serviço, a marca, como a solução para o que se considerou nas partes anteriores.

A estrutura descrita por Sandmann não está presente em todas as peças publicitárias. Porém, é comum encontrá-la em grande parte das ações de comunicação, em especial aquelas 
que se utilizam de material impresso, como anúncios em jornais e revistas. O próprio autor pondera sobre isso ao afirmar que, assim como a estrutura do texto publicitário varia, a presença de tais elementos também não transforma, por si só, uma peça publicitária em mais criativa ou expressiva, muito menos em mais eficiente para influenciar ou persuadir. Na verdade, muitos textos publicitários convencem simplesmente pelo argumento de venda apresentado ao utilizar expressões como "tudo sem entrada" ou "leve agora e só pague depois" (Ibid., p. 94). Além disso, a estrutura clássica do texto é normalmente combinada com cores, fontes e imagens para persuadir.

Adilson Citelli é outro autor que discute técnicas e elementos de persuasão utilizados pela publicidade, tendo como referência o clássico "Técnicas de persuasão", do psiquiatra inglês J. A. C. Brown. O primeiro elemento apontado por Citelli é o uso de estereótipos que, segundo o autor, "impede qualquer questionamento acerca do que está sendo enunciado, visto ser algo de domínio público, uma "verdade" consagrada" (CITELLI, 1997, p. 46 e 47). É preciso analisar com cautela essa afirmação, uma vez que declarar que o uso de estereótipos impede qualquer questionamento sobre a mensagem é, de fato, pretensioso. Por outro lado, é compreensível que sua utilização auxilie na diminuição do risco de ruídos na comunicação, diante das características descritas por Citelli.

Outra estratégia persuasiva apontada pelo autor é o que ele chama de "apelo à autoridade", ou seja, "o chamamento a alguém que valide o que está sendo afirmado" (Id., p. 47). Exemplos podem ser facilmente identificados em mensagens publicitárias que exibem celebridades, atletas e médicos falando sobre os produtos e serviços anunciados. Os recursos de afirmação e repetição são também mencionados por Citelli como

importantes esquemas usados pelo discurso persuasivo. No primeiro caso, a certeza, o imperativo: a dúvida e a vacilação são inimigas da persuasão. No segundo caso, repetir significa a possibilidade de aceitação pela constância reiterativa (Ibid., p. 48).

Ao concluir, Citelli afirma que o discurso persuasivo é sempre o resultado de um discurso institucional, de convencimento, seja ele proveniente de grandes instituições sociais, como a igreja, a escola, o judiciário, ou vindo do que ele denomina microinstituições, como a família e outras relações sociais (Ibid, p. 32).

É relevante destacar, ainda, que uma informação fornecida nem sempre caracteriza comunicação eficaz, uma vez que a compreensão da mensagem pode se dar de maneira inesperada e indesejada pelo emissor (TAYLOR, 2010, p. 713). É ingênuo inferir que a comunicação será sempre compreendida pelo receptor exatamente como planejado pelo 
emissor (PENN, 2011, p. 325). Nesse sentido, Bergström (2009, p. 60) é categórico ao afirmar que o desenvolvimento da mensagem publicitária é crucial e pode arruinar todo o trabalho estratégico se a mesma não for transmitida corretamente. Portanto, quanto menos ruído existir no processo comunicacional, melhor.

É importante destacar ainda que falar em comunicação bem sucedida em publicidade significa dizer que a ação estimulada pelo emissor foi executada pelo destinatário da mensagem. Uma das principais maneiras de se reduzir o risco de ruídos na comunicação ocorre a partir do conhecimento sobre o público-alvo, bem como sobre o contexto social em que ele se insere. Essas informações auxiliam o emissor a prever como o destinatário da mensagem publicitária interpretará os argumentos de persuasão apresentados e que ações e comportamentos poderá adotar a partir disso (MARCOVITCH, 2005, p. 74).

Definir um público-alvo específico para a comunicação, ou seja, segmentá-lo, orienta o trabalho criativo da agência publicitária. Normalmente, essa definição surge de informações fornecidas pelo cliente da agência e obtidas por meio de pesquisas de mercado. Dados como sexo, idade, escolaridade, renda e interesses pessoais são variáveis demográficas bastante utilizadas para direcionar os trabalhos (BERGSTRÖM, 2009, p. 49). No entanto, são informações relativamente genéricas. As variáveis psicográficas, como preferência política, consciência ambiental, aversão ao risco, entre outras, são mais difíceis de serem levantadas, porém permitem construir um perfil mais claro e aprofundado do público-alvo.

Outros aspectos a serem considerados sobre o público são o contexto social em que ele está inserido e sua participação ativa no processo comunicacional, condições discutidas anteriormente. Ao absorver formas simbólicas disseminadas pelos meios de comunicação, o receptor a interpreta e avalia, produzindo significados e, ainda que em médio ou longo prazo, partilhando-os com o emissor. Esse processo é muitas vezes consciente, isto é, o receptor sabe que pode submeter as mensagens mediadas a processos de valorização e ressignificação, modificando o valor simbólico pretendido pelo emissor. Para Bergström (2009, p. 31), a perspectiva da recepção envolve percepção, sentimento e interpretação. Consequentemente, "as maneiras pelas quais as formas simbólicas são entendidas e pelas quais são avaliadas e valorizadas podem diferir de um indivíduo para outro" (THOMPSON, 1995, p. 201 e 202).

Penn (2011, p. 324) também aborda a liberdade interpretativa do público ao afirmar que "o ato de ler um texto e uma imagem é, pois, um processo interpretativo. O sentido é gerado na interação do leitor com o material”. Essa interpretação é influenciada pelas experiências que ele teve ao longo de sua vida, incluindo o contexto cultural em que ele se insere. Assim, a 
publicidade eficiente torna "explícitos os conhecimentos culturais necessários para que o leitor compreenda a imagem" (Id., p. 325).

É preciso chamar atenção para a importância que o receptor tem no processo comunicacional, mas também para a influência disso na produção das mensagens pelo emissor, questão que foi criticada por Bergström (2009, p. 68). Para o autor, ter o receptor como foco de toda a construção da mensagem é problemático porque acaba censurando o emissor e a mensagem se perde, fica generalizada. Como consequência, aquela comunicação que pressupõe a participação ativa do receptor da mensagem não acontece. $\mathrm{O}$ autor defende, assim, a importância da introspecção do emissor, uma reflexão que responda a perguntas como "quem somos nós?”, “o que queremos dizer?” e “como queremos dizer?”. Em outras palavras, o emissor para de pensar somente no receptor e reflete sobre a relação, ainda que mediada, entre ele e o destinatário da mensagem. A questão não é dizer simplesmente o que o receptor deseja ouvir, mas envolvê-lo de modo que ele se abra para ser influenciado (Id., p. 79).

De fato, é importante não limitar os objetivos da publicidade à simples tentativa de persuasão (PAVARINO, 2013, p. 17), já que publicidade não é apenas processo, é fenômeno social. Como afirma Pavarino (Id., p. 18),

a publicidade tratada como um fenômeno completo (fenômeno publicitário) diz respeito a nosso dia-a-dia [...] ela tem um papel maior, escapando de sua função mais óbvia, que seria a venda. Trata-se de algo que é ao mesmo tempo econômico, psicológico, social e, sobretudo [...] algo comunicacional.

Hoje, a publicidade é parte "de um conjunto de instituições ligadas à valoração econômica de formas simbólicas e a sua ampla circulação no tempo e no espaço" (THOMPSON, 1995, p. 212). Em outras palavras, as formas simbólicas comunicadas pela publicidade circulam em diversas esferas sociais e são negociadas economicamente por diversos atores dentro dessa dinâmica. Empresas públicas e privadas, agências publicitárias e veículos de mídia são apenas algumas das instituições ligadas à indústria da comunicação. Essa dinâmica de mercado está presente em diversos países, incluindo o Brasil, cuja publicidade é conhecida como uma das mais criativas do mundo (MARCONDES, 2002, p. 48).

Diante do exposto, fica evidente a necessidade de direcionar a presente investigação para além das ferramentas de persuasão utilizadas pela publicidade. É preciso pensar o fenômeno comunicacional como um todo para compreender "a natureza dos processos cognitivos que levam os indivíduos a mudar de atitude após a exposição a uma mensagem persuasiva" (CHABROL; RADU, 2010, p. 31). Em outras palavras, a perspectiva adotada pelo presente trabalho direciona a investigação para os fenômenos comunicacionais mediados por 
dispositivos técnicos (MARTINO, 2001a, p. 31), em especial aqueles utilizados pela publicidade, demonstrando que a pesquisa surge do e para o campo de estudos da comunicação social, apesar de seu caráter interdisciplinar que será abordado a seguir.

\section{AS FRONTEIRAS DA PESQUISA EM COMUNICAÇÃO}

O surgimento de uma disciplina é marcado por métodos particulares na abordagem de seus objetos de estudos e está ligado à tradição e às rotinas de trabalho entre os pesquisadores daquele campo. Em outras palavras, uma disciplina pode ser definida como um conjunto de investigações que se aproximam de maneira semelhante de objetos de estudo determinados. Em 2001, autores como França e Martino defendiam que a comunicação ainda não apresentava tais características. "Não há uma tradição estabelecida, o campo da comunicação ainda não constitui com clareza seu objeto, nem sua metodologia" (FRANÇA, 2001, p. 50 e 51). Atualmente, essa conjuntura já é questionada, uma vez que o campo da comunicação tem sido ampliado e consolidado no meio científico.

De qualquer maneira, essa questão pode ser justificada - ao menos parcialmente - pelo desenvolvimento acadêmico do meio. A criação e popularização dos meios de comunicação de massa financiaram a institucionalização da disciplina, o que, por conseguinte, provocou a reflexão teórica sobre esse campo de estudos. Era preciso entender a nova dinâmica criada pelo uso dos meios de comunicação, bem como seus efeitos no espaço e no tempo. Essa reflexão, no entanto, é tardia em comparação a outras disciplinas. O que se viu foi a proliferação de cursos profissionalizantes na área, antes mesmo do surgimento de teorias, fundamentais para complementar a formação técnica e para refletir sobre os impactos da comunicação nas esferas sociais e humanas. França (2001, p. 50) afirma, e essa questão permanece ainda hoje: “o espaço acadêmico da comunicação apresenta-se permeado por diferentes tensões: na articulação das teorias; na relação entre teoria e prática; na diferenciação, pluralidade e movimento de seus objetos".

Essa condição está refletida na dificuldade em se estabelecer perspectivas para as pesquisas da área, uma vez que o estágio de desenvolvimento desse campo de estudos não estabelece, no momento, um referencial teórico robusto e bem delimitado. Como resultado, o trabalho de interpretação é solicitado para tentar contornar a questão e preencher essa lacuna. Além da interpretação realizada pelo próprio pesquisador, França (Id., p. 59) menciona também a influência do contexto espaço-temporal no qual ocorre a investigação em todo o processo. 
Diante desse cenário, é justificada a apresentação e discussão de todos os conceitos apresentados anteriormente. Como afirma Lopes (2004, p. 26),

\begin{abstract}
a predisposição de tomar, como dados, objetos pré-construídos pela língua comum é um obstáculo epistemológico amplamente notado nas pesquisas de comunicação. Daí o efeito de obviedade que tem diante de muitas pesquisas de Comunicação. A reflexão epistemológica alerta para a ilusão de transparência do real, fixa o plano da ciência como plano conceitual (que exige o trabalho do e com os conceitos) e, principalmente, revela um objeto que não se deixa apreender facilmente, uma vez que é regido por uma complexidade que o torna opaco e exige operações intelectuais propriamente teóricas para sua explicação.
\end{abstract}

Julga-se necessário e pertinente, ainda, levantar algumas preocupações sobre a interdisciplinaridade fortemente presente nos estudos comunicacionais. "Põe-se em dúvida se há algum critério que possa ser usado para assegurar, com relativa clareza e consistência, as fronteiras entre as disciplinas sociais" (Id., p. 19). É, segundo Lopes, justamente esta interface o terreno onde a fraqueza teórica na pesquisa de comunicação pode se mostrar mais exposta. Essa vulnerabilidade, no entanto, deve ser vista pelo pesquisador como oportunidade para demonstrar suas habilidades ao utilizar teorias e conceitos de diferentes origens e assim construir um objeto de pesquisa consistente e sem perder o foco da comunicação. A novidade e a originalidade na pesquisa científica surgem a partir de situações como essa.

Além disso, o fenômeno comunicacional é tão fascinante e complexo que permite a vários campos fazerem dele seu objeto de estudo, cada qual com suas especificidades (MARTINO, 2007; BRAGA, 2011). O homem, objeto de estudo das ciências humanas, é um ser comunicativo por natureza, e esse aspecto é quase sempre abordado por outras disciplinas (MARTINO, 2001a, p. 28). O papel do comunicólogo, então, é "explicar a realidade humana a partir dos fenômenos comunicacionais" (MARTINO, 2007, p. 28) valendo-se de conhecimentos próprios e de áreas afins, ampliando fronteiras. Cabe lembrar que, sob essa perspectiva, a comunicação se dá como fenômeno social, e não apenas como ferramenta ideológica com função pré-determinada (LOPES, 2004, p. 17).

Diante do exposto, um dos grandes desafios da área de comunicação está na interface com outros campos de investigação que fornecem teorias e perspectivas importantes, mas ameaçam "absorver a atenção do pesquisador, por suas teorias e objetos mais tradicionalmente delineados” (BRAGA, 2011, p. 64 e 65). Para não cair em armadilhas da interdisciplinaridade, convém sempre perguntar: "o que há de comunicacional nessa interface?" (Id.).

Neste trabalho, a interface da comunicação acontece com a psicologia social sociológica, uma vez que se apoia nas representações sociais e nos processos identitários para 
analisar a comunicação. De raízes europeias, a psicologia social desenvolveu-se nos Estados Unidos da América, a partir da migração de pesquisadores que fugiam das dificuldades surgidas com a eclosão da Segunda Guerra Mundial. Com a mudança de cenário, o campo de estudos "tira o foco do comportamento e traz para a discussão os processos mentais subjacentes" (SANTOS, 2005, p. 15). Surgem, assim, a perspectiva psicológica (focada no indivíduo) e a sociológica (focada nas relações sociais).

O conceito de identidade, por sua vez, permite interpretações mais individualistas ou mais sociais. O mesmo ocorre com a teoria das representações sociais, cuja origem remete a Durkheim e seu conceito de representações coletivas, sob a perspectiva sociológica. Posteriormente é revisto e ampliado pela psicologia social, em sua abordagem psicossociológica. No Brasil, o estudo das representações sociais viveu seu ápice durante os anos 2000, tanto na diversidade de campos de estudos que adotaram este referencial, quanto no aumento numérico dos trabalhos desenvolvidos (ALMEIDA, 2005, p. 121).

Wilbur Schramm, pesquisador considerado por muitos o "pai dos estudos de comunicação", atribui a origem do campo a quatro pesquisadores da década de 1930: Kurt Lewin, Carl Hovland, Paul Lazarsfeld e Harold Lasswell (SCHRAMM, 1997, p. 3 e 4). Curiosamente, dois deles psicólogos. O fenômeno dos meios de comunicação de massa tem sido foco de estudo da psicologia social há muitos anos, inclusive com o desenvolvimento de importantes trabalhos, como os estudos de recepção e persuasão (PAVARINO, 2003, p. 9).

\footnotetext{
A diferença entre os estudos realizados [...] por ambas as disciplinas é que enquanto a psicologia social foca seus trabalhos na maneira como a percepção, o pensamento, a memória e a linguagem são utilizados para processar as informações, os comunicólogos buscavam compreender e apresentar uma nova perspectiva sobre os efeitos dos meios de comunicação de massa (Id., p. 75).
}

Dessa forma, além de investigar o impacto dos meios de comunicação de massa na sociedade, os estudos em comunicação buscam compreender como eles são organizados na dinâmica social e como suas mensagens são construídas.

\section{A REPRESENTAÇÃO E A BUSCA PELA IDENTIFICAÇÃO}

Serão discutidos nos próximos capítulos a teoria das representações sociais e os processos de identificação, cujas contribuições vêm complementar a ampla abordagem do fenômeno comunicacional proposto neste trabalho. 


\subsection{As representações sociais}

Diferentes estudiosos de inúmeras áreas do conhecimento tentam, há muito tempo, definir o termo representação. Para Nöth e Santaella (1998, p. 16), "as tentativas de delimitação do conceito são variadas, mas, frequentemente, imprecisas". A etimologia do termo traz representação como uma oposição ao conceito de apresentação, uma vez que a representação reproduz algo já existente e presente na consciência (Id., p. 19).

Sob a perspectiva semiótica, o conceito parte do inglês representation e é tratado como sinônimo de signo ou como “o processo de apresentação de algo por meio de signos" (Ibid., p. 17). Nöth e Santaella trazem, ainda, as contribuições de Peirce. Para o autor, representar é apresentar determinado objeto a um intérprete capaz de compreender o signo ou a conexão entre signo e objeto. Em outras palavras, representar é "estar para, quer dizer, algo está numa relação tal com um outro que, para certos propósitos, ele é tratado por uma mente como se fosse aquele outro" (Ibid., p. 17).

Outra contribuição trazida por Nöth e Santaella é aquela de Nelson Goodman, para quem a representação é apenas representação imagética. "Para ele, representações são imagens que têm aproximadamente o mesmo tipo de função que descrições” (Ibid., p. 19). Essas últimas, de caráter verbal. Moscovici (1978, p. 62) também reconhece a dificuldade de definição do termo e caracteriza a representação como um "processo psíquico, capaz de tornar familiar, situar e tornar presente em nosso universo interior o que se encontra a uma certa distância de nós, o que está, de certo modo, ausente".

Aumont (2007, p. 103 e 105) e Barnes (1977, p. 9) apresentam definições similares para o termo. Para eles, representação, de maneira geral, é um fenômeno que institui um substituto, seja ele uma imagem, palavra, símbolo ou outro código qualquer, e apresenta a seu espectador uma realidade ausente, dentro de um contexto específico. A utilização de um substituto é arbitrária, baseada em recursos culturais pré-existentes e convenções sociais a serem assimiladas e compreendidas por esse espectador. Sá (2002, p. 54), por sua vez, utiliza, em seu trabalho sobre o núcleo das representações sociais, a definição proposta por Abric, na qual representação é "o produto e o processo de uma atividade mental pela qual um indivíduo ou um grupo reconstitui o real com que se confronta e lhe atribui uma significação específica”.

Independentemente da definição, é possível afirmar, conforme defende Moscovici (1978, p. 58), que representar não é um processo puramente reprodutivo, no sentido de repetir, replicar. Representar é reinterpretar, reinventar, reconstituir. É um processo de construção. A partir dessa perspectiva, Moscovici se posiciona contra o individualismo então predominante 
no campo de estudos da psicologia social e defende a importância do contexto histórico e cultural para as pesquisas da área, bem como a relevância do sujeito diante desse cenário. "Para ele, o sujeito não é um simples processador de informações externas ou produto de uma realidade exterior a ele. O sujeito é ativo no processo de apropriação da realidade objetiva" (SANTOS, 2005, p. 17).

A partir dessas considerações, é possível avançar e discutir o fenômeno das representações sociais, um dos eixos desta investigação. Em seu trabalho "La psychanalyse, son image et son public", de 1961, Moscovici buscou compreender como a população parisiense assimilava, àquela época, o conceito de psicanálise (SÁ, 1993, p. 19). Surge, nessa obra, um primeiro esboço do que viria a ser a teoria das representações sociais.

O conceito desenvolvido por Moscovici baseia-se nas representações coletivas de Durkheim. Para a sociologia durkheimiana, essas representações revelam a singularidade da realidade social e são, por si sós, também "fatos sociais, coisas, reais por elas mesmas" (Id., p. 216). Em outras palavras, Durkheim define as representações coletivas como "o produto de uma imensa cooperação [...]; para fazê-las, uma multidão de espíritos diversos associaram, misturaram, combinaram suas ideias e sentimentos; longas séries de gerações acumularam aqui sua experiência e saber" (Apud ibid.). Ao fugir do individualismo predominante na psicologia social americana, ou seja, a psicologia social psicológica, os estudos de Durkheim proporcionaram a Moscovici solo fértil para o início de suas próprias investigações sobre as representações.

No entanto, enquanto Durkheim e a sociologia viam as representações como artifícios explanatórios estáticos, a psicologia social sociológica e, consequentemente, Moscovici, passaram a tratá-las como estruturas dinâmicas, em constante transformação, por meio das relações sociais (MOSCOVICI, 2012, p. 47). Além disso, um outro contexto histórico permitiu ao pesquisador delimitar seus estudos ao que chamou de sociedades modernas:

\footnotetext{
as representações em que estou interessado não são as de sociedades primitivas, nem as reminiscências, no subsolo de nossa cultura, de épocas remotas. São aquelas da nossa sociedade presente, do nosso solo político, científico e humano, que nem sempre tiveram tempo suficiente para permitir a sedimentação que as tornasse tradições imutáveis (MOSCOVICI apud SÁ, 1993, p. 22).
}

É para enfatizar a característica dinâmica e socialmente engendrada das representações que Moscovici substitui o termo "coletivo", utilizado por Durkheim, pelo "social”. Moscovici ainda vai além ao não mais considerá-las como conceito, e sim fenômeno social da atualidade. Em outras palavras, as representações sociais "são fenômenos específicos que estão 
relacionados com um modo particular de compreender e de se comunicar. Um modo que cria tanto a realidade como o senso comum" (MOSCOVICI, 2012, p. 49) sendo, assim, um caminho para a assimilação do mundo social, sua estruturação e dinâmicas (MOSCOVICI, 1978, p. 44).

É importante destacar que a psicologia social utiliza a expressão "representações sociais" indistintamente, seja ela referida à teoria ou ao objeto estudado em determinado momento. Além disso, o caráter compartilhado do conhecimento leigo e do senso comum é fundamental para caracterizar uma representação social (SANTOS, 2005, p. 21).

Quanto à sua definição, não há consenso. Doise (Apud SÁ, 2002, p. 34 e 35), por exemplo, defende a pluralidade do termo por uma característica intrínseca às próprias representações sociais, dinâmicas por natureza. Ele afirma que "uma tal concepção consensual não está absolutamente presente em Moscovici, que não considera o consenso como uma característica essencial do funcionamento ou do produto das representações sociais". Para ele, a teoria proposta por Moscovici pode ser caracterizada como uma teoria psicossociológica guarda-chuva, a partir da qual outras teorias e conceitos são desenvolvidos, incluindo teoria do núcleo central, à qual dedicou parte de seus estudos (SÁ, 2002, p. 51). Em suas palavras, a teoria das representações sociais é "basicamente uma teoria geral sobre um sistema de regulações sociais que interferem no sistema de funcionamento cognitivo" (DOISE, 1993, p. 157, tradução da autora).

Denise Jodelet, por sua vez, em uma tentativa de sistematizar esse campo de estudos, chega à seguinte definição para representações sociais:

modalidades de pensamento prático orientadas para a comunicação, a compreensão e o domínio do ambiente social, material e ideal [...] uma forma de conhecimento, socialmente elaborada e partilhada, que tem um objetivo prático e concorre para a construção de uma realidade comum a um conjunto social (Apud SÁ, 1993, p. 32).

No âmbito deste trabalho, considera-se a definição tal como apresentada por Moscovici, onde representações sociais são:

um sistema de valores, ideias e práticas, com uma dupla função: primeiro, estabelecer uma ordem que possibilitará às pessoas orientar-se em seu mundo material e social e controlá-lo; e, em segundo lugar, possibilitar que a comunicação seja possível entre os membros de uma comunidade, fornecendo-lhes um código para nomear e classificar, sem ambiguidade, os vários aspectos de seu mundo e da sua história individual e social (MOSCOVICI, 2012, p. 21).

A teoria das representações sociais pressupõe a interação entre, pelo menos, dois indivíduos, que compartilham um determinado conceito e se guiam socialmente por ele 
(MOSCOVICI, 2012, p. 40). Assim, elas têm por finalidade tornar familiar o que não é familiar, ou seja, nivelar ideias e torná-las consenso durante processos comunicacionais.

Durante qualquer processo cognitivo, criam-se signos que representam as experiências do indivíduo com o mundo real. O signo funciona como elo entre a realidade e a consciência, tanto do emissor, quanto do receptor (SANTAELLA, 1995, p. 51). O papel das representações sociais é, assim, o de ordenar esses signos para que os fenômenos se tornem familiares a todos os participantes do processo, criando significados e estabelecendo referenciais. Os objetos estranhos ao contexto são introduzidos, por meio das representações sociais, ao espaço comum onde circulam as ideias conhecidas, transformando o mundo naquilo "que pensamos que ele é ou deve ser" (MOSCOVICI, 1978, p. 61). Em outras palavras, as representações sociais "convencionalizam os objetos, pessoas ou acontecimentos que encontram" (MOSCOVICI, 2012, p. 34), dão a eles destaque e sentido, envolvem-nos em um ambiente inteligível e interpretável; naturalizam-nos.

Assim, as representações sociais configuram-se em instrumento social poderoso, pois interferem diretamente no comportamento social e simbólico, orientando as ações e relações sociais (MOSCOVICI, 1978; ABRIC, 2000). Em outras palavras, "evitar o conflito social ou individual, eis o motivo; manter a uniformidade e a integridade, eis o resultado que se espera" (MOSCOVICI, 1978, p. 271).

Abric lista, de maneira sistemática, quatro funções das representações sociais. A primeira delas é a função de saber, que permite a compreensão, interpretação e consequente comunicação da realidade social na qual o indivíduo está inserido. A segunda, chamada pelo autor de função identitária, "possibilita uma identidade grupal e, por consequência, permite a diferenciação grupal” (SANTOS, 2005, p. 34), tornando visível a especificidade dos grupos (SÁ, 2002, p. 43 e 44). Há também a função de orientação, já que as representações sociais atuam comumente como guias de comportamentos sociais, ditando como devem se dar as relações sociais, o que é aceitável e o que não é. Em outras palavras, essa função "define o que é lícito, tolerável ou inaceitável em um dado contexto social” (Id.). Por fim, outra função das representações sociais é chamada de justificatória ou justificadora, e permite ao indivíduo explicar comportamentos e tomadas de decisão àqueles que partilham do mesmo convívio social. Segundo Abric (2000, p. 30), “elas intervêm também na avaliação da ação, permitindo aos atores explicar e justificar suas condutas em uma situação ou face a seus parceiros".

Para o presente trabalho, as funções mais relevantes das representações sociais são a função de saber e a identitária. Em primeiro lugar, a comunicação do Sebrae, por meio de campanhas publicitárias, apresenta ao público empreendedor uma nova pessoa jurídica 
denominada de microempreendedor individual. Em segundo lugar, busca a identificação desse público com essa nova categoria jurídica para, assim, persuadi-lo a formalizar seu negócio. De maneira complementar, as funções de orientação e justificatória se fazem presentes ao direcionarem o comportamento daquele que é microempreendedor individual, além de legitimarem a conduta desse público. Em outras palavras, o microempreendedor individual é aquele empresário que age de acordo com a legislação e deve pagar seus impostos periodicamente, em oposição ao empreendedor que trabalha na informalidade.

Nesse sentido, é possível perceber como a teoria elaborada por Moscovici é relevante para o campo de estudos da comunicação tanto por chancelar a comunicação de massa como elemento-chave na elaboração do senso comum, quanto por contribuir para os estudos cognitivos (PAVARINO, 2003, p. 11). “Através da comunicação, as pessoas e os grupos concedem uma realidade física a ideias e imagens, a sistemas de classificação e fornecimento de nomes" (MOSCOVICI, 2012, p. 90 e 376).

A comunicação, portanto, faz parte do fenômeno das representações sociais. O próprio Moscovici já defendia a importância de se "estudar as representações sociais embrenhadas nas relações de comunicação" (DOISE, 1993, p. 169, tradução da autora), uma vez que elas se influenciam mutuamente no contexto social. Santos (2005, p. 22) afirma que comunicação e representações sociais são interdependentes, e que uma não existe sem a outra. Abric (2000, p. 28 e 29) compartilha dessa visão ao declarar que as representações sociais não apenas facilitam a comunicação, mas são, provavelmente, condição necessária para sua existência. O mesmo pensamento é ainda defendido por Moscovici (1978, p. 78): “a comunicação é um instrumento que torna possível a existência das representações sociais e é, ao mesmo tempo, moldada por elas".

A publicidade, por sua vez, faz uso de representações sociais para auxiliar o processo comunicacional (LANGE, 2005, p. 23), aproximar-se, estabelecer vínculo e persuadir o público-alvo da mensagem, visto que a "atribuição de valor que é dada a um objeto pelo discurso publicitário [...] só existe a partir do ponto em que este valor é reconhecido socialmente, por determinado segmento que compartilha certos comportamentos e visões do mundo" (Id., p. 34). As representações sociais, nesse sentido, podem ser vistas como ferramentas que auxiliam o processo comunicacional e a simulação da consciência de outrem, como afirmou França (2001, p. 17).

Rouquette assume uma posição crítica ao refletir sobre como e quanto a comunicação de massa influencia as representações sociais - e vice-versa. O autor defende, inclusive, que ambos os conceitos são "ainda muito soltos do ponto de vista do rigor científico" e que 
“diferentes abordagens nesse campo frequentemente se dão de maneira intuitiva, pois não são baseadas em uma teoria bem fundamentada" (ROUQUETTE, 1996, p. 222, tradução da autora). Polêmicas à parte, qualquer trabalho científico que não vá além de atestar a existência dessa influência mútua é ingênuo. "A questão não é se um age sobre o outro, mas o que age sobre ambos" (Id., p. 226).

Para aprofundar a análise, é preciso expandir o foco e investigar os contextos de produção e de recepção da comunicação e das representações, suas dinâmicas e relações, "ao invés de procurar, de maneira apenas descritiva, correspondências entre ambas" (Ibid., p. 223). É exatamente esse o tipo de análise proposto na presente pesquisa: avaliar não apenas a estruturação da mensagem publicitária do Sebrae, mas também as conjunturas de produção e recepção dessa comunicação, incluindo o microempreendedor individual, público-alvo das campanhas.

Diante do exposto, é possível encaminhar a investigação e identificar os elementos e processos estruturantes das representações sociais para compreender seu funcionamento. Segundo Moscovici, são dois os mecanismos que as compõem: a ancoragem e a objetivação, conceitos fundamentais da chamada macro teoria de Moscovici que abrangem tanto os componentes simbólicos, quanto figurativos das representações sociais (ALMEIDA, 2005, p. 126). A partir dessas duas dinâmicas é possível explicar a realidade social, definir a identidade grupal, orientar comportamentos e práticas e justificar tomadas de posição, conforme as funções apresentadas anteriormente. Todas elas "repousam em última análise sobre a dinâmica da familiarização que rege os processos formadores das representações” (SÁ, 2002, p. 48).

A ancoragem é um processo que busca classificar e dar nome a algo não conhecido, baseando-se em categorias particulares preexistentes. Em outras palavras, ancorar é classificar um objeto desconhecido, inserindo-o em um contexto habitual para que, associado a elementos ali presentes, adquira sentido (MOSCOVICI, 1978, p. 113). Jodelet (Apud SÁ, 2002, p. 46) definiu o mecanismo da seguinte maneira: "a ancoragem consiste na integração cognitiva do objeto representado a um sistema de pensamento social pré-existente e nas transformações implicadas em tal processo”. Já Santos (2005, p. 32 e 33) chama atenção para a rede de significações criada pela ancoragem em torno do objeto desconhecido, enquanto Sá (1993, p. 37 e 38) denomina o processo de integração cognitiva e a rede de significações de sistemas de acolhimento de novas representações. Rose (2011, p. 354), por sua vez, é mais objetiva: “um objeto social novo, e não familiar, se tornará mais familiar à medida que assimilado a um outro que já o seja". 
“Coisas que não são classificadas e que não possuem nome são estranhas, não existentes e ao mesmo tempo ameaçadoras" (MOSCOVICI, 2012, p. 61). Por isso, surge a necessidade de contextualizá-las, compará-las aos paradigmas vigentes para cada uma das categorias já estabelecidas. Moscovici (Id., p. 63) exemplifica: "quando nós sintonizamos o rádio no meio de um programa, sem conhecer que programa é, nós supomos que é uma "novela" se é suficientemente parecido com $\mathrm{P}$, quando $\mathrm{P}$ corresponde ao paradigma de uma novela".

Nesse sentido, a comparação é um recurso chave da ancoragem, uma vez que o desconhecido é comparado a um protótipo aceito como representante de determinada categoria. O protótipo é um ponto de referência para a avaliação que se faz do objeto ou ideia incomum. A partir da ancoragem, o que antes era desconhecido assume, então, as características da categoria selecionada por meio de uma reclassificação. Assim, não há mais estranheza, pois o que destoava foi realocado e poderá, portanto, ser imaginado, representado e também comunicado. A ancoragem, no entanto, "não é necessariamente um processo suave" (DOISE, 1993, p. 163, tradução da autora).

Outro mecanismo que compõe o fenômeno das representações sociais é chamado objetivação e visa tornar tangível o abstrato, transformá-lo em algo concreto, palpável, que faz parte do mundo físico e pode ser visto ou tocado (MOSCOVICI, 2012, p. 61). Em seus primeiros estudos sobre as representações sociais, Moscovici (1978, p. 111) utiliza os verbos materializar e transplantar para descrever o processo, uma vez que o conceito é materializado e, assim, transplantado para o nível possível da observação. Além disso, traz a ideia da imagem como produto da objetivação (Id., p. 289).

A definição de Jodelet (Apud SÁ, 2002, p. 47) é bastante parecida. Para ela, “a objetivação consiste em uma operação imaginante e estruturante, pela qual se dá uma forma ou figura - específica ao conhecimento acerca do objeto, tornando concreto, quase tangível, o conceito abstrato, como que materializando a palavra”. Santos (2005, p. 31) também destaca o aspecto figurativo trazido pela objetivação ao afirmar que o processo "transforma um conceito em uma imagem ou em núcleo figurativo".

Em resumo, objetivar é reproduzir um conceito em uma imagem. Assim como fez com a ancoragem, Moscovici exemplifica a objetivação: "temos apenas de comparar Deus com um pai e o que era invisível, instantaneamente se torna visível em nossas mentes, como uma pessoa a quem nós podemos responder como tal” (MOSCOVICI, 2012, p. 71 e 72).

A representação social do microempreendedor individual, objeto de investigação do presente trabalho, será estudada utilizando como referência esses dois mecanismos: a ancoragem e a objetivação. A ideia desconhecida de que fala Moscovici é exemplificada pelo 
próprio MEI, uma vez que a figura jurídica surgiu em 2009 e, à época, ainda não era familiar ao público-alvo da mensagem. De maneira ideal, a ancoragem incorpora o conceito de MEI à categoria e ao paradigma de empresário e, posteriormente, objetiva esse conceito ao associá-lo a uma determinada imagem (figura 5).

Figura 5 - Ancoragem e objetivação

\title{
REPRESENTAÇÕES SOCIAIS
}

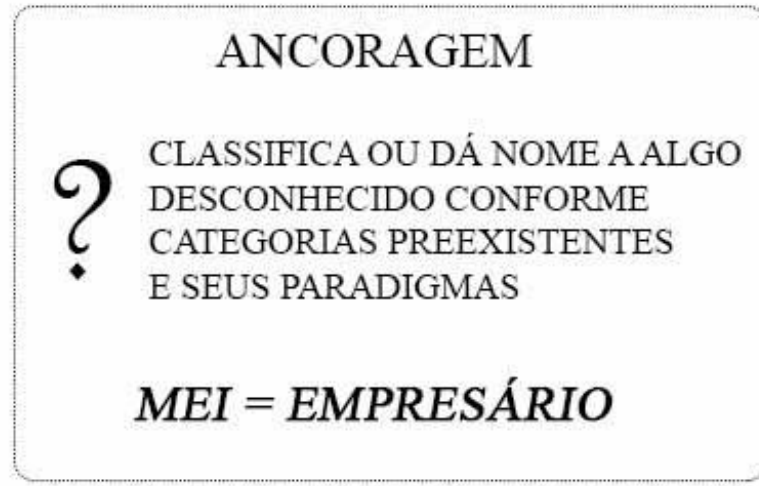

\author{
OBJETIVAÇÃO \\ REPRODUZ O CONCEITO EM \\ IMAGEM, PRODUZ A \\ MATERIALIZAÇÃO \\ - DAabstração \\ IMAGEM DO MEI/EMPRESÁRIO
}

Fonte: imagem elaborada pela autora

Por fim, é importante revelar que nem todos os conceitos poderão ser objetivados. Em outras palavras, "nem todos os objetos do ambiente social chegam a se constituir em objetos de representação de algum grupo ou conjunto social" (SÁ, 2002, p. 42), e nem todos podem ser objetivados, ou seja, associados a imagens, uma vez que a disponibilidade destas é menor. A esse fenômeno Abric e Flament denominaram não-representação (Id., p. 71 e 72). Como afirma Moscovici (MOSCOVICI, 2012, p. 72),

\footnotetext{
nem todas as palavras [...] podem ser ligadas a imagens, seja porque não existem imagens suficientes facilmente acessíveis, seja porque as imagens que são lembradas são tabus. [...] Parece, então, que a sociedade faz uma seleção daqueles aos quais ela concede poderes figurativos, de acordo com suas crenças e com o estoque preexistente de imagens.
}

Diante do exposto, é possível que esta pesquisa identifique a não-representação do conceito de empresário e, consequentemente, de microempreendedor individual. Conforme afirmou Ibañez (Apud SÁ, 2002, p. 41): "pode ser que um determinado objeto tão só dê lugar a uma série de opiniões e de imagens relativamente desconexas". Ao avaliar tanto o contexto de produção e recepção da comunicação, será possível conhecer, caso exista, a representação social do MEI. Assim, a próxima seção discute, no âmbito da recepção, como ocorrem os processos de identificação e os mecanismos que os desencadeiam. 


\subsection{Os processos de identificação}

Assim como as representações sociais impactam a publicidade, que as utiliza como matéria-prima para comunicar e persuadir, a criação e manutenção das identidades nas esferas individual e social são, também, influenciadas pelas representações sociais. As pessoas não vivem isoladamente, elas compõem e constroem diferentes identidades a partir de suas interações sociais (MAGIOGLOU, 2008, p. 450). Em outras palavras, “o sujeito, previamente vivido como tendo uma identidade unificada e estável, está se tornando fragmentado; composto não de uma única, mas de várias identidades, algumas vezes contraditórias e não resolvidas" (HALL, 2011, p. 12). Tajfel (1982, p. 290) foi um dos primeiros autores a abordarem o conceito de identidade. Ele a definiu como "aquela parcela do autoconceito dum indivíduo que deriva do seu conhecimento da sua pertença a um grupo (ou grupos) social, juntamente com o significado emocional e de valor associado àquela pertença".

Pinheiro (2004, p. 166) e Hall (2011, p. 38 e 39) chamam atenção, ainda, para o caráter dinâmico da identidade ao afirmarem que ela é construída ao longo da vida do indivíduo e é fruto de processos inconscientes e das relações sociais que esse indivíduo estabelece ao longo de sua existência. Pinheiro descreve o fenômeno como a busca por uma coerência discursiva, onde o indivíduo recolhe e processa narrativas, enquanto Hall caracteriza a identidade como algo que nunca está completo, finalizado. Afirma, ainda, que "existe sempre algo "imaginário" ou fantasiado sobre sua unidade" (Id.). Além disso, por seu caráter flexível, sugere a utilização do termo identificação no lugar de identidade.

Tajfel, por sua vez, destaca a importância do contexto social, em especial das relações dentro de e entre grupos, para a construção da identidade. Em suas palavras, a identidade social é "entendida como derivando de forma comparativa e "relacional" das pertenças dum indivíduo a grupos" (TAJFEL, 1982, p. 315). Como cada um compreende seu pertencimento a determinados grupos (e não a outros), o valor atribuído a esse pertencimento e sua carga emocional contribuem de maneira importante para a construção da identidade, influenciando, em última instância, os comportamentos do indivíduo em seu contexto social (Id., p. 294).

O conceito de grupo no âmbito desta investigação não se refere àquele que simplesmente determina um conjunto de pessoas reunidas num espaço-tempo demarcado, pois tal descrição é superficial diante da complexidade do fenômeno estudado. Assim, a presente pesquisa se apropria da definição defendida por Tajfel (Ibid., p. 289 e 290), na qual grupo configura-se numa entidade cognitiva de grande significado para o indivíduo estruturada por meio de um 
processo denominado categorização social, "através do qual se reúnem os objetos ou acontecimentos sociais em grupos, que são equivalentes no que diz respeito às ações, intenções, e sistemas de crenças do indivíduo". Outros autores como Berger e Luckmann e Schutz (Apud ibid., p. 291) também compartilham dessa definição, uma vez que consideram "a categorização social como um sistema de orientação que ajuda a criar e a definir o lugar do indivíduo na sociedade". A categorização social funciona como um instrumento que auxilia na diferenciação entre grupos dentro de uma realidade social.

Tajfel (Ibid., p. 339) vai além e apresenta, ainda, as duas principais características para se determinar um grupo social. A primeira delas é a semelhança entre os destinos ou, em outras palavras, os objetivos dos membros de um grupo. A segunda é a própria semelhança entre eles. Lembrando, novamente, que os indivíduos participantes de um sistema social assumem várias identidades e pertencem, ao mesmo tempo, a diversos grupos sociais.

Destaca-se ainda que o processo de identificação se dá tanto pela semelhança (entre membros de um mesmo grupo, por exemplo), quanto pela diferença (um indivíduo reconhece que pertence a determinado grupo porque é diferente dos membros de outro grupo). Conforme descreveu Tajfel (Ibid., p. 294), "um grupo torna-se um grupo no sentido em que existe a percepção de que tem características comuns, ou um destino comum, sobretudo porque existem outros grupos no meio". Alguns grupos sociais são diferenciados de outros mais facilmente, como por exemplo, aqueles cujas características são gênero, linguagem, idade, renda etc. Essa diferenciação fica a cargo do observador, que pode estabelecer "sua própria "construção", de qualquer "realidade" social particular" (Ibid., p. 58 e 59).

Assim, utilizando a prerrogativa do observador para esta investigação, são identificados diversos grupos que compõem a categoria social de microempreendedor individual, que corresponde aos empresários cujos negócios estão formalizados de acordo com a legislação vigente e correspondente ao MEI. Em outras palavras, a categorização social de microempreendedor individual funciona como um grande guarda-chuva onde são organizados grupos sociais correspondentes às ocupações permitidas pela lei. Assim, é possível identificar o grupo das costureiras, o grupo dos pipoqueiros, o grupo das doceiras, e assim por diante.

Nesse sentido, cabe citar a categorização social oposta àquela de microempreendedor individual, ou seja, a dos empreendedores informais que atendem aos requisitos para se tornarem microempreendedores individuais, mas que ainda não se formalizaram. Partindo da mesma lógica, essa categoria social também é composta por diversos grupos sociais.

Quais são as condições mínimas necessárias para que um indivíduo se reconheça em determinado grupo e não em outro? Compreender se e como os indivíduos percebem a si 
mesmos dentro de grupos sociais esbarra em dificuldades interpretativas e metodológicas já previstas por Tajfel (Ibid., p. 118 e 169):

\begin{abstract}
O trabalho experimental sobre a percepção de pessoas tem sido sempre limitado pelas dificuldades inerentes à natureza dos problemas estudados. Estas investigações procuram alargar o âmbito das generalizações possíveis sobre a forma como as pessoas percepcionam, avaliam ou julgam as outras pessoas. [...] No caso do meio social, não se trata só do fato de que a informação recebida (por exemplo, sobre as características pessoais de pessoas) é, em geral, muito mais ambígua para interpretar, além de lhe faltarem critérios claros para a sua validade.
\end{abstract}

Nesse sentido, o presente trabalho busca compreender a complexa questão da identidade social sob dois aspectos: um coletivo, com as contribuições de Tajfel sobre a realidade social, e outro individual, com a teoria da identidade descrita por Burke e Stets, apresentada a seguir.

A teoria da identidade também parte do pressuposto de que um mesmo indivíduo possui diferentes identidades e cada uma delas contém um conjunto de significados que a caracteriza. Burke e Stets chamaram esse conjunto de identidade padrão. Em outras palavras, a identidade padrão é um ponto de referência para o indivíduo na medida em que estabelece um modelo ou protótipo que o auxilia na definição de quem ele é (figura 6).

Figura 6 - Resumo do conceito de identidade padrão

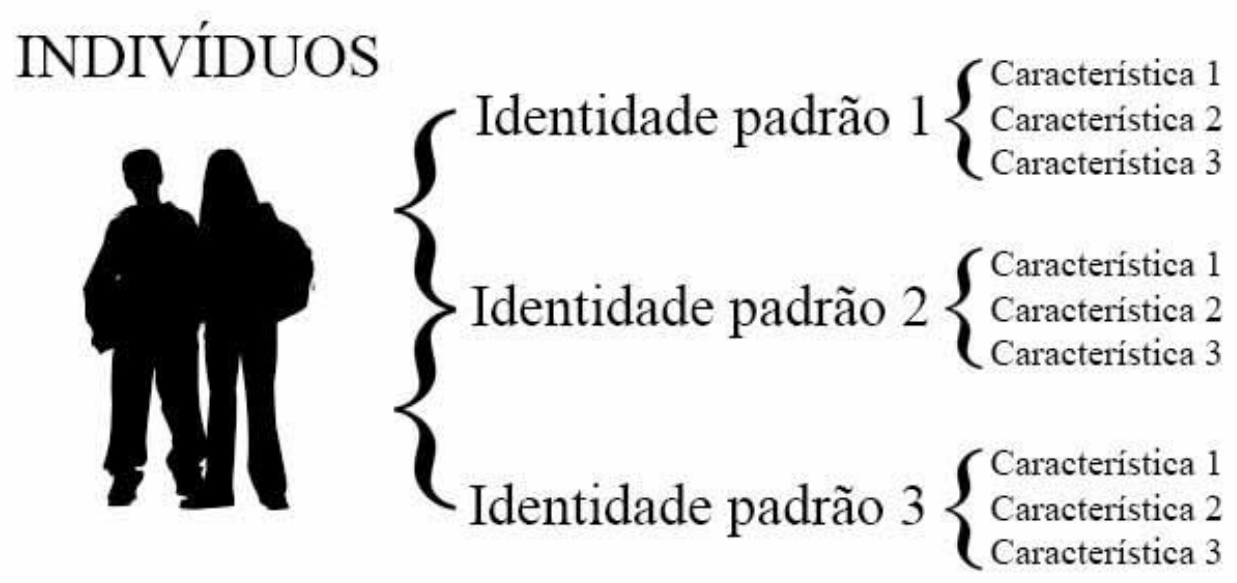

Fonte: imagem elaborada pela autora

Assim como as representações sociais, a identidade padrão é acessada por meio da memória. Em suas investigações, os autores aprofundam a discussão sobre a origem das características de cada uma das identidades padrão (BURKE; STETS, 2009, p. 64). Para este trabalho, no entanto, é preciso apenas considerar a influência das representações sociais nesse 
processo, ou seja, compreender que muitas das características que formam as identidades padrão surgem a partir de representações sociais.

Dessa forma, a identidade padrão indica ao indivíduo como determinadas situações sociais e seus significados "devem ser". Dado que a identidade padrão é uma referência individual, a expectativa de como os significados situacionais “devem ser" é diferente para cada um. Os autores traduzem essa dinâmica no que chamam de modelo de identidade (figura 7).

Os quatro elementos-chave que compõem o processo de identidade são organizados em um sistema de controle que opera para controlar a entrada de estímulos no sistema. Assim como um termômetro opera para controlar a temperatura que ele "percebe", uma identidade controla os significados que ela percebe" (Id., p. 62 e 63, tradução da autora).

Figura 7 - O modelo de identidade de Burke e Stets

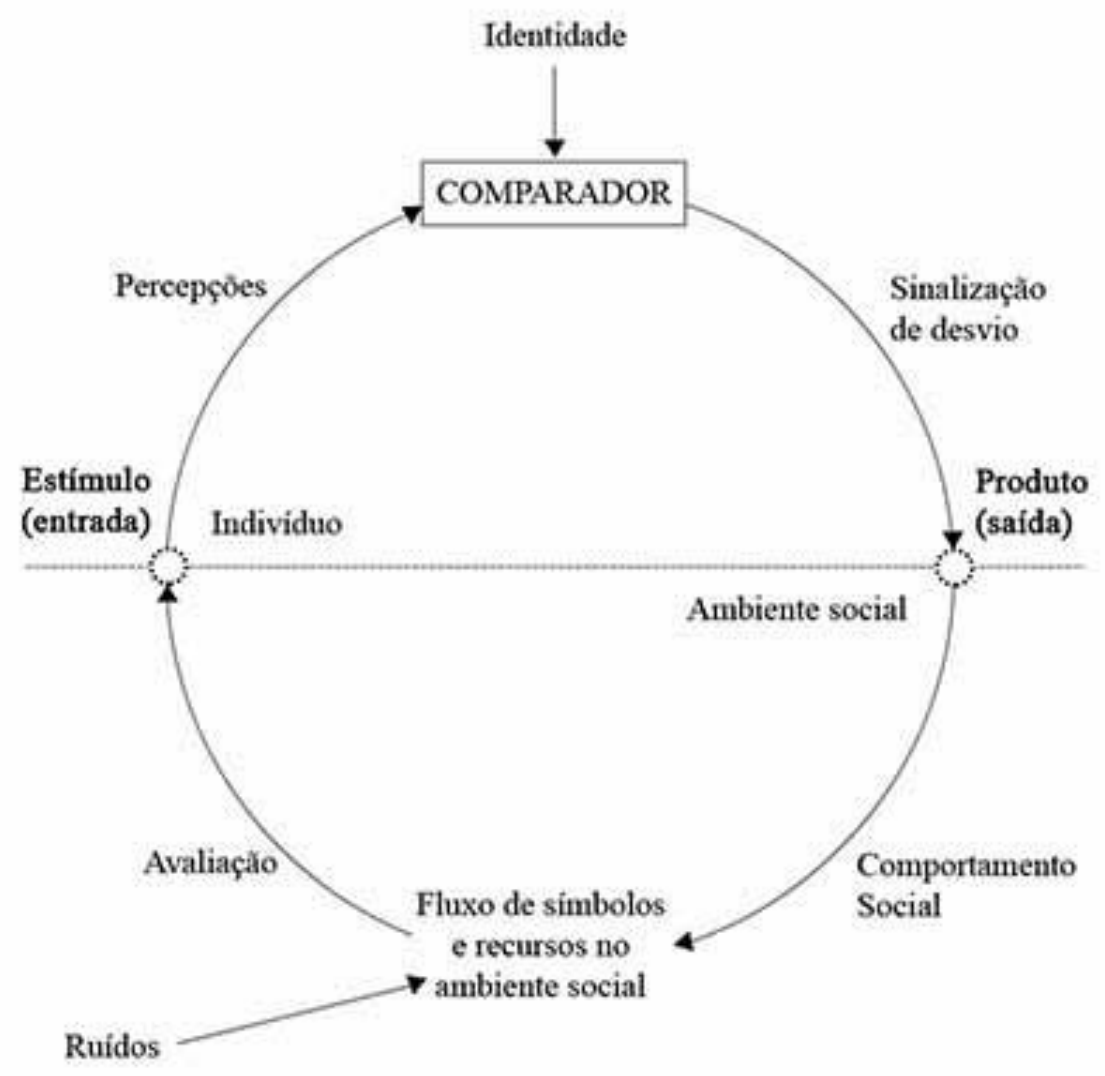

Fonte: BURKE, Peter J.; STETS, Jan E. Identity Theory. New York: Oxford University Press, 2009, p. 62

A dinâmica do modelo tem início na entrada de um estímulo, ou seja, os significados percebidos de uma situação, o fluxo de símbolos e os recursos presentes no ambiente social. Os significados percebidos externamente passam, então, por uma avaliação, que é feita pelo que os autores chamam de comparador, um mecanismo que compara os significados percebidos 
com a identidade padrão presente na memória do indivíduo. O comparador gera uma sinalização de desvio, que nada mais é do que a diferença entre o estímulo percebido e a referência, ou seja, a identidade padrão. "O processo básico de operação de identidades pode ser caracterizado como uma verificação de identidade" (Ibid., p. 68, tradução da autora).

Esse processo de verificação de identidade é chamado por Festinger de teoria da comparação social. Conforme detalhou Tajfel (1982, p. 292),

na sua teoria sobre os processos de comparação social, Festinger pôs a hipótese de que "existe no organismo humano um impulso para avaliar as suas opiniões e capacidades". A sua segunda hipótese principal, no mesmo artigo, era que "na medida em que não houver meios objetivos, não-sociais, as pessoas avaliarão as suas opiniões e capacidades comparando-as respectivamente, com as opiniões e capacidades dos outros".

Na teoria de Burke e Stets, caso a verificação promovida pelo comparador, dentro de determinada situação social, esteja de acordo com a identidade padrão, o resultado do processo é a manutenção do comportamento social, que, por sua vez, impacta o ambiente externo e reinicia o processo. Caso a percepção não se coadune com a identidade padrão, é deflagrada uma mudança no comportamento social do indivíduo, na tentativa de ajustar essa percepção com a identidade padrão estabelecida. O produto dessa dinâmica, ou seja, o comportamento, é produzido no ambiente social, da mesma forma que o estímulo se origina dele. Em resumo, o produto (saída) é alterado para que os estímulos (entrada) correspondam ao conjunto de significados da identidade padrão (BURKE; STETS, 2009, p. 63).

A bem-sucedida verificação de identidade leva a um aumento da autoestima dos indivíduos, enquanto o contrário gera frustração e estresse e, por isso, motiva a mudança de comportamento. Tajfel (1982, p. 58) afirma que "a noção de identidade social baseia-se no simples pressuposto motivacional de que os indivíduos (pelo menos na nossa cultura) preferem uma imagem de si próprios positiva, a uma negativa”. Essa característica é um dos pilares da teoria da comparação social de Festinger, segundo a qual "um indivíduo esforça-se por conseguir um conceito ou imagem satisfatória de si próprio" (Id., p. 289).

Nesse sentido, agir é uma estratégia do indivíduo para ajustar as percepções que ele tem da situação e fazer com que elas correspondam à identidade padrão estabelecida (BURKE; STETS, 2009, p. 108). Quando a verificação falha de maneira recorrente, há duas possíveis consequências: ou o indivíduo se afasta da interação que gera a dissonância, ou ele modifica sua identidade padrão. Ou seja, quando uma identidade não é verificada, "precisamos achar 
meios para reestabelecer a normalidade dos processos ou então achar novas identidades" (Id., p. 77, tradução da autora).

Tajfel (1982, p. 294) discorre sobre a questão sob o ponto de vista coletivo. Para o autor, quando o grupo não consegue proporcionar ao indivíduo condições adequadas para a manutenção de sua identidade, ele poderá abandoná-lo tanto psicologicamente, quanto objetivamente.

\footnotetext{
Podemos supor que um indivíduo tenderá manter-se como membro dum grupo e a procurar pertencer a novos grupos se esses grupos contribuíram, de alguma maneira, para os aspectos positivos da sua identidade social; ou seja, para aqueles aspectos dessa identidade que lhe dão alguma satisfação. Se um grupo não preenche este requisito, o indivíduo tenderá a abandoná-lo (Ibid., p. 291).
}

Alguns fatores podem dificultar ou mesmo impedir esse abandono, como uma impossibilidade social de deixar o grupo, o que Tajfel chama de "razões objetivas", ou se houver um conflito moral relevante envolvendo a mudança de grupo. Em outras palavras, as circunstâncias que permitem a mobilidade social envolvem considerável flexibilidade e garantia de não haver punições por parte dos grupos envolvidos, além, é claro, da busca pela autoimagem satisfatória, processo denominado por Burke e Stets de verificação de identidade padrão.

Como cada indivíduo assume várias identidades, há inúmeras identidades padrão e a dinâmica apresentada por Burke e Stets ocorre independentemente para cada uma delas. O que vai determinar qual identidade será avaliada é a relevância do estímulo percebido para a identidade em questão (BURKE; STETS, 2009, p. 65). A identidade é trabalhada pelos autores como um sistema de controle e não é, portanto, um processo linear de causa e efeito (Id., p. 72). Pelo contrário, acontece continuamente, independentemente da fonte e do conteúdo das percepções, num ciclo sem fim.

A partir da discussão apresentada sobre os processos de identificação, é possível perceber a relevância do modelo apresentado para a investigação aqui proposta, uma vez que a publicidade cumpre o papel de estímulo originado no ambiente social e gera percepções que dão início ao processo de verificação de identidade.

É interessante notar que a estratégia utilizada pela publicidade do Sebrae, cujo objetivo principal nos primeiros anos de campanhas era justamente a formalização, é mostrar ao públicoalvo os benefícios de se pertencer ao grupo dos microempreendedores individuais. Nesse sentido, a valorização da categoria social do MEI é o principal argumento para a persuasão. Existe, de forma indireta, a comparação entre o grupo daqueles empresários formalizados e o 
grupo daqueles informais, sendo que os benefícios sociais atrelados à formalização funcionam de maneira a valorizar a identidade social do microempreendedor individual e motivar a troca de grupos. Assim, o momento da formalização é o momento que marca essa troca e, consequentemente, a mudança na identidade social do empresário.

Para que esse processo ocorra, no entanto, é importante que o empreendedor perceba a si mesmo como membro de uma categoria, seja aquela dos empreendedores informais, seja o dos microempreendedores individuais. É importante que ele também perceba as vantagens de se formalizar. Muitos empreendedores ainda veem com descrença os benefícios da formalização, principalmente no que se refere ao pagamento de impostos e possíveis fiscalizações. Outro aspecto relevante é a desconfiança com a qual o governo é visto pelo público. Nesse sentido, a comunicação do Sebrae busca continuamente se desvincular do governo, visto que muitos acreditam que a entidade é um órgão governamental.

A dinâmica presente na persuasão pretendida pelo Sebrae também pode ser explicada sob o ponto de vista da teoria de Burke e Stets da seguinte maneira: ao se deparar com os anúncios (estímulos externos), um processo de verificação de identidade é iniciado no públicoalvo da mensagem. Quando o receptor trabalha de maneira informal, essa verificação não ocorre, ele possivelmente se sente frustrado e busca, de alguma forma, corrigir essas percepções para que a verificação da identidade se concretize.

O objetivo da comunicação do Sebrae é, portanto, que o comportamento de formalização seja a ação executada pelo empreendedor na busca pela verificação de sua identidade como empresário - lembrando, mais uma vez, que o termo empresário designa aquele empreendedor cujo negócio é formalizado. É importante destacar, no entanto, que o próprio termo empresário pode ser controverso entre o público, e que muitos deles não se viam como tal em pesquisa datada de 2009 e apresentada anteriormente.

Em sua publicidade, o Sebrae utiliza imagens de microempreendedores individuais, fictícias ou não, e exibe, de maneira explícita, os benefícios da formalização. Essas imagens surgem da representação social do MEI, criada pelos mecanismos de ancoragem e objetivação apresentados anteriormente. Nesse sentido, a representação social tem como uma de suas funções desencadear o processo de comparação social no público-alvo comunicação (ABRIC, 2000, p. 29). Ao discorrer sobre a imagem na comunicação, em especial na publicidade, Bergström (2009, p. 157) também reflete sobre a dinâmica da comparação ao afirmar: "nós nos refletimos nas imagens, mas também vemos outra pessoa que vive outra vida em outra realidade e com experiências completamente diferentes. [...] de repente, temos outro sexo, outra cor de pele e assumimos o melhor ou pior de nós". O cenário descrito pelo autor é, na verdade, a 
situação ideal prevista e desejada pelo anunciante. Porém, nem sempre o público se vê refletido nas imagens presentes na comunicação.

De maneira resumida, o presente trabalho defende que a representação social do MEI deve traduzir-se na imagem que o Sebrae utiliza em sua publicidade e que essa imagem, por sua vez, deve deflagrar um processo de identificação no público-alvo, com o objetivo de persuadi-lo. Tanto a identidade social dos microempreendedores individuais, quanto as imagens presentes nos anúncios do Sebrae surgem da representação social desse conceito. A figura 8, a seguir, resume essa dinâmica.

Figura 8 - Quadro resumo da dinâmica entre a representação social do MEI, sua imagem na publicidade do Sebrae e a identidade social do público-alvo

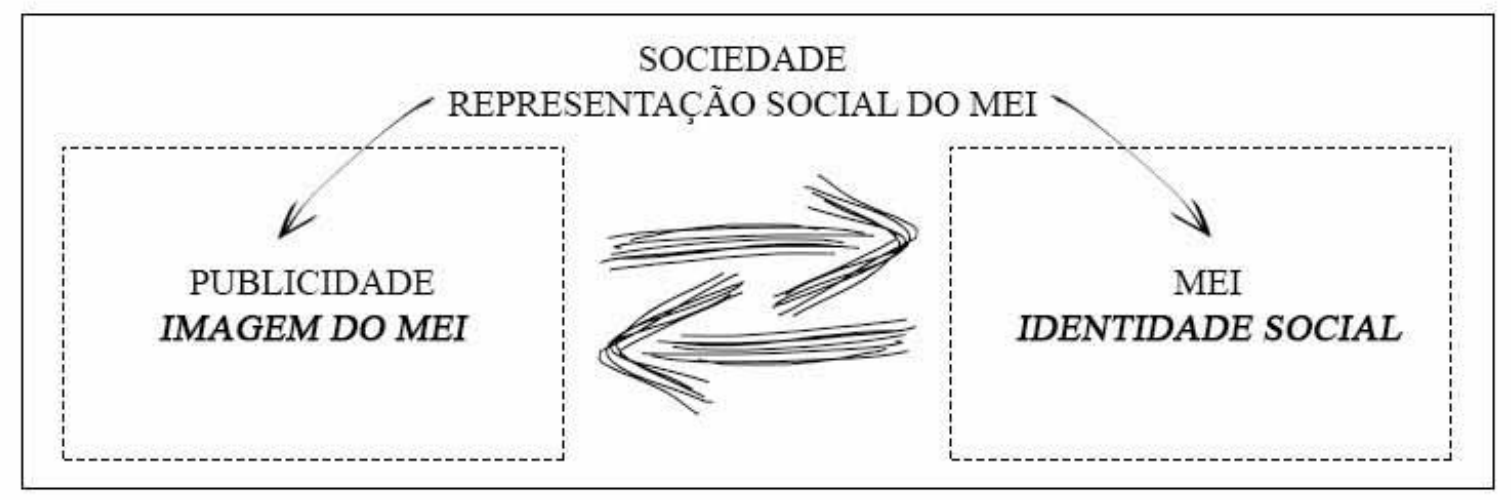

Fonte: elaborado pela autora

Com a apresentação do quadro que resume a dinâmica entre a representação social do microempreendedor individual, sua imagem na publicidade do Sebrae e a identidade social do público-alvo das campanhas, encerra-se a fundamentação teórica do trabalho e é possível dar continuidade à investigação com a apresentação de seus objetivos, procedimentos metodológicos e com a análise do corpus de pesquisa. 


\section{III - OBJETIVOS}

\section{OBJETIVOS DE PESQUISA}

\subsection{Geral}

- Identificar a representação social do microempreendedor individual (MEI) nas campanhas publicitárias veiculadas pelo Sebrae nacionalmente, entre 2009 e 2014.

\subsection{Específicos}

- Analisar a imagem do microempreendedor individual na publicidade da entidade.

- Investigar processos de identificação deflagrados pela publicidade do Sebrae, no que diz respeito ao MEI. 


\section{IV - PROCEDIMENTOS METODOLÓGICOS}

\section{UMA ABORDAGEM PLURI-METODOLÓGICA}

Conhecer a representação social do microempreendedor individual nas campanhas publicitárias veiculadas pelo Sebrae consiste no principal objetivo desta investigação. Para isso, a fundamentação teórica apresentada tem como fio condutor a teoria das representações sociais. Aliada a ela estão os conhecimentos sobre o processo comunicacional, a publicidade e a identidade.

Sobre o estudo das representações sociais, Almeida (2005, p. 124 e 125) afirma que, além de investigar o que os indivíduos pensam e por que pensam de determinada forma acerca de um tema, é preciso também compreender como esse pensamento é construído. Santos (2005, p. 35), por sua vez, defende a importância de conhecer os processos de ancoragem e objetivação da representação, enquanto Moscovici (2012, p. 40) afirma que é preciso desvendar a característica incomum que motivou determinada representação social. No caso do microempreendedor individual, a própria criação arbitrária da figura jurídica, incluindo sua nomenclatura, constitui a característica incomum que dá início ao fenômeno. Antes de 2009, a categoria empresarial não existia e o empresário que trabalhava por conta própria, dentro dos critérios estabelecidos pela legislação vigente, era denominado simplesmente "dono de empresa" ou "empresário". Essa nomenclatura era utilizada para designar, de forma geral, qualquer empreendedor cujo negócio era formalizado.

Assim, compreender que as representações sociais criam e recriam, em um processo dialético, o mundo onde vivemos, permite-nos avaliar seu poder de influência no "comportamento do indivíduo participante de uma coletividade".

Jodelet e Sá (Apud ALMEIDA, 2005, p. 128 e 129) buscam traçar os caminhos metodológicos para atingir esses objetivos. Ambos destacam a necessidade de

apreender os discursos dos indivíduos e dos grupos que mantêm a representação de um dado objeto; apreender os comportamentos e as práticas sociais através das quais essas representações se manifestam; examinar os documentos e registros, onde estes discursos, práticas e comportamentos são institucionalizados; examinar as interpretações que eles recebem nos meios de comunicação de massa, os quais contribuem tanto para manutenção como para a transformação das representações. 
Todas essas diferentes perspectivas de análise transformam as pesquisas sobre representações sociais em investigações pluri-metodológicas (SANTOS, 2005; ALMEIDA, 2005), incluindo aquela proposta neste trabalho e apresentada a seguir.

\subsection{A hermenêutica de profundidade}

O referencial metodológico elaborado pelo sociólogo John B. Thompson (1995, p. 355) e denominado hermenêutica de profundidade (HP), tem como foco principal analisar formas simbólicas, incluindo aquelas que circulam através dos meios de comunicação de massa. A proposta de Thompson não pretende substituir os procedimentos metodológicos já existentes, mas permitir que vários desses procedimentos sejam organizados e aplicados de forma coerente, levando em consideração a complexidade dos fenômenos analisados (Id., p. 356). Pressupõe, ainda, que esses fenômenos são construídos por meio de interações sociais e devem ser interpretados.

A palavra hermenêutica deriva de Hermes que, na mitologia grega, era o mensageiro dos deuses, traduzindo seus desejos e ordens aos humanos (RUSSELL, 2002, p. 449). A interpretação torna-se, assim, elemento-chave para o referencial metodológico, "pois somente desse modo poderemos fazer justiça ao caráter distintivo do campo-objeto" (THOMPSON, 1995, p. 355).

Além disso, o método hermenêutico de investigação exige do pesquisador grande proximidade com o objeto de estudo, pois a interpretação somente será possível caso haja familiaridade com o universo pesquisado. Em outras palavras, "você não consegue estabelecer conexão entre os símbolos se você não conhece os símbolos e o que eles devem significar” (RUSSELL, 2002, p. 451). Este configura-se em um dos maiores desafios deste modelo, uma vez que é preciso cautela para que a proximidade do pesquisador não interfira em seu objeto de estudo. No caso deste trabalho, é preciso se aproximar do universo do microempreendedor individual, porém sem chegar tão perto, a ponto de intervir e confundir as percepções deste público acerca da representação social de sua classe empresarial.

Thompson (1995, p. 365) divide a hermenêutica de profundidade em três grandes perspectivas de análise, ou fases, apresentadas não como elementos sequenciais ou hierarquizados, mas sim como espaços complementares de reflexão para a interpretação de fenômenos complexos. Em cada uma das perspectivas adotadas é possível utilizar diversos métodos de pesquisa, como resume a figura 9 a seguir: 
Figura 9 - Formas de investigação hermenêutica

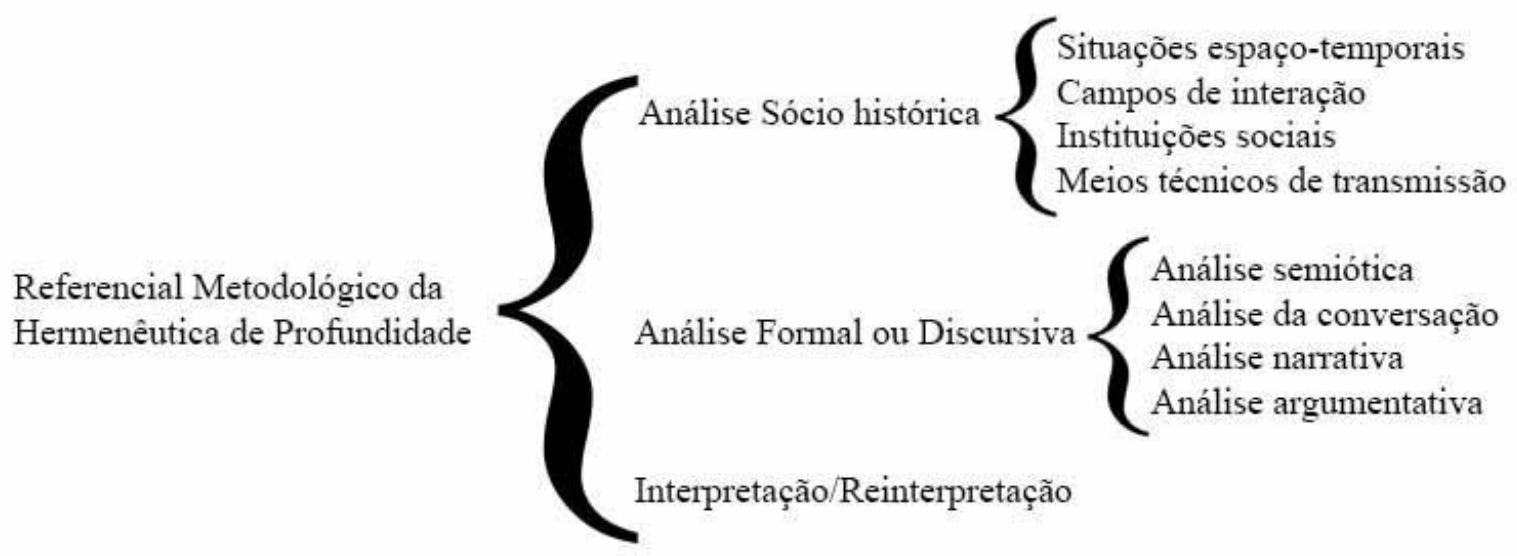

Fonte: THOMPSON, John B. Ideologia e cultura moderna: teoria social crítica na era dos meios de comunicação de massa. Petrópolis, RJ: Vozes, 1995, p. 365.

A primeira fase apresentada pela hermenêutica, a análise sócio histórica, compreende a reconstrução do contexto social e histórico no qual as formas simbólicas são criadas, disseminadas e apropriadas pelos indivíduos: as situações espaço-temporais.

\footnotetext{
As formas simbólicas são produzidas (faladas, narradas, escritas) e recebidas (vistas, ouvidas, lidas) por pessoas situadas em locais específicos, agindo e reagindo a tempos particulares e a locais especiais, e a reconstrução desses ambientes é uma parte importante da análise sócio histórica (Ibid., p. 366).
}

Dois elementos são particularmente importantes na análise sócio histórica, pois dão suporte à discussão sobre a produção e o consumo de formas simbólicas: os campos de interação e as instituições sociais. O primeiro é formado pelos cenários onde ocorrem os fenômenos, e o segundo, pelos agentes que estabelecem as regras das quais derivam os tipos de relações sociais existentes nesses cenários (Ibid., p. 367). Por fim, a análise sócio histórica prevê, também, o estudo dos meios técnicos de construção e disseminação das formas simbólicas, além de sua fruição e das relações que estabelecem com os contextos sociais em que estão inseridos (Ibid., p. 368).

Assim, pode-se afirmar que, neste trabalho, a análise sócio histórica é composta pelas discussões acerca da comunicação, da publicidade, considerando suas funções e seus processos, bem como do Sebrae e, mais especificamente, da figura do MEI. Enquanto a primeira fase da hermenêutica tem como foco o contexto social em que as formas simbólicas estão inseridas, a análise formal direciona a reflexão para as próprias formas simbólicas e suas estruturas (Ibid., p. 369). No caso deste trabalho, lançar mão de diversos métodos de análise definidos a partir 
do próprio objeto de estudo. Alguns exemplos citados por Thompson (Ibid., p. 370) são a análise semiótica, a narrativa e a argumentativa. Nesta investigação, a publicidade do Sebrae será analisada tendo como base os conceitos discutidos durante a fundamentação teórica: as representações sociais, os processos de identificação, a imagem e as funções da linguagem.

Diante do exposto, é possível perceber que a análise formal é apenas uma das perspectivas de análise de um determinado objeto e que, por isso, é necessário que ela esteja inserida num contex to mais amplo de análise, como é justamente o proposto pela hermenêutica:

\begin{abstract}
embora vários tipos de análise formal, estatística e objetiva sejam perfeitamente apropriados e até mesmo vitais de forma geral na análise social, e na análise das formas simbólicas em particular, esses tipos de análise se constituem, na melhor das hipóteses, num enfoque parcial ao estudo dos fenômenos sociais e das formas simbólicas. Eles são parciais porque, como nos lembra a tradição da hermenêutica, muitos fenômenos sociais são formas simbólicas e formas simbólicas são construções significativas que, embora possam ser analisadas pormenorizadamente por métodos formais ou objetivos, inevitavelmente apresentam problemas qualitativamente distintos de compreensão e interpretação (Ibid., p. 358).
\end{abstract}

A última fase proposta pela hermenêutica de profundidade é denominada interpretação ou reinterpretação. Pode-se afirmar que, enquanto as duas primeiras fases da investigação selecionam e identificam os elementos-chave do objeto de estudo, num ato de desconstrução, a interpretação vem construir ou reconstruir esse objeto a partir dos resultados das duas primeiras etapas, trilhando um caminho de síntese em busca de possíveis significados. É o que Thompson denomina de interpretação da doxa, ou seja, interpretação do entendimento cotidiano: as “opiniões, crenças e compreensões que são sustentadas e partilhadas pelas pessoas que constituem o mundo social" (Ibid., p. 375). Em outras palavras, trata-se da produção de sentido no cotidiano, um fenômeno de construção social coletivo que surge das experiências dos indivíduos e também de seus posicionamentos identitários. Spink e Medrado (2004, p. 23) entendem essa dinâmica produtiva "como um fenômeno sociolinguístico - uma vez que o uso da linguagem sustenta as práticas sociais ferradoras de sentido", considerando, também, "a própria variabilidade e polissemia que caracterizam os discursos" (Id., 2004, p. 29).

Ao interpretar o entendimento cotidiano, que por si só já é uma interpretação, Thompson considera que a terceira fase da hermenêutica é, na verdade, uma reinterpretação. Note-se que os termos utilizados pelo autor estão diretamente relacionados àqueles empregados por Moscovici, ao apresentar a teoria das representações sociais. A doxa, ou seja, a vida cotidiana, está relacionada à familiaridade e ao senso comum trabalhados por Moscovici. A dinâmica de compartilhamento existente por meio da coletividade é a questão chave defendida por esses 
autores. A comunicação de massa, por sua vez, é um dos principais atores dentro desse processo. Segundo Spink e Medrado (2004, p. 38),

\begin{abstract}
a mídia assume um papel fundamental na compreensão da produção de sentido, seja porque é pervasiva no mundo contemporâneo e, portanto, instrumental na conformação da consciência moderna, seja porque confere uma visibilidade sem precedentes aos acontecimentos, incluindo aí novas informações e descobertas. Propomos, assim, que a mídia não é apenas um meio poderoso de criar e fazer circular conteúdos simbólicos, mas possui um poder transformador ainda pouco estudado - e, talvez, ainda subestimado - de reestruturação dos espaços de interação propiciando novas configurações aos esforços de produção de sentido.
\end{abstract}

Para conseguir lidar com tamanha subjetividade e complexidade de fenômenos, propõese, para a terceira fase da hermenêutica de profundidade, a realização de entrevistas e grupos focais com diversos atores envolvidos com a comunicação para o microempreendedor individual, além do próprio público das mensagens.

Dinâmica e flexível, a entrevista em profundidade é uma técnica de coleta de dados que permite tratar temas complexos e de natureza íntima do entrevistado (DUARTE, 2012, p. 64), o que se mostra pertinente à investigação proposta. "Em entrevistas em profundidade, a riqueza, a heterogeneidade das respostas é não apenas esperada, como também desejável. Cada respondente apresenta sua visão que pode ter colorido, interpretações, versões diferentes" (Id., p. 81).

Almeida (2005, p. 136), por sua vez, defende a importância da entrevista em estudos sobre representações sociais, considerando-a inclusive como indispensável nesses casos devido a sua capacidade de levantar informações cruciais sobre fenômenos complexos. A entrevista permite ao pesquisador organizar e apresentar informações, percepções e experiências de maneira estruturada. Não se espera obter quantificação ou representatividade estatística com esse tipo de coleta, o que permite maior liberdade na definição da amostra pesquisada. Como afirma Duarte (2012, p. 64),

\footnotetext{
a amostra, em entrevistas em profundidade, não tem seu significado mais usual, o de representatividade estatística de determinado universo. Está mais ligada à significação e à capacidade que as fontes têm de dar informações confiáveis e relevantes sobre o tema de pesquisa.
}

Grupos focais, por sua vez, são entrevistas coletivas realizadas com o objetivo de identificar tendências e valores de referência para um grupo específico (COSTA, 2012, p. 181). Não são indicados para identificar parâmetros populacionais, mesmo aqueles relacionados a atributos pessoais. Em outras palavras, "grupos focais são largamente utilizados para descobrir 
por que as pessoas se sentem como se sentem sobre algo ou as diferentes etapas pelas quais as pessoas tomam determinadas decisões" (RUSSELL, 2002, p. 225). Assim, quando bem orientado, "o grupo focal [...] permite a reflexão sobre o essencial sentido dos valores, dos princípios e motivações que regem os julgamentos e percepções das pessoas" (COSTA, 2012, p.180).

Em resumo, pode-se dizer que entrevistas e grupos são estratégias comumente empregadas porque permitem identificar como ocorre a interpretação das formas simbólicas por aqueles que as produzem e as consomem em diversas esferas do mundo social (THOMPSON, 2005, p. 363 e 364). Essa forma de coleta de dados estimula, "a todo momento, [...] os participantes à produção de sentido" (SPINK; MEDRADO, 2004, p. 25 e 26). Neste trabalho, a interpretação da doxa irá utilizar entrevistas em profundidade e grupos focais tanto com o público consumidor da comunicação do Sebrae, ou seja, o microempreendedor individual, quanto com o produtor dessa comunicação: profissionais da área de marketing e comunicação da entidade e agências publicitárias criadoras das campanhas.

A pesquisa qualitativa permite analisar aspectos como a satisfação e a percepção dos receptores de mensagens disseminadas por meios de comunicação de massa (SANTAELLA, 2001, p. 182). Ela privilegia a interpretação, e não a mensuração (Id., p. 144), no sentido de conhecer o espectro de opiniões a respeito do objeto estudado (GASKELL, 2011, p. 68). Assim, esta pesquisa busca validar seus resultados não por meio da legitimação de seus instrumentos de coleta de dados, mas sim pela qualidade da informação apreendida. Ao investigar fenômenos complexos, aspectos como a generalização dos resultados ou o tamanho da amostra não devem ser tratados sob a ótica positivista, já que valorizar a condição instrumentalista na pesquisa qualitativa torna-se um risco (GONZÁLEZ REY, 2005, p. 3). Em outras palavras, é possível e preciso legitimar o "singular como instância de produção do conhecimento científico" (Id., p. 10).

Ao abordar especificamente a comunicação de massa, Thompson (Ibid., p. 392) traz para a hermenêutica de profundidade o que ele denomina "enfoque tríplice": uma aproximação das formas simbólicas mediadas a partir de três perspectivas distintas. A primeira trata da produção e disseminação das mensagens e deve ser estudada por meio da análise sócio histórica. A segunda, por sua vez, utiliza-se da análise formal e trata do principal produto da comunicação de massa: a mensagem em si, sua construção simbólica e estruturação. A terceira aborda a recepção da mensagem comunicativa, ou seja, foca-se no público-alvo e é trabalhada por meio da interpretação. 
Diante do exposto, é pertinente reapresentar o referencial metodológico da hermenêutica de profundidade, dessa vez adaptado à investigação apresentada neste trabalho (ver figura 10).

Figura 10 - Investigação hermenêutica desta pesquisa

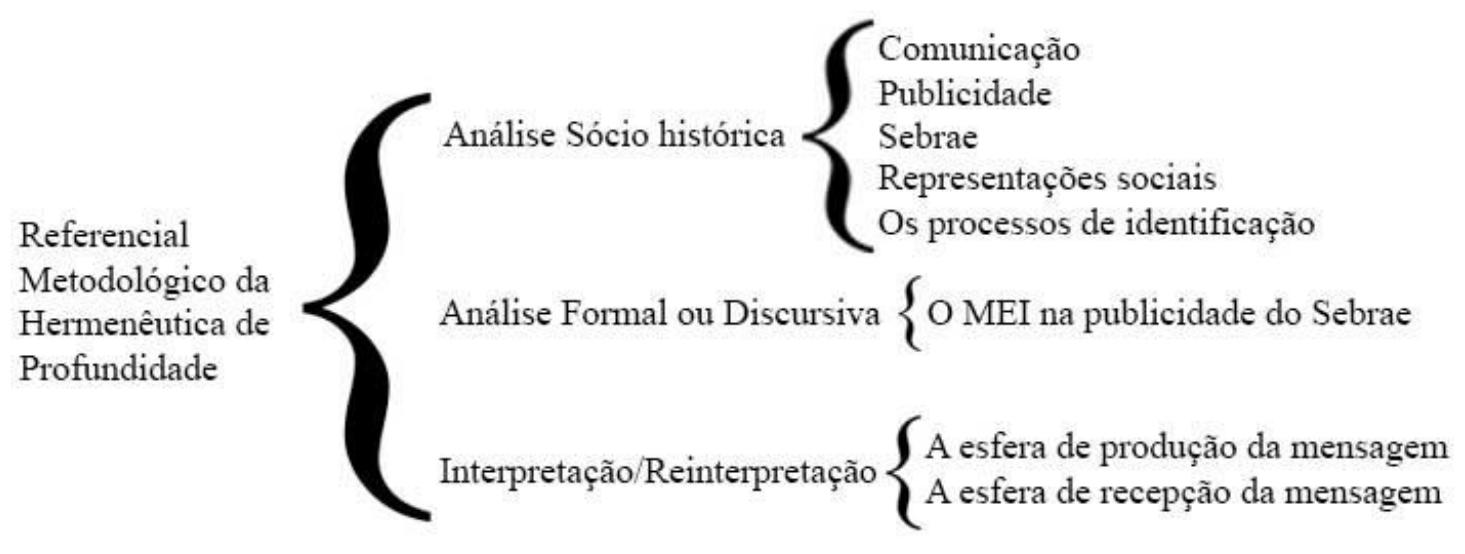

Fonte: elaborado pela autora

Assim, é possível perceber, de forma mais clara, como cada etapa da investigação foi organizada e o trabalho, conduzido, o que permite também iniciar a análise do corpus de pesquisa. 


\section{V - COLETA DE DADOS E DISCUSSÃO DE RESULTADOS}

\section{QUEM É O MEI NA PUBLICIDADE DO SEBRAE?}

Baseados na fundamentação teórica desta investigação, os próximos capítulos apresentam a análise das campanhas publicitárias do Sebrae direcionadas ao microempreendedor individual entre 2009 e 2014 e analisam os contextos de produção e de recepção das mesmas.

\subsection{Análise de imagens}

Normalmente, pesquisas nas áreas de publicidade e marketing - tanto pesquisas de mercado, quanto investigações acadêmicas - analisam imagens para buscar ou verificar sua influência na efetividade das mensagens. Que perguntas devem ser feitas durante a análise de uma imagem? As alternativas são inúmeras, como exemplifica Bergström (2009, p. 124 e 161):

\footnotetext{
De que trata a imagem? Como ela é construída? Em que contexto ela é exibida? A quem se destina? Quem é o emissor? Qual seu propósito? Que papel o cliente espera que a imagem cumpra? Informar, ilustrar, mostrar, explicar, ensinar, assustar, entreter? Quebrar o ritmo, convencer, persuadir, vender? Mudar atitudes, transmitir emoções fortes?
}

Para começar a respondê-las, o presente trabalho analisará as imagens presentes nos anúncios publicitários do Sebrae obedecendo ao roteiro descrito na tabela 6. O roteiro é guiado por estratégias e conceitos apresentados anteriormente, em especial a teoria das representações sociais. 
Tabela 6 - Roteiro para análise de imagens publicitárias do MEI na comunicação do Sebrae

\begin{tabular}{|c|l|}
\hline ORDEM & \multicolumn{1}{|c|}{ AÇÃO } \\
\hline \hline $\mathbf{1}^{\mathbf{a}}$ & Descrever a imagem \\
\hline $\mathbf{2}^{\mathbf{a}}$ & Classificar a mensagem publicitária e a imagem apresentadas na peça \\
\hline $\mathbf{3}^{\mathbf{a}}$ & Identificar as funções da linguagem presentes na peça \\
\hline $\mathbf{4}^{\mathbf{a}}$ & Analisar a representação social do MEI, sua ancoragem e objetivação \\
\hline $\mathbf{5}^{\mathbf{a}}$ & Avaliar a complementaridade entre a imagem e o texto do anúncio \\
\hline $\mathbf{6}^{\mathbf{a}}$ & Trabalhar os possíveis processos de identidade deflagrados pela imagem \\
\hline
\end{tabular}

Fonte: elaborado pela autora

A descrição, primeira ação prevista na análise das imagens, constitui etapa basilar da análise, uma vez que transforma a linguagem visual percebida em linguagem verbal (JOLY, 2012, p. 72). A diversidade de significados que pode surgir a partir da simples descrição é fascinante, em especial quando a ação é realizada em grupo. A partir da descrição já é possível vislumbrar aspectos interpretativos pessoais e coletivos, além do contexto cultural de onde surge a análise. Joly define esse processo como a passagem do "percebido" ao "nomeado".

Da mesma maneira que o emissor da mensagem realiza escolhas ao produzi-la, o receptor, ao verbalizar uma mensagem visual, ou seja, ao descrevê-la, também escolhe determinadas perspectivas de análise antes mesmo de interpretar a mensagem.

\footnotetext{
A publicidade é um bom exemplo dessa conduta. Quer-se mostrar determinada pessoa, determinado traje, determinado lugar em particular, ou ainda evocar determinado conceito (a liberdade, a feminilidade). Encontrar o equivalente visual de um projeto verbal não é simples e requer escolhas de todos os tipos. Um mesmo roteiro (verbal) pode dar lugar a todos os tipos de representações visuais vinculadas à riqueza infinita da experiência de cada um (Id., p. 73).
}

Por fim, a autora apresenta duas maneiras de se descrever uma imagem. A primeira apreende seu significado como um todo, aquele de toda a mensagem, para depois fragmentá-la, identificando quais elementos - ou combinações de elementos - estão associados ao significado produzido. A segunda se dá justamente pelo processo inverso, ou seja, lista-se os elementos identificados na mensagem relacionando seus significados para, depois, ampliar a perspectiva e descobrir o sentido da mensagem como um todo. 
Esta primeira fase da análise das imagens traz, também, uma questão importante: a descrição das características físicas dos modelos nas peças, em especial no que diz respeito a cor da pele ou raça. Para guiar a investigação nesse sentido foi utilizada como referência a classificação descrita pelo Instituto Brasileiro de Geografia e Estatística (IBGE), que divide a população brasileira em brancos, negros, pardos, amarelos e indígenas desde o censo demográfico de 1991 (PETRUCCELLI; SABOIA, 2013, p. 24). Essa mesma classificação foi utilizada por Alberto Carlos Almeida, em sua pesquisa social brasileira, cujos resultados são apresentados no livro "A cabeça do brasileiro" (2007). Como não é objetivo deste trabalho discutir sobre percepção acerca de raça e cor, a categorização proposta pelo IBGE mostra-se suficiente para atender às necessidades da pesquisa, lembrando também que a classificação apresentada aqui reflete unicamente a percepção da pesquisadora e que essa percepção é, obviamente, passível de questionamentos.

Assim, após descrever a peça, é possível avançar para a segunda etapa da análise, onde são classificadas as mensagens publicitárias e as imagens presentes em cada anúncio, de acordo com as categorias definidas por Bergström (2009, p. 64 e 124). Segundo o autor, as mensagens publicitárias podem ser instrumentais, relacionais ou testemunhais.

A mensagem instrumental explicita uma suposta necessidade do receptor que pode ser satisfeita pelo produto ou serviço vendido. "Os argumentos que constroem essas mensagens devem ser racionais, e a técnica narrativa deve ser fechada para que haja apenas uma possibilidade interpretativa" (Ibid., p. 64). A mensagem relacional, por sua vez, utiliza-se de argumentos emocionais para persuadir o público-alvo, relacionando o produto ou serviço vendido à sensação de bem-estar ou, ainda, de pertencimento a determinado grupo. Bergström descreve a mensagem relacional como aquela que faz o receptor sonhar, enquanto a mensagem instrumental o faz despertar. Por fim, tem-se a mensagem publicitária testemunhal, que se apoia na figura de um indivíduo para auxiliar no processo de convencimento.

\footnotetext{
Na publicidade, o emissor pode usar o depoimento de uma testemunha para ajudar o receptor na agonia da escolha referente a bens e serviços [...] Muitas vezes, os gerentes de publicidade colocam pessoas comuns, de preferência os próprios consumidores, em documentários e textos assertivos para conferir credibilidade e legitimidade às mensagens (Ibid., p. 66).
}

Já as imagens são classificadas em informativas, explicativas, diretivas ou expressivas. A imagem informativa "passa uma informação relevante sem juízo de valor" (Ibid., p. 124) e está presente principalmente na imprensa, ou ainda em catálogos de venda (impressos ou eletrônicos). A imagem explicativa, segundo Bergström, esclarece um determinado 
acontecimento ou instrui uma ação. Imagens presentes em instruções de montagem de determinado produto são consideradas imagens explicativas. Imagens diretivas, por sua vez, são aquelas que encorajam determinada opinião e são utilizadas quando o emissor quer influenciar o receptor. A imagem publicitária é, normalmente, uma imagem diretiva. Por fim, tem-se as imagens expressivas, que não obedecem a regras ou convenções e são, portanto experimentais e pessoais. Independentemente de sua classificação, "uma imagem representativa é usada quando o emissor quer ilustrar, apresentar ou mostrar com o que alguma coisa se parece e salientar determinadas características. Estamos constantemente cercados por esse tipo de imagem" (Ibid., p. 127).

A terceira etapa da análise corresponde à identificação das funções da linguagem presentes em cada peça analisada, resgatando as definições apresentadas anteriormente. Em seguida, propõe-se a reflexão sobre a representação social do microempreendedor individual presente no anúncio. Ao trabalhar com a perspectiva da intenção, o anunciante (neste caso, o Sebrae) considera os objetivos da mensagem e seu contexto de recepção, fatos que influenciam a produção daquele conteúdo e, consequentemente, a escolha da imagem do anúncio (Ibid., p. 124). Entram em cena, nesse processo, os mecanismos de ancoragem e objetivação, pois é preciso classificar o MEI e objetivá-lo, ou seja, concretizá-lo em uma imagem para ser reconhecido pelo público-alvo e, assim, ser comunicado.

Antes de avaliar os possíveis processos de identificação deflagrados por cada uma das imagens, última etapa da análise baseada nas reflexões de Tajfel e no modelo de Burke e Stets, é analisada a complementaridade entre imagem e texto nos anúncios. É importante que essa questão seja considerada, uma vez que a imagem publicitária dificilmente está sozinha ao ser consumida. Ela está inserida em um contexto, inclusive o contexto do próprio anúncio, que a influencia e é influenciado por ela. "É lá, junto de outras imagens, títulos, introduções, colunas, legendas e logotipos, que a imagem desempenha seu papel na transmissão das mensagens" (Ibid., p. 134). Assim como Bergström, Kossoy (2002, p. 54 e 55) também destaca a influência do texto no significado das imagens. Para o autor, elas são vulneráveis aos títulos e legendas que recebem nos leiautes. Assim, uma mesma foto pode adquirir significados distintos, e até mesmo antagônicos, "através, simplesmente [...] da mera invenção de uma nova legenda ou título" (Id.).

É importante destacar a escolha pela utilização do termo "complementaridade". O presente trabalho busca não estabelecer hierarquia entre os elementos da mensagem visual, mas sim destacar seu funcionamento conjunto para a conquista de um objetivo em comum: comunicar eficazmente. Assim, as palavras conseguem dizer o que a imagem não pode mostrar, 
e vice-versa (JOLY, 2012, p. 119). Essa postura resgata a importância da imagem frente à escrita, tida historicamente como mais importante.

Bergström (2009, p. 222) chama atenção, ainda, para duas características conflitantes das imagens: a primeira é a capacidade que têm de serem apreendidas facilmente, visto que se parecem com aquilo que buscam representar; a segunda é a liberdade para a interpretação de seus significados, sendo considerada a possibilidade de o receptor interpretar a mensagem de maneiras distintas daquela pretendida pelo emissor. "As experiências tornam-se muito pessoais - pessoais demais" (Id., p. 222) e isso, para o autor, caracteriza a fraqueza das imagens. O caráter pessoal despertado por elas é parte do processo de interpretação das mesmas. As experiências de vida, conhecimentos e crenças do público influenciam essa dinâmica, como já discutido anteriormente.

Não há consenso sobre as características das imagens defendidas por Bergström. Nem sempre as imagens são de fácil compreensão, embora esse não seja o objetivo da imagem utilizada na publicidade. Além disso, diferentes aspectos do receptor podem influenciar a liberdade de interpretação mencionada pelo autor. O nível de instrução, o estilo cognitivo e os traços da personalidade são alguns deles. Joly (2012, p. 108), por sua vez, não rotula a característica polissêmica da imagem como algo negativo, porém concorda com o autor ao afirmar que a mensagem linguística auxilia a interpretação, direcionando o processo.

\footnotetext{
Uma boa combinação de texto e imagem tem a capacidade de contar uma história atraente, ultrapassando em larga escala o que qualquer uma das duas linguagens atingiria sozinha. De forma bem simples, o efeito é reforçar a mensagem, pois o elemento verbal e intelectual está unido ao visual e emocional. O emissor, portanto, tirará proveito das semelhanças e diferenças, das forças e fraquezas, de ambas as linguagens (BERGSTRÖM, 2009, p. 223).
}

Para Bergström, a mensagem eficaz é aquela que incentiva a participação do receptor, convidando-o a desvendá-la. Esse efeito é conseguido ao se utilizar imagem e texto que comunicam coisas diferentes. A dissonância entre esses elementos gera uma dinâmica que amplia o significado da mensagem. As histórias em quadrinhos, onde os balões de texto e as imagens comumente não comunicam o mesmo conteúdo, mas se complementam, são um exemplo apresentado pelo autor ao defender sua preferência por essa estratégia de construção da mensagem visual. Para ele, a redundância da mensagem gerada por uma imagem e um texto que comunicam a mesma coisa é desperdício de recursos. A mensagem fica prolixa e seu potencial significante não é explorado. "O receptor forma rapidamente a mensagem 
superexplícita sem o menor esforço, e basta. Chamaremos isso de sobrecomunicação, que torna o receptor passivo" (Id., p. 224).

Ao discutir a complementaridade entre imagem e texto na publicidade do Sebrae, espera-se identificar como essa relação se estabelece, ou seja, se o significado da mensagem é expandido por imagem e texto que apresentam conteúdos diferentes, ou se há redundância nas mensagens transmitidas por esses elementos. Essa sexta etapa encerra o processo de análise das imagens publicitárias, concluindo também a segunda fase da hermenêutica de profundidade, a análise formal.

\subsection{O microempreendedor individual na publicidade do Sebrae}

Um dos aspectos mais comuns ao realizar análise de imagens é justamente aquele que diz respeito à sua capacidade de comunicação (COUTINHO, 2012, p. 330 e 331). A pergunta “o que está sendo comunicado?” é feita com bastante frequência em investigações sobre os meios de comunicação de massa. Como afirma Joly (2012, p. 69), “entre as imagens mais propícias à análise estão as de publicidade”.

A autora defende também que o pesquisador deve se colocar na posição do receptor ao realizar análise de imagens. "Uma das precauções necessárias para compreender da melhor forma possível uma mensagem visual é buscar para quem ela foi produzida" (Id., p. 55). Além disso, outro ponto fundamental da análise é definir seu objetivo, pois é impossível estudar uma imagem se não há propósito claro, se não se sabe por que estudá-la. A análise, portanto, “deve servir a um projeto, e é este que vai dar sua orientação, assim como permitirá elaborar sua metodologia. Não existe um método absoluto para análise” (Ibid., p. 54).

Para definir o corpus de pesquisa e determinar quais imagens seriam analisadas, foram elencadas todas as campanhas do Sebrae voltadas para o MEI entre 2009 e 2014, num total de 18, conforme demonstra a tabela 7 : 
Tabela 7 - Campanhas criadas e veiculadas pelo Sebrae para o MEI entre 2009 e 2014

\begin{tabular}{|c|c|c|}
\hline ANO & AGÊNCIA & CAMPANHA \\
\hline 2009 & Giacometti & Chegou a sua vez \\
\hline \multirow{4}{*}{2010} & \multirow{2}{*}{ Giacometti } & Empreendedor Individual \\
\hline & & Kit Rádio Empreendedor \\
\hline & \multirow{2}{*}{ Lew’LaralTBWA } & Ei. Tá na hora de se formalizar \\
\hline & & Semana do Empreendedor Individual \\
\hline \multirow{3}{*}{2011} & \multirow{3}{*}{ Lew'LaralTBWA } & 1 Milhão \\
\hline & & Declaração Anual \\
\hline & & Semana do Empreendedor Individual \\
\hline \multirow{5}{*}{2012} & \multirow{5}{*}{ Giacometti } & Declaração Anual Simplificada de 2011 \\
\hline & & Inadimplência \\
\hline & & $4^{\mathrm{a}}$ Semana do Empreendedor Individual \\
\hline & & Sebrae Empreendedor \\
\hline & & Sebrae 40 Anos \\
\hline \multirow{3}{*}{2013} & Giacometti & MEI Card \\
\hline & \multirow{2}{*}{ Lew'LaralTBWA } & Folder SEI \\
\hline & & Semana do Microempreendedor Individual \\
\hline \multirow{2}{*}{2014} & Giacometti & Sebrae Apresenta \\
\hline & Lew'Lara\TBWA & Semana do Microempreendedor Individual \\
\hline
\end{tabular}

Fonte: listagem elaborada pela autora a partir de material fornecido pelo Sebrae

Para esta investigação, optou-se por analisar aquelas peças que apresentam imagens do microempreendedor individual, excluindo, assim, qualquer leiaute all type,, ou seja, composto apenas por textos e outros elementos gráficos. Ambas as agências disponibilizaram o material por meio de CD. A partir do critério estabelecido, foram identificados 57 materiais que continham imagens representativas do MEI, entre anúncios, filmes, cartazes e folders e, dentre esses, um total de vinte e uma imagens diferentes, conforme detalhamento apresentado na tabela 8 abaixo: 
Tabela 8 - Critérios de seleção das campanhas analisadas na investigação (continua)

\begin{tabular}{|c|c|c|c|}
\hline ANO & AGÊNCIA & CAMPANHA & ANÁLISE \\
\hline 2009 & Giacometti & Chegou a sua vez & Analisada \\
\hline \multirow{4}{*}{2010} & \multirow[b]{2}{*}{ Giacometti } & Empreendedor Individual & Analisada \\
\hline & & Kit Rádio Empreendedor & $\begin{array}{l}\text { Sem imagens representativas } \\
\text { do MEI }\end{array}$ \\
\hline & \multirow[b]{2}{*}{ Lew'LaralTBWA } & Ei. Tá na hora de se formalizar & Analisada \\
\hline & & $\begin{array}{l}\text { Semana do Empreendedor } \\
\text { Individual }\end{array}$ & $\begin{array}{l}\text { Reutilização de imagens } \\
\text { (mesmo casal da campanha } \\
\text { "Ei. Tá na hora de se } \\
\text { formalizar") }\end{array}$ \\
\hline \multirow{3}{*}{2011} & \multirow{3}{*}{ Lew'LaralTBWA } & 1 Milhão & Analisada \\
\hline & & Declaração Anual & $\begin{array}{l}\text { Sem imagens representativas } \\
\text { do MEI }\end{array}$ \\
\hline & & $\begin{array}{l}\text { Semana do Empreendedor } \\
\text { Individual }\end{array}$ & $\begin{array}{l}\text { Reutilização de imagens } \\
\text { (mesmo casal da campanha "1 } \\
\text { Milhão") }\end{array}$ \\
\hline \multirow{5}{*}{2012} & \multirow{5}{*}{ Giacometti } & $\begin{array}{l}\text { Declaração Anual Simplificada de } \\
2011\end{array}$ & $\begin{array}{l}\text { Sem imagens representativas } \\
\text { do MEI }\end{array}$ \\
\hline & & Inadimplência & $\begin{array}{l}\text { Reutilização de imagens } \\
\text { (mesmo casal da campanha } \\
\text { "Ei. Tá na hora de se } \\
\text { formalizar") }\end{array}$ \\
\hline & & $\begin{array}{l}4^{a} \text { Semana do Empreendedor } \\
\text { Individual }\end{array}$ & $\begin{array}{l}\text { Reutilização de imagens } \\
\text { (mesmo homem da campanha } \\
\text { "1 Milhão") }\end{array}$ \\
\hline & & Sebrae Empreendedor & Analisada \\
\hline & & Sebrae 40 Anos & Analisada \\
\hline
\end{tabular}


Tabela 8 - Critérios de seleção das campanhas analisadas na investigação (conclusão)

\begin{tabular}{|c|c|c|c|}
\hline \multirow{3}{*}{2013} & Giacometti & MEI Card & Analisada \\
\hline & \multirow[b]{2}{*}{ Lew'LaralTBWA } & Folder SEI & Analisada \\
\hline & & $\begin{array}{l}\text { Semana do Microempreendedor } \\
\text { Individual }\end{array}$ & $\begin{array}{l}\text { Sem imagens representativas } \\
\text { do MEI }\end{array}$ \\
\hline \multirow[b]{2}{*}{2014} & Giacometti & Sebrae Apresenta & Analisada \\
\hline & Lew'LaralTBWA & $\begin{array}{l}\text { Semana do Microempreendedor } \\
\text { Individual }\end{array}$ & $\begin{array}{l}\text { Sem imagens representativas } \\
\text { do MEI }\end{array}$ \\
\hline
\end{tabular}

Fonte: elaborado pela autora

É importante lembrar que, até 2012, toda a comunicação direcionada ao MEI - seja do Sebrae, do governo federal ou de outros anunciantes - suprimia a palavra "micro", utilizando apenas o termo "empreendedor individual". Essa decisão foi tomada com base nas pesquisas com empreendedores informais antes da regulamentação da lei, quando se verificou a conotação pejorativa da sigla MEI, conforme apresentado no início deste trabalho. A partir de 2013, no entanto, passa-se a utilizar em toda a comunicação, inclusive a do Sebrae, a nomenclatura e sigla completas, ou seja, microempreendedor individual e MEI, como está designado na legislação. Além disso, o valor de faturamento anual da figura jurídica sofreu alterações desde a sua criação: passou de 30 para 60 mil reais anuais, informação refletida nas campanhas de acordo com o ano de sua veiculação.

Os planos de mídia apresentados à pesquisadora pelas agências, por sua vez, não permitem vincular cada uma das peças a um veículo de mídia específico, mas apenas ao tipo de mídia para o qual ela foi criada. Por fim, os briefings das campanhas não foram analisados porque o Sebrae não tem o costume de elaborá-los em forma de documento escrito. Os briefings das campanhas são, normalmente, repassados às agências durante reuniões. Às vezes, uma apresentação em PowerPoint auxilia o repasse das informações.

Após essas considerações, é possível seguir com a análise das vinte e uma imagens representativas do microempreendedor individual presentes em peças publicitárias do Sebrae entre os anos de 2009 e 2014, apresentadas nas figuras 11 e 31. 


\subsubsection{Chegou a sua vez - Giacometti 2009}

A campanha "Chegou a sua vez", criada pela agência Giacometti, foi a primeira campanha a tratar da nova pessoa jurídica. Seu principal objetivo era incentivar a formalização, utilizando o mote "Chegou a vez de quem trabalha por conta própria". Serão analisadas duas peças dessa campanha, as duas únicas que apresentam uma imagem representativa do microempreendedor individual.

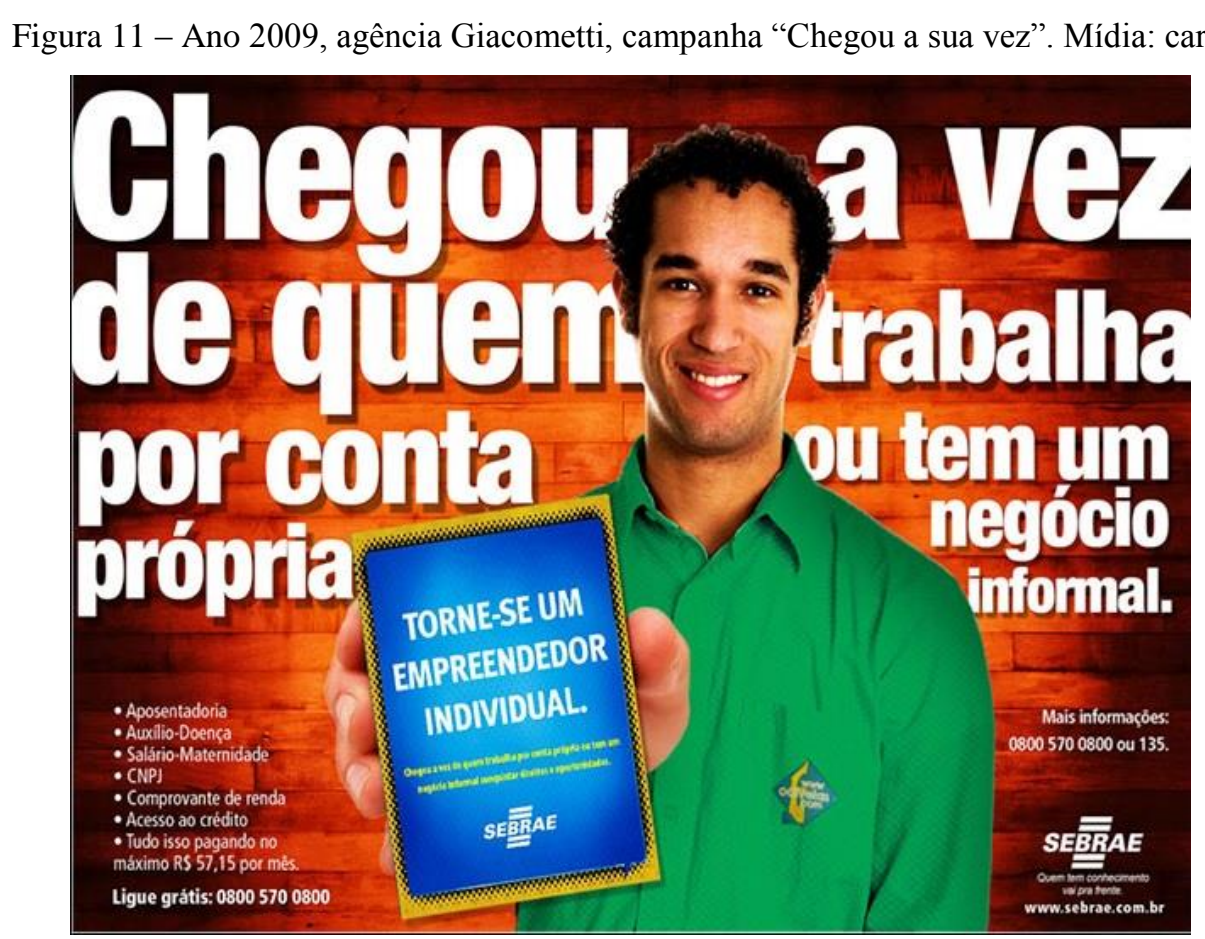

Fonte: material fornecido pela agência Giacometti

A primeira delas é um cartaz (figura 11) e traz a imagem de um rapaz jovem, vestindo camisa social verde e com logotipo de uma empresa, olhando diretamente para a câmera e sorrindo. Ao fundo, há uma parede de tijolos aparentes. Ele segura um folder que apresenta ao receptor, onde se lê: "Torne-se um empreendedor individual. Chegou a vez de quem trabalha por conta própria ou tem um negócio informal conquistar direitos e oportunidades". Logo abaixo, no próprio folder, vê-se a marca do Sebrae. O título do cartaz é posicionado atrás do modelo: "Chegou a vez de quem trabalha por conta própria ou tem um negócio informal". O texto é apresentado em forma de lista, à esquerda do leiaute: "Aposentadoria / Auxílio-Doença / Salário Maternidade / CNPJ / Comprovante de renda / Acesso ao crédito / Tudo isso pagando no máximo R \$ 57,15 por mês. Ligue grátis: 0800570 0800”. À direita do leiaute, o telefone da 
central de relacionamento do Sebrae é repetido: "Mais informações: 08005700800 ou 135". A assinatura está logo abaixo, no canto inferior direito da peça.

A mensagem do cartaz é visivelmente instrumental, de acordo com a categorização proposta por Bergström (2009, p. 64). A estratégia de persuasão utiliza argumentos racionais expostos de forma clara, inclusive apresentando-os em formato de lista. A imagem, por sua vez, é explicativa, pois tem como objetivo mostrar ao receptor que o modelo é um microempreendedor individual. Para conseguir isso, a camisa do rapaz apresenta a logomarca de uma empresa (da qual, provavelmente, ele é o dono). Isso, no entanto, pode ser compreendido dessa forma somente com o apoio do texto do anúncio, que faz referência ao empreendedorismo.

A principal função da linguagem identificada na peça é a conativa, típica das mensagens publicitárias. Embora o título e o texto do anúncio passem informações assertivas acerca dos benefícios da formalização, o que denotaria a função referencial, e o número da central de relacionamento do Sebrae apareça em dois momentos, caracterizando a função fática, a argumentação geral do anúncio tem como propósito a persuasão. $\mathrm{O}$ elemento da peça que demonstra explicitamente a função conativa é identificado no folder mostrado no anúncio, já que utiliza o imperativo e a $2^{\mathrm{a}}$ pessoa verbal, e também no comando "Ligue grátis" presente no texto. Também é identificada a função metalinguística, visto que há ênfase no código da mensagem apresentada. Esse código deve ser comum tanto para o emissor quanto para o receptor, e a imagem busca criar cumplicidade entre eles para comunicar. Além disso, é perceptível a preocupação do emissor em utilizar, no anúncio, elementos já conhecidos pelo receptor da mensagem. O folder, por exemplo, lembra uma carteira de trabalho que, ao ser entregue ao receptor pelo modelo, passa a mensagem de que o empresário não precisa mais dela, pois agora é empreendedor formalizado e não mais empregado de alguém.

Ao analisar a imagem do MEI sob a ótica das representações sociais, é possível afirmar que a ancoragem e a objetivação do conceito ocorrem com base na interação entre diferentes elementos do anúncio. As expressões "trabalha por conta própria", "tem um negócio informal" e "torne-se um empreendedor individual" associam o modelo ao conceito de empresário, parte fundamental da ancoragem, ou seja, da classificação do MEI como dono de um negócio formal. A logomarca presente na camisa do rapaz é o principal elemento para objetivar o conceito apresentado, ou seja, concretizá-lo em forma de imagem e, assim, comunicá-lo. Ao mostrar o folder para a câmera, a ação do modelo busca ativar no receptor da mensagem a imagem mental de um indivíduo decidido e independente, características normalmente associadas ao conceito 
de empresário e, consequentemente, do microempreendedor individual. A camisa social, juntamente com logomarca da empresa, tem o mesmo objetivo.

No entanto, apenas esses elementos gráficos são insuficientes para transmitir o conceito como um todo. A complementaridade entre texto e imagem é basilar para que o cartaz consiga comunicar o conceito de microempreendedor individual e, consequentemente, os benefícios da formalização. É necessária, assim, a associação de imagem e texto para ativar o processo de identificação no receptor da mensagem.

A identificação com o modelo do anúncio ocorrerá caso o receptor da mensagem já seja um microempreendedor individual. Essa identificação elevará sua autoestima como empresário e contribuirá para a manutenção de seu comportamento como tal. Em outras palavras, o público é lembrado que, devido à formalização de seu negócio, ele adquiriu cidadania empresarial e, assim, é estimulado a manter sua situação de legalidade com o pagamento periódico de seus impostos.

Outro cenário possível é aquele em que o receptor da mensagem não se identifica com o modelo, porém vislumbra a possibilidade de ser como ele mediante a formalização de seu negócio. Idealmente, o MEI representado na peça desperta no receptor o desejo por um futuro melhor, no qual seu empreendimento é bem-sucedido e ele tem o apoio do Sebrae para geri-lo, tem direito a aposentadoria, auxílio-doença, licença maternidade etc. Assim, a busca pela formalização é incentivada ao serem evidenciados os aspectos negativos da informalidade. Esse é o principal objetivo da comunicação do Sebrae para o microempreendedor individual.

Ao analisar a segunda peça da campanha "Chegou a sua vez", também é possível observar o incentivo à formalização. Trata-se de uma cartilha (figura 12) que apresenta a figura jurídica do microempreendedor individual e detalha os benefícios da formalidade. 
Figura 12 - Ano 2009, agência Giacometti, campanha "Chegou a sua vez". Mídia: cartilha
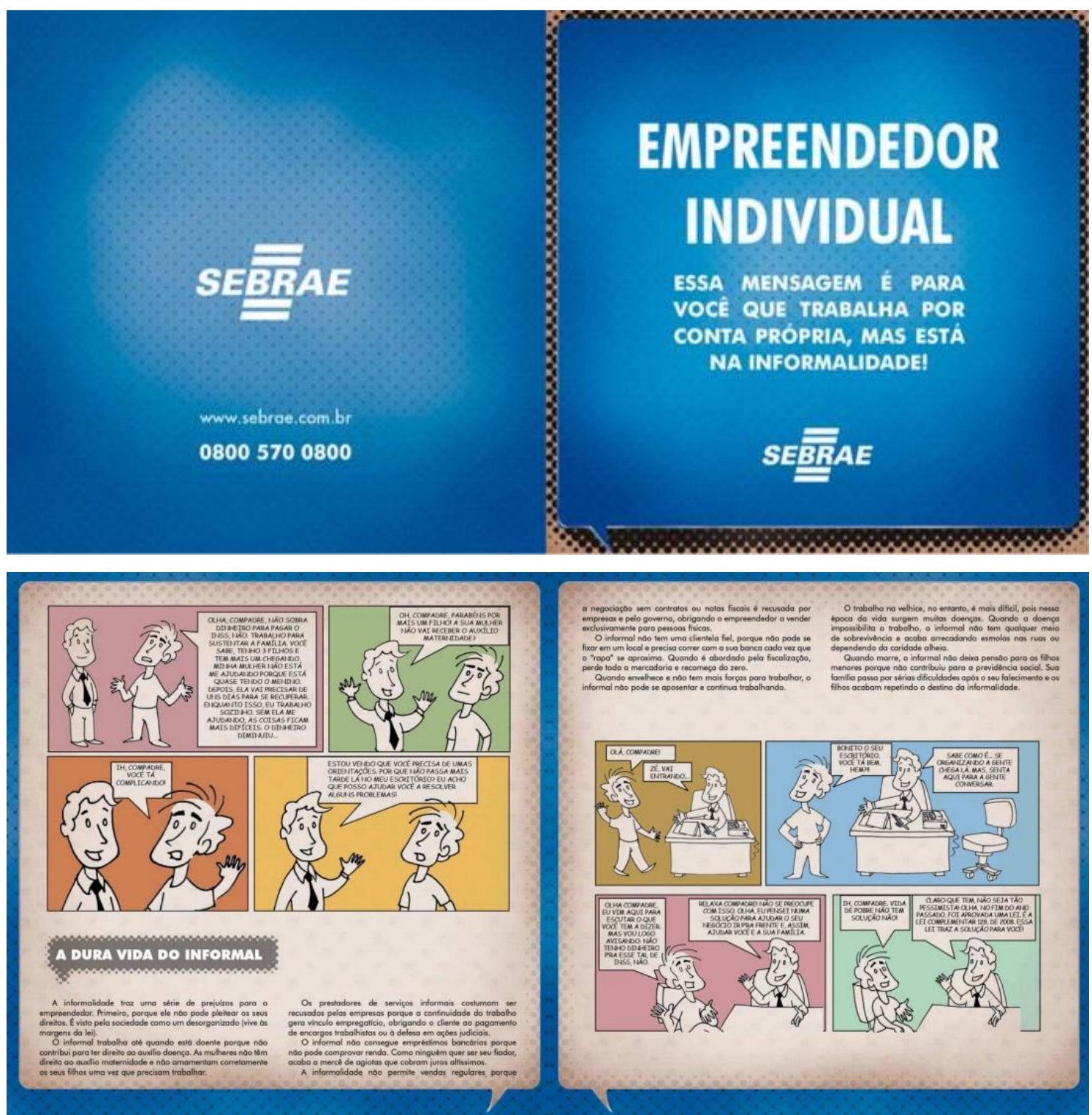

Fonte: material fornecido pela agência Giacometti

A capa da cartilha é azul, seguindo a linha visual da campanha (da qual, curiosamente, o cartaz destoa), e o título e subtítulo são apresentados em branco, ao centro do leiaute e dentro de um balão de diálogo. O texto diz: "Empreendedor Individual. Essa mensagem é para você que trabalha por conta própria, mas está na informalidade!’. Abaixo do texto, mas ainda dentro do balão, é exibida a logomarca do Sebrae. A contracapa segue a mesma linha visual, porém sem o balão de diálogo. A logomarca é apresentada ao centro e logo abaixo está o endereço do Sebrae na internet e o telefone da central de relacionamento com o cliente.

A parte interna da cartilha apresenta o conteúdo de duas formas: por meio de uma história em quadrinhos ilustrada e também por blocos de texto. O balão de diálogo continua 
presente e abarca todo o conteúdo apresentado. A história em quadrinhos traz a conversa entre dois empreendedores: um deles passa por dificuldades financeiras e desabafa com o amigo. A principal queixa gira em torno da esposa, que está grávida de mais um filho e não pode ajudálo com as despesas da casa. O amigo, cuja situação financeira está boa, convida-o para ir até seu escritório e assim conversarem melhor. Ao aparecer por lá, ele é apresentado à figura do microempreendedor individual e aos seus benefícios.

A ilustração mostra o trabalhador informal vestindo camisa e calça, enquanto o amigo bem-sucedido veste uma gravata. O escritório do empresário de sucesso é composto por uma mesa, papéis, canetas, telefone e cadeiras. O desenho não é colorido. Há apenas variações de cores ao fundo dos quadros. Algumas frases ditas pelas personagens são: “Olha, compadre, não sobra dinheiro para pagar o INSS, não. Trabalho para sustentar a família", "Estou vendo que você precisa de umas orientações", "Se organizando a gente chega lá", "Não tenho dinheiro para esse tal de INSS, não", "Vida de pobre não tem solução, não!", "Não seja tão pessimista! Olha, no fim do ano passado, foi aprovada uma lei, é a lei complementar 128, de 2008. Essa lei traz a solução para você!”. O texto que acompanha a história em quadrinhos tem como título "A dura vida do informal" e apresenta diversas desvantagens da informalidade, justamente com a falta dos benefícios previstos ao microempreendedor individual, como auxílio-doença, licença maternidade e CNPJ, entre outros.

Diante do exposto, é possível afirmar que a mensagem apresentada pela cartilha é instrumental, assim como a do cartaz, com argumentos bem definidos e expostos de maneira clara ao receptor. As imagens que acompanham a história em quadrinhos são explicativas, uma vez que buscam representar o trabalhador informal e o microempreendedor individual. Notese, ainda, que em nenhum momento o empresário bem-sucedido é identificado como MEI. Porém, tal condição fica subentendida, assim como fica subentendido que o empreendedor informal, ao se registrar, poderá retomar as rédeas de sua vida financeira e chegar à posição do colega. É interessante o uso deste recurso, uma vez que deixar subentendido que o personagem bem-sucedido é um microempreendedor individual pode direcionar a atenção do público para as desvantagens da informalidade. Em outras palavras, a cartilha argumenta a favor da formalização citando os pontos negativos de empreender informalmente. Outro aspecto curioso da peça é o papel desempenhado pelo MEI. Ele atua como fonte de apoio e informação para melhorar a gestão do negócio do colega, papel esse pertencente ao Sebrae.

Apesar de não apresentar o verbo no imperativo, um dos elementos marcantes da função conativa da linguagem, esta é a principal função presente na peça, uma vez que seu propósito é persuadir o receptor à formalização de seu negócio. A argumentação se dá de maneira objetiva, 
com o emprego do vocativo "você" já na capa da cartilha, e sustenta-se pela exposição dos benefícios aos quais o microempreendedor individual tem direito após a formalização. Outra função da linguagem identificada no texto é a função referencial, uma vez que os benefícios da formalização são apresentados no texto e comparados de maneira incisiva às dificuldades de se viver na informalidade. Além disso, os balões de diálogo caracterizam a função poética, uma vez que enfatizam tanto o conteúdo da comunicação quanto a sua forma, denotando a preocupação do emissor com a estética da mensagem.

No que concerne à representação social do MEI, é possível identificá-lo na peça principalmente pela representação antagônica, ou seja, a representação daquele que não é o microempreendedor individual: o informal. A ancoragem do informal apresenta-se por meio de termos como "pobre" e "pessimista", ou ainda aquele que "precisa de orientações" e "precisa de ajuda para resolver alguns problemas", enquanto o MEI é o empreendedor que "está bem" e é "organizado". O trabalhador informal, ao contrário do microempreendedor individual, "trabalha até quando está doente", "não amamenta corretamente seus filhos", "não consegue empréstimos bancários", "é recusado como prestador de serviços e fornecedor por pessoas jurídicas", "não tem clientela fiel”, "não pode se aposentar" e "não deixa pensão para os filhos após a morte".

A objetivação do conceito é menos explícita: o informal aparece na ilustração de camiseta de manga curta e calça, enquanto o microempreendedor individual veste-se com camisa social, calça e gravata. A empresa física complementa a objetivação, já que o MEI é apresentado em seu escritório, onde há uma mesa com cadeiras, papéis e telefone. Mais uma vez é observada a necessidade de complementaridade entre texto e imagem para a efetividade da comunicação. Não é possível identificar o microempreendedor individual, ou mesmo o trabalhador informal, por meio das ilustrações da cartilha. A gravata e o cenário do escritório podem remeter o receptor ao conceito de empresário, porém não há nenhum indicativo explícito de que aquele personagem é um MEI, nem mesmo no texto dos quadrinhos. A condição de microempreendedor individual do personagem engravatado é subentendida pela maneira como a história é construída e a forma como ambos os personagens são comparados um com o outro: o informal é pobre, não tem futuro e seu negócio está fadado ao fracasso, enquanto o MEI é bem-sucedido e dispõe de benefícios empresariais e sociais. Como a própria história apresenta, ele "está bem".

Como apontado anteriormente, a argumentação a favor da formalização está totalmente baseada nos problemas enfrentados pelos trabalhadores informais. Assim, as categorias sociais do MEI e do empreendedor informal são apresentadas em oposição de forma marcante na peça 
analisada. A comunicação busca ativar no público informal o processo de comparação social com o microempreendedor individual, o que gerará tensão no receptor da mensagem, uma vez que a identificação não ocorrerá. Essa tensão, por sua vez, será o agente da mudança, ou seja, da busca pela formalização, objetivo final do Sebrae.

\subsubsection{Empreendedor Individual - Giacometti 2010}

A segunda campanha analisada, chamada simplesmente de "Empreendedor Individual", também foi criada pela agência Giacometti e veiculada em 2010. O principal objetivo de campanha foi a formalização. Um maior investimento em produção e mídia possibilitou a criação e veiculação de um filme para TV e a realização de duas ações de merchandising na novela I da Rede Globo, Cama de Gato. Outras peças também foram utilizadas, como cartazes, folders e anúncios de revista. Serão analisadas aquelas que trazem imagens representativas do microempreendedor individual.

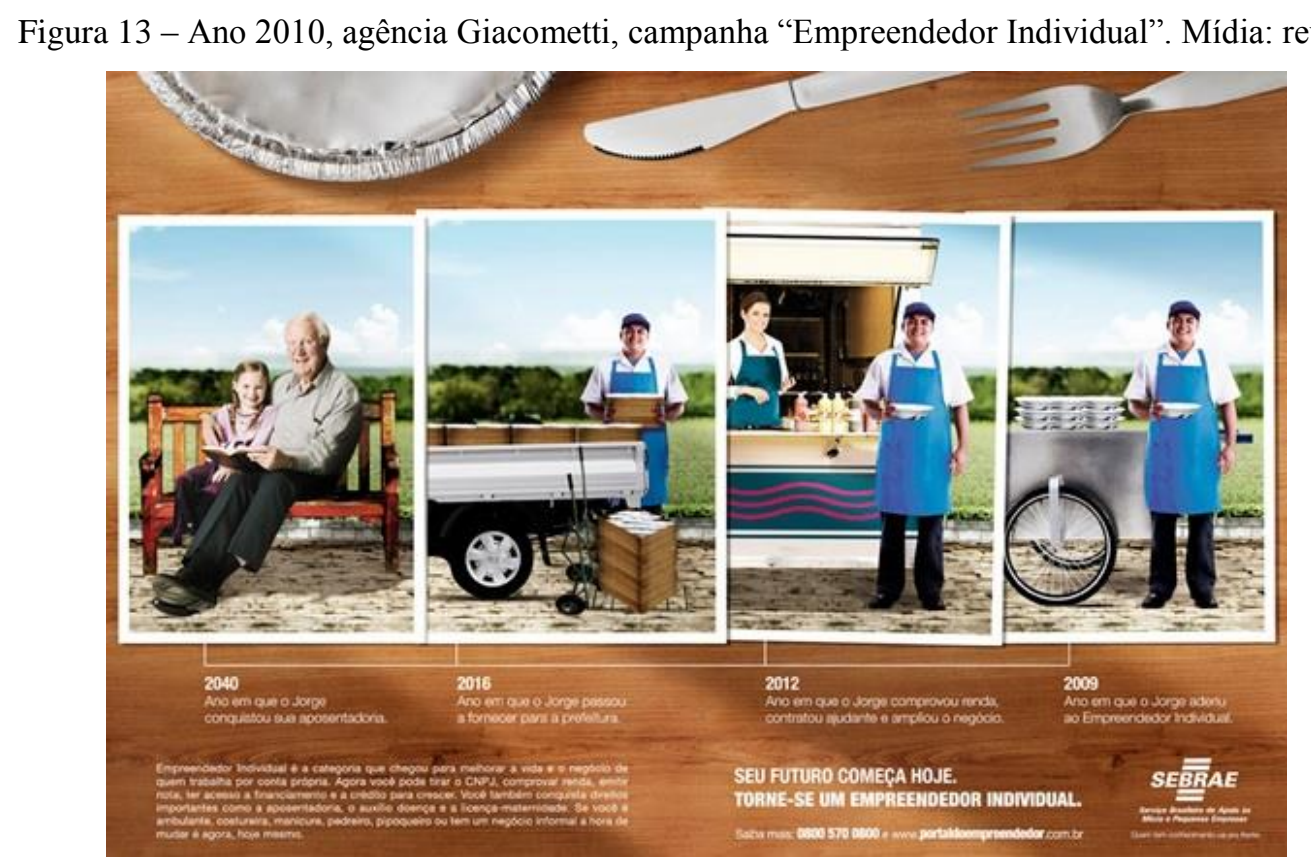

Fonte: material fornecido pela agência Giacometti

A primeira delas corresponde à figura 13 e é um anúncio de página dupla em revista. $\mathrm{O}$ anúncio apresenta a imagem de uma superfície de madeira sobre a qual estão expostas 4 fotografias, uma ao lado da outra. Na parte superior do leiaute há uma marmita de alumínio, 
um garfo e uma faca, elementos que permitem identificar o fundo do anúncio como uma mesa. As fotografias expostas constroem uma linha do tempo.

A primeira foto, da esquerda para a direita, mostra um senhor sentado em um banco de praça acompanhado por uma menina. Ele lê para ela e a imagem remete à cena de um avô com sua neta. A legenda diz: "2040 - Ano em que o Jorge conquistou sua aposentadoria”. A segunda foto mostra parte de uma camionete carregada com caixas de marmita. Ao lado do carro, há um carrinho de mão para cargas, também com caixas de marmitas. Em pé, sorrindo, há um homem uniformizado com chapéu e avental, segurando também uma caixa com marmitas. Ele sorri para a câmera. A legenda esclarece: "2016 - Ano em que o Jorge passou a fornecer para a prefeitura". A terceira foto, por sua vez, mostra o mesmo modelo da foto anterior, com o mesmo uniforme, sorrindo e olhando para a câmera enquanto tem nas mãos uma marmita. Ele está ao lado de um quiosque onde são vendidos os produtos. Dentro do quiosque há uma mulher, também uniformizada, que olha para a câmera e sorri. A legenda informa: "2012 - Ano em que o Jorge comprovou renda, contratou ajudante e ampliou o negócio”. A última imagem, à direita do leiaute, mostra o mesmo modelo das duas fotos anteriores, uniformizado e carregando uma marmita, ao lado de um carrinho de rua carregado, também, com marmitas. A legenda da foto é: “2009 - Ano em que o Jorge aderiu ao Empreendedor Individual”.

A parte inferior do anúncio traz um texto explicativo sobre a formalização, o título da peça, o telefone da central de relacionamento do Sebrae, o endereço da entidade na internet e a assinatura publicitária, no canto inferior direito. O texto diz: "Empreendedor Individual é a categoria que chegou para melhorar a vida e o negócio de quem trabalha por conta própria. Agora você pode tirar o CNPJ, comprovar renda, emitir nota, ter acesso a financiamento e a crédito para crescer. Você conquista também direitos importantes como a aposentadoria, o auxílio doença e a licença maternidade. Se você é ambulante, costureira, manicure, pedreiro, pipoqueiro ou tem um negócio informal, a hora de mudar é agora, hoje mesmo”. O título, logo ao lado, afirma: "Seu futuro começa hoje. Torne-se um empreendedor individual”.

A mensagem publicitária é instrumental, construída por argumentos racionais apresentados de duas maneiras na peça: a primeira, pela sequência de imagens e suas legendas. A segunda, pelo texto do anúncio. Porém, a mensagem apresenta também características relacionais, uma vez que o anúncio traz conceitos como família e envelhecimento. A ideia é que o receptor veja a si mesmo nas imagens e opte pela formalização de seu negócio para, no futuro, desfrutar de uma aposentadoria tranquila ao lado de sua família. As imagens são, também como na primeira análise, explicativas. Aliadas às legendas, contam a história de Jorge 
e dão ênfase a alguns dos benefícios da formalização ao longo de sua vida, tanto em aspectos profissionais quanto pessoais.

A função da linguagem que predomina no anúncio analisado é a conativa, refletida no texto, uma vez que são utilizados o imperativo e o vocativo na $2^{\text {a }}$ pessoa do tempo verbal. Expressões como "Agora você...", "Você também conquista", "Seu futuro..." e "Torne-se..." são exemplos da função conativa da linguagem. As imagens refletem a função conativa ao apresentarem, na sequência, a evolução da empresa após a formalização e o benefício da aposentadoria: a quantidade de marmitas aumentando a cada cena, o carrinho se transformando em quiosque, o transporte do produto em veículo motorizado e, por fim, Jorge e sua neta.

Também é possível identificar a função referencial, em especial nas legendas das fotos, uma vez que contam a história da vida e da empresa de Jorge. Além disso, a função fática e a poética se fazem presentes. A primeira, pela redundância de imagens e textos. Como exemplo, pode ser observada a repetição do modelo em três das fotos apresentadas, o que busca criar e manter a comunicação entre emissor e receptor. A segunda, pela ênfase na forma da mensagem: uma linha do tempo criada tanto pelo texto, quanto pela apresentação das imagens: O leiaute também demonstra, pela organização de seus elementos, a passagem do tempo.

Analisando as imagens sob o ponto de vista das representações sociais, é possível afirmar que a ancoragem do conceito é revelada na utilização de expressões como "categoria que chegou para melhorar a vida e o negócio de quem trabalha por conta própria" e "Se você é ambulante, costureira, manicure, pedreiro, pipoqueiro ou tem um negócio informal”. A partir dessa classificação, a estratégia de comunicação para objetivar o conceito não foi tentar apresentá-lo em toda a sua amplitude, mas sim direcioná-lo a uma das categoriais permitidas pela legislação. No caso, o vendedor de marmitas, vestindo chapéu e avental. Assim como nas outras análises já realizadas, percebe-se que elementos como o uniforme e a própria imagem das marmitas não são suficientes para identificar o modelo como microempreendedor individual. Isso acontece pela interação entre a imagem e o texto do anúncio, particularmente pelas legendas das fotos, evidenciando mais uma vez a complementaridade entre esses elementos. É muito importante que a apresentação do conceito fique clara para o receptor da mensagem, uma vez que esse conceito é o estímulo que poderá dar início ao processo de identificação e levar o destinatário da mensagem a modificar seu comportamento. Neste caso, o comportamento desejado pelo emissor é a formalização do negócio. 
Figura 14 - Ano 2010, agência Giacometti, campanha “Empreendedor Individual”. Mídia: filme
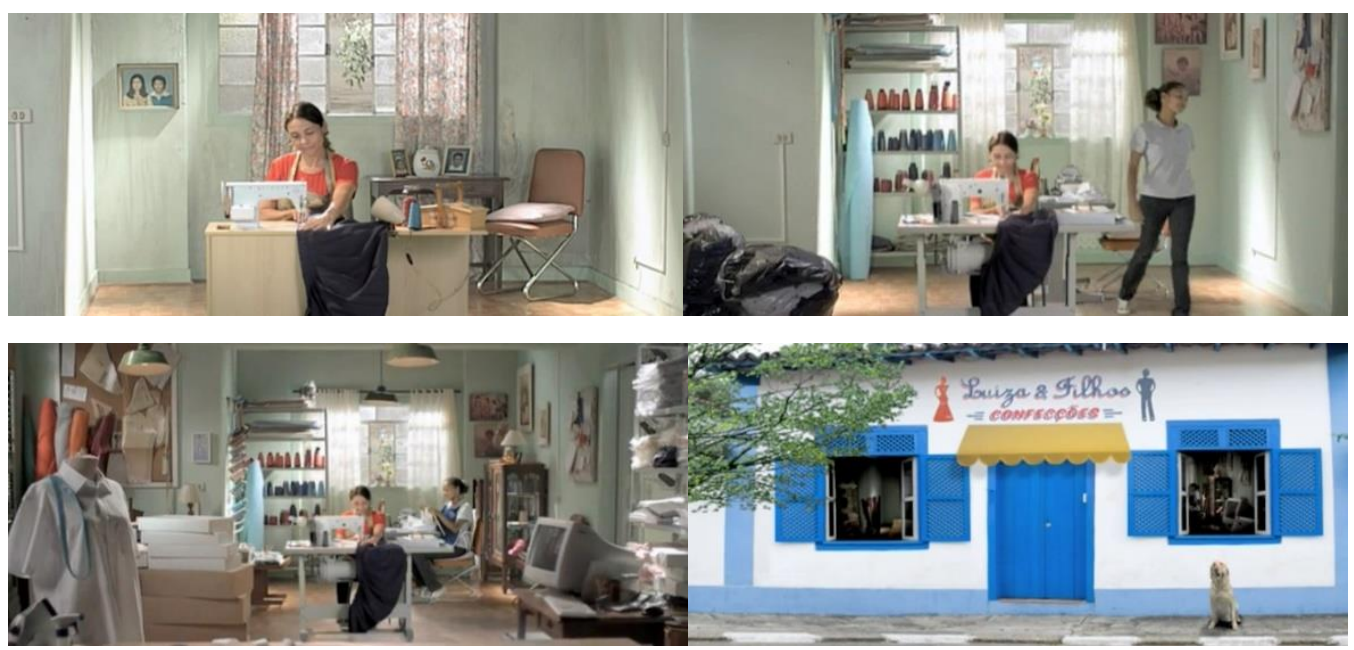

Fonte: material fornecido pela agência Giacometti

O filme da campanha, com duração de 30 segundos para a TV aberta (figura 14), também buscou trabalhar com a questão cronológica. Inicialmente é apresentada a imagem em plano fechado de uma costureira em seu ateliê, trabalhando sozinha. Ao longo do filme a câmera abre gradualmente e o cenário se modifica conforme a locução: "A Luiza trabalhava por conta própria, no seu quartinho. Aí, virou empreendedora individual e começou a crescer. Contratou uma ajudante, tirou CNPJ, e cresceu mais um pouquinho. Passou a fornecer uniformes com nota fiscal, e cresceu mais. Luiza também conquistou o direito à aposentadoria. Um dia ela vai parar, mas o seu negócio vai continuar crescendo. Torne-se um empreendedor individual e comece o seu futuro hoje. Sebrae".

Luiza é apresentada como uma mulher madura, com cerca de 40 anos. Veste avental e blusa vermelha e seus cabelos estão presos. Sua ajudante é uma mulher negra, com idade aproximada de 20 anos, que veste calça jeans e blusa cinza. A fachada do ateliê de Luiza é mostrada ao fim do filme e o negócio funciona na própria casa da costureira. O letreiro diz, em letras cursivas, "Luiza \& Filhos Confecções". Há o desenho de um homem e de uma mulher, cada um de um lado da fachada, acima de um toldo amarelo. As janelas e porta da casa são pintadas de azul, e há um cachorro na calçada em frente ao ateliê.

Mais uma vez pode-se dizer que a mensagem é instrumental, pois a necessidade da formalização é explicitada como condição para adquirir os direitos mencionados. Já a imagem de Luiza é explicativa, pois busca demonstrar sua condição de informal e, posteriormente, de microempreendedora individual. A principal função da linguagem presente no filme publicitário é a conativa, já que o objetivo da peça é estimular a formalização dos empreendedores informais com frases como "Torne-se um empreendedor individual e comece 
o seu futuro hoje". No entanto, o filme apresenta também a função referencial ao narrar a história de vida de Luiza e o crescimento de seu negócio. A maneira como a história é apresentada, ou seja, como Luiza, mulher trabalhadora, consegue crescer com a formalização, sustentar sua família e dar continuidade a seu empreendimento mesmo após a sua aposentadoria caracteriza também a função poética da linguagem.

Com relação à representação social, é possível identificar a ancoragem do conceito no termo "trabalhava por conta própria". A objetivação acontece por meio da imagem de Luiza: mulher com cerca de 40 anos, vestindo avental e trabalhando em sua máquina de costura. Mesmo assim, a complementaridade entre texto (locução) e imagem ainda se faz necessária para comunicar de forma completa o conceito de MEI. Não se pode afirmar, apenas pela imagem de Luiza costurando, que ela é uma microempreendedora individual. É preciso que a narração do filme conte sua história de formalização e conquista de direitos.

A narrativa associa claramente a formalização do negócio de Luiza a seu crescimento e sucesso profissional, e esses são os elementos que buscam iniciar o processo de verificação de identidade no receptor da mensagem. Assim, o microempreendedor individual impactado pela comunicação visualiza o futuro do seu negócio e, idealmente, aumenta sua autoestima como empresário, reforçando o aspecto positivo de empreender formalmente. O trabalhador informal, por outro lado, é apresentado a uma lista de benefícios pessoais e empresariais aos quais não tem direito. A intenção do Sebrae é gerar nesse empreendedor a necessidade de cidadania empresarial, conseguida por meio da formalização de seu negócio, objetivo final da comunicação publicitária. 
Figura 15 - Ano 2010, agência Giacometti, campanha "Empreendedor Individual”. Mídia: merchandising televisivo
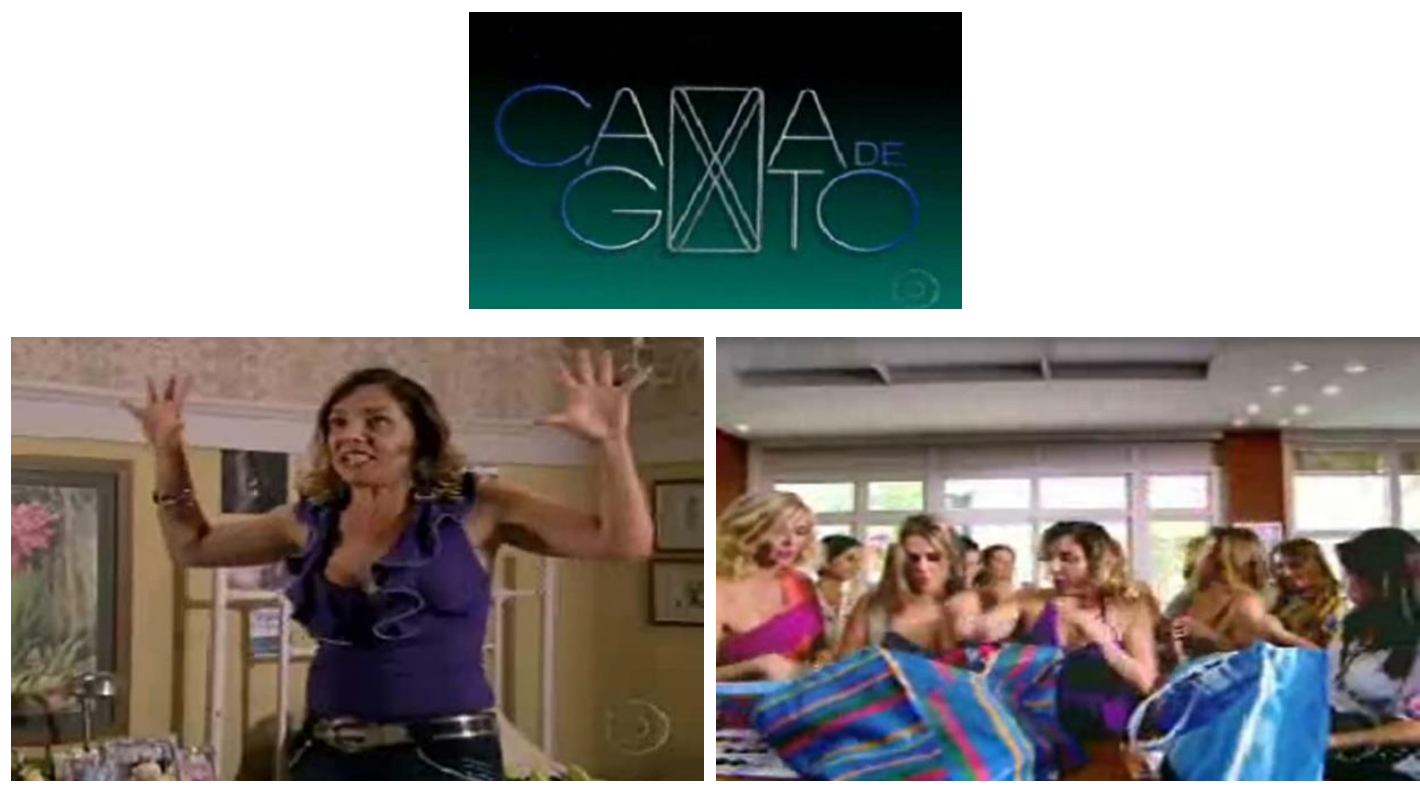

Fonte: material fornecido pela agência Giacometti

A campanha criada para o Empreendedor Individual em 2010 teve, ainda, duas ações de merchandising na novela Cama de Gato, veiculada pela Rede Globo de Televisão, no horário das 18h (figura 15). A personagem Taís, representada pela atriz Heloísa Perissé, sonha em ter uma loja de roupas e começa a trabalhar como sacoleira. Ela vê o negócio crescer, mas tem dificuldade para comprar mercadoria, vender para pessoas jurídicas e emitir nota fiscal. Após procurar o Sebrae, Taís se torna microempreendedora individual e conquista, assim, todos os direitos da categoria. Há dois momentos em que o Sebrae é citado durante a trama. Porém, a característica empreendedora da personagem acompanha o desenrolar da história, mesmo em momentos onde não há merchandising explícito.

Pode-se afirmar que a mensagem é instrumental, já que as vantagens da formalização são comunicadas de forma clara por meio do dia a dia da personagem, e que sua imagem é explicativa, pois ela representa o MEI. Além disso, a principal função da linguagem presente nas ações de merchandising é a referencial, já que o foco da comunicação é mostrar ao telespectador os benefícios da formalização, sem, no entanto, convidá-lo a formalizar seu negócio de maneira explícita. A função conativa aparece, portanto, como função da linguagem secundária no merchandising. É importante destacar que a sutileza da comunicação, neste caso, não enfraquece o processo persuasivo. Ao contrário, pode até mesmo torná-lo mais eficaz, uma vez que o público é impactado em um momento de lazer, onde, a princípio, não há resistência à comunicação publicitária. 
A representação social do microempreendedor individual na novela se dá por meio da ancoragem em termos como "empresária da moda", "dona de firma" e "empreendedora", e por meio da objetivação na própria caracterização da personagem: mulher loira com cerca de 30 anos. A partir de então, a identificação do público com Taís é construída ao longo da trama e a narrativa trabalha para que esse processo seja o da comparação social ascendente, conforme descrito por Tajfel. Ou seja, o público deve ver em Taís a possibilidade de melhorar de vida, de ser como ela, deve admirá-la. Em outras palavras, o Sebrae mostra ao telespectador que, assim como a personagem, ele tem um sonho de empreender, é trabalhador, sustenta os filhos e a casa (Taís é mãe solteira) e pode ter sucesso com seu negócio, principalmente se buscar a formalização.

\subsubsection{Ei. Tá na hora de se formalizar - Lew'LaralTBWA 2010}

Criada pela agência Lew’LaralTBWA, em 2010, a campanha "Ei. Tá na hora de se formalizar" foi a maior divulgação já realizada pelo Sebrae para o microempreendedor individual, no que concerne a quantidade e variedade de peças publicitárias produzidas. É possível que essa tenha sido a maior divulgação já realizada também em termos de investimento, porém essa informação não foi tornada pública para a investigação. O objetivo de campanha continuou sendo a formalização. Foram selecionadas para análise cinco peças que apresentam imagens representativas desse público-alvo. 
Figura 16 - Ano 2010, agência Lew’Lara\TBWA, campanha “Ei. Tá na hora de se formalizar”. Mídia: revista

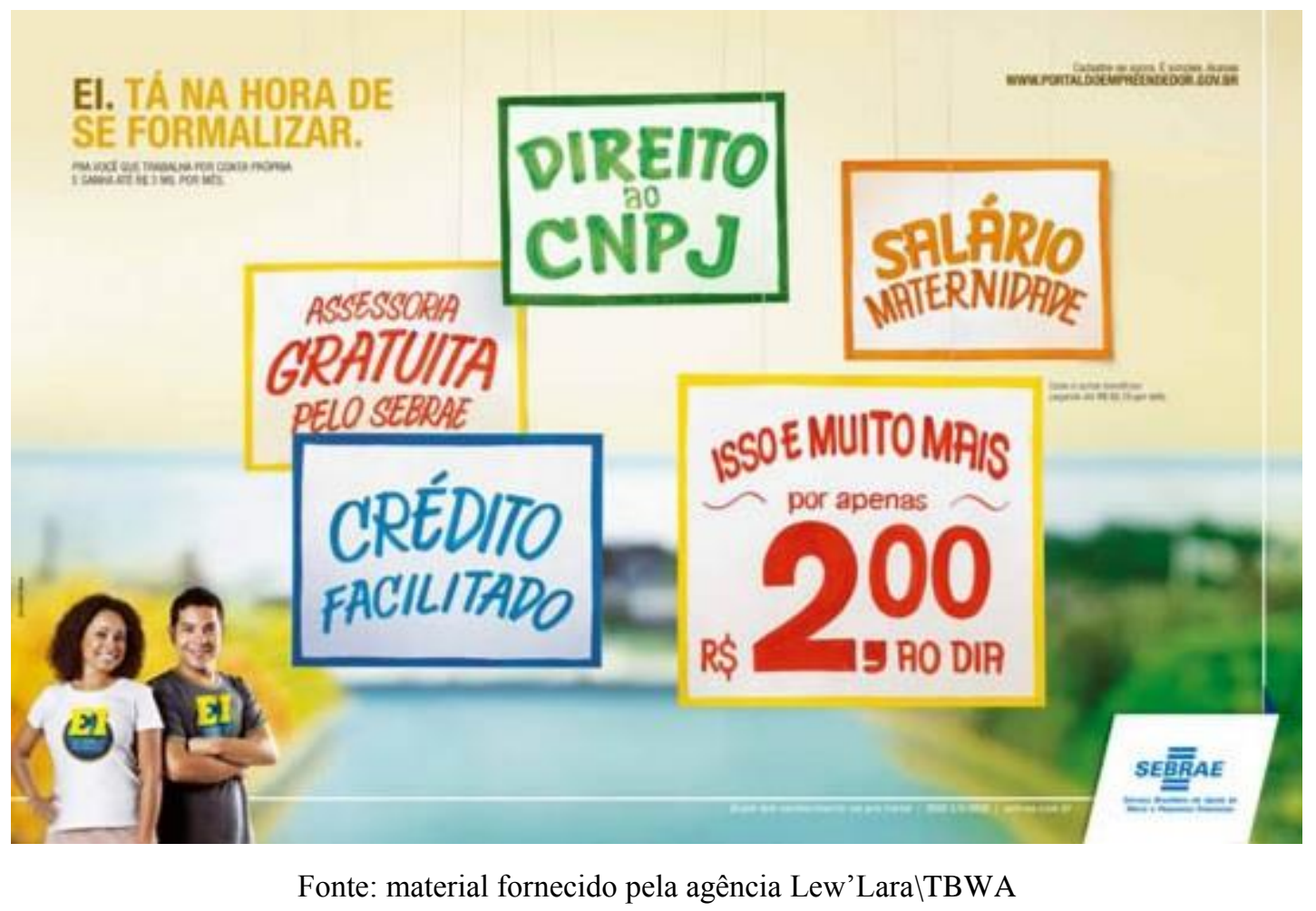

A primeira delas (figura 16) é um anúncio de página dupla em revista, que mostra duas pessoas lado a lado, um homem e uma mulher, olhando para a câmera. A mulher, à esquerda, posiciona-se com uma das mãos na cintura. O homem, por sua vez, tem os braços cruzados. Ambos sorriem. Na camiseta de cada um, uma mensagem: "EI. Sou dono do meu negócio". O corte da imagem não permite a visualização das pernas do casal. A dupla está posicionada no lado esquerdo inferior do anúncio e faz contraponto com os outros elementos em cena. Como fundo, percebe-se, de maneira desfocada, uma paisagem. Em primeiro plano, preenchendo toda a parte central do anúncio, há cinco cartazes com as seguintes informações (em sentido horário): crédito facilitado, assessoria gratuita pelo Sebrae, direito ao CNPJ, salário maternidade, isso e muito mais por apenas $\mathrm{R} \$ 2,00$ ao dia. O último cartaz, em particular, é acompanhado por um texto explicativo, à direita da imagem, que diz: "Este e outros benefícios pagando até R\$62,10 por mês".

O título do anúncio, à esquerda da peça, afirma: "Ei. Tá na hora de se formalizar". O subtítulo, logo abaixo, "Para você que trabalha por conta própria e ganha até R \$3 mil por mês". No canto oposto do leiaute, o texto "Cadastre-se agora. É simples. Acesse www.portaldoempreendedor.gov.br" direciona a ação do receptor. A assinatura da peça é acompanhada pelo slogan "Quem tem conhecimento vai pra frente", o telefone da central de relacionamento do Sebrae e o portal da entidade na internet. 
O anúncio não apresenta qualquer indicação sobre as atividades profissionais desenvolvidas pelos modelos. Além da frase "EI. Sou dono do meu negócio" na camiseta de ambos, não há nenhum elemento que os caracterize como microempreendedores individuais. Em uma possível referência à classe $\mathrm{C}$, os cartazes fazem alusão à comunicação de varejo, pois se assemelham aos que apresentam ofertas do dia em supermercados, caracterizando como popular o grupo ao qual pertence o microempreendedor individual.

A mensagem da peça analisada é predominantemente instrumental, pois argumenta racionalmente sobre os benefícios da formalização. Assim como nas peças analisadas anteriormente, a imagem dos microempreendedores individuais também é explicativa. Isso porque é preciso evidenciar ao receptor que os dois indivíduos retratados ali são MEI e têm direito aos benefícios listados, o que ocorre principalmente pela frase estampada em suas camisetas.

A função conativa é claramente a função da linguagem predominante no anúncio: procura persuadir o receptor e, para isso, é centrada no destinatário da mensagem, utiliza o imperativo e tem como vocativo a $2^{\mathrm{a}}$ pessoa verbal. Além disso, as imagens dos cartazes que remetem ao varejo permitem associá-las também à função conativa. Outras funções da linguagem identificadas na peça são a função referencial, já que os benefícios da formalização são elencados claramente no leiaute; a função fática, que evidencia o canal da comunicação pela redundância e está representada na sigla EI, que aparece três vezes no anúncio; e, por fim, a função poética, pois a preocupação com a forma de apresentar a mensagem é evidenciada na disposição dos cartazes.

Sob o ponto de vista das representações sociais é possível afirmar que a ancoragem, classificação do conceito de microempreendedor individual, pode ser identificada pelas expressões "trabalha por conta própria" e "ganha até R \$ 3 mil por mês", e pela frase na camiseta dos modelos, "EI. Sou dono do meu negócio", que remetem à ideia de empresário. A concretização desse conceito, ou seja, a objetivação, é caracterizada pela imagem do casal: mulher negra, vestida com blusa branca onde se vê a frase "EI. Sou dono do meu negócio", mãos na cintura e sorriso no rosto. O homem também sorri, tem os braços cruzados e veste camiseta de cor escura onde está estampada a mesma frase. Essa imagem, por si só, não garante a objetivação do conceito, tornando-o dependente do texto. Mais uma vez, percebe-se a importância da interação entre texto e imagem para a clareza da mensagem transmitida.

$\mathrm{O}$ anúncio analisado é fortemente marcado pela complementaridade entre imagem e texto, uma vez que o conceito de MEI é de difícil objetivação. Assim, o receptor da mensagem compreende que os modelos representam microempreendedores individuais somente ao ler o 
título do anúncio ou a mensagem estampada em suas camisetas. É curioso notar, ainda, que o termo "empreendedor individual” não é utilizado na peça, apenas sua sigla, EI, que se confunde com a interjeição de chamamento. Somente a classificação do conceito de MEI, ou seja, “empresário que trabalha por conta própria e ganha até 3 mil reais por mês" é explicitada no anúncio.

Nesse contexto, o processo de identificação buscado pela publicidade é desencadeado pela exposição do receptor ao anúncio e, consequentemente, à imagem do microempreendedor individual. Esse estímulo é, então, avaliado e comparado à identidade padrão do público. Nesse caso, a identidade que se quer atingir é aquela que remete ao perfil empreendedor do receptor da mensagem. Caso ele já seja um MEI, a mensagem pode contribuir para aumentar sua autoestima. Caso ele tenha perfil para se tornar MEI, mas ainda trabalhe na informalidade, a identidade padrão não é verificada. Como consequência, há dissonância e o receptor da mensagem pode ser estimulado a mudar seu comportamento para eliminá-la. Dessa forma, o comportamento esperado pelo Sebrae é a formalização.

Figura 17 - Ano 2010, agência Lew’Lara|TBWA, campanha “Ei. Tá na hora de se formalizar”. Mídia: folder
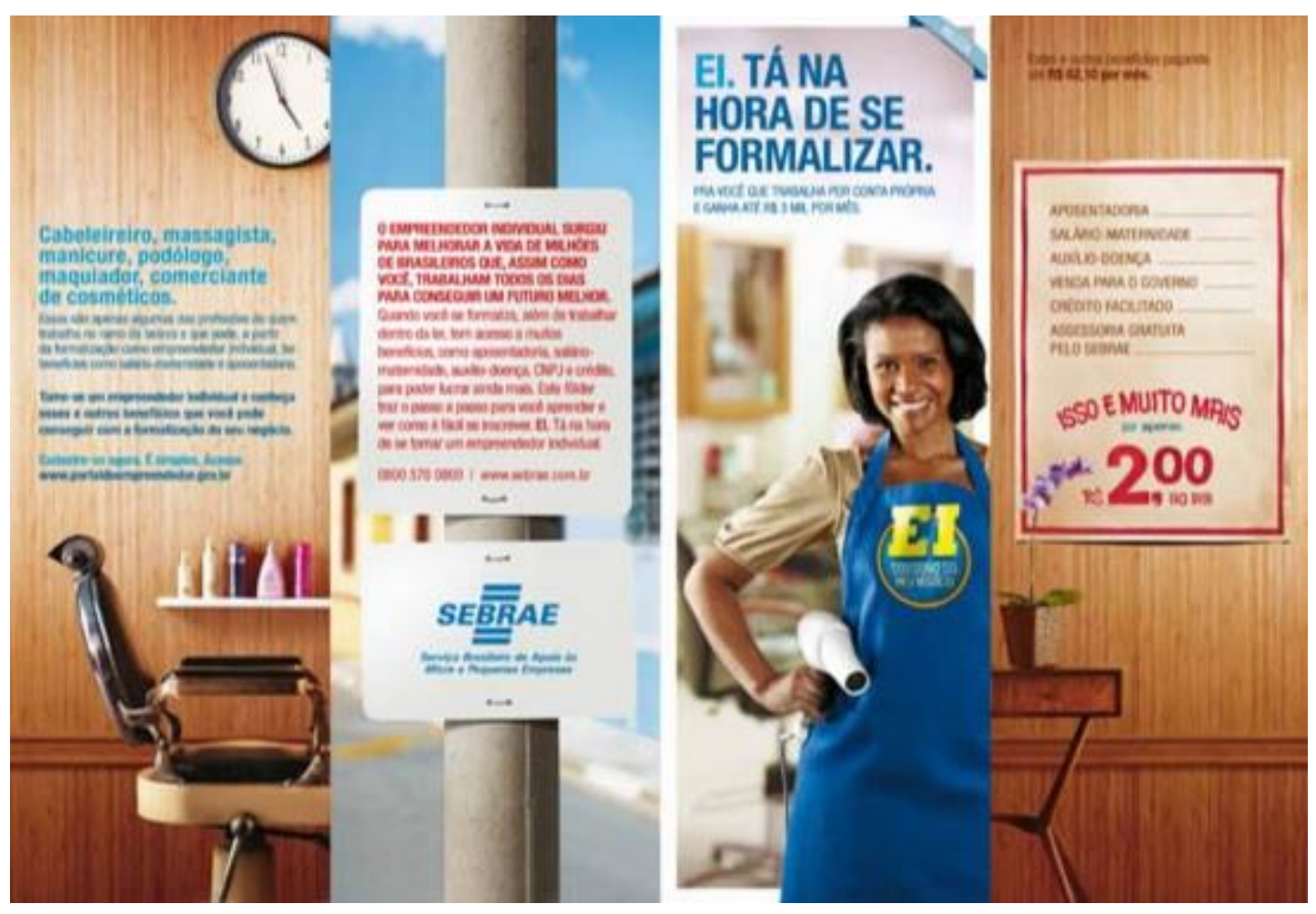

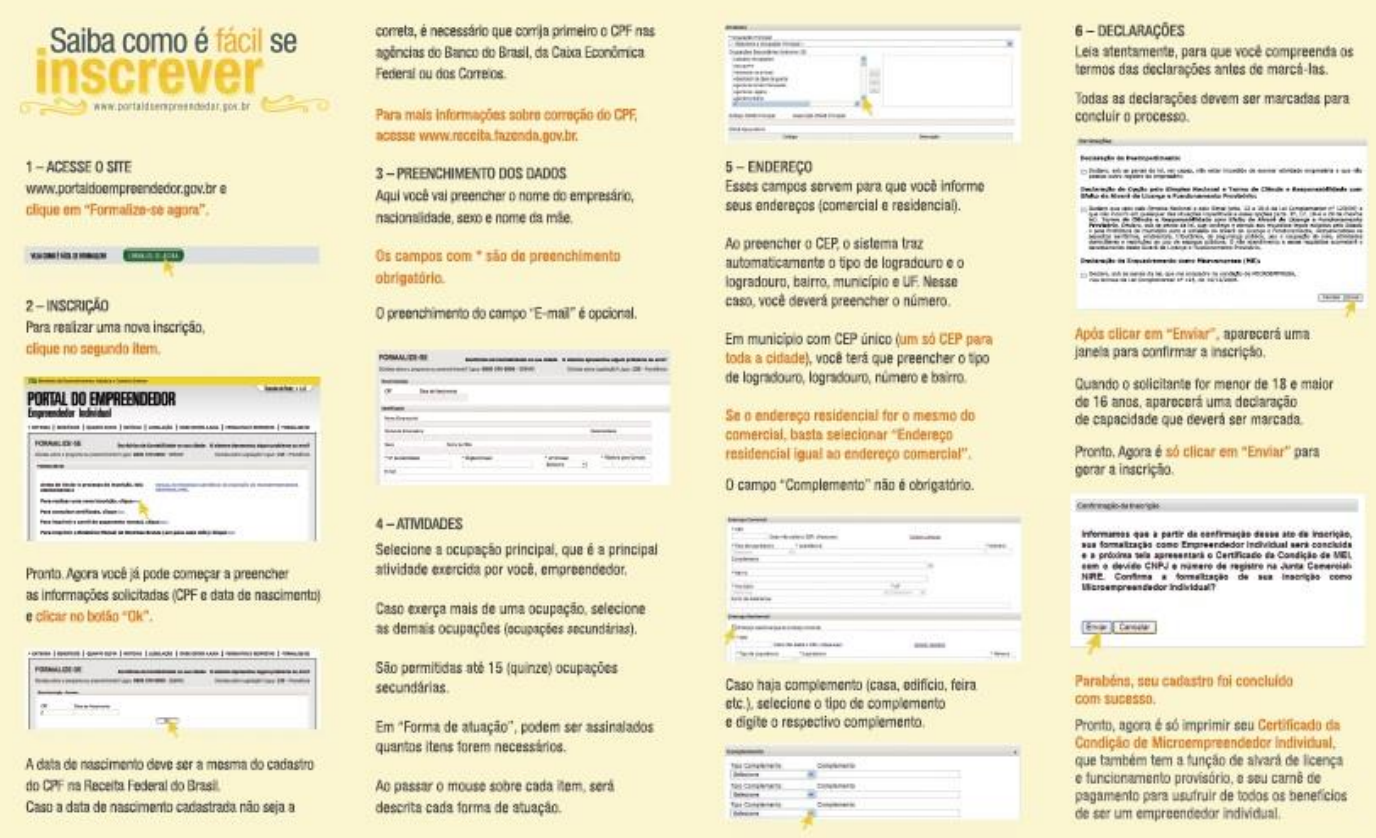

Fonte: material fornecido pela agência Lew'LaralTBWA

Outra peça da campanha que utiliza a imagem do microempreendedor individual é um folder (figura 17) direcionado ao empreendedor informal que atua na área de beleza (cabeleireiros, manicures, coloristas etc.). A capa do material apresenta a imagem de uma mulher negra, vestindo avental azul e carregando um secador de cabelos nas mãos. $\mathrm{O}$ avental possui a frase "EI. Sou dono do meu negócio". Ao fundo, percebe-se que ela está em um salão de beleza. O título do folder traz a mensagem "Ei. Tá na hora de se formalizar"; e o subtítulo, a frase "Pra você que trabalha por conta própria e ganha até R\$ 3 mil por mês".

Outras páginas do folder mostram mais elementos que fazem referência ao ambiente de salão de beleza, como uma cadeira de barbeiro próxima a um local onde há xampus e outros produtos, e um cartaz afixado em uma parede onde há um aparador com um vaso de flores. A primeira cena é acompanhada pelo texto "Cabeleireiro, massagista, manicure, podólogo, maquiador, comerciante de cosméticos. Essas são apenas algumas das profissões de quem trabalha no ramo da beleza e pode, a partir da formalização como empreendedor individual, ter benefícios como salário-maternidade e aposentadoria. Torne-se um empreendedor individual e conheça esses e outros benefícios que você pode conseguir com a formalização do seu negócio. Cadastra-se agora. É simples. Acesse www.portaldoempreendedor.gov.br”. Já a segunda cena apresenta, no próprio cartaz retratado, a seguinte lista: “Aposentadoria / Salário-maternidade / Auxílio-doença / Venda para o governo / Crédito facilitado / Assessoria gratuita pelo Sebrae / 
Isso e muito mais por apenas $\mathrm{R} \$ 2,00$ ao dia”. No alto da página, uma nota apresenta o cálculo: "Estes e outros benefícios pagando até R \$ 62,10 por mês".

A contracapa do folder mostra a imagem de um poste onde estão afixados dois cartazes. O primeiro traz informações sobre o MEI, o telefone da central de relacionamento e o endereço do portal do Sebrae na internet: "O empreendedor individual surgiu para melhorar a vida de milhões de brasileiros que, assim como você, trabalham todos os dias para conseguir um futuro melhor. Quando você se formaliza, além de trabalhar dentro da lei, tem acesso a muitos benefícios, como aposentadoria, salário-maternidade, auxílio-doença, CNPJ e crédito, para poder lucrar ainda mais. Este folder traz o passo a passo para você aprender e ver como é fácil de inscrever. EI. Tá na hora de se tornar um empreendedor individual”. Já o segundo cartaz traz a assinatura da peça, ou seja, a marca do Sebrae. O interior do folder apresenta o passo a passo mencionado.

Assim como acontece em outras análises, é identificada uma mensagem instrumental na peça, visto que os benefícios da formalização, bem como um passo a passo para realizá-la, são apresentados no folder. A imagem da cabeleireira é explicativa, na medida em que procura ilustrar o conceito de microempreendedor individual. Porém, isso é conseguido somente com auxílio do texto, tanto do título do folder, como da mensagem estampada no avental vestido por ela. É interessante notar que, em mais uma análise, a complementaridade entre texto e imagem se mostra evidente, mesmo quando o emissor da mensagem dá ênfase a uma das categorias permitidas para o MEI e utiliza elementos que remetem diretamente ao tipo de negócio escolhido (nesta peça, o serviço de cabeleireiro). A representação social é construída, assim, pela ancoragem, evidenciada no uso de expressões como "profissão", "trabalha por conta própria", "ganha até R \$ 3 mil por mês", "EI. Sou dono do meu negócio" e pela enumeração de algumas atividades permitidas pela legislação, como "cabeleireiro, massagista, manicure, podólogo, maquiador, comerciante de cosméticos", e também pela objetivação, presente na imagem da mulher negra, com cerca de 30 anos, uniformizada e com o secador de cabelos nas mãos.

É relevante destacar a participação do texto na construção do conceito de MEI, uma vez que as imagens, por si sós, novamente, não conseguem apresentá-lo de forma completa. Ao utilizar elementos como o secador de cabelos e o avental, é possível transmitir a mensagem de que a modelo trabalha no setor de serviços com foco em beleza. Porém, o conceito de microempreendedor individual é mais amplo, uma vez que ela é dona do seu negócio. Essa mensagem específica não consegue ser transmitida apenas pela imagem. O texto se mostra necessário, então, para completar a comunicação tal qual deseja o emissor da mensagem. A 
identidade padrão acionada no processo de identificação deve ser aquela correspondente à de empresário, dono de negócio. Por isso, comunicar apenas a atividade "cabeleireira" não atende aos objetivos da comunicação. A complementaridade entre texto e imagem apresenta-se como estratégia fundamental para a disseminação do conceito de microempreendedor individual. Sob a perspectiva das representações sociais, nota-se a dificuldade da imagem para objetivar o termo e, assim, transmitir a mensagem desejada.

Por fim, predomina no folder a função conativa da linguagem. Percebe-se o uso recorrente do verbo no imperativo e do vocativo em $2^{a}$ pessoa. A postura da empresária, olhando diretamente para o receptor e evidenciando a mensagem em seu avental, também denota a função conativa na peça. A função fática se apresenta pelo trocadilho com a sigla EI e por sua repetição, assim como a função referencial está presente nas informações sobre a formalização, apresentadas de maneira racional, clara e assertiva.

Figura 18 - Ano 2010, agência Lew’Lara\TBWA, campanha “Ei. Tá na hora de se formalizar”. Mídia: revista

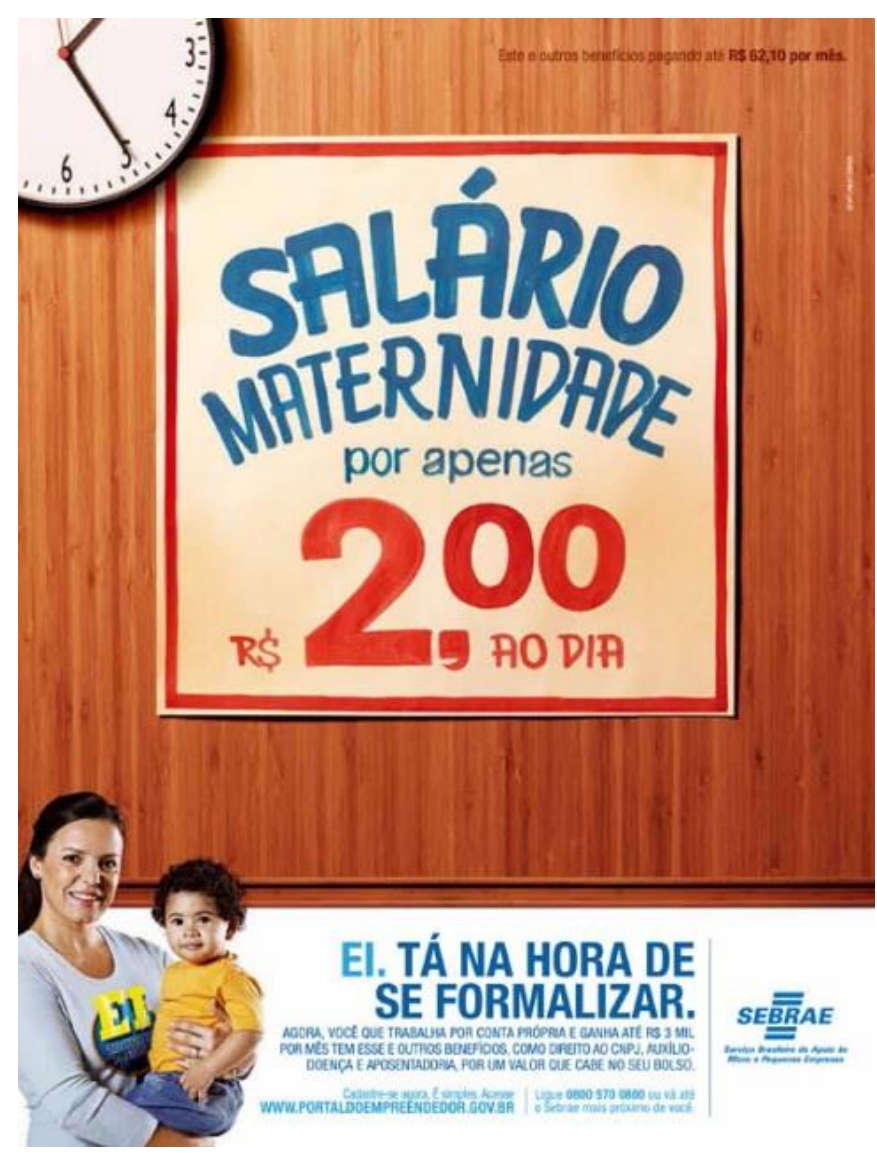

Fonte: material fornecido pela agência Lew'Lara\TBWA

A terceira peça publicitária analisada é um anúncio de revista, em formato página simples (figura 18). O anúncio traz a imagem de um cartaz, cujo leiaute faz alusão à 
comunicação de varejo e no qual está escrito "Salário maternidade por apenas R \$ 2,00 ao dia". No canto superior esquerdo há um relógio, o que permite identificar uma parede como fundo da imagem. Do outro lado, a frase: "Este e outros benefícios pagando até R\$ 62,10 por mês". Abaixo, à esquerda do leiaute, há uma mulher de meia idade com um bebê no colo. Ela sorri em direção ao receptor e sua camiseta carrega a frase "EI. Sou dono do meu negócio". O bebê veste camisa amarela e shorts azuis. Ao lado direito, o texto do anúncio e a marca do Sebrae: “Ei. Tá na hora de se formalizar. Agora, você que trabalha por conta própria e ganha até R\$3 mil por mês tem esse e outros benefícios, como direito ao CNPJ, auxílio-doença e aposentadoria por um valor que cabe no seu bolso. Cadastre-se agora. É simples. Acesse www.portaldoempreendedor.gov.br. Ligue 08005700800 ou vá até o Sebrae mais próximo de você".

A mensagem apresenta-se, novamente, como instrumental, uma vez que descreve racionalmente os benefícios da formalização, com ênfase no salário maternidade. A imagem do cartaz é explicativa, bem como a da modelo com o bebê. Ambas buscam passar informações sobre os direitos do MEI e sobre o que ele é. No entanto, e mais uma vez, a imagem da mãe necessita do auxílio do texto para comunicar de forma eficiente. Apenas quando é associada ao texto do anúncio e à frase estampada na camisa da modelo é possível compreender que ela representa uma microempreendedora individual. Além disso, o anúncio não apresenta qualquer elemento que permita ao receptor conhecer o ramo de negócios em que ela atua como empresária.

As funções da linguagem identificadas na peça são a conativa, a referencial e a fática. A primeira delas, característica da publicidade, é a predominante e se justifica pelo uso do imperativo e da $2^{\text {a }}$ pessoa verbal como vocativo, além de características apresentadas pela imagem: o cartaz é o principal elemento da peça e a MEI, bem como a criança, posam para a câmera olhando diretamente para o receptor. A função referencial, por sua vez, está presente nas informações assertivas acerca dos benefícios da formalização. A interjeição "ei”, que também funciona como trocadilho para a sigla referente a "empreendedor individual", repetese na peça, gerando redundância, o que permite maior clareza na comunicação e denota a função fática da linguagem. Todas essas funções já haviam sido identificadas em outras peças analisadas neste trabalho.

Nota-se, uma vez mais, a dificuldade em ancorar e objetivar o conceito de microempreendedor individual. Assim como nas outras peças da campanha, a ancoragem do termo acontece pelo uso de expressões como "EI. Sou dono do meu negócio", "trabalha por conta própria" e "ganha até R \$ 3 mil por mês". A objetivação do conceito na imagem da mulher 
com o bebê é a primeira objetivação explícita do MEI como mãe, e talvez seja justamente por isso que não consiga comunicar de forma eficaz o conceito sem o auxílio do texto. Não é possível saber, apenas pela imagem da modelo com o bebê, que ela é empreendedora e, muito menos, uma microempreendedora individual. Isso acontece somente ao associar a imagem com o texto do anúncio ou, ainda, com a frase estampada em sua blusa.

A partir dessa associação, o processo de identificação é direcionado para a identidade padrão desejada pelo emissor que, neste caso, é a de empresário. No entanto, a imagem da mulher com a criança é tão fortemente associada à representação social de mãe que a comunicação é dificultada, já que o receptor da mensagem deverá ter o seguinte raciocínio ao visualizar o anúncio: a modelo é empresária e teve seu direito ao salário maternidade garantido pois é microempreendedora individual e, assim, dispõe de diversos benefícios empresariais e previdenciários, sendo o salário maternidade um deles.

Figura 19 - Ano 2010, agência Lew'Lara\TBWA, campanha “Ei. Tá na hora de se formalizar”. Mídia: revista

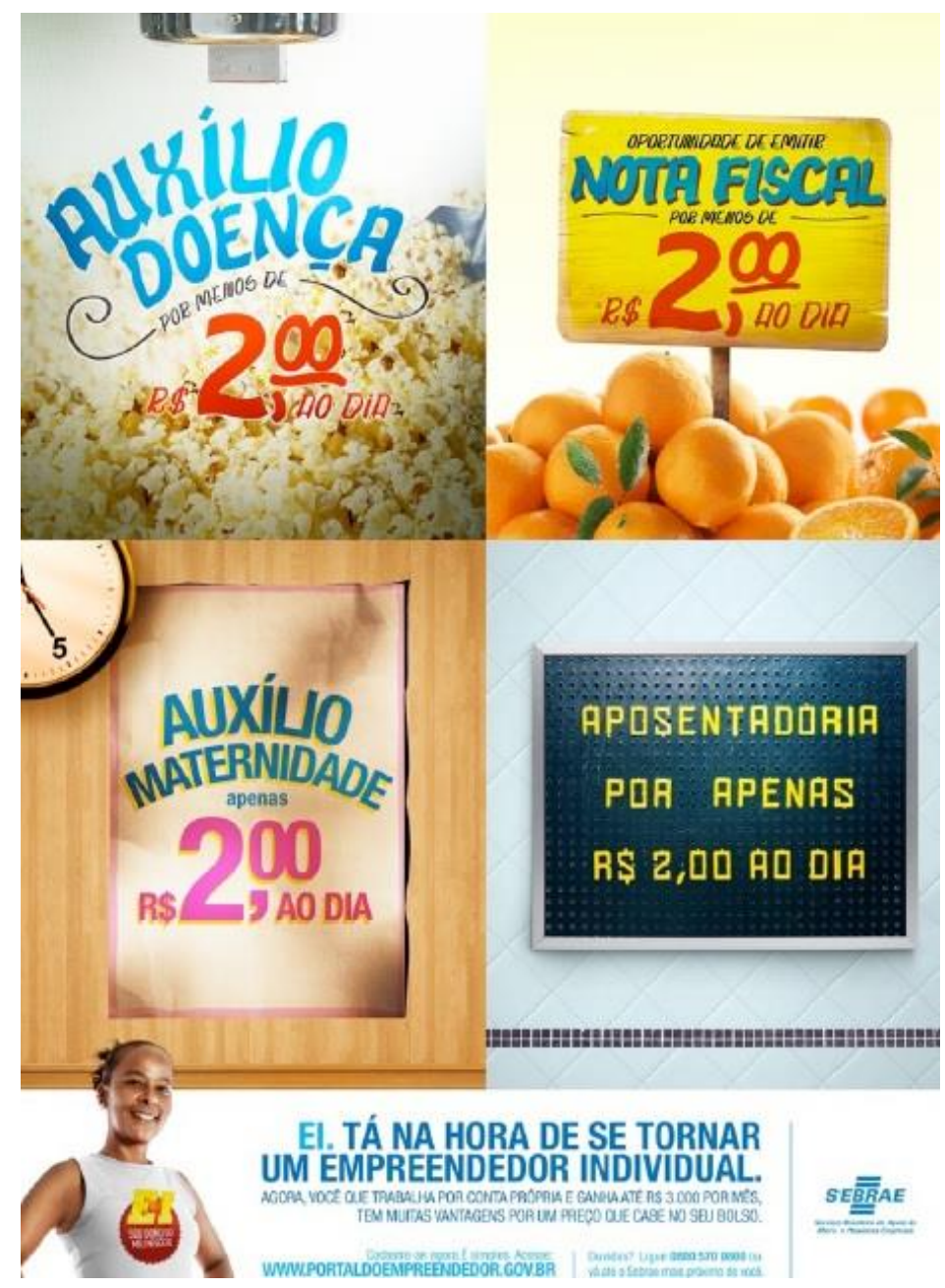

Fonte: material fornecido pela agência Lew’LaralTBWA 
Outra peça da campanha que traz uma imagem representativa do MEI é apresentada na figura 19. O leiaute de página simples para revista se divide em quatro grandes fotografias. Cada uma delas retrata um dos direitos de quem tem um negócio formalizado. A primeira imagem, no canto superior esquerdo da peça, mostra um carrinho de pipoca onde se lê, em seu vidro, "Auxílio doença por menos de $\mathrm{R} \$ 2,00$ ao dia". A imagem à direita mostra um ambiente de feira, com algumas laranjas e uma placa com os dizeres: "Oportunidade de emitir nota fiscal por menos de $\mathrm{R} \$ 2,00$ ao dia”. Abaixo e à esquerda, em uma parede com um relógio e um cartaz afixado, é possível ler: “Auxílio maternidade apenas R\$2,00 ao dia”. À direita, a imagem mostra um quadro de avisos pendurado em uma parede de azulejos onde se lê: "Aposentadoria por apenas $\mathrm{R}$ \$ 2,00 ao dia”. Logo abaixo das imagens, à esquerda, uma mulher negra, com cerca de 40 anos, posa com as mãos na cintura, olhando para a câmera e sorrindo. Ela veste uma camiseta branca onde a frase "EI. Sou dono do meu negócio" está estampada. Ao lado, o texto do anúncio: "Ei. Tá na hora de se formalizar. Agora, você que trabalha por conta própria e ganha até R\$ 3 mil por mês tem esse e outros benefícios, como direito ao CNPJ, auxíliodoença e aposentadoria por um valor que cabe no seu bolso. Cadastre-se agora. É simples. Acesse www.portaldoempreendedor.gov.br. Dúvidas? Ligue 08005700800 ou vá até o Sebrae mais próximo de você”. A peça é assinada com a logomarca do Sebrae.

Novamente, a mensagem publicitária é classificada como instrumental, já que apresenta, de maneira objetiva, os benefícios adquiridos por meio da formalização. Além disso, as imagens das placas são diretivas, uma vez que são imagens que buscam influenciar o receptor de forma objetiva, pois são imagens de pontos de venda. A imagem da microempreendedora individual, por sua vez, é classificada como explicativa, pois busca identificá-la como MEI para o público receptor da peça publicitária.

As funções da linguagem identificadas são as mesmas presentes em outras peças da campanha, já que o texto dos anúncios é praticamente o mesmo e os elementos gráficos estão alinhados para dar unidade à mensagem transmitida. Sendo assim, a principal função presente no anúncio é a conativa e pode ser identificada em expressões como "Tá na hora de se tornar um empreendedor individual”, "Agora, você que trabalha...", "Acesse”, "Ligue”, entre outras. As funções referencial e fática também estão presentes. A primeira, com foco no conteúdo da mensagem, em especial aquele apresentado nas placas, incluindo a imagem das mesmas. Já a função fática é identificada pela redundância de dois elementos: a sigla EI, que aparece no anúncio em dois momentos, e o valor de $\mathrm{R} \$ 2,00$, que aparece quatro vezes no leiaute. A redundância é um recurso utilizado pelo emissor na tentativa de manter o canal de comunicação aberto e, consequentemente, chamar atenção para o conteúdo da mensagem. 
Quanto à representação social do microempreendedor individual, ela também se repete, uma vez que a ancoragem do conceito se dá pelo emprego das expressões "EI. Sou dono do meu negócio", "trabalha por conta própria" e "ganha até R\$ 3 mil por mês", e a objetivação, pela imagem da mulher negra, de meia idade, vestindo camiseta com a frase da campanha. Consequentemente, a complementaridade entre imagem e texto é também evidente nesta peça de comunicação, já que o receptor da mensagem não consegue compreender que aquela mulher apresentada no anúncio é uma microempreendedora individual sem o auxílio do texto.

O processo de identificação é iniciado pela imagem da empresária e pela mensagem em sua blusa, destacando, novamente, a necessidade de interação entre texto e imagem. A identidade padrão que se busca ativar é justamente a de empresário, por meio da comparação social. Dessa forma, o Sebrae deseja que o público compreenda que é possível se formalizar e ter direito a benefícios previdenciários, assim como aconteceu com a empresária retratada na peça.

Para o microempreendedor individual, a identidade padrão será confirmada e seu comportamento como MEI legitimado. Para aqueles que trabalham na informalidade, a dissonância cognitiva gerada pela não identificação será o motivador da mudança de conduta, ou seja, da formalização. Em outras palavras, a comunicação contrasta, implicitamente, a categoria social do microempreendedor individual com a categoria social do informal, destacando as vantagens da primeira. Essa estratégia tem como objetivo promover a mudança da categoria social do informal: ao se formalizar, ele se desloca para a categoria social de MEI.

Figura 20 - Ano 2010, agência Lew’LaralTBWA, campanha “Ei. Tá na hora de se formalizar”. Mídia: folder

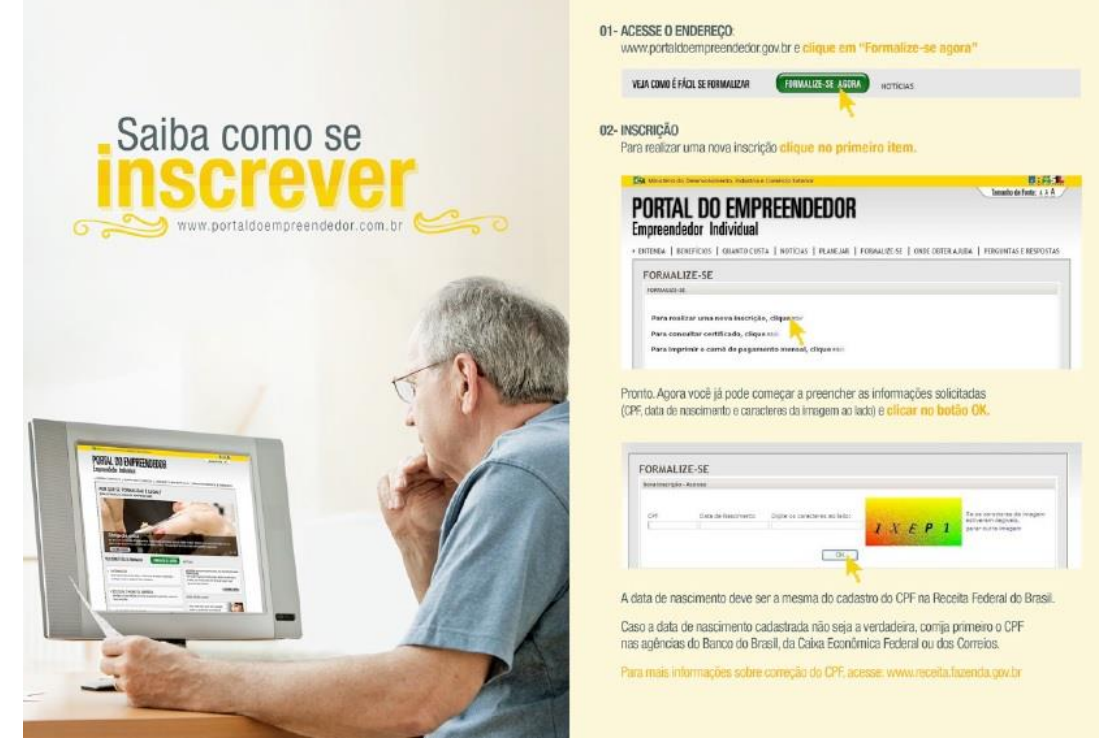

Fonte: material fornecido pela agência Lew’LaralTBWA 
A última peça da campanha a ser analisada é um folder (figura 20) que apresenta ao público o passo a passo para a formalização, realizada online. A capa do material traz a imagem de um senhor idoso, sentado em frente a um computador. Ele usa camiseta cinza e óculos, segura o folder em uma das mãos e apoia o queixo com a outra. Na tela do computador é possível ver o leiaute do Portal do Empreendedor, site do governo federal onde é feito o registro. O fundo da imagem é branco e desfocado, e o título afirma: "Saiba como se inscrever. www.portaldoempreendedor.gov.br". A parte interna do folder traz o passo a passo para a formalização, com imagens das telas que o empreendedor irá visualizar ao acessar o portal.

A mensagem do folder é classificada como instrumental, uma vez que se trata de um roteiro para a formalização. As imagens da peça são explicativas. Tanto a imagem do idoso, que busca demonstrar um empreendedor informal registrando-se como microempreendedor individual, quanto aquelas imagens das telas do site, que buscam facilitar a vida do público ao mostrarem exatamente o que ele precisa fazer para formalizar seu negócio.

Apesar de ser um material de campanha cujo papel é apresentar um passo a passo do processo de formalização, a principal função da linguagem presente na peça ainda é a conativa, pois o texto emprega, em diversos momentos, a $2^{\mathrm{a}}$ pessoa verbal e o verbo no imperativo, como no título "Saiba como se inscrever" e em frases como "Acesse o endereço", "clique no primeiro item”, “Agora você já pode...” etc. O uso do imperativo, acompanhado pelas imagens do leiaute, direciona a ação do receptor para a formalização, num tom quase professoral. Ao mesmo tempo, no contexto da peça, reforça constantemente a opção do público pela formalização, visto que o folder é uma peça destinada àquele empreendedor informal que já se decidiu pela formalização e que, no momento, deseja saber como realizá-la efetivamente.

Quanto à representação social do microempreendedor individual, é interessante notar que a ancoragem acontece por meio de uma única classificação: “empreendedor”. A objetivação, por meio da imagem do empresário, também é diferenciada em relação às outras peças da campanha, já que o MEI é apresentado como um homem idoso. Novamente, não é possível identificá-lo como tal apenas pela imagem. É preciso recorrer ao texto para compreender que ele é um empreendedor em busca da formalização, e por isso está acessando o Portal do Empreendedor: para se tornar um microempreendedor individual.

A identificação buscada pelo Sebrae nesta peça é diferente das demais, a começar pela forma como o empreendedor é apresentado no leiaute: de costas. Além disso, ele é um homem idoso, faixa etária que ainda não havia sido explorada na comunicação. O processo de identificação, então, acontece por meio da comparação social, dessa vez a lateral, ou seja, 
aquela em que o indivíduo receptor da mensagem se vê em iguais condições com o modelo apresentado (CHABROL; RADU, 2010, p. 285 e 286). Ao visualizar um homem idoso utilizando um computador para formalizar seu negócio, o objetivo da comunicação é o de que o trabalhador informal pense que ele é capaz de fazer o mesmo. Em outras palavras, "se ele consegue, eu também consigo".

\subsubsection{Milhão - Lew'Lara|TBWA 2011}

Em 2011, ano em que o Brasil chegou a 1 milhão de microempreendedores individuais, o Sebrae criou uma campanha para comemorar esse número e continuar a incentivar a formalização. $\mathrm{O}$ anúncio de página dupla para revista (figura 21) foi a principal peça de comunicação da campanha. Apesar de apresentar alguns elementos já utilizados em anos anteriores, como o cartaz cujo leiaute remete à comunicação de varejo, o Sebrae inovou ao utilizar verdadeiros microempreendedores individuais no anúncio, e não mais modelos que representam essa figura jurídica.

Figura 21 - Ano 2010, agência Lew’LaralTBWA, campanha “Ei. Tá na hora de se formalizar”. Mídia: folder

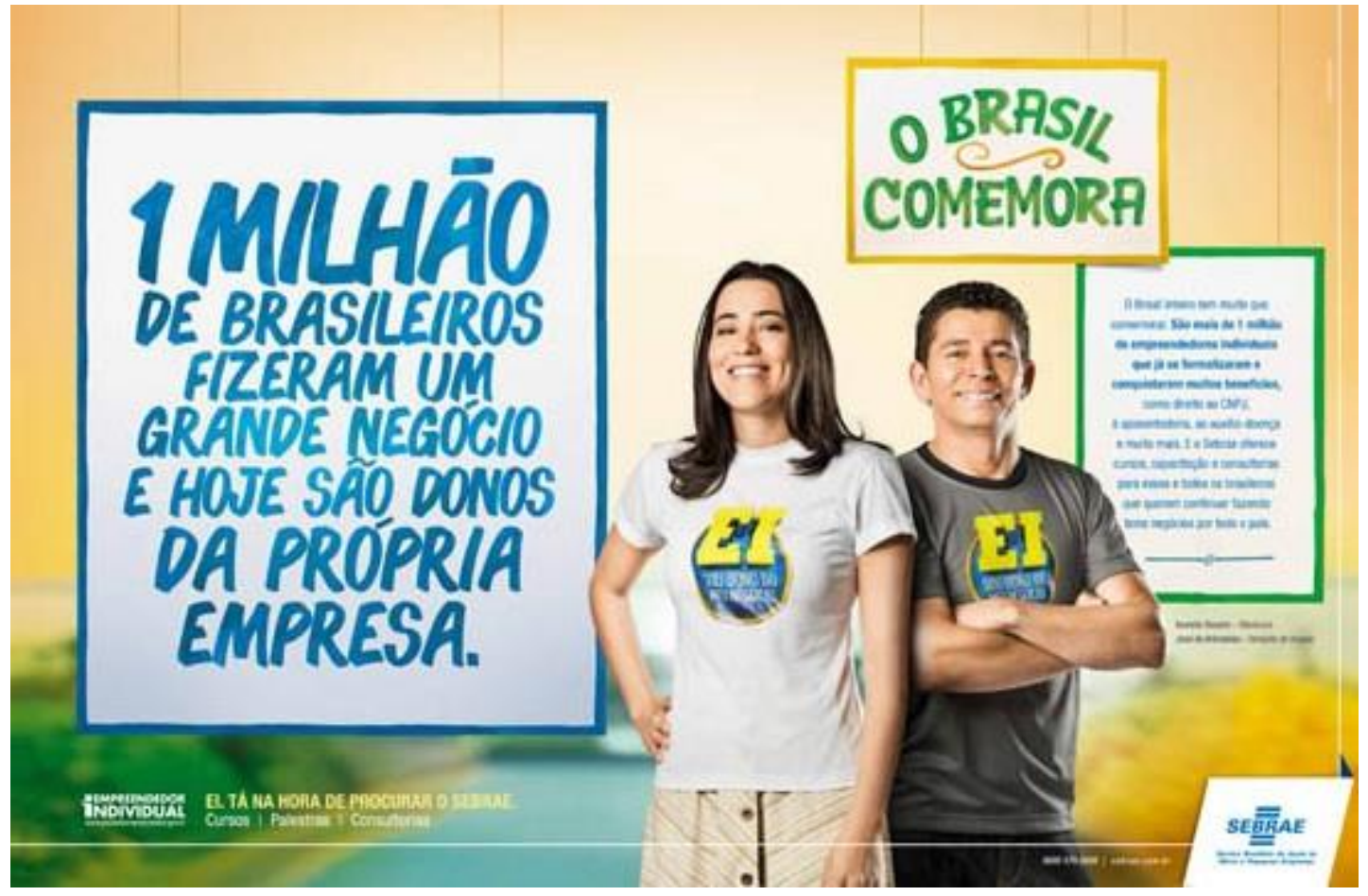

Fonte: material fornecido pela agência Lew'LaralTBWA

A peça mostra uma mulher e um homem, lado a lado. Ambos olham para o receptor da mensagem e sorriem. A mulher está com a mão direita na cintura, veste uma camiseta branca, 
onde se lê "EI. Sou dono do meu negócio" e uma saia longa. O homem, por sua vez, está com os braços cruzados, veste uma camiseta escura com os mesmos dizeres e calça jeans. A foto dos MEI é acompanhada por uma legenda que os identifica para o público: "Ivonete Severo Manicure e José de Arimateia - Varejista de roupas". Ao fundo é possível perceber uma paisagem desfocada.

À esquerda do anúncio, um grande cartaz apresenta a seguinte mensagem: "1 milhão de brasileiros fizeram um grande negócio e hoje são donos da própria empresa”. Ao lado direito, atrás dos modelos, há mais dois cartazes, com as mensagens: “O Brasil comemora” e "O Brasil inteiro tem muito que comemorar. São mais de 1 milhão de empreendedores individuais que já se formalizaram e conquistaram muitos benefícios, como direito ao CNPJ, à aposentadoria, ao auxílio-doença e muito mais. E o Sebrae oferece cursos, capacitação e consultorias para esses e todos os brasileiros que querem continuar fazendo bons negócios por todo o país". Abaixo, o texto "Ei. Tá na hora de procurar o Sebrae. Cursos, palestras, consultorias" finaliza a peça acompanhado do telefone da central de relacionamento, do endereço do Sebrae na internet e da marca da entidade.

A mensagem publicitária deste anúncio, diferentemente das demais, é classificada como testemunhal, pois utiliza dois microempreendedores individuais para auxiliar o processo de persuasão do receptor. Além disso, é também classificada como relacional, uma vez que associa a formalização à sensação de pertencimento, ou seja, à identidade padrão do grupo dos microempreendedores individuais, aqueles que "fizeram um grande negócio" e são beneficiados em diversos aspectos sociais. A imagem, mais uma vez, é explicativa, já que busca ilustrar o MEI.

Em relação às funções da linguagem presentes no anúncio, e diferentemente das outras peças analisadas, há predomínio da função referencial, uma vez que a peça apresenta dados sobre a formalização de maneira clara e assertiva. A persuasão acontece de forma indireta, ficando a função conativa em segundo plano, presente principalmente na frase "Tá na hora de procurar o Sebrae". A função fática, novamente, é identificada na redundância da interjeição "ei”, que aparece tanto no texto quando nas camisetas dos modelos. Por fim, é possível apontar a função emotiva como presente na peça, mesmo que a primeira pessoa verbal não seja utilizada, uma vez que o Sebrae chama atenção para si, como emissor da mensagem, ao mencionar os produtos e serviços que oferece aos microempreendedores individuais.

Sob a ótica da representação social, percebe-se que a ancoragem do conceito acontece por meio dos termos "brasileiros", "donos da própria empresa" e "dono do meu negócio", 
enquanto a objetivação ocorre por meio da imagem do casal: mulher com cerca de trinta anos, vestindo camiseta branca e saia listrada, e homem de 40 anos, vestindo camiseta e calça jeans.

É interessante notar como o uso de microempreendedores individuais reais no anúncio publicitário não elimina a complementaridade necessária entre texto e imagem. Mais uma vez, nota-se que a representação social do MEI não consegue ser sustentada apenas visualmente. As imagens demandam conteúdo textual para serem comunicadas efetivamente, ou seja, para ativar na memória do receptor a imagem mental que ele tem do conceito de empresário. O público identifica a modelo como microempreendedora individual devido ao texto do anúncio, ao texto estampado em sua blusa e à legenda da foto, que identifica, inclusive, sua atividade profissional: manicure. O mesmo ocorre para o homem, na medida em que nenhum elemento gráfico consegue identificá-lo como um microempreendedor individual varejista de roupas.

Essas informações são fundamentais para que o processo de identificação seja deflagrado e conduzido corretamente, ativando a comparação com a identidade padrão de empreendedor desejada, legitimando o comportamento do MEI, caso a identificação ocorra, ou, em caso negativo, motivando a formalização e a mudança e categoria social do empreendedor que trabalha na informalidade.

Figura 22 - Ano 2011, agência Lew'LaralTBWA, campanha "Semana do Empreendedor Individual". Mídia: filme

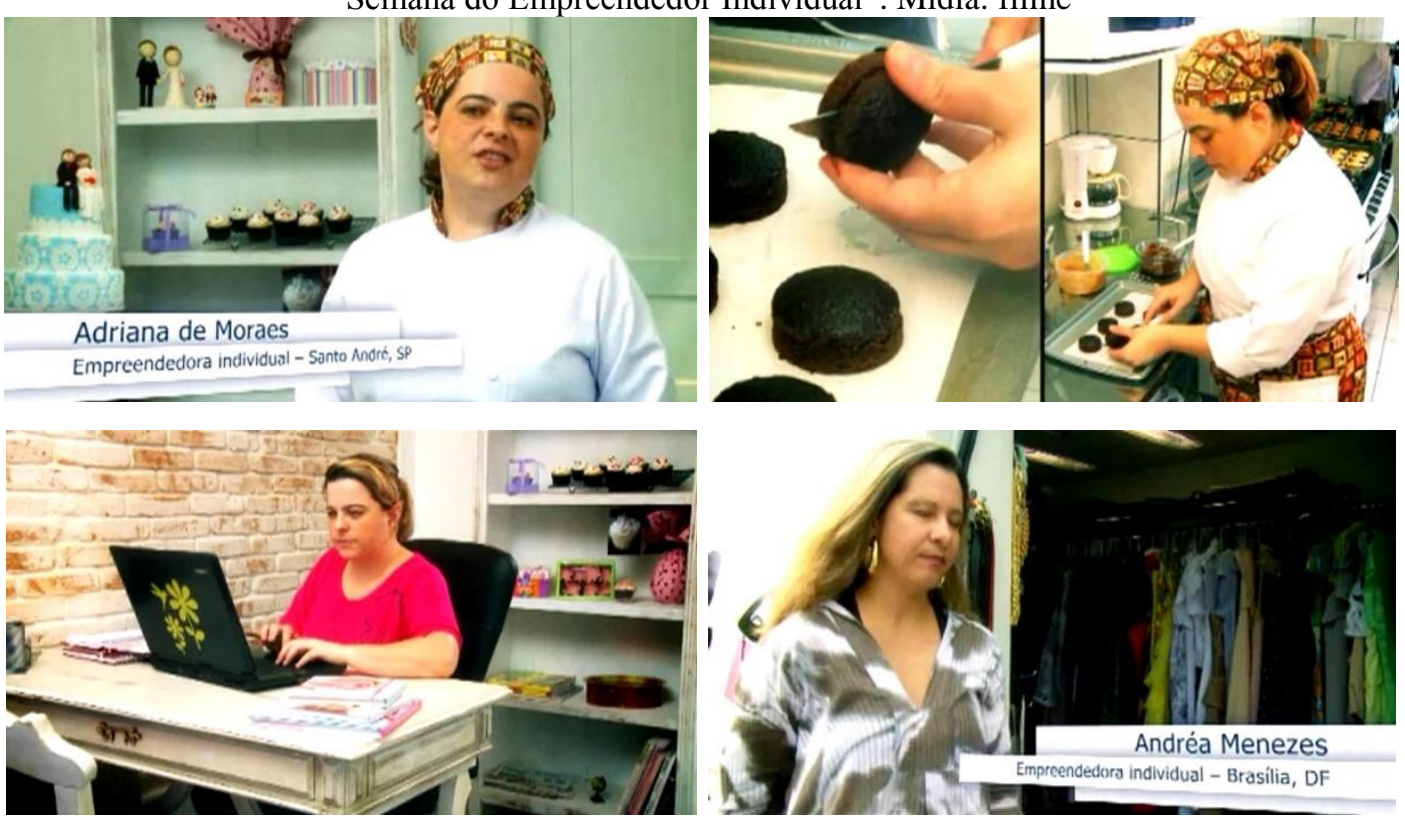



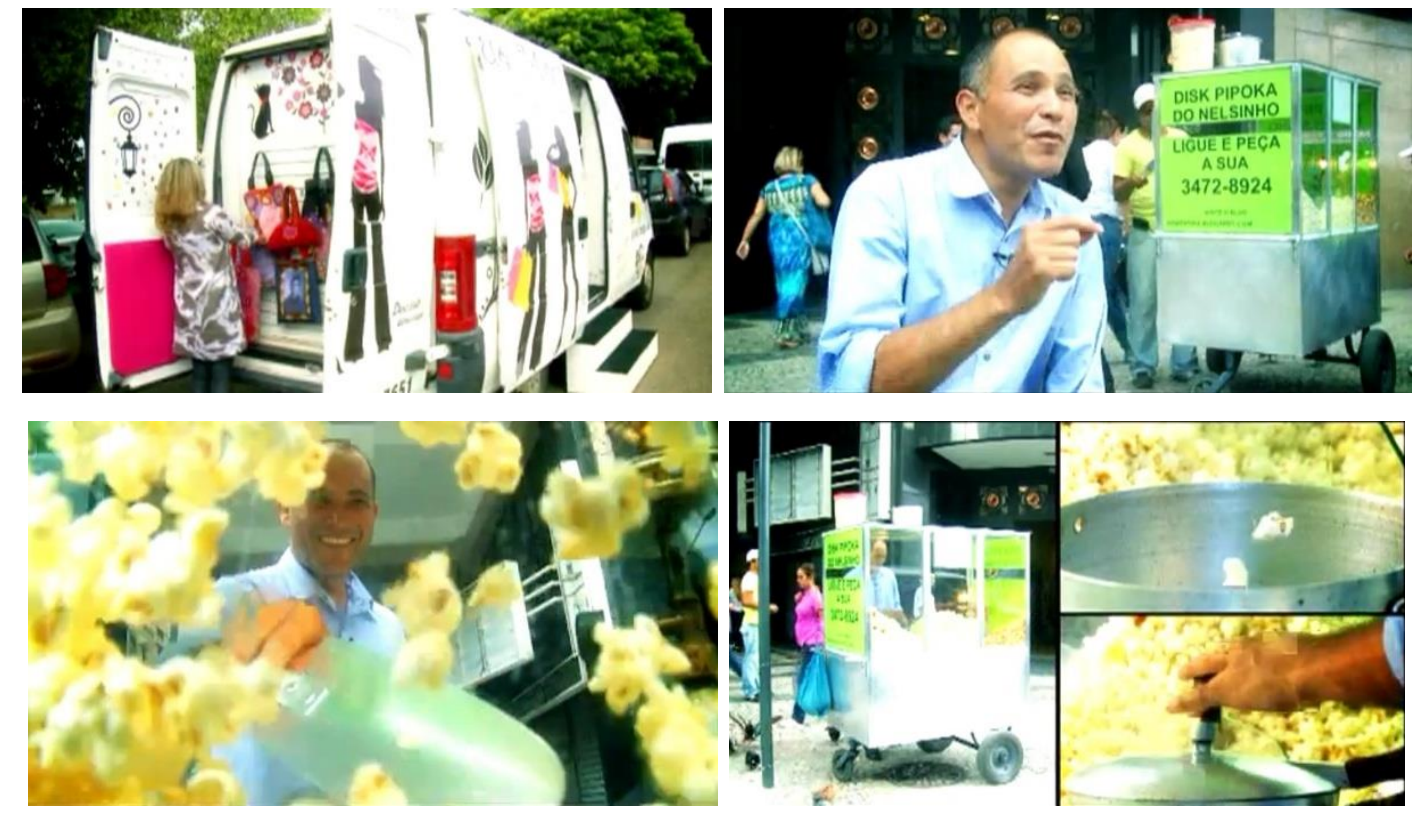

Fonte: material fornecido pela agência Lew’LaralTBWA

A segunda peça a utilizar a imagem do microempreendedor individual é o filme da campanha (figura 22), criado em formato de documentário e também com personagens reais, ou seja, verdadeiros MEI. Não há locução e as entrevistas são apresentadas no início do vídeo com o seguinte lettering: "Julho de 2009 marca o início de um novo tempo para quem trabalha por conta própria no Brasil. Entra em vigor a Lei do Empreendedor Individual. Uma oportunidade para conquistar direitos e melhorar de vida. Hoje, comemoramos UM MILHÃO de empreendedores individuais no Brasil. Conheça agora algumas de suas histórias”.

São apresentadas três histórias. A primeira delas é a de Adriana de Moraes, arquiteta de São Paulo que, ao perder o emprego, decidiu empreender no ramo culinário, juntando artesanato e gastronomia. Adriana decidiu formalizar o negócio quando começou a perder vendas por não emitir nota fiscal. A segunda história é a de Andréa Menezes. Afastada do trabalho no funcionalismo público por motivos de saúde, Andréa decidiu empreender montando uma boutique móvel em Brasília, onde revende peças de roupa e acessórios e vai até suas clientes, um grande diferencial do empreendimento. Andréa buscou a formalização para conseguir comprar seus produtos de grandes fornecedores de São Paulo, que vendem apenas atacado para pessoas jurídicas. A terceira e última história apresentada no filme é a de Nelsinho Pipoqueiro, microempreendedor individual do Rio de Janeiro. Trabalhando no centro da cidade, Nelsinho inovou ao criar o "Disk-Pipoka", um serviço de entrega de pipoca em residências e edifícios comercias do centro da cidade. O motivo da formalização para Nelsinho foi, também, a necessidade de oferecer seus serviços a empresas que exigem nota fiscal. Para finalizar o filme, 
há outro lettering acompanhado pela logomarca do Sebrae: "Microempreendedor individual, uma conquista dos brasileiros".

A mensagem do filme é claramente testemunhal, pois demonstra o sucesso da implementação da nova lei ao apresentar três casos de sucesso. A imagem do microempreendedor individual, assim como nas outras peças analisadas até o momento, permanece explicativa, já que busca ilustrar quem é o MEI.

A principal função da linguagem desta peça é a referencial, já que apresenta como uma prestação de contas à sociedade os resultados da implementação da lei e da formalização do primeiro milhão de microempreendedores individuais. $\mathrm{O}$ momento em que a função conativa se faz presente de forma mais explícita acontece no fim do filme, quando Nelsinho Pipoqueiro afirma: "O sucesso ideal de um empreendedor é ele adotar a filosofia de deixar seu cliente feliz. Seja na pipoca, seja na empresa, seja onde for. Se você trabalhar com carinho, se você acreditar no que você faz e deixar o seu cliente feliz o seu sucesso é garantido. Seja um empreendedor individual, seja um cara bacana com as leis e bacana com você mesmo".

Nesse contexto, a representação social do MEI se dá da seguinte maneira: ancoragem por meio dos termos "quem trabalha por conta própria no Brasil" e "cara bacana com as leis", e objetivação por meio dos três microempreendedores individuais: uma mulher jovem, uniformizada em seu ambiente de trabalho; outra mulher mais madura, com cerca de 40 anos, que veste roupa estampada e trabalhando em seu negócio; e um homem, também com cerca de 40 anos, que veste blusa social azul. Mais uma vez é necessária a interação entre imagens e textos (neste caso, os depoimentos) para que o conceito de microempreendedor individual seja comunicado e o processo de identificação deflagrado.

Este processo, por sua vez, é desencadeado pela apresentação dos três segmentos de negócio no filme. A intenção do anunciante é despertar, no público-alvo, o sentimento de orgulho por pertencer ao grupo dos microempreendedores individuais, caso ele já seja formalizado como tal, ou despertar, naqueles que ainda trabalham na informalidade, a admiração pelo MEI e a vontade de se formalizar. A questão referente à mudança de categoria social é trabalhada de maneira bastante persuasiva pela comunicação, mesmo que a comparação entre as categorias seja sugerida de maneira sutil.

\subsubsection{Sebrae Empreendedor - Giacometti 2012}

No ano de 2012, o Sebrae criou e veiculou uma pequena campanha na internet para divulgar as oficinas do SEI - Sebrae Empreendedor Individual, cujos conteúdos estavam 
disponíveis, além de presencialmente, também via celular. Foram criados dois banners, veiculados em sites específicos, além do portal do Sebrae.

Ambas as peças são muito parecidas. A primeira delas (figura 23) tem fundo desfocado em cor verde, e a foto de uma mão com o dedo indicador levantado em close up, ocupando grande parte do leiaute. Há um homem desenhado com caneta esferográfica no dedo. Ele olha para a imagem de um celular que está logo atrás da mão e sorri. Veste blusa e calça sociais, além de gravata. No bolso da camisa há duas canetas. O aparelho celular posicionado logo atrás está ligado e sua tela mostra a seguinte mensagem: "Seu celular toca até negócio. Faça pelo celular as oficinas do SEI (Sebrae Empreendedor Individual). Inscreva-se gratuitamente pelo site www.ead.sebrae.com.br e aproveite". Abaixo do texto, é exibida a logomarca do SEI. O banner é assinado com a marca do Sebrae, porém em um local pouco comum em peças publicitárias: o canto superior esquerdo.

Figura 23 - Ano 2012, agência Giacometti, campanha “Sebrae Empreendedor”. Mídia: web

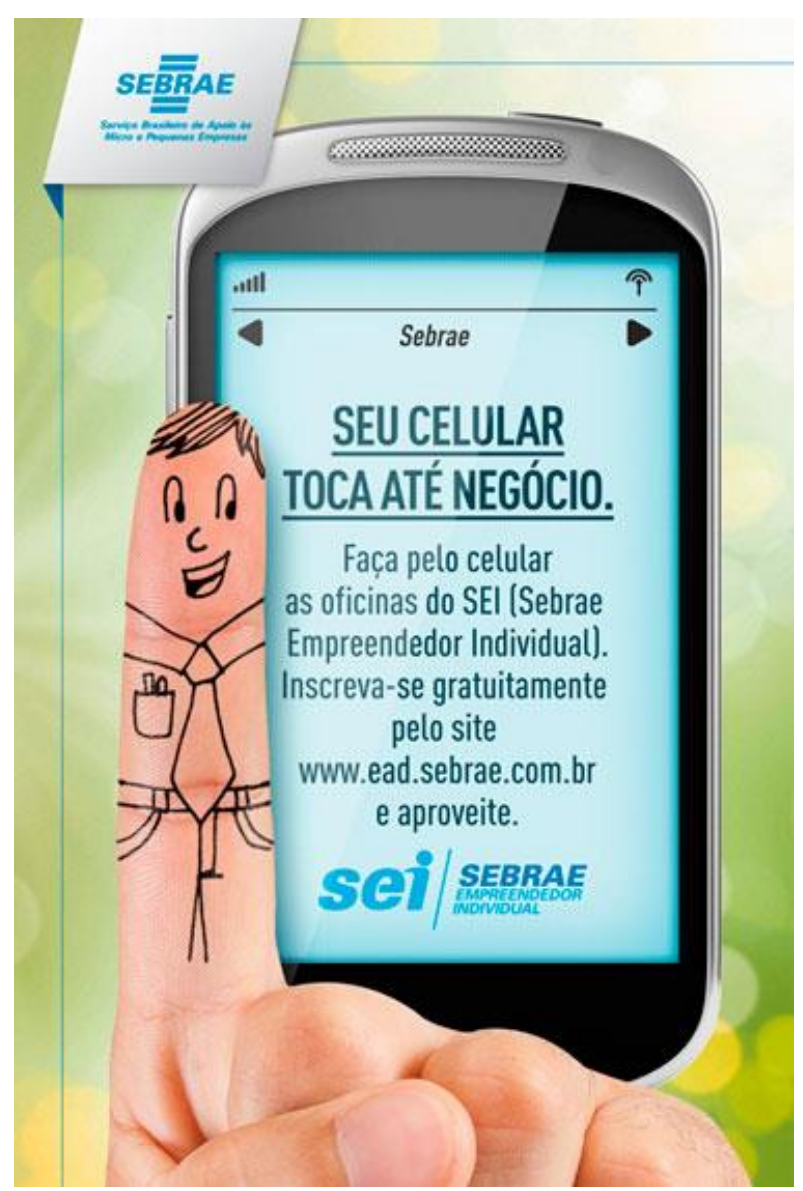

Fonte: material fornecido pela agência Giacometti

O segundo banner, de formato horizontal, é apresentado na figura 24. Também apresenta fundo verde desfocado e a imagem do dedo indicador e do aparelho celular. O homem 
desenhado no dedo, porém, é diferente: é aparentemente mais jovem, sorri para a câmera e veste blusa e calça sociais, porém sem gravata. O celular traz a seguinte mensagem: "Seu celular vai ajudar seu negócio a ser desbloqueado". Ao lado direito da imagem, mais texto: "Faça pelo celular as oficinas do Sebrae Empreendedor Individual. Clique e inscreva-se”. A logomarca do SEI é posicionada logo abaixo e, curiosamente, a peça não é assinada com a marca do Sebrae.

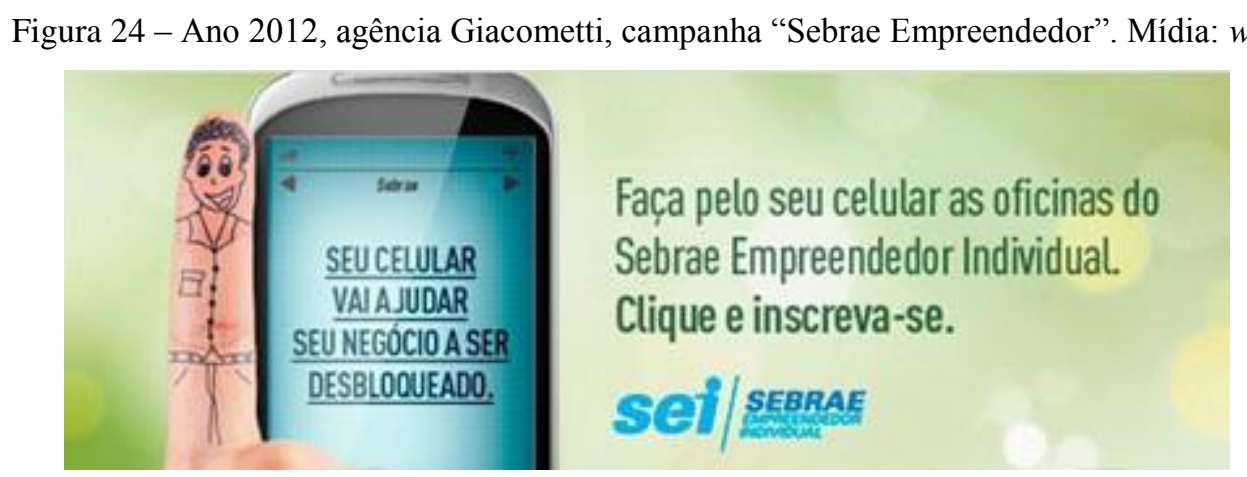

Fonte: material fornecido pela agência Giacometti

A mensagem de ambas as peças é instrumental, uma vez que a divulgação das oficinas do SEI é feita de maneira bem objetiva: para melhorar seu negócio o microempreendedor individual precisa cursar as oficinas. As imagens, em ambos os casos, são explicativas, já que a ilustração busca representar o MEI. Quanto às funções de linguagem, a conativa é claramente a função predominante nas peças, uma vez que o texto de ambas utiliza o verbo no imperativo e a $2^{\text {a }}$ pessoa do singular, como: "seu celular", "faça pelo celular", "inscreva-se gratuitamente”, "aproveite", "clique e inscreva-se", "seu negócio".

Além disso, essas são as primeiras peças analisadas que não buscam explicar o conceito de microempreendedor individual e ancorá-lo pelo uso de expressões como "quem trabalha por conta própria", o que caracteriza a função metalinguística da linguagem, uma vez que o emissor assume que o receptor da mensagem já está familiarizado com aquele conceito e, assim, ele fica implícito na comunicação. A objetivação, porém, acontece por meio das ilustrações: dois homens, com roupas sociais, representam o MEI. No entanto, só é possível identificá-los como microempreendedores individuais devido ao texto que menciona o produto vendido: SEI, Sebrae Empreendedor Individual.

Entretanto, o processo de identificação do público-alvo não é a principal função das peças, uma vez que o objetivo de comunicação é vender a capacitação SEI, e não a formalização. O produto anunciado já é um filtro para a comunicação, pois é direcionado ao microempreendedor individual. A ilustração, nesse contexto, auxilia a comunicação como um 
elemento extra que compõe o leiaute e atrai a atenção do público para as peças inseridas no cenário web, onde há grande concorrência visual.

\subsubsection{Sebrae 40 Anos - Giacometti 2012}

Ainda em 2012, foi criada e veiculada uma grande campanha institucional para comemorar os 40 anos do Sebrae (SEBRAE, 2012c). Com o mote "O negócio é acreditar", a agência Giacometti utilizou como argumento de comunicação o sonho do empreendedorismo e como os empreendedores caracterizam-se por serem pessoas positivas, que acreditam em seus negócios e em um futuro melhor. A campanha foi direcionada a todos os públicos do Sebrae e foram criadas peças específicas para cada um deles: microempreendedor individual, microempresa, empresa de pequeno porte e produtor rural. Serão analisados aqui o anúncio que traz a imagem representativa do MEI, o filme da campanha que retrata esse público e um documentário sobre uma cliente do Sebrae que é microempreendedora individual.

Figura 25 - Ano 2012, agência Giacometti, campanha "Sebrae 40 anos”. Mídia: revista

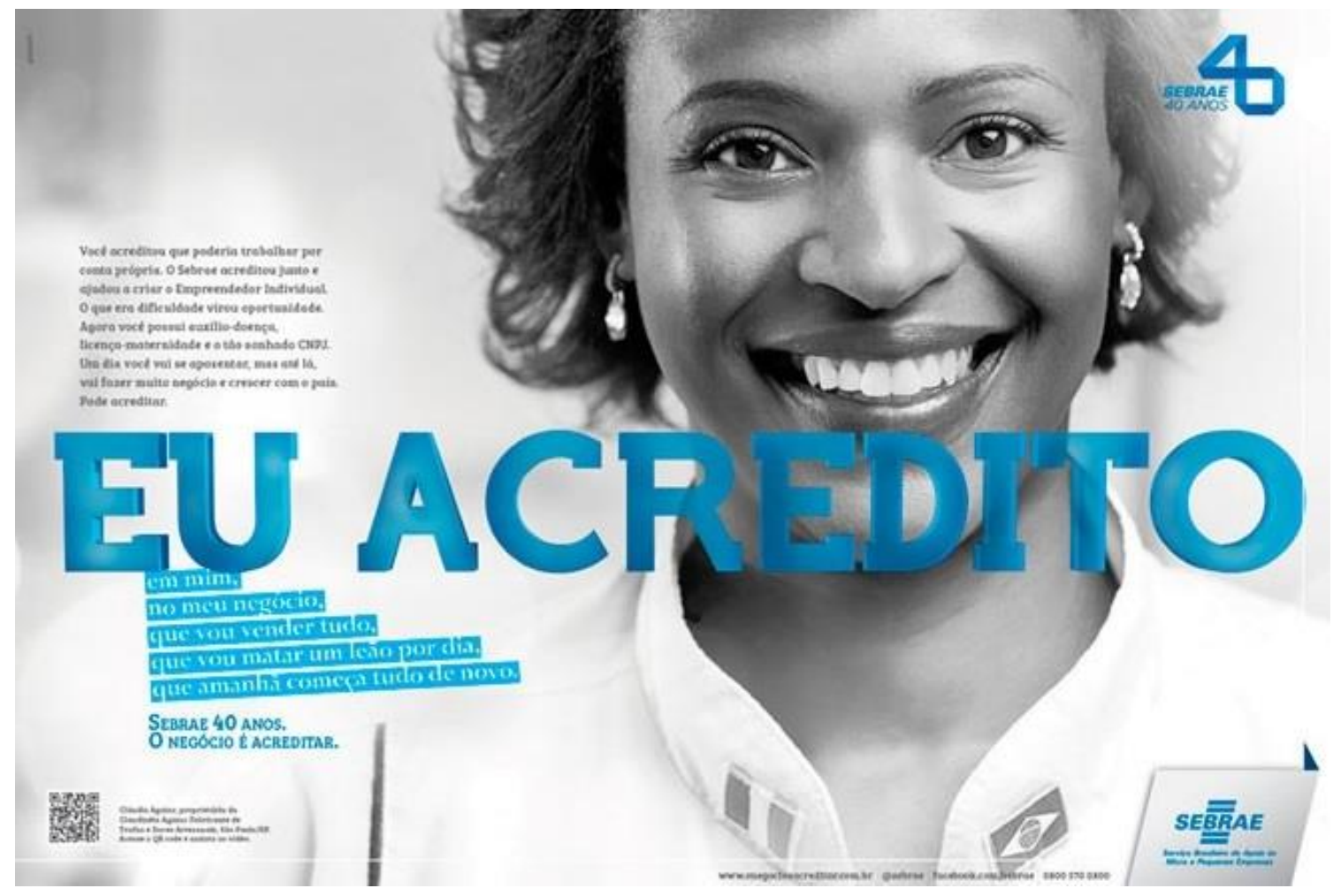

Fonte: material fornecido pela agência Giacometti

O anúncio de revista em página dupla (figura 25) apresenta a imagem em preto e branco de uma mulher negra, fotografada em close up. Ela sorri para a câmera e está uniformizada 
como chef de cozinha. Sua roupa tem, na gola, duas bandeiras, uma da Itália e outra do Brasil. O título do anúncio é apresentado em azul, cor da marca do Sebrae, e ocupa a parte frontal de todo o leiaute, ficando à frente, inclusive, da foto. O texto "Eu acredito" serve como referência para as várias possibilidades que se apresentam logo abaixo, à esquerda: "em mim / no meu negócio / que vou vender tudo / que vou matar um leão por dia / que amanhã começa tudo de novo". Essa sequência é finalizada com o texto "Sebrae 40 anos. O negócio é acreditar". Na parte superior esquerda do anúncio há, ainda, outro texto: "Você acreditou que poderia trabalhar por conta própria. O Sebrae acreditou junto e ajudou a criar o Empreendedor Individual. O que era dificuldade virou oportunidade. Agora você possui auxílio-doença, licença-maternidade e o tão sonhado CNPJ. Um dia você vai se aposentar, mas até lá, vai fazer muito negócio e crescer com o país. Pode acreditar". A parte inferior do anúncio possui um QR Code, código eletrônico lido por celulares que ativa, no navegador de internet do aparelho, um vídeo da campanha do Sebrae. A legenda da foto direciona o receptor e apresenta a microempreendedora individual: "Cláudia Aguiar, proprietária da Claudinéia Aguiar Fabricante de Trufas e Doces Artesanais, São Paulo/SP. Acesse o $Q R$ code e assista ao vídeo". Outras informações como o endereço do hotsite da campanha, o telefone da central de relacionamento e a logomarca da entidade assinam a peça.

A mensagem publicitária, neste caso, é testemunhal, pois se baseia na figura da empresária para comunicar. Há, no entanto, aspectos instrumentais e relacionais na comunicação, uma vez que o anúncio é praticamente uma homenagem àqueles que já são microempreendedores individuais. Os benefícios adquiridos pelo MEI são mencionados na peça, porém não há apelo explícito pela formalização. Assim, a instrumentalidade da mensagem está na informação apresentada sobre os direitos de quem trabalha na formalidade, e o aspecto relacional é identificado na associação entre formalização e pertencimento ao grupo dos microempreendedores individuais. Assim como nas outras peças analisadas, a imagem publicitária se esforça para ilustrar o microempreendedor individual e é, por isso, classificada como explicativa.

A função da linguagem predominante na peça é, diferentemente das outras imagens analisadas, a função emotiva. Apesar da utilização da $1^{\text {a }}$ pessoa verbal e do caráter emocional percebido em expressões como "eu acredito", "no meu" e "que vou", a função emotiva é identificada principalmente pelo objetivo da peça: celebrar os 40 anos do Sebrae, focando a mensagem, assim, no emissor. Em outras palavras, o anúncio afirma que o Sebrae reconhece o sonho do empreendedorismo e que ajudou a criar a figura jurídica do MEI. 
As funções conativa e referencial também estão presentes e são identificadas pelo uso de expressões como "você acreditou", "você possui", "você vai" e "pode acreditar" e pelas informações apresentadas sobre a formalização, respectivamente. Percebe-se que o anúncio não busca persuadir o receptor da forma publicitária clássica, ou seja, utilizando verbos no imperativo e defendendo pontos de vista de maneira enfática. No entanto, busca persuadir ao apresentar os benefícios da formalização por meio da história da empresária, característica da mensagem testemunhal. Além disso, a imagem em preto e branco e close up traz dramaticidade à cena apresentada, caracterizando a função conativa associada a recursos poéticos. Nesse sentido, a função poética pode ser identificada no título da peça, que ocupa todo o leiaute, ficando inclusive à frente da imagem, e é o único elemento colorido do anúncio, carregado de importância.

O título também remete à função fática, uma vez que o anúncio sugere a repetição da expressão "eu acredito" a cada frase apresentada abaixo do texto, gerando redundância: "em mim / no meu negócio / que vou vender tudo / que vou matar um leão por dia / que amanhã começa tudo de novo". O verbo acreditar é repetido ainda mais uma vez, no slogan da campanha: "O negócio é acreditar".

Em relação à representação social, o conceito de MEI é ancorado por expressões como "meu negócio", "trabalhar por conta própria", "proprietária" e "Fabricante de Trufas e Doces Artesanais". A objetivação é centrada na imagem da mulher negra, com cerca de 40 anos, uniformizada. É possível ainda constatar o mesmo que nas outras análises realizadas: a imagem, por si só, não é capaz de comunicar o conceito, e por isso necessita do auxílio do texto. Nesse sentido, a frase "Cláudia Aguiar, proprietária da Claudinéia Aguiar Fabricante de Trufas e Doces Artesanais, São Paulo/SP” ancora a imagem do anúncio. Assim, o receptor compreende que a modelo é uma empresária. O texto "Você acreditou que poderia trabalhar por conta própria. O Sebrae acreditou junto e ajudou a criar o Empreendedor Individual" também ancora o conceito, dessa vez diretamente ao MEI. A objetivação, ou seja, a transformação do conceito em imagem, é mais complexa. O elemento utilizado pelo emissor na busca pela materialização recai sobre o uniforme da empresária. Esse, no entanto, permite ao receptor diversas interpretações, fazendo com que a construção do significado de microempreendedor individual aconteça, mais uma vez, pela dinâmica entre texto e imagem.

Como já dito anteriormente, é fundamental que o anúncio comunique, de forma clara, o conceito de MEI, uma vez que esse é o estímulo que dará início ao processo de identificação no receptor. A identidade padrão ativada deverá ser a identidade ligada a conceitos como empresário, empreendedor, trabalhador por conta própria, dono do próprio negócio, além do 
próprio conceito de microempreendedor individual. Neste anúncio, a conexão com o público é buscada por meio do reconhecimento de características empreendedoras como persistência, comprometimento e responsabilidade. O Sebrae mostra-se solidário às adversidades enfrentadas pelo MEI no seu dia a dia e utiliza a imagem de uma verdadeira microempreendedora individual para objetivar não apenas o conceito, mas também o resultado do apoio da entidade ao empreendedorismo.

Assim, idealmente, o público deverá se perceber como Claudinéia, uma microempreendedora individual cujo negócio obteve sucesso com o apoio do Sebrae. No caso do empreendedor informal, a intenção é que ele vislumbre a possibilidade de ser como a empresária ao formalizar seu negócio.

Figura 26 - Ano 2012, agência Giacometti, campanha "Sebrae 40 anos". Mídia: revista
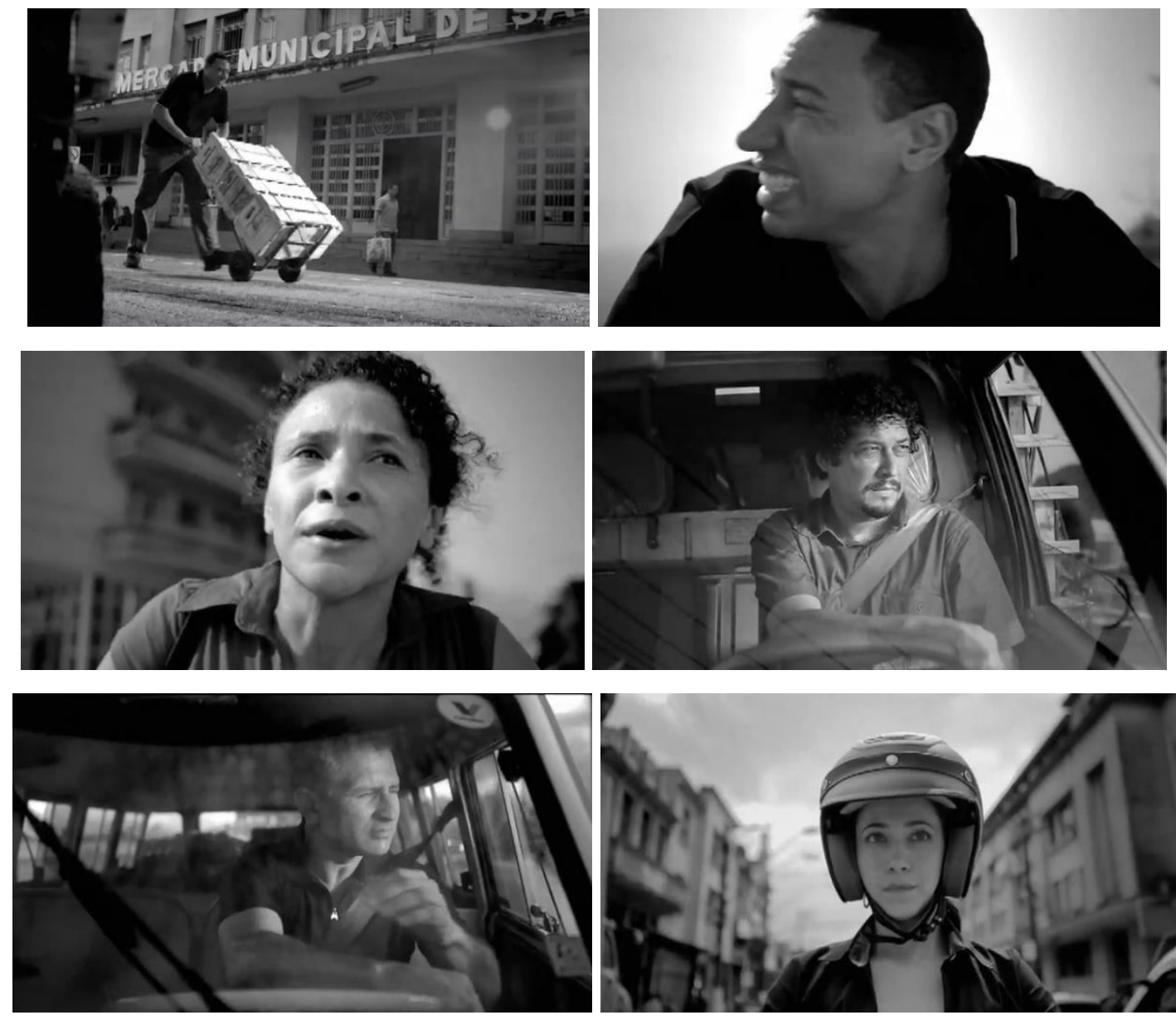

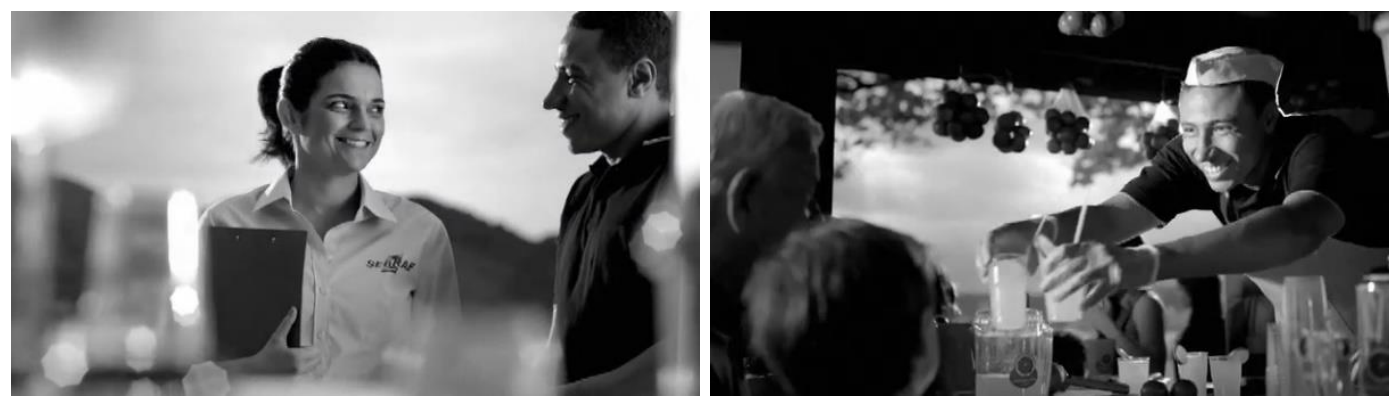

Fonte: material fornecido pela agência Giacometti

O filme da campanha (figura 26) mantém a estética do preto e branco, tem duração de 1 minuto e traz a locução do ator e diretor Antônio Abujamra: "Sabe aquele dia em que a gente acorda e diz: "Hoje, não"? Você diz: "Hoje, sim!". Você é daquele tipo de pessoa rara, que transforma medo em coragem. Nada contra a correnteza, mata um leão por dia e mesmo assim segue em frente. Já até pensou em desistir, mas uma força anterior faz você acreditar que vale a pena. Louco? Não. Você não é louco! É empreendedor, brasileiro, e nasceu para acreditar. E a gente acredita junto. Em você e no país. Sebrae 40 anos. O negócio é acreditar”.

Ao longo da locução, é retratado o dia a dia de diversos microempreendedores individuais. Os personagens realizam as mesmas ações e são substituídos durante as cenas. Esse recurso tem como objetivo retratar diferentes MEI: o rapaz jovem, pardo, que empurra o carrinho de mão em frente a um mercado é substituído repentinamente por uma mulher de meia idade, cabelos encaracolados, realizando a mesma ação. Um senhor de cabelos grisalhos aparece no lugar de um homem pardo, de barba, que dirigia uma camionete, enquanto uma mulher jovem pilota uma motocicleta.

Apesar das substituições, o primeiro rapaz a aparecer no filme é o protagonista, uma vez que aparece mais vezes e é possível identificar, ao longo do vídeo, sua história como empreendedor. Ele chega cedo ao mercado, para comprar matéria-prima para o seu negócio: laranjas. Carrega essa mercadoria até sua barraca, na beira da praia. Limpa o estabelecimento, veste seu uniforme de trabalho e encerra o filme servindo suco a seus clientes. O filme é assinado pela logomarca do Sebrae, o único elemento em toda a peça que apresenta cor: o azul da marca.

A mensagem dessa peça de comunicação é classificada como relacional, já que faz uso de argumentos emocionais para comunicar: o microempreendedor individual é aquele que tem coragem, que mata um leão por dia, que não desiste porque sabe que vale a pena continuar. A imagem, assim como em outras peças já analisadas, é explicativa, pois busca retratar o MEI. 
Muitas imagens mentais são evocadas pelo texto por meio de expressões como "pessoa rara", "nada contra a correnteza", "segue em frente" e "não é louco".

Assim como o anúncio da campanha, a função da linguagem predominante nesta peça é a função emotiva, e não a conativa, como na maioria das peças analisadas. A campanha é comemorativa dos 40 anos da entidade, e o comportamento e a personalidade do empreendedor são legitimados e atrelados ao emissor da mensagem na afirmação "e a gente acredita junto". Assim, o foco da mensagem é centrado no emissor, que celebra 40 anos e acredita, juntamente com o brasileiro, no valor do empreendedorismo.

Não há menção no texto ao microempreendedor individual e nem aos benefícios da formalização, o que caracteriza a função metalinguística, uma vez que o conceito fica subentendido no filme, demonstrando que, de maneira ideal, é conhecido tanto pelo emissor quanto pelo receptor da comunicação. A função poética também pode ser percebida pela importância da locução, que traz densidade e expressividade a um filme publicitário recheado de imagens em preto e branco, onde o único elemento com cor é a assinatura do filme, que aparece em azul. Já a função conativa está presente de maneira sutil, pois a peça busca convencer o público de que o Sebrae reconhece e acredita nele como empreendedor. Há forte presença da $2^{\mathrm{a}}$ pessoa verbal, em frases como "Você é daquele tipo de pessoa rara, que transforma medo em coragem". Porém, sem verbo no imperativo.

Quanto à representação social do MEI, não há ancoragem clara do conceito, já que ele é sequer mencionado na peça. A objetivação, por sua vez, acontece por meio da imagem dos empreendedores: rapaz jovem, mulher de meia idade, senhor de cabelos grisalhos, homem com cerca de 40 anos. É interessante notar que todos eles vestem camisa estilo polo, com gola. $\mathrm{O}$ protagonista do filme, que aparece trabalhando em seu negócio, é visto uniformizado com chapéu e avental.

Diferentemente das outras peças publicitárias analisadas, só é possível compreender que esse filme representa o dia a dia do microempreendedor individual porque, ao receber as campanhas do Sebrae para análise, o material estava classificado como tal. É possível compreender que os personagens são empreendedores. Porém, não é possível caracterizá-los como MEI, pois a figura jurídica nem mesmo é mencionada na peça, o que inclusive caracterizou a função metalinguística da linguagem. A necessidade de interação entre texto e imagem é tão importante que prejudicou a comunicação, uma vez que o conceito não foi mencionado pela locução e, assim, não foi comunicado efetivamente ao receptor da mensagem.

Assim como o anúncio da campanha de 40 anos, o filme busca a identificação do público por meio da comparação social com a personagem Claudinéia. O objetivo da comunicação é 
que o receptor da mensagem veja na microempreendedora individual um exemplo de superação e atribua seu sucesso a suas características empreendedoras, mas, também, ao apoio recebido do Sebrae. O público que já é MEI sentirá orgulho de sua formalização e do pertencimento a essa categoria social reconhecida e valorizada. O empreendedor informal, por sua vez, não se reconhecerá em Claudinéia e sentirá a necessidade de se formalizar para pertencer à categoria de MEI e, assim, obter o mesmo sucesso que a empresária.

Figura 27 - Ano 2012, agência Giacometti, campanha "Sebrae 40 anos”. Mídia: filme
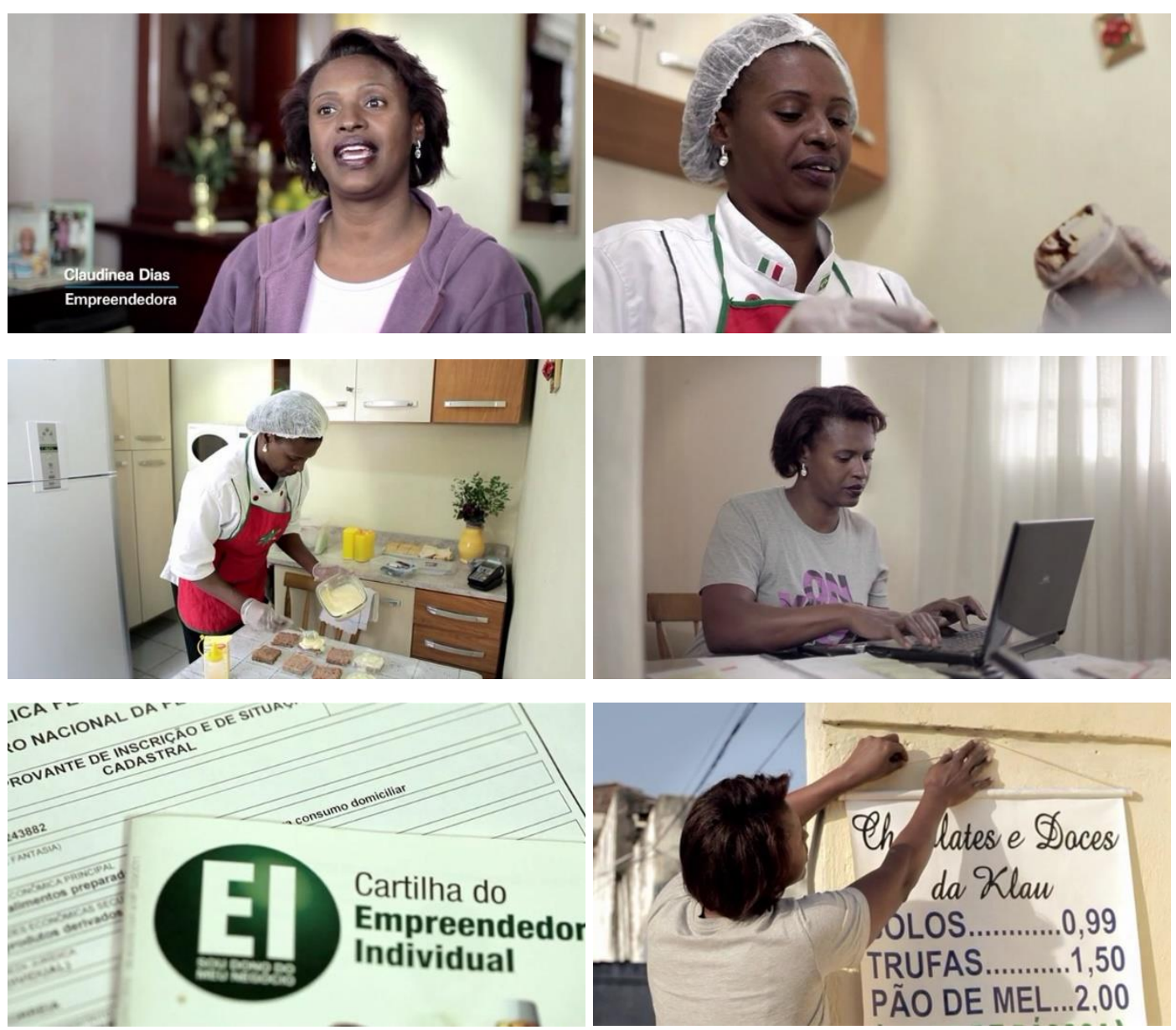

Fonte: material fornecido pela agência Giacometti

A última peça da campanha de 40 anos do Sebrae a apresentar o microempreendedor individual é um pequeno documentário (figura 27), com duração de pouco mais de 2 minutos, que conta a história de Claudinéia Aguiar, a empresária que ilustra o anúncio da campanha. Depois de fazer um curso de ovos de Páscoa, Claudinéia começou a fazer bombons para aumentar a renda familiar. Seus primeiros clientes foram seus colegas de trabalho, que a incentivaram a seguir empreendendo. Depois de ser demitida, resolveu seguir como 
empreendedora. Com dificuldades de gestão, procurou o Sebrae e se formalizou. Passou a vender seus chocolates para os mercados do bairro e conseguiu fazer seu negócio crescer.

A mensagem do filme é testemunhal, enquanto a imagem de Claudinéia é explicativa, pois ela ilustra a figura jurídica do MEI. A função da linguagem predominante na comunicação é a referencial, pois a história de empreendedorismo é o foco do minidocumentário. A função emotiva também está presente devido à participação do Sebrae na narrativa. Somente com o apoio da entidade a empresária consegue organizar a gestão de sua empresa e, assim, obtém sucesso.

A representação social do MEI, por sua vez, ocorre pela ancoragem do conceito no termo "empreendedora" e pela objetivação na imagem de Claudinéia: mulher negra, madura, com cerca de 40 anos de idade. A identificação do público com a representação da microempreendedora individual ocorre da mesma forma que nas peças anteriores, ou seja, por meio da comparação social do receptor com a personagem.

\subsubsection{MEI Card - Giacometti 2013}

A primeira ação de comunicação para o microempreendedor individual no ano de 2013 foi a criação e distribuição da chamada "Caderneta do MEI", ou MEI Card, uma espécie de folder de tamanho reduzido, ideal para ser guardada no bolso, que foi enviada, via Correios, para todos os microempreendedores individuais formalizados até aquele ano (figura 28).

Figura 28 - Ano 2013, agência Giacometti, campanha "MEI Card". Mídia: cartilha

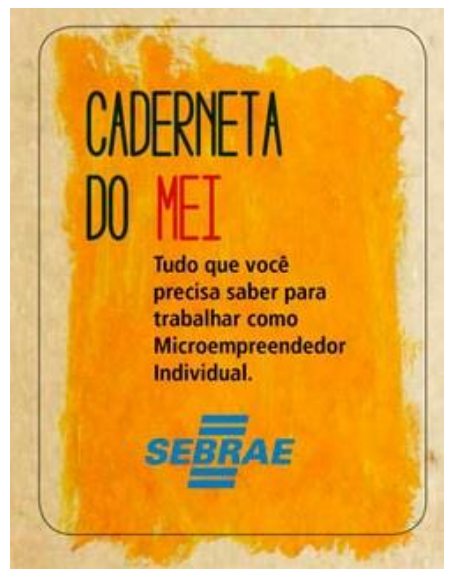



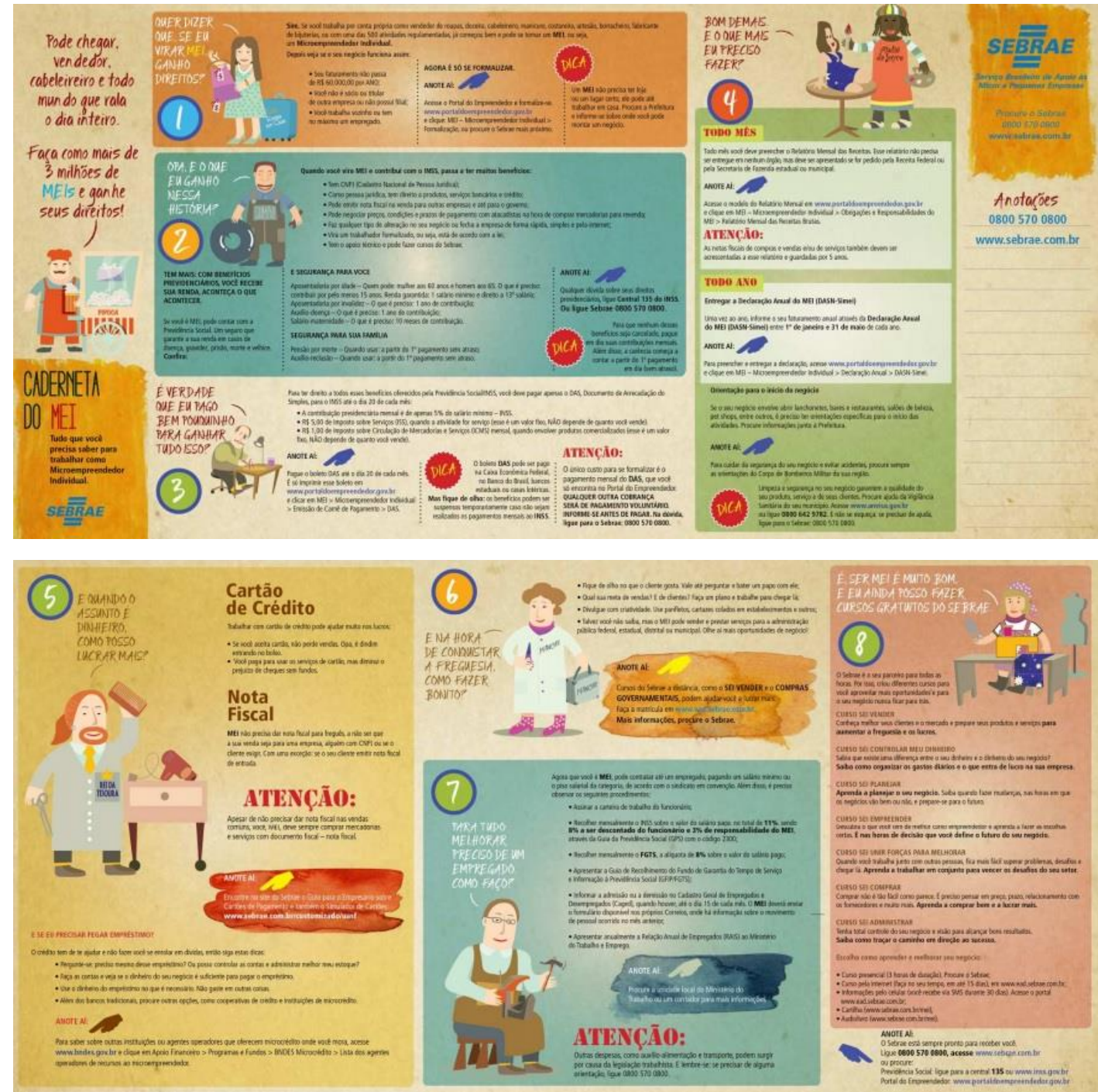

Fonte: material fornecido pela agência Giacometti

O material traz informações objetivas e importantes sobre os direitos e deveres do MEI. O título afirma: "Caderneta do MEI: Tudo que você precisa saber para trabalhar como Microempreendedor Individual”. Ao abrir o folder, há uma ilustração de um pipoqueiro com um balão de diálogo: "Pode chegar, vendedor, cabeleireiro e todo mundo que rala o dia inteiro. Faça como mais de 3 milhões de MEIs e ganhe seus direitos!". O material é dividido em oito seções, cada uma delas abordando um tópico diferente e todas ilustradas por um microempreendedor individual. A seção 1 fala sobre os direitos do microempreendedor individual. Uma sacoleira, ilustrada com roupas e uma mala, pergunta: "Quer dizer que, se eu virar MEI, ganho direitos?”. A segunda seção traz a imagem de um borracheiro: “Opa, e o que eu ganho nessa história?”. A terceira, um joalheiro que pergunta: “É verdade que eu pago bem pouquinho para ganhar tudo isso?", seguido de um artesão: "Bom demais. E o que mais eu preciso fazer?". A quinta seção mostra a imagem de um cabeleireiro e a pergunta dele é: "E 
quando o assunto é dinheiro. Como posso lucrar mais?". A manicure ilustra a sexta seção: "E na hora de conquistar a freguesia, como fazer bonito?", e o sapateiro, a sétima: "Para tudo melhorar preciso de um empregado. Como faço?". A última seção mostra uma costureira que afirma: "É, ser MEI é muito bom. E eu ainda posso fazer cursos gratuitos do Sebrae".

A mensagem da peça é claramente instrumental, pois trata-se de um material com orientações sobre os direitos e deveres do empreendedor formalizado como MEI. As ilustrações são explicativas, uma vez que exibem diversas ocupações cuja formalização como microempreendedor individual é permitida pela legislação. É interessante notar que, apesar do material ter sido criado e distribuído para empresários que já estavam cadastrados como MEI, a função conativa da linguagem permanece fortemente presente no material e configura-se como a principal função de linguagem da peça, uma vez que o texto busca reforçar a importância da formalização e os direitos adquiridos pelo público. Frases como "Agora é só se formalizar", "É segurança para você”, "Faça como mais de 3 milhões de MEIs e ganhe seus direitos!" e "ser MEI é muito bom” demonstram tal objetivo nessa peça de comunicação. A função referencial também está presente no material, em especial nos textos apresentados em tópicos, assim como a função poética, denotada principalmente na disposição de algumas palavras no leiaute, suas cores e formas: "atenção", “dica” etc.

A representação social do microempreendedor individual apoia-se em representações afins ao conceito, e a objetivação acontece por meio das ilustrações de algumas das atividades permitidas pela legislação: pipoqueiro, sacoleira, borracheiro, joalheiro, artesão, cabeleireiro, manicure, sapateiro e costureira. A ancoragem, por sua vez, traz duas classificações: quem “trabalha por conta própria" e também "todo mundo que rala o dia inteiro". Mais uma vez, o conceito de microempreendedor individual só pode ser comunicado por meio da interação entre texto e imagem. Apesar de ser possível reconhecer nas ilustrações as atividades desempenhadas, como a de pipoqueiro ou a de sacoleira, não é possível compreender, apenas pelas imagens, que aqueles empreendedores são formalizados como MEI.

O processo de identificação do público com o conceito de microempreendedor individual é facilitado, por um lado, pela delimitação do ramo de negócio exposto no folder. Por outro, pode ser prejudicado pela dificuldade de reconhecimento daqueles empreendedores cujos negócios não são apresentados de forma explícita no material. No entanto, ao exibir tantas categorias em uma só peça de comunicação, o objetivo do Sebrae é deixar subentendido que diversas ocupações podem ser formalizadas como microempreendedor individual. 


\subsubsection{Folder SEI - Lew'LaralTBWA 2013}

Ainda em 2013, a agência Lew'LaralTBWA criou e produziu um folder (figura 29) para divulgar as oficinas do SEI, o Sebrae Empreendedor Individual. A capa do folder traz a imagem da janela de um carrinho de pipocas repleto do alimento. $O$ título da peça é: "Microempreendedor Individual. Quer saber como fazer um pequeno negócio estourar? Os especialistas do Sebrae mostram". A capa traz, ainda, no canto inferior direito, o slogan da entidade, o telefone da central de relacionamento e o endereço do portal do Sebrae na internet, além da logomarca.

Figura 29 - Ano 2013, agência Lew'LaralTBWA, campanha

"Folder SEI". Mídia: folder

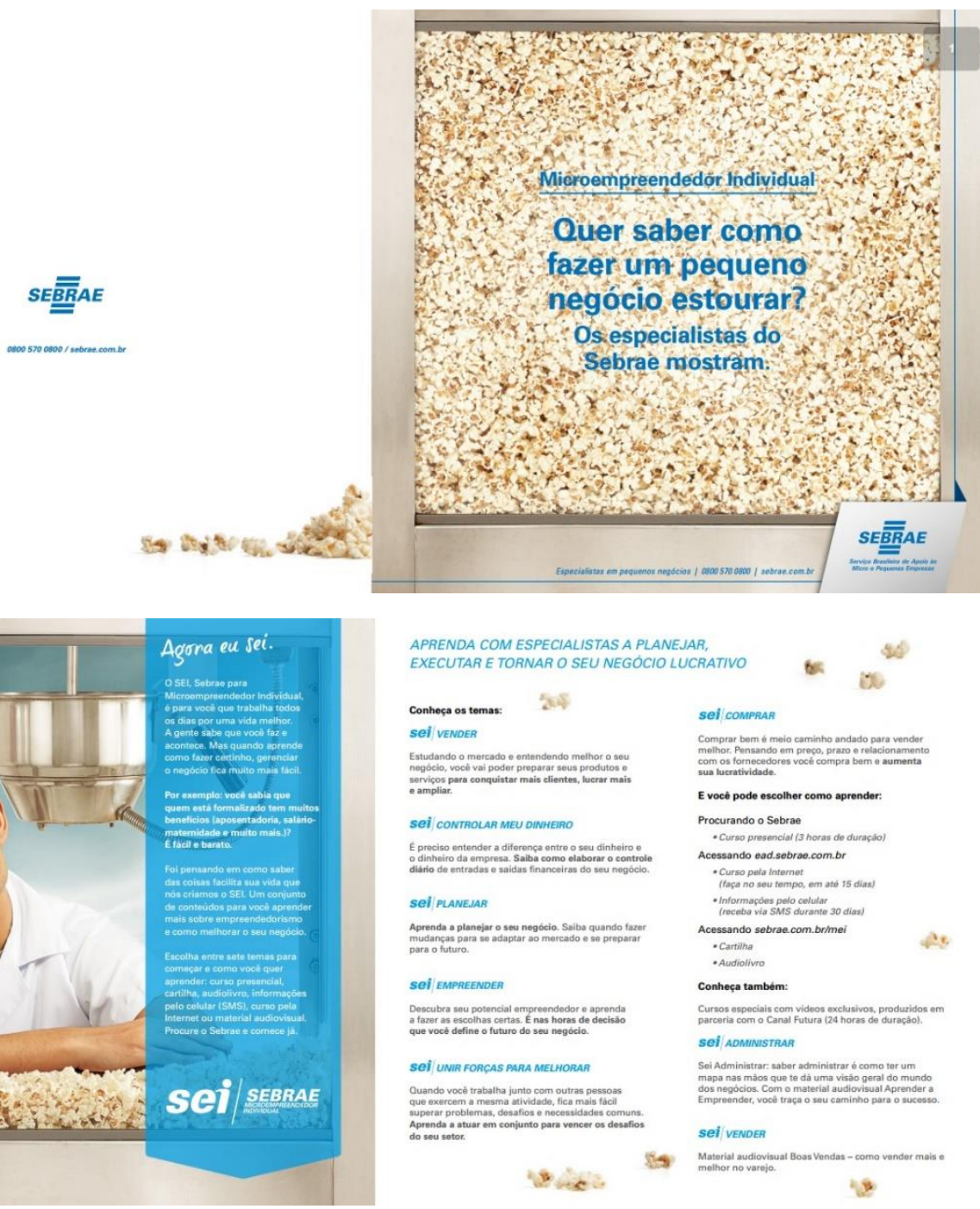

Fonte: material fornecido pela agência Lew’Lara\TBWA 
Internamente, vê-se, à esquerda, a imagem de um pipoqueiro, e, à direita, informações sobre cada um dos cursos. Esta análise terá como foco a página interna esquerda do folder, pois ela apresenta a imagem do pipoqueiro. $\mathrm{O}$ modelo é um homem jovem, pardo, uniformizado com jaleco e touca, que sorri e olha diretamente para a câmera. Está posicionado de braços cruzados e apoiado no carrinho de pipoca, que está à sua frente. O receptor vê o pipoqueiro, portanto, através da janela do carrinho. Ao lado direito da imagem, uma caixa de texto apresenta o SEI: "Agora eu sei. O SEI, Sebrae para Microempreendedor Individual, é para você que trabalha todos os dias por uma vida melhor. A gente sabe que você faz e acontece. Mas quando aprende como fazer certinho, gerenciar o negócio fica muito mais fácil. Por exemplo: você sabia que quem está formalizado tem muitos benefícios (aposentadoria, salário maternidade e muito mais)? É fácil e barato. Foi pensando em como saber das coisas facilita sua vida que nós criamos o SEI. Um conjunto de conteúdos para você aprender mais sobre empreendedorismo e como melhorar o seu negócio. Escolha entre sete temas para começar e como você quer aprender: curso presencial, cartilha, áudiolivro, informações pelo celular (SMS), curso pela internet ou material audiovisual. Procure o Sebrae e comece já". Abaixo, a logomarca do produto.

A mensagem publicitária do folder é instrumental, uma vez que expõe uma necessidade do receptor e indica que, com os cursos do SEI, essa necessidade será satisfeita. Essa estratégia pode ser facilmente percebida na frase: "um conjunto de conteúdos para você aprender mais sobre empreendedorismo e como melhorar o seu negócio". A imagem do pipoqueiro, por sua vez, é explicativa, pois objetiva passar a ideia de que o modelo é um microempreendedor individual.

O material apresenta claramente predominância da função conativa da linguagem, clássica da linguagem publicitária. O texto é totalmente voltado ao destinatário da mensagem, o emissor utiliza bastante a $2^{\mathrm{a}}$ pessoa verbal e o imperativo em frases como "Procure o Sebrae e comece já". O modelo olha diretamente para a câmera, posando, e a paleta de cores do folder remete à cor da marca do Sebrae: azul. É possível, ainda, identificar outras funções da linguagem na peça: a função emotiva, pelo uso da $1^{\text {a }}$ pessoa no título "Agora eu sei” e a função referencial, pela argumentação denotativa que expõe os benefícios dos cursos.

Ao analisar a representação social do MEI nesta peça, percebe-se a mesma necessidade de diálogo entre texto e imagem identificada nas outras análises, uma vez que o conceito de microempreendedor individual não consegue ser comunicado apenas pela foto, ou seja, pela objetivação. Ao analisar a imagem do pipoqueiro, é possível identificá-lo como tal pelos elementos que compõem o quadro: o carrinho de pipoca, a pipoca propriamente dita e o uniforme. No entanto, não há nada que indique que seu negócio é formalizado e que ele é, 
portanto, um MEI. Este significado é conferido pelo texto, que trata do conceito: "você que trabalha todos os dias por uma vida melhor". Resta ao receptor apenas conectar a imagem ao texto e compreender que aquele pipoqueiro retratado é um microempreendedor individual que desfruta de todos os benefícios da formalização, sendo um deles os cursos oferecidos pelo

Sebrae. É interessante notar que o emissor da mensagem utiliza, como estratégia de comunicação, a figura do pipoqueiro para representar visualmente o MEI, mas o texto não menciona, em nenhum momento, esse grupo específico da figura jurídica.

Ao deflagrar o processo de identificação no receptor, a imagem do pipoqueiro pode facilitar ou dificultar todo o processo, assim como acontece com o folder MEI Card, analisado anteriormente. Se o receptor for, de fato, um pipoqueiro, a identidade padrão ativada será a identidade de dono do negócio. Porém, se o receptor da mensagem for um empreendedor atuante em outro ramo de negócio, a identidade padrão de empresário pode não ser ativada pela imagem do pipoqueiro. Mais uma vez, o diálogo entre imagem e texto se apresenta como elemento fundamental para o sucesso da comunicação.

\subsubsection{Sebrae Apresenta - Giacometti 2014}

A última campanha a ser analisada nesta investigação foi criada e veiculada em 2014, pela agência Giacometti. "Sebrae apresenta” traz três histórias de vida de empreendedores, em formato de filme cinematográfico. Um desses empreendedores, Dora, é MEI. Serão analisados, portanto, o anúncio de revista e o filme publicitário que retratam sua história. 
Figura 30 - Ano 2014, agência Giacometti, campanha "Sebrae Apresenta”. Mídia: revista

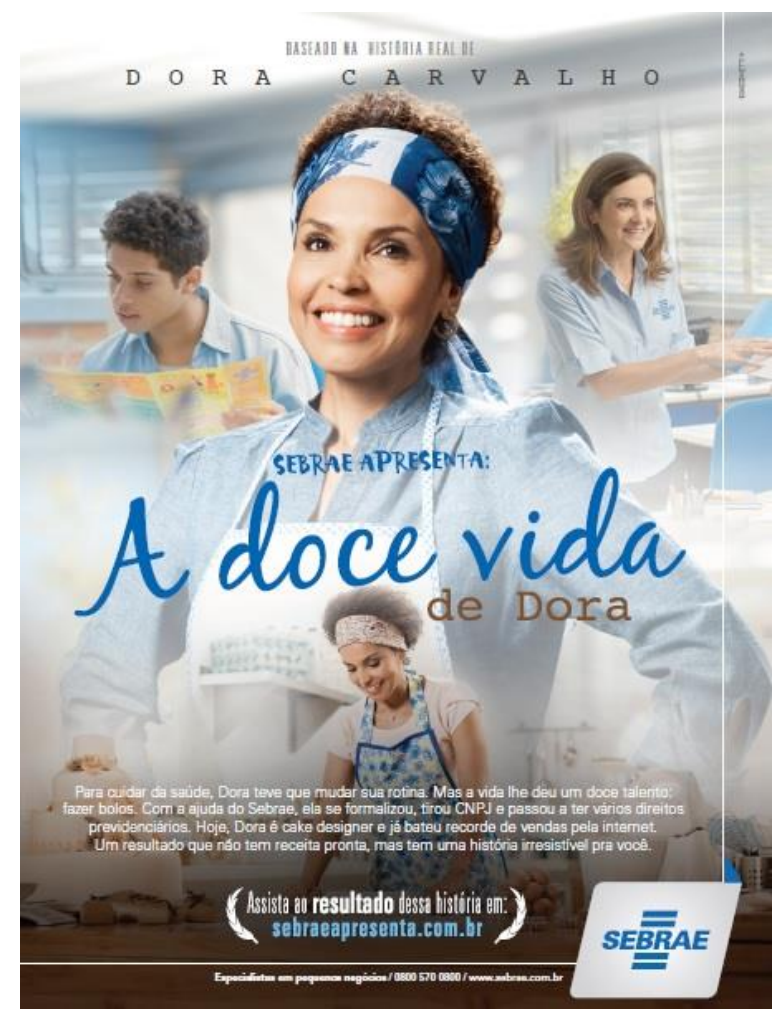

Fonte: material fornecido pela agência Giacometti

O anúncio de revista em formato página simples (figura 30) é inspirado em cartazes de filmes. Na parte superior, vê-se o texto "Baseado na história real de Dora Carvalho". Logo abaixo, ocupando o centro do anúncio, a imagem da personagem Dora é apresentada: uma mulher parda, com cerca de 40 anos, olha para o horizonte e sorri. Veste blusa azul de mangas compridas, avental e lenço branco e azul na cabeça. Atrás da imagem há cenas do "filme", à esquerda, um rapaz vestindo blusa social lê um folder do Sebrae e, à direita, uma funcionária da entidade interage com alguém que não é possível visualizar devido ao corte da imagem. Ela veste blusa social azul com a logomarca do Sebrae. O título da peça, centralizado, nas cores azul e ocre, traz a mensagem: "Sebrae apresenta: A doce vida de Dora". Logo abaixo do título, mais uma imagem de Dora. Dessa vez, trabalhando no que parece ser uma bancada de cozinha. Ela sorri e olha para baixo. Veste blusa rosa de mangas curtas, avental azul e branco e faixa no cabelo, no mesmo tom de sua roupa. Abaixo, o texto do anúncio: "Para cuidar da saúde, Dora teve que mudar sua rotina. Mas a vida lhe deu um doce talento: fazer bolos. Com a ajuda do Sebrae, ela se formalizou, tirou CNPJ e passou a ter vários direitos previdenciários. Hoje, Dora é cake designer e já bateu recorde de vendas pela internet. Um resultado que não tem receita pronta, mas tem uma história irresistível pra você. Assista ao resultado dessa história em: 
sebraeapresenta.com.br". A peça é finalizada com a logomarca da entidade, o slogan, o telefone da central de relacionamento com o cliente e o endereço do site do Sebrae.

A mensagem do anúncio é testemunhal, pois traz a história real de uma microempreendedora individual e a apresenta ao público-alvo da campanha. As imagens presentes no anúncio são explicativas, uma vez que ilustram Dora e seu ofício como MEI. A principal função da linguagem identificada é a referencial, já que a peça conta, de maneira resumida, a história de Dora. A forma pela qual a história é apresentada, incluindo aí a disposição das imagens no leiaute, fazendo referência a um cartaz de cinema, caracterizam a função poética. As funções conativa e emotiva também são identificadas no anúncio: a primeira convida o receptor a assistir o filme pela internet, e a segunda apresenta o emissor da mensagem, ou seja, o Sebrae, por meio da imagem da consultora.

A representação social do MEI é ancorada na peça pela atividade profissional de Dora, uma vez que ela é descrita como cake designer. Não há nenhuma referência explícita a sua atuação como microempreendedora individual, apesar de o texto citar a formalização, o CNPJ e a aquisição de direitos previdenciários. A objetivação do conceito acontece por meio das imagens que apresentam Dora: mulher madura, parda, que trabalha uniformizada, vestindo avental e lenço na cabeça.

É interessante notar como a identificação com o público-alvo pretendida pelo anúncio fica prejudicada pela ancoragem do conceito de MEI. Mesmo deixando explícito que Dora tem "um doce talento" e "bate recorde de vendas pela internet", não é possível afirmar que ela é uma microempreendedora individual, e essa lacuna pode provocar ruídos na comunicação. O Sebrae busca a identificação do público-alvo por meio da comparação social. Assim como na campanha de 40 anos, espera-se que Dora desperte o mesmo sentimento no receptor da mensagem que a personagem Claudinéia: o orgulho por pertencer à categoria de microempreendedor individual. Para aqueles que empreendem informalmente, a história de Dora se transforma em incentivo para a formalização. 
Figura 31 - Ano 2014, agência Giacometti, campanha "Sebrae Apresenta". Mídia: filme
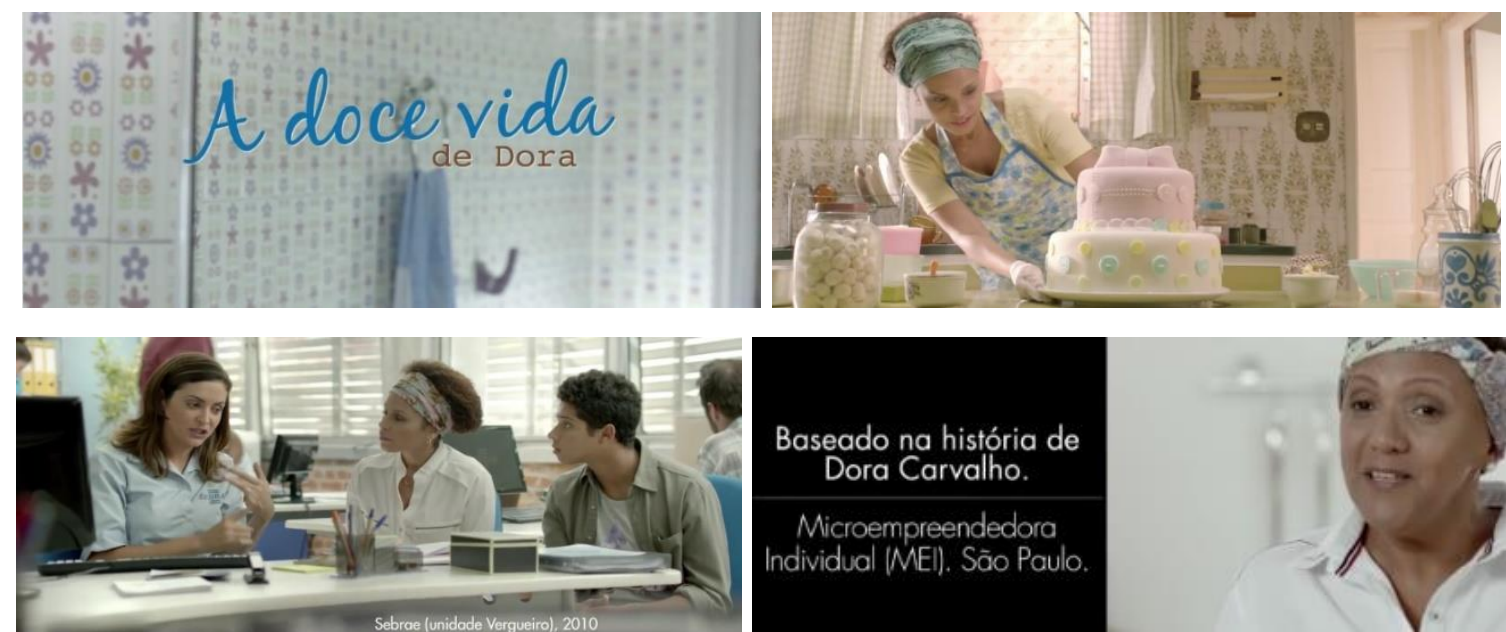

Fonte: material fornecido pela agência Giacometti

O filme da campanha (figura 31), no entanto, consegue apresentar Dora como microempreendedora individual ao ancorar e objetivar o conceito. Com duração de 2 minutos, o filme conta que, após ter um problema de saúde, Dora teve que mudar de vida. Para sustentar a família, passou a vender bolos sob encomenda. O negócio prosperou. Porém, sozinha, Dora não conseguia atender a tantos pedidos, contratar uma ajudante e nem vender para empresas, pois não emitia nota fiscal. Seu filho sugeriu que ela procurasse o Sebrae. Após a formalização como microempreendedora individual, Dora diversificou seus produtos e passou a vender online, ganhando até mesmo um prêmio de empreendedora do ano. Ao final do filme, a verdadeira Dora dá seu depoimento: "Formalizar foi o primeiro passo. Você tem que adquirir novos conhecimentos pra correr atrás dos seus sonhos. E através desses conhecimentos é que eu vou chegar lá”. Depois, entra a locução: “Existem milhões de Doras pelo Brasil. E o resultado dessas histórias é a nossa razão de existir. Sebrae. Especialistas em pequenos negócios”.

A mensagem do filme é claramente testemunhal, enquanto a imagem é explicativa. A principal função da linguagem identificada é a referencial, já que a história de vida de Dora é o grande foco da comunicação. A narrativa também caracteriza a função poética da linguagem, pois há preocupação com a apresentação da história de Dora que, neste caso, é contada como se fosse um filme cinematográfico. Por fim, a função emotiva é identificada pela participação do Sebrae na peça, cujo auxílio no processo de formalização é o ponto de virada na história de Dora.

A representação social, por sua vez, é ancorada no filme por uma única palavra: “empreendedora". E a objetivação, pela imagem de Dora: mulher parda, com cerca de 40 anos, que trabalha uniformizada. Novamente, assim como em todas as peças analisadas, é possível 
compreender que Dora é microempreendedora individual somente pela interação entre texto e imagem, e isso dificulta o processo de identificação do MEI almejado pela comunicação. A identificação, nesta peça, acontece da mesma forma que no cartaz do filme: por meio da comparação social: eleva-se a autoestima do público que já é microempreendedor individual, ao mesmo tempo em que motiva-se a formalização daqueles que trabalham na informalidade.

\subsection{Resultado das análises}

Para concluir a análise das peças publicitárias, apresenta-se, nas tabelas 9 e 10, um resumo das características identificadas em cada uma delas a partir dos critérios que direcionaram o trabalho.

Tabela 9 - Características identificadas nas peças publicitárias do Sebrae direcionadas ao MEI (continua)

\begin{tabular}{|c|c|c|c|c|c|c|}
\hline FIGURA & $\begin{array}{c}\text { TIPO DE } \\
\text { MENSAGEM }\end{array}$ & $\begin{array}{l}\text { TIPO DE } \\
\text { IMAGEM }\end{array}$ & $\begin{array}{c}\text { FUNÇÃO DA } \\
\text { LINGUAGEM } \\
\text { PREDOMINANTE }\end{array}$ & $\begin{array}{c}\text { RAMO DE } \\
\text { NEGÓCIO DO } \\
\text { MEI }\end{array}$ & $\begin{array}{c}\text { IMAGEM É } \\
\text { DESTAQUE } \\
\text { NA PEÇA }\end{array}$ & $\begin{array}{c}\text { COMPLEMEN- } \\
\text { TARIDADE } \\
\text { ENTRE TEXTO E } \\
\text { IMAGEM }\end{array}$ \\
\hline 11 & Instrumental & Explicativa & Conativa & Não identificado & Sim & Necessária \\
\hline 12 & Instrumental & Explicativa & Conativa & Não identificado & Não & Necessária \\
\hline 13 & Instrumental & Explicativa & Conativa & Identificado & Sim & Necessária \\
\hline 14 & Instrumental & Explicativa & Conativa & Identificado & Sim & Necessária \\
\hline 15 & Instrumental & Explicativa & Referencial & Identificado & Sim & Necessária \\
\hline 16 & Instrumental & Explicativa & Conativa & Não identificado & Não & Necessária \\
\hline 17 & Instrumental & Explicativa & Conativa & Identificado & Sim & Necessária \\
\hline 18 & Instrumental & Explicativa & Conativa & Não identificado & Não & Necessária \\
\hline 19 & Instrumental & Explicativa & Conativa & Não identificado & Não & Necessária \\
\hline 20 & Instrumental & Explicativa & Conativa & Não identificado & Sim & Necessária \\
\hline 21 & Testemunhal & Explicativa & Referencial & Identificado & Sim & Necessária \\
\hline 22 & Testemunhal & Explicativa & Referencial & Identificado & Sim & Necessária \\
\hline 23 & Instrumental & Explicativa & Conativa & Não identificado & Não & Necessária \\
\hline 24 & Instrumental & Explicativa & Conativa & Não identificado & Não & Necessária \\
\hline 25 & Testemunhal & Explicativa & Emotiva & Identificado & Sim & Necessária \\
\hline
\end{tabular}


Tabela 9 - Características identificadas nas peças publicitárias do Sebrae direcionadas ao MEI (conclusão)

\begin{tabular}{|c|c|c|c|c|c|c|}
\hline $\mathbf{2 6}$ & Relacional & Explicativa & Emotiva & Identificado & Sim & Necessária \\
\hline $\mathbf{2 7}$ & Testemunhal & Explicativa & Referencial & Identificado & Sim & Necessária \\
\hline $\mathbf{2 8}$ & Instrumental & Explicativa & Conativa & Identificado & Não & Necessária \\
\hline $\mathbf{2 9}$ & Instrumental & Explicativa & Conativa & Identificado & Sim & Necessária \\
\hline $\mathbf{3 0}$ & Testemunhal & Explicativa & Conativa & Identificado & Sim & Necessária \\
\hline $\mathbf{3 1}$ & Testemunhal & Explicativa & Referencial & Identificado & Sim & Necessária \\
\hline
\end{tabular}

Fonte: elaborado pela autora

Tabela 10 - Representação social do MEI nas peças publicitárias do Sebrae (continua)

\begin{tabular}{|c|c|c|c|c|c|}
\hline \multirow{3}{*}{ FIGURA } & \multicolumn{5}{|c|}{ REPRESENTAÇÃO SOCIAL } \\
\hline & \multirow{2}{*}{ ANCORAGEM } & \multicolumn{4}{|c|}{ OBJETIVAÇÃO } \\
\hline & & GÊNERO & IDADE & $\begin{array}{l}\text { APARÊENCIA } \\
\text { FÍSICA }\end{array}$ & OUTRAS CARACTERÍSTICAS \\
\hline 11 & $\begin{array}{c}\text { "trabalha por conta } \\
\text { própria" } \\
\text { "tem um negócio } \\
\text { informal" }\end{array}$ & Homem & 30 anos & Pardo & $\begin{array}{l}\text { Veste camisa social com } \\
\text { logomarca da empresa }\end{array}$ \\
\hline 12 & “empreendedor" & Homem & - & $\begin{array}{c}\text { Não é } \\
\text { possível } \\
\text { identificar } \\
\text { (ilustração) }\end{array}$ & $\begin{array}{c}\text { Veste camisa e calça sociais e } \\
\text { gravata }\end{array}$ \\
\hline 13 & $\begin{array}{c}\text { "quem trabalha por conta } \\
\text { própria" } \\
\text { "ambulante, costureira, } \\
\text { manicure, pedreiro, } \\
\text { pipoqueiro" } \\
\text { "tem um negócio } \\
\text { informal" }\end{array}$ & Homem & $\begin{array}{c}\text { Jovem a } \\
\text { idoso }\end{array}$ & Pardo & Veste chapéu e avental \\
\hline 14 & $\begin{array}{c}\text { "trabalha por conta } \\
\text { própria" }\end{array}$ & Mulher & 40 anos & Branca & $\begin{array}{c}\text { Veste avental e trabalha com } \\
\text { máquina de costura }\end{array}$ \\
\hline
\end{tabular}


Tabela 10 - Representação social do MEI nas peças publicitárias do Sebrae (continua)

\begin{tabular}{|c|c|c|c|c|c|}
\hline 15 & $\begin{array}{l}\text { “empresária da moda" } \\
\text { “dona de firma" } \\
\text { "empreendedora" }\end{array}$ & Mulher & 40 anos & Branca & - \\
\hline 16 & $\begin{array}{c}\text { "trabalha por conta } \\
\text { própria" } \\
\text { "ganha até R\$3 mil por } \\
\text { mês" } \\
\text { "dono do meu negócio" }\end{array}$ & $\begin{array}{l}\text { Homem / } \\
\text { Mulher }\end{array}$ & 30 anos & $\begin{array}{l}\text { Pardo / } \\
\text { Negra }\end{array}$ & $\begin{array}{l}\text { Veste camisa escura e calça } \\
\text { jeans / Veste camisa branca e } \\
\text { saia }\end{array}$ \\
\hline 17 & $\begin{array}{c}\text { “profissão" } \\
\text { "trabalha por conta } \\
\text { própria" } \\
\text { "ganha até R\$3 mil por } \\
\text { mês" } \\
\text { “dono do meu negócio" } \\
\text { "cabeleireiro, massagista, } \\
\text { manicure, podólogo, } \\
\text { maquiador, comerciante } \\
\text { de cosméticos" }\end{array}$ & Mulher & 30 anos & Negra & $\begin{array}{c}\text { Veste avental azul e carrega } \\
\text { um secador de cabelos }\end{array}$ \\
\hline 18 & $\begin{array}{c}\text { "trabalha por conta } \\
\text { própria" } \\
\text { "ganha até R\$3 mil por } \\
\text { mês" } \\
\text { "dono do meu negócio" }\end{array}$ & Mulher & 30 anos & Branca & $\begin{array}{l}\text { Veste camiseta branca e } \\
\text { carrega um bebê no colo }\end{array}$ \\
\hline 19 & $\begin{array}{c}\text { "trabalha por conta } \\
\text { própria" } \\
\text { "ganha até R\$3 mil por } \\
\text { mês" } \\
\text { "dono do meu negócio" }\end{array}$ & Mulher & 40 anos & Negra & $\begin{array}{l}\text { Veste camiseta com a frase da } \\
\text { campanha }\end{array}$ \\
\hline 20 & “empreendedor” & Homem & 60 anos & Branco & $\begin{array}{l}\text { Veste camiseta cinza, óculos e } \\
\text { trabalha com um computador }\end{array}$ \\
\hline
\end{tabular}


Tabela 10 - Representação social do MEI nas peças publicitárias do Sebrae (continuação)

\begin{tabular}{|c|c|c|c|c|c|}
\hline 21 & $\begin{array}{c}\text { "brasileiros" } \\
\text { "donos da própria } \\
\text { empresa" } \\
\text { "dono do meu negócio" }\end{array}$ & $\begin{array}{l}\text { Homem / } \\
\text { Mulher }\end{array}$ & $\begin{array}{l}40 \text { anos / } \\
30 \text { anos }\end{array}$ & $\begin{array}{l}\text { Pardo / } \\
\text { Branca }\end{array}$ & $\begin{array}{l}\text { Veste camiseta e calça jeans / } \\
\text { Veste camiseta e saia listrada }\end{array}$ \\
\hline 22 & $\begin{array}{l}\text { "quem trabalha por conta } \\
\text { própria no Brasil" } \\
\text { "cara bacana com as } \\
\text { leis" }\end{array}$ & $\begin{array}{l}\text { Mulher / } \\
\text { Mulher / } \\
\text { Homem }\end{array}$ & $\begin{array}{l}30 \text { anos / } \\
40 \text { anos / } \\
40 \text { anos }\end{array}$ & $\begin{array}{c}\text { Branca / } \\
\text { Branca / } \\
\text { Pardo }\end{array}$ & $\begin{array}{l}\text { Veste uniforme de trabalho / } \\
\text { Veste roupa estampada / Veste } \\
\text { camisa social azul }\end{array}$ \\
\hline 23 & $\begin{array}{c}\text { "trabalha por conta } \\
\text { própria" }\end{array}$ & Homem & 40 anos & $\begin{array}{c}\text { Não é } \\
\text { possível } \\
\text { identificar } \\
\text { (ilustração) }\end{array}$ & Veste camisa e calça sociais \\
\hline 24 & $\begin{array}{c}\text { "trabalha por conta } \\
\text { própria" }\end{array}$ & Homem & 30 anos & $\begin{array}{c}\text { Não é } \\
\text { possível } \\
\text { identificar } \\
\text { (ilustração) }\end{array}$ & Veste camisa e calça sociais \\
\hline 25 & $\begin{array}{c}\text { "trabalha por conta } \\
\text { própria" }\end{array}$ & Mulher & 40 anos & Negra & $\begin{array}{l}\text { Veste uniforme de chef de } \\
\text { cozinha }\end{array}$ \\
\hline 26 & $\begin{array}{l}\text { “empreendedor" } \\
\text { "brasileiro" } \\
\text { "pessoa rara" } \\
\text { "nada contra a } \\
\text { correnteza" } \\
\text { "segue em frente" } \\
\text { "não é louco" }\end{array}$ & $\begin{array}{l}\text { Homem / } \\
\text { Mulher / } \\
\text { Homem / } \\
\text { Homem / } \\
\text { Mulher }\end{array}$ & $\begin{array}{l}30 \text { anos / } \\
40 \text { anos / } \\
50 \text { anos / } \\
40 \text { anos / } \\
30 \text { anos }\end{array}$ & $\begin{array}{l}\text { Pardo / } \\
\text { Parda / } \\
\text { Pardo / } \\
\text { Pardo / } \\
\text { Branca }\end{array}$ & $\begin{array}{l}\text { Todos vestem camisa estilo } \\
\text { polo, enquanto o protagonista } \\
\text { aparece também com chapéu e } \\
\text { avental em seu negócio }\end{array}$ \\
\hline 27 & "empreendedora" & Mulher & 40 anos & Negra & $\begin{array}{l}\text { Veste uniforme de trabalho } \\
\text { (chapéu, luvas e avental) }\end{array}$ \\
\hline 28 & $\begin{array}{l}\text { "trabalha por conta } \\
\text { própria" } \\
\text { "todo mundo que rala o } \\
\text { dia inteiro" }\end{array}$ & $\begin{array}{l}6 \text { homens } \\
\qquad / 3 \\
\text { mulheres }\end{array}$ & - & $\begin{array}{c}\text { Não é } \\
\text { possível } \\
\text { identificar } \\
\text { (ilustração) }\end{array}$ & $\begin{array}{c}\text { Caracterizados pelas } \\
\text { atividades (pipoqueiro, } \\
\text { sacoleira, borracheiro, } \\
\text { joalheiro, artesão, cabeleireiro, } \\
\text { manicure, sapateiro e } \\
\text { costureira) }\end{array}$ \\
\hline
\end{tabular}


Tabela 10 - Representação social do MEI nas peças publicitárias do Sebrae (conclusão)

\begin{tabular}{|c|c|c|c|c|c|}
\hline 29 & $\begin{array}{c}\text { "trabalha todos os dias } \\
\text { por uma vida melhor" }\end{array}$ & Homem & 30 anos & Pardo & $\begin{array}{c}\text { Caracterizado como } \\
\text { pipoqueiro, com chapéu e } \\
\text { jaleco }\end{array}$ \\
\hline $\mathbf{3 0}$ & $\begin{array}{c}\text { "cake designer" } \\
\mathbf{3 1}\end{array}$ & Mulher & 40 anos & Parda & $\begin{array}{r}\text { Trabalha uniformizada com } \\
\text { lenço e avental }\end{array}$ \\
\hline
\end{tabular}

Fonte: elaborado pela autora

A representação social do microempreendedor individual é um fenômeno recente e por isso há dificuldade na objetivação do conceito. Além do mais, a categoria abarca inúmeras ocupações, o que também dificulta a busca por imagens representativas. Isso é refletido na ausência de encadeamento entre as imagens dos anúncios, uma vez que não há nenhum elemento presente em elas que as identifique como pertencentes à categoria dos MEI. Em outras palavras, não se percebe uma caracterização visual específica para o microempreendedor individual.

Outra possibilidade a ser considerada para a ausência de caracterização visual específica do microempreendedor individual recai sobre os processos de produção da mensagem publicitária. É possível que tanto o Sebrae quanto as agências de publicidade não tenham conseguido reunir informações suficientes sobre esse público para construir uma representação mais direta do conceito, afetando diversas fases da criação, como o planejamento de campanha e a busca por imagens representativas.

Diante dessa dificuldade, uma maneira de tentar concretizar o conceito para que ele seja representado de forma tangível nas peças é representar uma das categorias permitidas pela legislação. Mesmo nesses casos, não é possível fugir da complementaridade entre texto e imagem, na qual o texto é o elemento da peça que indica que o indivíduo no anúncio é um microempreendedor individual. $\mathrm{O}$ texto auxilia, inclusive, os anúncios que utilizam como modelos verdadeiros MEI, pois mesmo nesses casos é preciso ler o texto para compreender que Ivonete é manicure, José é varejista de roupas, Claudinéia é fabricante de trufas e doces e Dora é cake designer. Assim, não é possível dissociar a imagem utilizada para representar o microempreendedor individual do texto da peça publicitária, uma vez que a figura não consegue comunicar o conceito de forma clara e completa. 
De maneira geral, a comunicação do Sebrae para o microempreendedor individual pode ser descrita como instrumental, com imagens explicativas e predominância da função conativa da linguagem. A imagem no MEI no leiaute é normalmente apresentada em destaque e a complementaridade entre texto e imagem é necessária para a construção e comunicação do conceito (tabela 11). É interessante notar que, mesmo sendo a função conativa a principal função de linguagem identificada nas peças, todas as imagens do corpus foram caracterizadas como explicativas, o que evidenciaria a função referencial. No contexto analisado, no entanto, a utilização de imagens explicativas é interpretada como um recurso do Sebrae para auxiliar o processo persuasivo, além de apresentar a nova figura jurídica do MEI ao público daquela comunicação.

Tabela 11 - Principais características das peças publicitárias do Sebrae direcionadas ao MEI

\begin{tabular}{|c|c|c|c|c|c|}
\hline $\begin{array}{c}\text { TIPO DE } \\
\text { MENSAGEM }\end{array}$ & $\begin{array}{l}\text { TIPO DE } \\
\text { IMAGEM }\end{array}$ & $\begin{array}{c}\text { FUNÇÃO DA } \\
\text { LINGUAGEM } \\
\text { PREDOMINANTE }\end{array}$ & $\begin{array}{c}\text { RAMO DE } \\
\text { NEGÓCIO DO MEI }\end{array}$ & $\begin{array}{c}\text { IMAGEM É } \\
\text { DESTAQUE } \\
\text { NA PEÇA? }\end{array}$ & $\begin{array}{l}\text { COMPLEMEN- } \\
\text { TARIDADE } \\
\text { ENTRE TEXTO E } \\
\text { IMAGEM }\end{array}$ \\
\hline Instrumental & Explicativa & Conativa & Identificado & Sim & Necessária \\
\hline
\end{tabular}

Fonte: elaborado pela autora

A representação social, por sua vez, ancora-se na ideia de que o MEI é quem "trabalha por conta própria" e está objetivada como uma figura masculina, parda, que trabalha uniformizada, normalmente vestindo chapéu e avental (tabela 12). É interessante notar que a quantidade de representações do MEI por pessoas pardas é quase a mesma daquelas de pessoas brancas. Enquanto há 9 imagens de pessoas consideradas pardas nos anúncios, 8 são de pessoas brancas. Indivíduos de pele escura aparecem em 5 das peças analisadas. Essa diversidade pode caracterizar, mais uma vez, a dificuldade de objetivação do conceito.

Tabela 12 - A representação social do MEI na publicidade do Sebrae

\begin{tabular}{|c|c|}
\hline \multicolumn{2}{|c|}{ REPRESENTAÇÃO SOCIAL } \\
\hline \hline ANCORAGEM & OBJETIVAÇÃo \\
\hline \hline "trabalha por conta própria" & Homem, 40 anos, pardo, veste uniforme \\
\hline
\end{tabular}

Fonte: elaborado pela autora 
O principal objetivo das peças analisadas é persuadir o empreendedor a formalizar o seu negócio. A compreensão correta da mensagem será possível somente se o receptor identificar o indivíduo representado como MEI e entender que, ao sair da informalidade, ele também poderá ser um microempreendedor individual. Em outras palavras, a representação procura criar identificação com o empreendedor que trabalha informalmente para que ele veja a si mesmo, num futuro próximo, com sua empresa formalizada, desfrutando de todos os benefícios dessa formalização. Os anúncios objetivam que "o espectador realize uma comparação entre ele e as representações de si mesmo em mídias, em imagens icônicas ou mentais" (FORMIGA SOBRINHO; 2004, p. 27).

Não se trata de exigir o impossível, ou seja, que todo e qualquer MEI se veja, como num espelho, na fotografia do anúncio. A imagem deve apresentar "características que permitam ao espectador a realização de associações entre a personagem da ficção e as pessoas - ou a ideia que possuem dessas pessoas - tidas como reais" (Id., p. 10 e 11). Para o caso das campanhas analisadas, a complementaridade entre texto e imagem aparenta ser crucial para o sucesso da comunicação. Como defende Joly (2012, p. 70), "não existe receita milagrosa para arregimentar o consumidor, cujos comportamentos ainda dependem dos acasos do empirismo".

\section{O ANTES E O DEPOIS DA REPRESENTAÇÃO DO MICROEMPREENDEDOR INDIVIDUAL}

A análise das mensagens publicitárias e seus elementos permite compreender apenas parcialmente os fenômenos comunicacionais, incluindo o objeto de estudo aqui proposto. Além dos próprios agentes do processo, ou seja, o emissor e o receptor, o contexto de produção e apropriação das mensagens é igualmente importante na construção de significados. Como bem justifica Thompson (1995, p. 405 e 406),

\footnotetext{
é importante dar-se conta que o que nós tomamos como atividades de recepção - ler livros, assistir televisão, ouvir música - são ações complexas e altamente qualificadas, que envolvem o emprego de uma grande porção de conhecimento adquirido e que se sobrepõem, de maneiras complexas, a outras atividades, na organização rotineira da vida quotidiana. [...] Se analisarmos as atividades de recepção nessa perspectiva, podemos constatar quão enganoso seria tentar tirar as consequências das mensagens comunicativas apenas das mensagens (o que chamei de falácia do internalismo), pois tais inferências não levariam em consideração as maneiras concretas como essas mensagens são escutadas (ou ignoradas) pelas pessoas que as recebem.
}

Assim, para aprofundar a discussão e compreender o fenômeno comunicacional em sua totalidade, tanto na esfera de produção da mensagem quanto de sua recepção, parte-se para a 
terceira fase da hermenêutica de profundidade. Chamada por Thompson de interpretação ou reinterpretação, ela acontece nesta investigação por meio da realização de entrevistas em profundidade e grupos focais.

A pesquisa qualitativa proporciona a construção de espaços criadores de sentidos subjetivos, com grande pluralidade de informações, gerando "material diferenciado, contraditório e carregado de emotividade [...] cuja construção será sempre uma interpretação do pesquisador" (GONZÁLEZ REY, 2005, p. 111). As chamadas conversações são tidas pela sociologia e antropologia como grandes trunfos na pesquisa de fenômenos sociais (Id., p. 2005, p. 50), e acredita-se que também sirvam para a comunicação. Assim, a realização de entrevistas e grupos focais é pertinente ao contexto desta investigação e está alinhada à proposta de interpretação trazida pela terceira fase da hermenêutica de profundidade, referencial metodológico adotado neste trabalho.

\section{1. $O$ antes: a produção da mensagem}

Para investigar especificamente o contexto de produção das mensagens, foram realizadas entrevistas em profundidade com profissionais da Unidade de Marketing e Comunicação do Sebrae (UMC) e das agências de publicidade que atendem à entidade. Não houve grandes preocupações com a quantidade de pessoas entrevistadas, uma vez que o universo de profissionais envolvidos diretamente com o microempreendedor individual, tanto no Sebrae, quanto nas agências, era relativamente pequeno. Além disso, o objetivo da pesquisa qualitativa, conforme afirma González Rey (2005, p. 113), "está na construção de modelos sobre o problema estudado e não na caracterização de populações”.

Como apresentado anteriormente, até março de 2015 a equipe da UMC era composta por um gerente, um gerente adjunto e 23 funcionários. Desses, foram entrevistados três profissionais que trabalham especificamente com publicidade externa, um funcionário que trabalha com ações de marketing, o gerente e o gerente adjunto da área. O roteiro utilizado para as entrevistas é apresentado a seguir e serviu como guia para o levantamento das informações necessárias à investigação. As perguntas elaboradas eram flexíveis e foram modificadas e adaptadas pela pesquisadora no decorrer das entrevistas, de acordo com as informações recebidas dos entrevistados.

1) Informações de perfil: nome, idade, cargo, tempo de trabalho no Sebrae.

2) Há quanto tempo trabalha especificamente na área de marketing e comunicação? 
3) É formado na área?

4) Como o briefing é elaborado e repassado às agências?

5) Existem critérios de distribuição dos briefings entre as agências?

6) Quais informações sobre o microempreendedor individual estão disponíveis ao Sebrae?

7) Como é construída a imagem do MEI para figurar nas campanhas?

8) Em sua opinião, existe dificuldade na representação visual do microempreendedor individual?

9) Como ocorre o processo de aprovação das propostas apresentadas pelas agências?

10) São realizadas pesquisas de recall das campanhas veiculadas para o MEI?

Além dos funcionários da área de comunicação, foram entrevistados quatro profissionais que atuam diretamente com o microempreendedor individual em outras frentes: políticas públicas, atendimento e capacitação empresarial. Ao todo, foram ouvidos quatro homens e seis mulheres. As entrevistas aconteceram entre os dias 31 de março e 19 de maio de 2015, na sede do Sebrae Nacional e na Junta Comercial do Distrito Federal, onde funciona um posto de atendimento do Sebrae. Cada uma das 10 entrevistas realizadas teve duração média de 35 minutos, totalizando aproximadamente 6 horas de áudio gravado. A degravação do material foi executada pela empresa Brasília Degravações, contratada com recursos próprios da pesquisadora.

A coleta de dados nas agências de publicidade, por sua vez, foi realizada por meio de entrevistas em profundidade e entrevistas coletivas, de acordo com a disponibilidade dos entrevistados. Foram ouvidos 9 profissionais de criação, atendimento, mídia e planejamento que trabalharam em campanhas direcionadas ao microempreendedor individual, inclusive três dos quais já não trabalhavam mais nas empresas. As entrevistas aconteceram nos escritórios das agências entre os dias 11 de abril e 14 de maio de 2015, e duraram, em média, uma hora, gerando 4 horas de material de áudio. Esse material também foi degravado pela empresa Brasília Degravações.

É importante destacar que, entre os anos de 2009 e 2014, período analisado pela pesquisa, o Sebrae contava apenas com o atendimento de duas agências: Lew'LaralTBWA e Giacometti. Em junho de 2013, a agência Nova/SB passou a dividir a conta da entidade com as empresas anteriores. No entanto, esse último fornecedor não criou nenhuma campanha específica para o MEI até dezembro de 2014 e, por isso, não foi prevista coleta de dados com os profissionais dessa agência. No entanto, e coincidentemente, um dos profissionais que 
trabalhou com o MEI fazia parte, na época da coleta, da equipe da Nova/SB. Sendo assim, ele foi entrevistado para a investigação.

É apresentado, a seguir, o roteiro utilizado como guia para as entrevistas com esse público:

1) Informações de perfil: nome, idade, cargo, tempo de trabalho na agência.

2) Há quanto tempo trabalha especificamente atendendo às demandas do Sebrae?

3) A agência busca informações sobre o MEI além daquelas fornecidas pelo Sebrae para a criação das campanhas? Se sim, onde e como?

4) Como é construída a imagem do MEI para figurar nas campanhas?

5) A criação de campanhas testemunhais é uma ideia que parte da agência? Em caso positivo, como essa decisão é tomada?

6) Algumas peças publicitárias apresentam ao receptor da mensagem o ramo de atuação do microempreendedor individual, enquanto outras não. Por quê?

7) Em sua opinião, existe dificuldade na representação visual do microempreendedor individual?

8) Como ocorre o processo de aprovação interna das peças, antes de serem apresentadas ao cliente?

A análise do áudio foi realizada com base nos documentos degravados. A interpretação, dessa vez por parte da pesquisadora, foi o elemento condutor da análise. Conforme afirma González Rey (2005, p. 32):

\footnotetext{
o sentido não é algo que aparece diretamente nas respostas das pessoas, nem nas representações que as alimentam, apenas aparece disperso na produção total da pessoa, pelo que necessitamos da interpretação e de nossas construções para produzir inteligibilidade sobre ele.
}

Assim, foram identificados, ao longo das conversas, temas chave relacionados ao microempreendedor individual, incluindo sua representação social, traços de personalidade e estratégias de comunicação para esse público. González Rey denomina tais temas de "zonas de sentido" e ressalta a importância de se levar em consideração cada resposta dada, cada informação apresentada pelos entrevistados, mesmo que a referência seja mencionada apenas uma única vez. O resultado das entrevistas é apresentado a seguir. 


\subsubsection{Quem cria a mensagem}

O profissional do Sebrae que trabalha com o microempreendedor individual, seja na área de comunicação ou na área de atendimento, tem cerca de 40 anos, possui pós-graduação completa, MBA e faz parte do corpo de funcionários da entidade há mais de 10 anos, em média. Alguns deles atuam também como empresários, administrando seus próprios empreendimentos. Todos aqueles que trabalham na área de comunicação são publicitários ou jornalistas. $\mathrm{O}$ funcionário do Sebrae é entusiasta da causa da entidade e engajado no trabalho que desempenha.

Todos os entrevistados demonstraram muita segurança ao falar sobre o público empreendedor e sobre o funcionamento do Sebrae, seus pontos fortes e os gargalos enfrentados pela entidade. As frustrações registradas eram, em todas as ocasiões, ligadas a um sentimento de "querer fazer mais". Houve, inclusive, situações em que o entrevistado solicitou que o gravador fosse desligado. Existe ainda a sensação de que o Sebrae pode ampliar o apoio ao empreendedor e tornar suas soluções de atendimento ainda melhores. O perfil do profissional que trabalha no Sebrae, independentemente de sua área de atuação, pode ser resumido na seguinte frase: "eu quero fazer mais porque amo o que faço e acredito no empreendedorismo".

É preciso atenção, no entanto, para que a experiência gerada pelos anos de Sebrae não prejudique a busca por novos conhecimentos e perspectivas de atuação. Especificamente em relação ao microempreendedor individual, corre-se o risco de manter uma estratégia de comunicação que, em algum momento, não funcionará mais, pois o público mudou. Em alguns depoimentos os entrevistados afirmam que tanto o Sebrae quanto as agências de publicidade já conhecem o público MEI, e que não há novidade em relação aos jobs da Semana do Microempreendedor Individual: "é só falar o que a gente quer falar esse ano na Semana do MEI, de que período que vai ser; como é que vai ser o tom da nossa comunicação e a gente, eles fazem, não tem muito o que [falar]..., na verdade eles não precisam nem tanto desses dados". Há algumas afirmações categóricas e deterministas que podem se transformar em regras ou padrões e prejudicar a comunicação com o público.

Essa questão pode ser percebida também na análise dos anúncios. Das seis campanhas criadas para a Semana do Microempreendedor Individual, duas não possuem imagens do MEI, porém apresentam mesmo leiaute, e outras três fazem uso de imagens já utilizadas em outras campanhas, além de manter o mesmo leiaute, apenas atualizando informações relevantes, como datas. "A gente trabalha muitas vezes com a mesma cara dessa campanha, a gente muda uma coisa ou outra". É preciso cautela ao apostar em estratégias de comunicação que se mantêm ao 
longo dos anos, uma vez que o contexto social se modifica com o tempo, bem como o próprio público-alvo.

Essa reflexão deve ser feita conjuntamente com agências, parceiros e outros fornecedores do Sebrae. O profissional que trabalha nas agências de publicidade licitadas tem perfil semelhante àquele do funcionário do Sebrae, o que pode ser vantajoso ou desfavorável ao contexto de produção da mensagem publicitária. Apesar de diminuir a incidência de conflitos entre o Sebrae e seus fornecedores, perfis divergentes podem dar vazão a novas ideias e perspectivas para a comunicação. Durante o período de entrevistas, foram ouvidos três homens e seis mulheres, todos com formação na área de comunicação e com vasta experiência no mercado. Em média, esses profissionais atendem o Sebrae há 9 anos.

Os entrevistados nas agências compartilham do sentimento do colaborador da entidade ao refletirem sobre o empreendedorismo, o empresário e sobre as possibilidades oferecidas pelo Sebrae para esse público. Ou seja, há uma vontade de "fazer mais" e percebe-se engajamento em relação à causa dos pequenos negócios. Também foram registradas frustrações, principalmente aquelas relacionadas a orçamento e alguns direcionamentos do Sebrae para soluções criativas de comunicação. Essas são questões já conhecidas entre agências e seus clientes, porém bastante delicadas. Apesar de existir uma boa relação entre o Sebrae e seus fornecedores, apontada por ambas as partes durante as entrevistas, é natural que haja disputas e intensa negociação no dia a dia, sempre em busca de uma comunicação mais eficaz. Exemplos de depoimentos sobre essa relação são apresentados a seguir:

\footnotetext{
O Sebrae está a anos luz de $90 \%$ dos clientes que existem em Brasília, mesmo. Assim, o Sebrae é um cliente muito aberto, se a gente explicar e justificar, eles ouvem; existe uma troca [...] a gente percebe, é que o cliente, às vezes, coloca uma viseira, assim, para uma coisa, e não se permite abrir um pouco para outra [...] acho que a percepção de próprio Sebrae é mais caricaturada do que a nossa para alguns públicos.
}

É interessante que, mesmo com uma avaliação crítica a respeito do perfil do público empreendedor, alguns entrevistados assumem uma postura arriscada ao considerar que o retrato do microempreendedor individual está completamente desvendado, que não há mais nada a ser estudado ou compreendido e, ainda mais grave, que esse perfil é definitivo, imutável.

A relação entre cliente e agência no processo de criação de uma campanha publicitária se inicia com um briefing, normalmente um documento onde é oficializada a demanda de comunicação e onde são registrados seus objetivos, direcionamentos e limitações. No Sebrae, os briefings não são caracterizados por documentos físicos. Eles são repassados às agências durante reuniões de trabalho. Essa foi a declaração de grande parte dos entrevistados, tanto 
daqueles que trabalham no Sebrae, quanto dos publicitários das agências. "Como essa ação já é recorrente, ela já acontece todo ano, não existe hoje uma necessidade de a gente sentar e elaborar um briefing formal para agência do que vai fazer", ou ainda "Hoje a gente fala: "Olha, vai ter Semana do Microempreendedor Individual, a gente precisa de fazer um enxoval básico para que os estados possam fazer a divulgação". Enxoval básico, nesse contexto, refere-se a anúncios de revista, jornal, algumas peças para internet e e-mail marketing, materiais comuns à comunicação publicitária realizada pelo governo, da qual o Sebrae busca se dissociar diante do seu público.

As agências mencionaram as reuniões de briefing em todas as entrevistas, em depoimentos como: "é uma reunião, eles chamam a gente, apresentam alguns pontos e aí está passado o briefing" e "geralmente é feita uma reunião". Ao serem indagados sobre a entrega de um documento formal, alguns entrevistados afirmaram que às vezes recebem os direcionamentos para as campanhas por e-mail, e outros afirmaram categoricamente que não existe essa formalidade no Sebrae. Dessa forma, percebe-se que as reuniões de briefing acabaram se transformando numa prática comum no dia a dia da entidade. Porém, elas, assim como os briefings, não são exigidas formalmente pelo Sebrae.

Curiosamente, um funcionário do Sebrae mencionou a existência de um modelo de briefing padrão que é preenchido e repassado às agências. Esse repasse fica a critério do técnico responsável pela demanda:

\footnotetext{
[Existe] um documento. Pode ser por e-mail mesmo, não é? Na verdade, a gente, na maioria das vezes, faz das duas maneiras. Por $e$-mail e por reunião, mas primeiramente a gente passa [o briefing] por reunião. E depois dessa reunião a gente elabora um documento, inclusive que é para deixar registrado para os dois lados que houve a demanda, e o que foi falado dessa demanda, para que a gente não tenha problemas no futuro, não é? [...] Tem técnico que passa somente oralmente. Tem técnico que passa por briefing também.
}

No entanto, ao receber do Sebrae o material de campanha para análise, não havia nenhum documento intitulado briefing, ou mesmo nenhum documento que tivesse as características de um. Além das peças gráficas e filmes, duas campanhas foram entregues com documentos que apresentavam o planejamento estratégico e a linha criativa das peças, trabalho realizado pelas agências de publicidade numa fase posterior do processo de criação.

Esses depoimentos demonstram que não há, no Sebrae, uma maneira determinada e formalizada pela qual são demandados trabalhos de comunicação para as agências de publicidade. Apesar disso, nenhuma das partes ouvidas reivindicou a existência do documento formal. Aparentemente, as reuniões realizadas e o bom relacionamento entre Sebrae e agências 
permite que os trabalhos sejam executados a contento, e encontros para alinhamento foram mencionadas por todos.

Ao tratar especificamente do MEI, um dos primeiros tópicos abordados foi sobre o levantamento de informações a respeito do público. Anualmente, o Sebrae realiza uma pesquisa para traçar o perfil do microempreendedor individual. A pesquisa tem caráter qualitativo e é realizada pela Unidade de Gestão Estratégica (UGE) em parceria com a Unidade de Políticas Públicas (UPP) e a Unidade de Atendimento Individual (UAI). A comunicação do Sebrae não participa da construção da pesquisa, mas auxilia na diagramação e editoração do material após a consolidação dos dados. "Já tem um formato do perfil do Microempreendedor Individual que tem sido feito anualmente. As perguntas que são feitas pela UGE para se fazer a pesquisa são construídas em conjunto com a UPP e a UAI".

O objetivo da pesquisa é traçar um panorama de quem é o microempreendedor individual e disponibilizar essas informações para todo o Sistema Sebrae, para auxiliar na criação e melhoria de produtos e serviços direcionados ao público. A comunicação, obviamente, também se beneficia desses dados, que são também repassados às agências de publicidade. A pesquisa assemelha-se a um censo demográfico, trazendo informações como: "se ele melhorou as vendas com a formalização; quanto tempo ele estava na informalidade; se ele tem dificuldade em contratar um empregado. Enfim, todas essas perguntas que constroem o perfil do microempreendedor individual”.

Ao indagar, durante a coleta de dados, sobre as informações disponíveis a respeito do MEI, todos os entrevistados mencionaram a pesquisa realizada pela UGE. Também foram citadas outras pesquisas, porém mais amplas, mas que, em algum momento, levantaram informações sobre o microempreendedor individual. Em relação a pesquisas de comunicação, a mais citada pelos entrevistados foi a pesquisa de recall, no entanto, de maneiras distintas.

Alguns afirmaram que sempre são feitas pesquisas de recall. Porém, ao serem questionados sobre os resultados de tais pesquisas, percebeu-se que elas são realizadas somente quando as campanhas têm maior investimento financeiro, ou seja, "só campanha grande", "campanhas acima de, acho que um milhão, antigamente a regra era de um milhão", "campanhas de maior porte sempre têm pesquisa de recall para avaliar a eficiência, se a gente chegou lá onde a gente queria". Para as agências, o recall só é feito "quando o Sebrae pede". O Sebrae, por sua vez, admite que gostaria de investir mais em pesquisa: “infelizmente nós não gastamos o quanto nós gostaríamos de gastar em pesquisa. Nós gostaríamos de fazer recall de absolutamente todas as campanhas". 
Quando são abordadas especificamente as campanhas direcionadas ao microempreendedor individual, fica claro que não há pesquisa de recall, uma vez que "nos últimos dois anos, dois ou três anos, a campanha diminuiu, a massa de investimento", "foi uma campanha pequenininha", "pesquisa de recall, não. Nós não fizemos". Além disso, e especificamente referindo-se à Semana do Microempreendedor Individual, as ações são consideradas pontuais e, assim, "a gente não vê necessidade de fazer, o recall na verdade é o próprio atendimento, o próprio atendimento que o estado teve durante a Semana. Então você já tem o recall dessa campanha". Ou seja, a única informação da qual o Sebrae dispõe sobre a efetividade da campanha publicitária para a Semana do MEI é o número de atendimentos realizados naquele período. No entanto, número de atendimentos não é uma medida válida de recall de campanha, uma vez que o principal objetivo dessas pesquisas é avaliar a lembrança da marca do anunciante e da comunicação veiculada por ele. Além disso, a busca pelo atendimento durante a Semana do MEI tem causas diversas: desde o empresário que viu, de fato, o anúncio do Sebrae, até aquele que foi incentivado pela família e amigos a procurar capacitação empresarial. Ou, ainda, o empreendedor que estava passando pelo local do evento e a movimentação de pessoas chamou sua atenção.

Outra questão interessante refere-se à dificuldade de se fazer pesquisa de recall da Semana do Microempreendedor Individual, visto que a estratégia de comunicação do Sebrae Nacional, nos últimos anos, tem sido criar peças publicitárias e enviá-las ao Sebrae nos estados, que compram espaços de mídia de maneira independente, ou seja, sem o investimento direto do Sebrae Nacional. Algumas vezes há repasse de verba ou os estados indicam ao Sebrae Nacional a mídia desejada para divulgar o evento. Conforme explicou um dos entrevistados:

Ficou por conta dos estados, a gente mandava a linha institucional para ele e eles adaptam do jeito que eles quiserem. Então isso também faz com que a gente não tenha como medir o recall, né? Porque a gente não tem o plano de mídia de todos os estados, para poder avaliar.

Durante as entrevistas, foi possível perceber que a ideia de pesquisa em comunicação que permeia o imaginário dos profissionais do Sebrae está fortemente ligada a pesquisas de recall. Outros tipos de levantamento de dados foram mencionados, como pesquisas na internet e entrevistas informais com empresários. No entanto, em se tratando de pesquisas formais, não foram mencionadas, além do recall, outros tipos de investigação para fundamentar a criação das campanhas, incluindo aí a realização de pré-testes. Um único entrevistado mencionou uma 
investigação específica de comunicação: a pesquisa de imagem do Sebrae: "na pesquisa de imagem do Sebrae a gente tem um pouquinho de informação sobre o MEI”.

As agências de publicidade, por sua vez, se mostraram mais proativas em relação a pesquisas de comunicação, em especial sobre o microempreendedor individual. Todas afirmaram pesquisar constantemente sobre o público, em especial durante o processo de criação publicitária: "criação sempre passa pela parte da pesquisa", "não existe criação sem pesquisa", "o processo de criação é um processo de pesquisa constante, não tem como não ser feito dessa forma". Para esses profissionais, é preciso "ver o que a concorrência está fazendo [...] como o mercado pensa sobre esse assunto [...] o que a mídia está falando sobre esse assunto".

Ao serem questionados sobre o tipo de pesquisa realizada, vários modelos foram descritos. Assim como o Sebrae, os profissionais das agências mencionaram tanto o levantamento de informações de maneira informal, sem referências teórico-metodológicas específicas, quanto pesquisas estruturadas. Pesquisas de mídia, pesquisas sobre a percepção de marca do Sebrae e sobre produtos foram citadas, além de buscas na internet e entrevistas com empresários.

Eu acho que tudo é válido. Mas gente tem um computador na nossa frente. A primeira coisa que a gente faz é ir à internet, agora, se no caso do MEI eu tenho algum amigo que trabalha com isso, como normalmente a gente tem pessoas que estão tentando abrir empresas, então também, tudo é conteúdo nessa hora, assim.

Independentemente da forma como as pesquisas são realizadas, tanto o Sebrae quanto as agências acreditam na importância do conhecimento sobre o público-alvo para promover uma comunicação eficiente e reconhecem a importância da busca por informações nas diversas etapas do processo de criação da mensagem publicitária: desde o atendimento, passando pelo planejamento, a criação e a mídia.

Por fim, é interessante notar que, durante as entrevistas, ao serem mencionadas ações de comunicação direcionadas ao MEI sem que a pesquisadora citasse uma campanha específica, todos os entrevistados, tanto Sebrae, quanto agências, referiram-se imediatamente às ações de divulgação da Semana do Microempreendedor Individual. Apenas um profissional entrevistado mencionou espontaneamente a campanha "Ei. Tá na hora de se formalizar". 


\subsubsection{A representação social do MEI}

Para construir a representação social do MEI no âmbito da produção da mensagem publicitária buscou-se, ao longo de todas as entrevistas realizadas, os termos, expressões e opiniões que caracterizassem a ancoragem e a objetivação desse conceito. Além disso, foi possível identificar representações afins àquela do microempreendedor individual, bem como a representação social contrária à de MEI.

\subsubsection{A ancoragem}

Para o público entrevistado, ou seja, os profissionais do Sebrae e das agências de publicidade, a ancoragem do conceito de microempreendedor individual é "quem trabalha por conta própria". Essa foi a descrição mais comum do MEI durante a coleta de dados. O microempreendedor também é descrito como "ambulante", o trabalhador "autônomo", aquele que trabalha "na rua" e, de forma menos usual, o "informal" e aquele "cara que faz bico". Apenas um entrevistado referiu-se ao microempreendedor individual como um "empresário", o que é notável, visto que um dos principais objetivos de comunicação do Sebrae é justamente mostrar ao MEI que ele é, sim, um empresário, mesmo que sua empresa seja pequena.

\subsubsection{A objetivação}

A objetivação do conceito reflete-se na descrição física do MEI identificada durante as entrevistas. O público descreve o microempreendedor individual como um homem, negro, com cerca de 40 anos, que veste camisa branca e calça jeans. Essa objetivação, assim como a ancoragem, é diferente daquela encontrada nos anúncios publicitários do Sebrae, onde o MEI figura como homem, pardo, com 40 anos e que trabalha uniformizado. No entanto, no que diz respeito ao gênero, a objetivação coincide com aquela dos anúncios, já que $51 \%$ dos personagens são homens, e também com os números oficiais sobre o MEI, segundo os quais $53 \%$ dos empresários são do sexo masculino.

É preciso discorrer sobre alguns aspectos da objetivação do microempreendedor individual surgidos nas entrevistas: o primeiro deles é o equilíbrio entre gêneros. Apesar de a maioria dos entrevistados descreverem o MEI como um homem, o número de definições que materializam o público como mulher foi também expressivo. Mesmo a maioria dos entrevistados sendo do sexo feminino, a associação imediata do conceito com o gênero 
masculino pode ser explicada pelo próprio caráter masculino do nome MEI. Entretanto, dois entrevistados objetivaram o microempreendedor individual como "um casal", e "não necessariamente um homem ou uma mulher".

O segundo aspecto trouxe à tona a questão da cor da pele. O MEI foi descrito pela maior parte dos entrevistados como "negro" ou "negra", e um profissional afirmou imaginar o público como um "negro com cabelão black-power". O pardo, segunda cor de pele mais mencionada, foi referido pelos entrevistados como "mais moreno, não necessariamente negro, mas moreno", "menina mais moreninha". É interessante notar que todos os depoimentos adjetivaram o indivíduo pardo utilizando a palavra moreno e suas variações. Essa é uma característica vista em pesquisas de ampla abrangência realizadas pelo IBGE, como aquela conduzida por Rafael Osorio (Apud PETRUCCELLI; SABOIA, 2013, p. 91), onde no " sistema classificatório de "cor ou raça" do IBGE [...] os pardos se declararam preferencialmente como morenos".

Além disso, nenhum dos entrevistados descreveu o público como branco, amarelo ou indígena, outras categorias dentro da classificação do IBGE. É compreensível que amarelos e indígenas não façam parte da representação social do MEI para o público entrevistado, já que essas características figuram em menor número na população brasileira. No entanto, é curioso que ninguém tenha descrito o microempreendedor individual como um sujeito de cor branca, visto que "em 2010, o Brasil contava com uma população de 191 milhões de habitantes, dos quais 91 milhões se classificaram como brancos (47,7\%)” (IBGE, 2011, p. 75). É possível que essa classificação tenha sido deixada de lado porque esteja limitada, no imaginário dos entrevistados, a "pele clara, olhos claros, cabelos lisos, lábios e nariz finos", o típico "padrão de beleza para toda a espécie humana", como afirmou Carvalho (Apud PETRUCCELLI; SABOIA, 2013, p. 19).

Ao discorrer sobre a idade do MEI, os entrevistados utilizaram expressões como: "pessoa de meia idade. Mais para 40 do que para 30", "não vem um jovem na minha cabeça", "na faixa de uns trinta anos", "um cara mais velho mesmo, entendeu, uns 35 para 40", "idoso", "de média idade, entre 40 e 50 anos" e "eu imagino um pouquinho mais velha, assim uns quarenta e poucos anos". A média de idade descrita coincidiu com aquela dos anúncios e também está alinhada com a pesquisa sobre o perfil do MEI. É possível que os dados da pesquisa tenham influenciado a percepção dos entrevistados. Não apenas aqueles que apontam especificamente a idade do público, mas também os que afirmam, por exemplo, que o microempreendedor individual trabalhou em média 10 anos na informalidade antes de regularizar seu negócio, referindo-se a maturidade e experiência adquiridos após tantos anos a frente de um negócio. 
Por fim, apenas um entrevistado, homem, mencionou a vestimenta do microempreendedor individual, e essa descrição não foi a mesma percebida nos anúncios analisados. Enquanto as peças de comunicação retratam o MEI com uniforme de trabalho, normalmente um avental, o imaginário do entrevistado apresenta o público vestindo camiseta branca e calça jeans. Assim, a tabela 13 resume a representação social do microempreendedor individual na esfera de produção da mensagem, ou seja, no âmbito do Sebrae e das agências publicitárias, responsáveis pela criação e veiculação de publicidade para o público:

Tabela 13 - A representação social do MEI na esfera da produção da mensagem

\begin{tabular}{|c|c|}
\hline \multicolumn{2}{|c|}{ REPRESENTAÇÃO SOCIAL } \\
\hline \hline ANCORAGEM & OBJETIVAÇÃo \\
\hline \hline "trabalha por conta própria" & Homem, 40 anos, negro, veste calça jeans e camiseta \\
\hline
\end{tabular}

Fonte: elaborado pela autora

\subsubsection{As representações afins}

Durante as entrevistas, foram citados, por 93 vezes, tipos de negócio que caracterizam o MEI. O microempreendedor individual mais citado foi o pipoqueiro (12 vezes), seguido por manicure (10 vezes), cabeleireiro, costureira e vendedor de cachorro-quente (cada um mencionado 5 vezes). O feirante foi lembrado em quatro ocasiões diferentes, enquanto o dono de salão de beleza, o marmiteiro, a sacoleira e a salgadeira foram mencionados três vezes cada. Por fim, outros tipos de negócio mencionados duas vezes foram advogado, boleira, doceira, massagista, padeiro e pedreiro.

É interessante notar que o pipoqueiro aparece em duas peças publicitárias analisadas anteriormente, enquanto manicure figura em apenas uma delas. O cabeleireiro e a costureira são os tipos de negócio mais presentes nos anúncios, porém não foram os mais lembrados durante as entrevistas. Talvez isso aconteça porque a profissão de cabeleireiro seja uma das principais atividades exercidas pelo MEI, segundo a pesquisa do perfil do microempreendedor individual apresentada anteriormente. A doceira, por sua vez, mencionada apenas duas vezes, ocupa lugar de destaque em grandes campanhas veiculadas pelo Sebrae: a campanha de 40 anos e a campanha "Sebrae apresenta". Nota-se, ainda, que em nenhum momento as empresárias são referidas nos anúncios como doceiras. Dora, inclusive, é denominada cake designer, num reflexo da atual "gourmetização do mundo". 
Quanto à classe social, o microempreendedor individual é classificado pelos entrevistados como pertencente à classe C: “o MEI ele é classe C”, “é classe C”, "público C". Alguns consideram também as classes D e E, porém, de maneira complementar. O mais interessante dessa classificação é como ela é adjetivada pelo público entrevistado. Alguns profissionais veem a classe $\mathrm{C}$ como composta por pessoas que ascenderam para a classe média brasileira, ou, em outras palavras, "subiu no país, ela alcançou um status aí, um status quo que ela não tinha antes", enquanto outros avaliam o membro da classe C como aquele que "não tem grana", "o cara bem pobre" ou ainda uma "pessoa mais pobre".

Esse pensamento é refletido na discussão sobre a escolaridade do microempreendedor individual. Segundo a maioria dos entrevistados, o MEI é uma pessoa "menos esclarecida", “que não têm instrução", para a qual a vida foi difícil e não houve oportunidade de adquirir conhecimento formal. Para eles, o microempreendedor individual não tem "nem o $1^{\mathrm{o}}$ grau completo", é "pouquíssimo qualificado, com dificuldade de leitura" e "dificuldade com a tecnologia” e, por fim, “o MEI não é um empresário que procura capacitação [empresarial]”.

Curiosamente, essa percepção sobre a escolaridade do microempreendedor individual é incompatível com os dados de pesquisas recentes. O perfil do microempreendedor individual (SEBRAE, 2013) traz números que mostram que 44,01\% do público possui ensino médio ou técnico completo, e que apenas 16,5\% dos MEI não completaram o ensino fundamental. Somente $0,8 \%$ do público não possui nenhum tipo de instrução formal.

No entanto, alguns entrevistados não compartilham dessa visão desfavorável sobre a escolaridade do MEI, uma vez que há depoimentos que afirmam que "o nível de escolaridade não era tão baixo quanto se pensou", e que há muitos microempreendedores individuais "com graus de escolaridade variados" ou, ainda, que "hoje em dia você tem pessoas que elas buscam mais informação, pessoas que são mais qualificadas, e tal, e elas estão dentro da classe C".

Além disso, mesmo aqueles que acreditam no baixo nível de instrução da categoria reconhecem o espírito empreendedor desses empresários e a importância de suas experiências de vida para os negócios:

tenho gente analfabeta que virou pequeno empresário. Porque o cara tem ensinamentos e conhecimentos sobre gestão avançadíssimos, ele conseguiu virar um pequeno empresário, ele tem um faturamento alto, mas ele não teve escolaridade [...] Ele não é alfabetizado, [...] mas ele conhece o negócio dele, ele tem um conhecimento tácito Essas pessoas elas têm muito conhecimento tácito; elas têm vivência, elas têm experiências, mas elas não têm o conhecimento explícito. 
Essa vivência, citada inúmeras vezes durante as entrevistas, é valorizada tanto pelos profissionais do Sebrae quanto por aqueles das agências publicitárias. A admiração pelo comprometimento dos empresários é percebida em diversos momentos das entrevistas, mas revela-se principalmente na caracterização dos MEI como "batalhadores", aqueles que "matam um leão por dia", que "ralam pra caramba", trabalham "de sol a sol”, "metem a mão na massa", “carregam a empresa nas costas" e são a "galera do corre”, numa referência à informalidade, já que o empreendedor informal não pode parar de trabalhar porque não tem direitos e benefícios, ou seja, está sempre “correndo atrás do prejuízo".

Ainda mais interessante é perceber que, ao mesmo tempo em que valorizam e admiram a dedicação do microempreendedor individual ao seu negócio, há um sentimento de compaixão pela condição social atribuída ao público MEI. Não foram raras as vezes em que o público foi descrito nas entrevistas como pessoas "sofridas", “desamparadas", que vivem "à margem da sociedade" e que foram resgatadas pelo Sebrae e pela formalização. Nesse contexto, o MEI também foi caracterizado como um público "mais simples" e "humilde". É possível que essa percepção surja devido a outro aspecto do público MEI identificado durante a coleta de dados. Para os profissionais do Sebrae e das agências de publicidade, o microempreendedor individual "se sente isolado", é "sozinho" e, por isso, precisa "dar conta sozinho".

[Ele] talvez pense que ninguém faz melhor e ninguém entende melhor o negócio dele do que ele mesmo. Ele é um cara que faz tudo, ele vai ter que cuidar de todos os assuntos, porque ele é o cara mais preocupado com a empresa dele.

Consequentemente, o microempreendedor individual se torna uma pessoa sofrida. Esse aspecto, no entanto, não é visto na representação que se faz dele na publicidade do Sebrae. Ao contrário, o indivíduo retratado como "sofredor" é, justamente, o empreendedor informal. Como descreve a cartilha da campanha "Chegou a sua vez", criada pela agência Giacometti: o trabalhador informal "trabalha até quando está doente", "não amamenta corretamente seus filhos", "não consegue empréstimos bancários", "é recusado como prestador de serviços e fornecedor por pessoas jurídicas", "não tem clientela fiel", "não pode se aposentar" e "não deixa pensão para os filhos após a morte".

Segundo os entrevistados, o MEI não recebe muito apoio em sua caminhada empreendedora, "não enxerga outras possibilidades", "não encontra outros caminhos". Assim, o público é tido como receoso, que desconfia de tudo e todos.

Outra característica atribuída ao microempreendedor individual é consequência da dificuldade em ancorar o conceito. Uma saída encontrada pelos entrevistados foi descrever o 
MEI como o "cara comum". Foram diversas as situações em que o microempreendedor individual foi descrito dessa maneira, conforme descrito na tabela 14.

Tabela 14 - Expressões utilizadas pelos entrevistados para caracterizar o MEI como "cara comum" (continua)

\begin{tabular}{|c|c|}
\hline CARACTERÍSTICA DO MEI & EXPRESSÕES UTILIZADAS \\
\hline \multirow{5}{*}{ O CARA COMUM } & O MEI é o cara comum \\
\hline & Cara de gente comum \\
\hline & Estereótipos de gente comum \\
\hline & O MEI é um cara comum \\
\hline & O MEI é uma pessoa comum \\
\hline \multirow{6}{*}{ O POPULAR } & Popular \\
\hline & Cara de povão \\
\hline & Cara mais de povo \\
\hline & Cara de povo \\
\hline & Povo, popular \\
\hline & Popular \\
\hline \multirow{3}{*}{ O CARA DO VAREJO } & Um cara do varejão \\
\hline & Varejão \\
\hline & $\begin{array}{l}\text { A cara desse público, que é essa coisa } \\
\text { meio varejão mesmo }\end{array}$ \\
\hline \multirow{4}{*}{ GENTE COMO A GENTE } & Pessoa real \\
\hline & Gente como a gente \\
\hline & Gente como a gente \\
\hline & Gente de verdade \\
\hline \multirow{2}{*}{ QUALQUER UM } & Pode ser qualquer um \\
\hline & É qualquer um \\
\hline
\end{tabular}


Tabela 14 - Expressões utilizadas pelos entrevistados para caracterizar o MEI como "cara comum" (conclusão)

\begin{tabular}{|c|l|}
\hline \multirow{2}{*}{ O CARA SIMPLES } & Simples \\
\cline { 2 - 2 } & Cara mais simples \\
\cline { 2 - 2 } & Mais simples \\
\hline PESSOA NEUTRA & Pessoa completamente neutra \\
\hline O CARA BÁSICO & Cara básico assim \\
\cline { 2 - 2 } & Cara mais basicão \\
\hline O CARA QUE USA & A cara que eu vejo quando eu passo na \\
TRANSPORTE PÚBLICO & rodoviária \\
\hline
\end{tabular}

Fonte: elaborada pela autora

É importante destacar que, ao mencionar o microempreendedor individual como uma "pessoa completamente neutra", o entrevistado fazia oposição à imagem do indivíduo que não é MEI e que, na opinião dele, tem "tatuagem ou um brinco". De fato, nenhuma peça analisada apresenta esses elementos na caracterização do microempreendedor individual. Além disso, a percepção de que o MEI é um "cara comum" e "gente como a gente" contribui para outra peculiaridade atribuída a ele pelos entrevistados: o MEI não se vê como empresário.

\footnotetext{
Não passa pela cabeça deles que eles são empresários também [...] muitos deles não entendem ainda que eles são empresários [...] Ele não se reconhece como empresário [...] Esse público não se vê como empresário [...] Eu acho que ele só vê empresário quando ele vê uma empresa física.
}

Para os entrevistados, os microempreendedores individuais ainda não associam o conceito de empresário a si mesmos e a seus empreendimentos, e isso é reflexo do que ocorre na sociedade em geral, uma vez que o termo é comumente objetivado na imagem de um homem vestindo terno e gravata: "empresário é Eike Batista para eles [microempreendedores individuais]".

O mesmo acontece para o conceito de empreendedor: "é uma palavra grande", "nem todos $[. .$.$] conseguiam entender o conceito de empreendedor e quando entediam achavam que$ era algo chique, que era algo que não era com eles, era algo longe deles". Para os entrevistados, essa percepção é refletida na categorização do público como microempreendedor individual: “eles não têm o entendimento assim: "eu sou MEI””, “eles não conhecem esses termos”, “não 
conhecem essas nomenclaturas, não", "ele não se vê nesse termo aí”, “o MEI eu acho que é forçado para ele".

Nesse sentido, a percepção da maioria dos profissionais do Sebrae e das agências corrobora com a pesquisa feita em 2009 e mencionada anteriormente, cujo objetivo era avaliar o impacto social da instituição da figura jurídica do microempreendedor individual.

Há, no entanto, aqueles que acreditam que essa percepção por parte do público mudou. "Tem assim uma faixa muito consciente de que é empresário", "os MEI gerados por oportunidade, eles estão vindo muito mais conscientes", "eu acho que eles têm assimilado isso", “ele já está se apropriando do nome", "todo mundo se reconhece”.

Outra questão mencionada na pesquisa de 2009 e que voltou ao debate durante as entrevistas diz respeito à conotação negativa do nome "microempreendedor individual" e da sigla "MEI". Segundo os entrevistados, "o cara quer se sentir empresário, não quer se sentir muito micro", "ele fala, "eu sou microempreendedor individual, mas eu quero passar a ser empreendedor individual, não quero ser mais micro". Em outras palavras, a conotação negativa do prefixo permanece.

\subsubsection{A representação social do MEI pela diferenciação}

Além de possibilitarem investigar a representação social do microempreendedor individual e suas representações afins, as entrevistas em profundidade realizadas com os profissionais do Sebrae e das agências de publicidade permitiram, também, identificar o MEI pela diferença. Em outras palavras, quem não é um microempreendedor individual? Ou, ainda, quem é microempreendedor individual, mas está "fora do padrão"?

Durante a coleta de dados, muitos entrevistados tiveram dificuldade para descrever o microempreendedor individual e muitos deles recorreram, espontaneamente, à descrição de aspectos opostos àqueles que eles acreditam caracterizarem o MEI. Assim, o microempreendedor não tem "cara de modelo", mas também não tem "muita cara de pobre". Ele também não é muito "bonito". A comunicação para o público não pode apresentar "modelos lindos, maravilhosos, mas também não precisam ser feios ou pobres”. Aparece, nesse momento, a referência ao "cara comum".

O MEI não é "gente de propaganda", porque gente de propaganda é "meio exagerada". Ele também não é "uma pessoa toda arrumada" e muito menos "sofisticada". Dessa forma, o microempreendedor individual não trabalha "com tecnologia, com inovação". Aliás, o empresário categorizado como MEI que trabalha com tecnologia e inovação é o "cara que 
acabou de montar uma startup", ou seja, ele não permanecerá na condição de microempreendedor individual durante muito tempo, porque ele é um MEI "fora do padrão", "fora da curva".

No que diz respeito à classe social, o microempreendedor individual não faz parte das classes A ou B. O empresário que "tem nível superior", "grau de escolaridade alto, $3^{\circ}$ Grau, pelo menos, na maioria das vezes, indo para uma pós, querendo estudar no exterior ou que já morou no exterior" não se encaixa no perfil de MEI. Em alguns momentos, os entrevistados afirmam que há, sim, microempreendedores individuais com "grau de instrução um pouco mais elevado". Porém, logo acrescentam que "isso aí não é a maioria, isso é a minoria". Aquele profissional "recém-formado", "formado no exterior" ou "estudante" também não se encaixa no perfil de MEI.

O microempreendedor individual não é "jovem", não tem "cabelo pintado" nem "tatuagem". Também não anda "engravatado" e normalmente não viaja de avião, não vai ao cinema e nem assiste TV por assinatura: "aeroporto, eu não vou falar com MEI", no plano de mídia "não entraria a TV fechada, não entraria cinema". Por fim, as características físicas daqueles que não são microempreendedores individuais são descritas da seguinte maneira: "não vou botar uma moça loira do olho azul e alta para representar o MEI”, "não é nórdico”, não é "gatona, loura, do cabelão".

\subsubsection{Como deve ser a comunicação direcionada ao MEI?}

Diante do exposto, é possível apresentar como o público entrevistado defende que seja a comunicação direcionada ao MEI, particularmente as estratégias de mídia, a linguagem utilizada nas peças gráficas e a importância dos formadores de opinião para o sucesso da comunicação com o microempreendedor individual.

A mídia defendida como apropriada à comunicação com o MEI, tanto pelo Sebrae, quanto pelas agências, é baseada firmemente no uso de TV aberta, rádio e mídia exterior, o que caracteriza também a comunicação de interesse público no Brasil. Transporte coletivo foi muito citado durante as entrevistas: "MEI a gente pode explorar bastante no metrô", "eu já sei que no metrô eu vou falar para MEI", "paradas de ônibus normalmente eram as mídias prioritárias para MEI". Acredita-se que o microempreendedor individual não possui veículo próprio e, consequentemente, locomove-se utilizando transporte público. A TV aberta ocupa lugar de destaque nos planos de mídia de campanhas direcionadas ao MEI: "sempre vai aparecer lá em cima", "fatalmente a gente vai fazer Esquenta ou vai fazer Faustão". Rádio e revistas populares 
também foram citados pelos entrevistados: "rádio fala muito bem com MEI”, "[revistas] Ana Maria Braga, Ti Ti Ti, Minha Novela".

A internet também é apontada como estratégia de mídia para o público. Ao mesmo tempo em que seu crescimento e abrangência são reconhecidos, sua utilização pelo microempreendedor individual é caracterizada como rudimentar. Em alguns momentos é citado que o MEI apenas acessa a internet em lan houses ou, ainda, que necessita da ajuda de seus filhos, mais jovens, para acessarem a rede.

\begin{abstract}
A internet vem crescendo cada vez mais junto desse público, então muitas vezes você tem uma campanha; você quer uma comunicação, muitas vezes, você não tem uma verba muito alta, você consegue às vezes comunicar através de estratégias de internet. Eles estão se modernizando, por exemplo, WhatsApp, essas coisas todas, você tem gente que as vezes é MEI e que usa Instagram para poder vender. [...] Estão em lan house, eles estão fazendo negócio no Mercado Livre, ou estão vendendo coisas nos classificados, e isso não estavam adicionando conhecimento, eles estavam usando a internet como ferramenta, logo ferramenta para venda. Ele mal sabe o que é WhatsApp, não sabe nem pronunciar WhatsApp.
\end{abstract}

Outra estratégia de comunicação mencionada durante as entrevistas aborda a questão dos formadores de opinião. Para o Sebrae e as agências, a principal figura a exercer influência sobre o público MEI é o comunicador de rádio, ou comunicador local, "porque esses caras têm um alcance muito grande, uma penetração muito grande nesse público", eles "falam com o público que a gente quer atingir". Também foram citadas como personalidades influentes para o público pessoas famosas como Zeca Pagodinho, Regina Casé, Faustão, Ana Maria Braga, Sílvio Santos, Gugu, Henrique Chaves e jogadores de futebol. Além disso, um entrevistado afirmou que "uma personagem de uma novela que naquele momento seja de uma comunidade, seja de uma favela, normalmente tem uma identificação". Essa declaração chama atenção para um aspecto apresentado anteriormente no qual o MEI é percebido como membro da classe $\mathrm{C}$ e, consequentemente, aquele que "não tem grana", "o cara bem pobre", que mora na favela.

A linguagem publicitária mais eficaz para a comunicação com o microempreendedor individual é aquela direta, objetiva, que deixa clara a relação entre os benefícios adquiridos e o pagamento do imposto. Segundo os entrevistados, a comunicação deve "ser direta", "uma coisa rápida", "uma informação já causando a diferença para ele". A simplicidade precisa dar o tom da comunicação, deve ser de "entendimento literal". "Não pode ter nada muito subliminar, muito entrelinhas", "não pode ser muito rebuscado", "não pode levar nada complexo para eles".

Para aproximar o Sebrae do público MEI, é sugerida a utilização da linguagem publicitária de varejo, uma vez que "o tom varejo" é justamente aquele utilizado pelo microempreendedor individual para promover seus produtos e serviços. Em outras palavras, a 
estratégia de comunicação passa pelo emprego da "linguagem que ele usa para fazer a propaganda do negócio dele", que ele "usa no dia a dia dele", a "linguagem dos caras". Essa linguagem é traduzida graficamente pelas referências ao varejo, em particular a elementos presentes em feiras.

\subsubsection{O diminutivo e questões de gênero}

Por fim, faz-se necessário apontar três aspectos que se destacaram durante a realização das entrevistas: o uso do diminutivo para se referir a características do MEI, o emprego de alguns termos que podem ser interpretados como pejorativos e, ainda, questões de gênero relacionadas ao público.

Ao se referirem às atividades desempenhadas por microempreendedores individuais, muitos entrevistados utilizaram os substantivos no diminutivo, como: "marmitinha", "mulher que faz docinho", "salõezinhos pequenininhos", "quitandinha", "quiosquezinho", "salõezinhos de beleza”. É interessante o uso deste recurso expressivo, uma vez que emprega o substantivo em sua forma diminutiva para se referir ao negócio de um MEI. Seu emprego pode ser motivado pela finalidade de se referir a algo, de fato, pequeno, como o negócio de um microempreendedor individual, ou ainda para dar à mensagem conotação afetiva ou depreciativa. Neste trabalho, o emprego do diminutivo para se referir ao negócio de um microempreendedor individual foi identificado em apenas uma campanha e, mesmo assim, ao negócio antes da formalização: “A Luiza trabalhava por conta própria, no seu quartinho".

É necessário cautela, no entanto, pois sua utilização pode causar a impressão de que a referência tem conotação pejorativa, como aconteceu durante uma entrevista em que o microempreendedor individual foi descrito como uma "menina com blusinha qualquer", em mais uma alusão à caracterização do MEI como "pessoa comum" ou "neutra".

O termo "bronco" e "broncão" surgiu durante as entrevistas para caracterizar o MEI, e também pode apresentar caráter pejorativo. Segundo o Novo Dicionário Aurélio da Língua Portuguesa (FERREIRA, 2004, p. 331), o adjetivo significa "[Do lat. vulg. *bruncu] Adj. 1. Tosco, áspero, agreste: rochas broncas. 2. Rude, rústico, inculto; ignorante, ignaro: camponês bronco. 3. V. burro (12)".

Antes de prosseguir e analisar a recepção da mensagem publicitária do Sebrae pelo próprio microempreendedor individual, é preciso chamar atenção para o machismo existente na sociedade atual. Esse machismo manifesta-se, muitas vezes, na comunicação publicitária e em declarações como a seguinte, feita por uma entrevistada: “é muito mais fácil as mulheres 
pegarem uma identificação com uma campanha representada por um homem do que o contrário; a sociedade ainda é muito machista". O mesmo machismo mostrou-se presente em alguns momentos da coleta de dados, em declarações como "é a mulher que tem mais dificuldade, entendeu? O homem, ele é mais safo" e na caracterização da microempreendedora individual como mãe solteira: "a mulher ela não tem marido; ela tem filho, ela tem que manter a casa". Essa caracterização é objetivada durante o merchandising na novela Cama de Gato. A personagem Taís, microempreendedora individual, é mãe solteira e sustenta o filho sem a ajuda do pai, o personagem Bené, representado pelo ator Marcello Novaes. Ainda que discutir e se aprofundar no tema do machismo não seja o objetivo deste trabalho, é importante destacá-lo dentro do contexto analisado pela investigação.

\subsection{O depois: a recepção da mensagem}

Tendo como premissa a importância do papel do receptor no processo comunicacional, é relevante que se estude a apropriação da mensagem e como ela pode influenciar seu significado, aspecto continuamente renovado e transformado por esse processo. Além do conteúdo em si, o contexto, outros indivíduos e outras mensagens podem estar envolvidos e influenciar essa apropriação. Para investigá-la, foram realizados grupos focais com empreendedores que trabalham informalmente e com aqueles que já se formalizaram e são, hoje, microempreendedores individuais.

A pesquisadora viu, na Semana do Microempreendedor Individual, uma oportunidade de identificar e organizar os grupos focais para a investigação. O evento aconteceu no Distrito Federal, entre os dias 13 e 18 de abril de 2015. A Semana do MEI é uma espécie de "feirão" que orienta interessados em se formalizar e oferece cursos, palestras e consultorias em gestão para os microempreendedores individuais. A iniciativa acontece simultaneamente em todo o Brasil e é organizada pelo Sistema Sebrae com o apoio de parceiros. No Distrito Federal, 27 pontos de atendimento foram montados pelo Sebrae/DF onde eram oferecidos cursos, palestras, oficinas, consultorias, rodadas e encontros de negócios, todos gratuitos. As inscrições para as oficinas aconteciam pela internet ou, ainda, no próprio local do evento, se houvesse vagas. A tenda principal da Semana do MEI estava localizada no centro da cidade satélite de Ceilândia, onde foram realizados os grupos focais para esta pesquisa (figura 32). 
Figura 32 - Tenda principal da Semana do Microempreendedor Individual no centro de Ceilândia
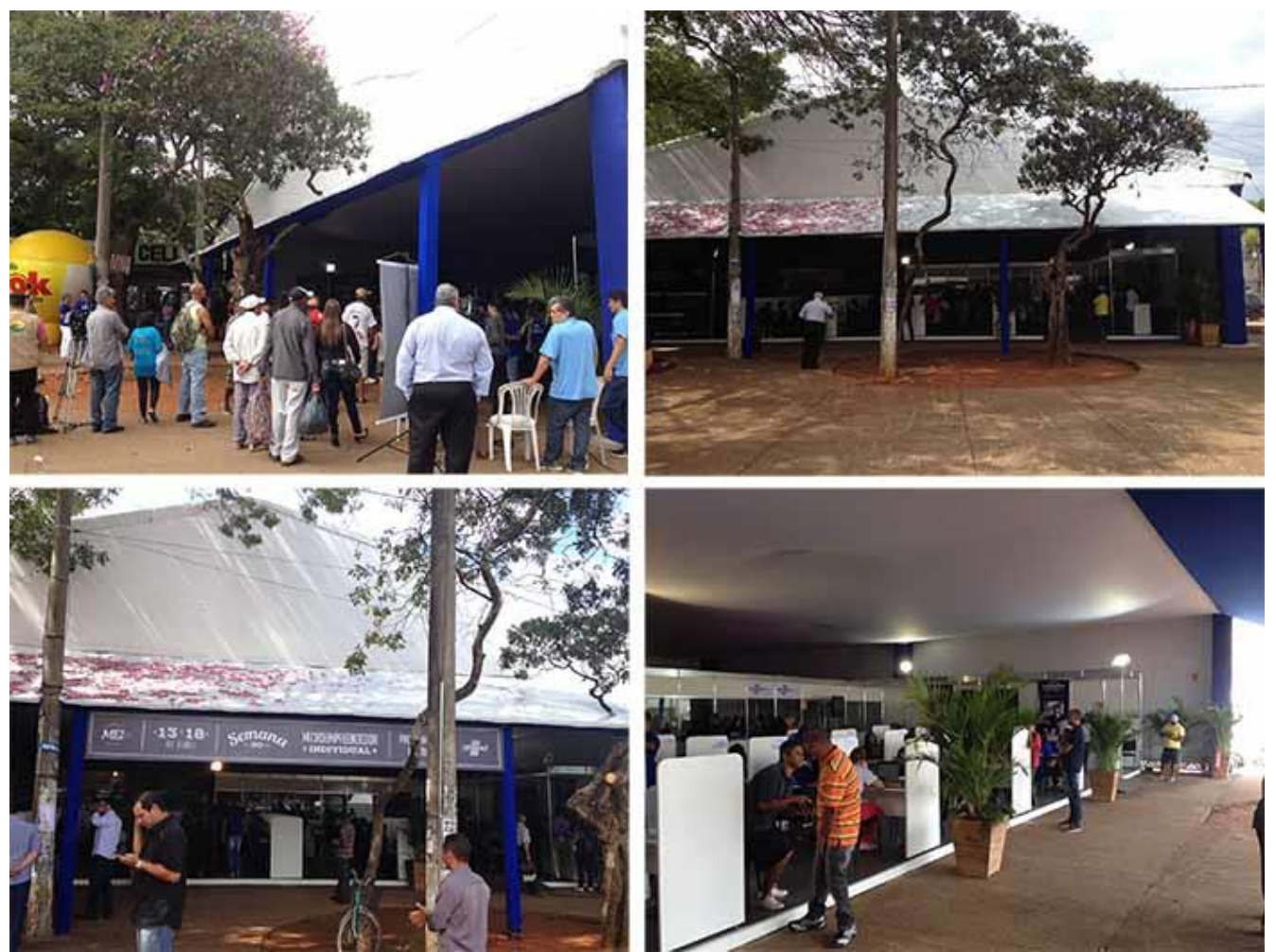

Fonte: registros feitos pela autora

A pesquisadora conseguiu apoio da organização do evento para aplicar a pesquisa durante 4 dias, em 4 diferentes turmas participantes de oficinas SEI. Assim, foram realizados 4 grupos focais nas manhãs dos dias 13, 14, 15 e 16 de abril. Participaram, ao todo, 58 pessoas, dos quais 31 eram homens e 27 mulheres, sendo alguns deles microempreendedores individuais formalizados e outros empreendedores informais em busca de informações sobre a formalização. Os grupos participaram das seguintes capacitações: “Como divulgar sua empresa na internet", "SEI Controlar meu dinheiro", "SEI Empreender" e "SEI Unir forças (para melhorar)". Dessas, as oficinas "Como divulgar sua empresa na internet" e "SEI Controlar meu dinheiro" ficaram lotadas.

A sala onde eram ministradas as oficinas eram equipadas com datashow, quadro branco do tipo cavalete e cadeiras escolares. Cada participante recebia uma pasta personalizada com a arte da Semana do MEI, onde havia o material do curso (pasta grampeada com textos e atividades), bloco de anotações personalizado, folder da Semana do MEI, folder Circuito Empreendedor, formulário de avaliação da oficina (tanto do instrutor quanto da organização do evento), caneta e ficha de cadastro (figura 33). O folder Circuito Empreendedor apresenta todo o calendário de eventos e cursos do semestre promovidos pelo Sebrae, no Distrito Federal (para todos os públicos, não apenas para o MEI). 
Figura 33 - Folder da Semana do MEI e formulário de avaliação das oficinas

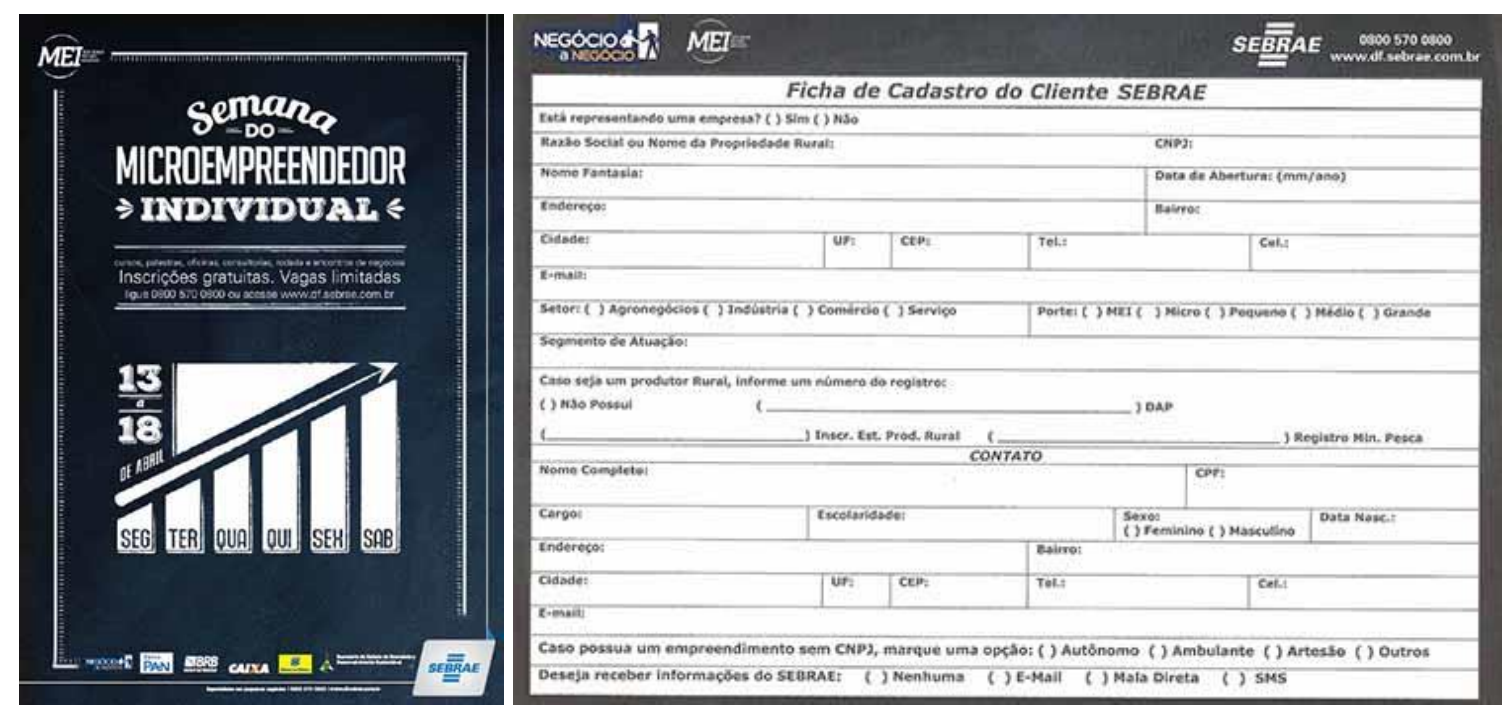

Fonte: material fornecido pelo Sebrae

A abordagem do público acontecia já em sala de aula. A pesquisadora era apresentada à turma pelo instrutor que, em seguida, lhe passava a palavra, para ser iniciada a dinâmica. Apenas duas pessoas não quiseram participar da pesquisa e não se manifestaram durante a coleta de dados. Houve boa adesão, mesmo que a contribuição de alguns tenha sido pequena.

A conversa inicial buscou traçar um perfil dos empresários, conforme roteiro a seguir:

1) Informações de perfil: nome, idade, breve histórico familiar, ramo de negócio.

2) Como é o seu dia a dia como empresário? Cansativo? Difícil? Você se sente realizado após um dia de trabalho?

3) O que espera para o futuro de sua empresa? Espera crescer? Contratar mais funcionários, ampliar a carteira de produtos/serviços?

Depois, a pesquisadora apresentava ao grupo imagens representativas do MEI desconectadas das peças publicitárias e pedia para os participantes comentarem sobre as pessoas retratadas. A estratégia pretendia avaliar a questão da complementaridade entre texto e imagem verificada na análise dos anúncios. Além disso, buscava identificar algum elemento que remetesse à representação social do microempreendedor individual, em especial à sua objetivação, já que eram apresentadas apenas as imagens, sem texto. Também foi verificada nessa etapa a forma como o público se referiu às pessoas retratadas: se, por exemplo, alguém mencionou que ambos poderiam ser microempreendedores individuais ou, ainda, se os 
caracterizou como empreendedores ou empresários. O roteiro dessa etapa da dinâmica é apresentado abaixo:

1) Descreva a imagem com suas palavras.

2) Como você imagina a vida da pessoa retratada?

3) Você acha que a pessoa retratada na imagem tem algo em comum com você?

Fazer uso de fotografias em dinâmicas de grupo é uma estratégia que busca estimular ainda mais a produção de sentido e, assim, extrair informações adicionais e importantes ao contexto da investigação. Como afirmou González Rey (2005, p. 66), “as fotos são uma via idônea para provocar emoções e situar o sujeito em uma temporalidade subjetiva vivida, que, com frequência, é mais difícil de ser conseguida por outras vias". De fato, observou-se que as fotos provocaram reações imediatas no público, alterando o clima do grupo e permitindo que se expressassem mais a partir daquele estímulo.

A última etapa na condução dos grupos consistia em apresentar aos participantes as imagens dos MEI no contexto da peça publicitária, assim como foi veiculada na mídia. A discussão foi estimulada por perguntas como as descritas a seguir:

1) Qual a sua opinião sobre o anúncio?

2) O que você acha dos empresários apresentados no leiaute?

3) Você, como empresário, se vê retratado na peça publicitária apresentada?

4) Por quê?

A dinâmica com cada grupo durou, em média, 20 minutos, gerando uma hora e meia de áudio, também degravado pela empresa Brasília Degravações. A pesquisadora buscou analisar o material da mesma forma que as entrevistas, ou seja, buscando zonas de produção de sentido e interpretando o conteúdo gerado com base nas referências teóricas que norteiam o trabalho. Foi possível aprofundar o conhecimento sobre o microempreendedor individual, em especial no que diz respeito a sua representação social, traços de personalidade e como ele interpreta a publicidade do Sebrae. Essas descobertas são apresentadas a seguir. 


\subsubsection{O participante da Semana do Microempreendedor Individual}

Dos 31 homens e 27 mulheres participantes das dinâmicas, a maioria era formada por sacoleiros. Daqueles que ainda não eram microempreendedores individuais, seis estavam desempregados, dois eram servidores públicos, um era estudante e um trabalhava como estoquista, atividade não permitida como MEI. A tabela 15 apresenta a variedade de ramos de negócio dos participantes dos grupos.

Tabela 15 - Atividades empreendedoras desempenhadas pelos participantes dos grupos focais

\begin{tabular}{|c|c|c|c|}
\hline ATIVIDADE & PARTICIPANTES & ATIVIDADE & PARTICIPANTES \\
\hline Artesão & 2 & Dono de lanchonete & 1 \\
\hline Bombeiro eletricista & 2 & Dono de restaurante & 1 \\
\hline Borracheiro & 1 & Dono de salão de beleza & 1 \\
\hline Cabeleireiro & 2 & Estoquista & 1 \\
\hline Costureira & 3 & Estudante & 1 \\
\hline Desempregado & 6 & Fotógrafo & 2 \\
\hline $\begin{array}{l}\text { Dona de ateliê de roupas } \\
\text { de festa }\end{array}$ & 1 & Marceneiro & 1 \\
\hline Dona de brechó & 1 & Marmiteiro & 2 \\
\hline $\begin{array}{l}\text { Dona de empresa de } \\
\text { consultoria (coaching) }\end{array}$ & 2 & Músico & 1 \\
\hline Dona de loja de roupas & 1 & $\begin{array}{l}\text { Dono de empresa de } \\
\text { organização de festas } \\
\text { infantis }\end{array}$ & 2 \\
\hline $\begin{array}{l}\text { Dono de agência de } \\
\text { comunicação }\end{array}$ & 2 & Sacoleiro & 11 \\
\hline Dono de bar & 1 & Servidor público & 2 \\
\hline $\begin{array}{l}\text { Dono de empresa de } \\
\text { balões personalizados }\end{array}$ & 1 & $\begin{array}{l}\text { Técnico em } \\
\text { computadores }\end{array}$ & 1 \\
\hline $\begin{array}{l}\text { Dono de empresa de } \\
\text { transporte/turismo }\end{array}$ & 2 & Vendedor de bicicletas & 1 \\
\hline Dono de imobiliária & 2 & Vendedor de calçados & 1 \\
\hline
\end{tabular}


A escolaridade de todos os participantes do grupo não pôde ser averiguada. Porém, pelo menos cinco microempreendedores individuais declararam ter ensino superior completo e um revelou estar cursando faculdade. As formações variaram entre psicólogo, pedagogo, engenheiro de produção, contador e educador físico.

A busca pelo Sebrae foi motivada, para a maioria dos participantes, pela necessidade de adquirir conhecimentos em gestão. Foram inúmeros os depoimentos que afirmaram procurar o Sebrae para "aprender mais, conhecer mais", "aprender para continuar" e "adquirir conhecimentos". Também foi mencionada a busca por "informações de gestão" e "orientação". Também houve quem afirmasse procurar o Sebrae para "aprender a administrar", "aprimorar" e "aprofundar mais ainda" o conhecimento sobre o mercado.

Outro aspecto bastante citado pelos participantes como motivador para procurarem o Sebrae foi a necessidade de ampliar seus negócios. Depoimentos como "quero espalhar a minha empresa para o Brasil todo", "quero abrir minha própria loja" e "quero lançar minha própria marca" foram alguns vistos durante as dinâmicas. Alguns empresários mencionaram, também, a necessidade de ampliar sua produção devido ao aumento das vendas e citaram a procura por linhas de crédito para a compra de máquinas.

A cooperação empresarial também foi lembrada pelos empresários. Para eles, o Sebrae pode ajudá-los a unir forças uns com os outros e formar parcerias. O tema da cooperação esteve bastante presente nas discussões, assim como a questão da fidelização de clientes. Muitos empresários mencionaram que o Sebrae pode auxiliá-los a melhorar o atendimento e realizar relacionamento com seus clientes. "Vocês pesquisam satisfação de cliente, expectativa, essas coisas? É isso que eu quero aprender".

Questões como nota fiscal eletrônica também foram mencionadas, assim como a reorganização da empresa. Alguns empresários declararam estar passando por dificuldades e apontaram claramente o Sebrae como apoiador para mudar a situação de seus empreendimentos, em depoimentos como: "o primeiro ano foi muito bom, mas eu me desorganizei e estou tentando juntar os caquinhos aí" e "vim aqui ao Sebrae para poder arrumar um outro jeito para conseguir levar a minha vida”.

Curiosamente, nenhum empresário foi explícito ao afirmar que busca o Sebrae para vender mais, apesar de ficar subentendido que todas as ações na busca de melhoria da empresa têm como objetivo final aumentar o faturamento do negócio. 


\subsubsection{O dia a dia do empreendedorismo}

Durante as dinâmicas com os grupos, a referência ao sonho de empreender foi recorrente. Foram inúmeras as declarações como "para mim era um sonho", "sempre tive o sonho de montar meu atelier", "aquele sonho que você tem" e "nós tínhamos já esse sonho". De todos os microempreendedores individuais ouvidos, apenas uma senhora declarou que nunca quis empreender, e sim que identificou no empreendedorismo uma maneira de ganhar a vida ao mesmo tempo em que precisava cuidar da mãe doente em casa.

A questão do sonho está ligada também à satisfação pessoal proporcionada pelo empreendedorismo. Todos os MEI declararam se sentirem realizados por serem donos de seus próprios negócios, em depoimentos como: "tenho uma satisfação pessoal”, "eu me sinto realizada", sinto "satisfação, porque eu gosto", "uma realização pessoal". Outros, ainda, afirmaram que o empreendedorismo permite que eles sejam eles mesmos: "ser eu de verdade", e que o dinheiro não é o mais importante ao empreender: "a pessoa tem que fazer com amor. [...] não é só o retorno financeiro, não é? Isso aí é muito relativo".

Tanto o sonho do empreendedorismo, quanto a satisfação pessoal são trabalhados na publicidade do Sebrae. Campanhas como "Empreendedor Individual", criada pela agência Giacometti em 2010, mostra a realização de um sonho ao trazer as histórias de vida de Jorge, cujo negócio permitiu que ele tivesse uma aposentadoria tranquila ao lado dos netos, e de Luiza, a costureira que se aposentou e deixou sua empresa sob a administração dos filhos. $\mathrm{O}$ merchandising da campanha na novela da Rede Globo também deixa evidente a questão do sonho de empreender, mencionado inúmeras vezes pela personagem Taís. Outras campanhas, como a de 40 anos, cujo slogan é "O negócio é acreditar" e a campanha "Sebrae Apresenta", que traz a história da cake designer Dora, também se utilizam do sonho do empreendedorismo como argumento para persuadir o público.

Outra questão mencionada pela maioria dos entrevistados refere-se à dificuldade de se conseguir apoio para empreender. Muitos ouvem de amigos e parentes que são loucos e que o negócio "não vai dar certo".

"Você é louca, você bateu com a cabeça?" "Eu costuro". "Mas, você? O que é isso? Mas por quê? Então assim, às vezes o empreendedorismo é difícil até nisso. Parece que você vai contra tudo e todos. "Você é louca, você vai fazer coisa dessa... É tão difícil” [...] "“"Não vai dar certo". 
Em todos os grupos focais, apenas uma empresária afirmou ter recebido apoio e incentivo dos familiares e ex-colegas de trabalho:

Da parte de amigos de trabalho sempre me incentivaram... Isso que me levou a sair do meu, não é? Do emprego [...] Minha família também me apoiou muito [...] Em geral as pessoas costumam pensar assim: "nossa, e se isso não der certo?", não é? Mas eu tive ao contrário. Algumas incentivam, mas a maioria não.

Apesar de mencionarem o sonho do empreendedorismo, a maioria dos empresários apontou o desemprego como uma das principais razões que os levou a empreender. Depoimentos como "recentemente fui despedida da empresa", "a gente conseguir trabalho não é fácil" e "eu trabalhava fixo, não é? A empresa não me aceitava, não me aceitou" são alguns exemplos. Outro grande motivador do empreendedorismo apontado pelos entrevistados foi a liberdade para colocar em prática suas próprias ideias, ou seja, ter mais autonomia.

Pela liberdade, poder fazer outras coisas, não ficar ali preso só o dia inteiro só dentro do escritório, cumprindo ordens, essas coisas todas, não é? E ter uma liberdade, fazer o que a gente gosta, não é? Ter também uma visão lá na frente, e pensar positivo que pode dar certo, e investir nisso. Eu pensei dessa forma.

Além disso, a figura do chefe é, algumas vezes, retratada pelo público como um obstáculo ao crescimento profissional e pessoal:

\footnotetext{
Você tá trabalhando para você mesmo, você tá tendo uma renda para você, não tá dando expectativa para o seu patrão [...] Às vezes a gente tem uma ideia e leva para o patrão, não é? Só que o patrão ainda assim, por falta ainda de visão futura... aquela ideia que você tem, que poderia melhorar o empreendimento, não vai para frente. Então eu falei assim: "então eu não quero colocar em prática essa ideia" [...] Trabalhar às vezes para o outro, se esforçando bastante, para ele ficar rico, milionário e você ganhando aquela... aquele tantinho, pouco.
}

As campanhas do Sebrae buscam valorizar a liberdade e a independência do microempreendedor individual ao ancorarem o conceito com expressões como "trabalha por conta própria" e "dono do seu negócio", e também ao objetivarem o MEI em anúncios nos quais ele aparece trabalhando com um funcionário, ou seja, o microempreendedor é o chefe, o patrão.

Em relação às dificuldades do dia a dia, a mais citada durante a coleta de dados foi a burocracia, desde aquela para formalizar o negócio até a aquela necessária para realizar importação de mercadorias. "Isso aí é complicado. Para importar, eu tenho que ter outro documento específico de importação. Eu estou assim meio perdida". Outros pontos mencionados pelos empresários foram a concorrência e a falta de organização: "não sei como 
colocar as coisas em ordem”, "eu comecei a misturar os números e os ganhos, aí ficou aquela coisa muito bagunçada" e "no ano passado que deu uma bagunçada".

Além disso, muitos mencionaram o cansaço por trabalharem sozinhos e serem responsáveis por tudo: "é mais difícil ser o nosso chefe". A falta de dinheiro também foi lembrada, em depoimentos como "está me faltando capital", assim como o valor dos impostos: "a contribuição baixou, mas não foi tanto. Deveria ter abaixado mais".

\subsubsection{A representação social do MEI pelo MEI}

Para identificar a representação social do microempreendedor individual entre o próprio público buscou-se, durante a análise dos grupos, termos e expressões que estivessem diretamente ligados à ancoragem e à objetivação do conceito. Foi possível identificar a ancoragem de forma clara no discurso dos empresários. A objetivação, porém, não foi identificada.

\subsubsection{A ancoragem}

A maior parte dos microempreendedores individuais participantes da pesquisa apresentou-se como "microempreendedor individual" ou, ainda, utilizando a sigla "MEI": “montei um MEI", "formalizamos o MEI". Muitos também referiram a si mesmos pela atividade desempenhada, como por exemplo: "sou artesã", "sou sacoleira" ou "sou costureira". Essas duas formas de ancoragem do conceito de microempreendedor individual foram as mais recorrentes durante as dinâmicas com os grupos, tanto para descrever a si mesmos como empreendedores, quanto para se referir a outros microempreendedores individuais.

O público também utilizou o termo "empreendedor" para se referir a suas atividades profissionais ou mencionar o conceito de MEI, enquanto outros empregaram a palavra empresa: "empresa formalizada", "nós já temos a empresa", "minha empresa" e "abri uma microempresa". Outros se apresentaram como "empresário" ou "microempresário" e afirmaram ter "meu próprio empreendimento" ou "próprio negócio".

Além das expressões citadas anteriormente, utilizadas para classificar o microempreendedor individual, outras surgiram ao longo da coleta de dados, porém de maneira menos frequente. São elas: "sou registrada", "sou autônomo", “é fichado" e, ainda, ser microempreendedora individual é "ser sua patroa". 


\subsubsection{A objetivação}

Não foi possível identificar a objetivação do conceito de microempreendedor individual durante os grupos focais, uma vez que os participantes da pesquisa teriam que refletir sobre a própria aparência ou a de seus pares para tornar tangível o conceito de MEI. Uma possibilidade de objetivação do conceito se apresentou durante a discussão das imagens. Porém, nenhum participante mencionou qualquer característica dos MEI apresentados como sendo típicas de microempreendedores individuais.

Para suprir essa lacuna, este trabalho buscou investigar a objetivação do conceito utilizando imagens de microempreendedores individuais apresentadas no livro 5 anos Microempreendedor Individual - MEI: um fenômeno de inclusão produtiva. A publicação, lançada em fevereiro de 2015, comemora o quinto ano desde a criação do MEI e as 5 milhões de empresas formalizadas e enquadradas nessa categoria empresarial. O livro apresenta depoimentos e histórias de sucesso de 38 microempreendedores individuais. As imagens dos MEI são apresentadas na figura 34 e servirão como referência para a identificar a objetivação do conceito. É importante destacar que há apenas 37 imagens, tendo em vista que um dos casos de sucesso apresentado no livro não possui foto da empresária.

Figura 34 - Imagens de microempreendedores individuais apresentadas no livro 5 anos Microempreendedor Individual - MEI: um fenômeno de inclusão produtiva

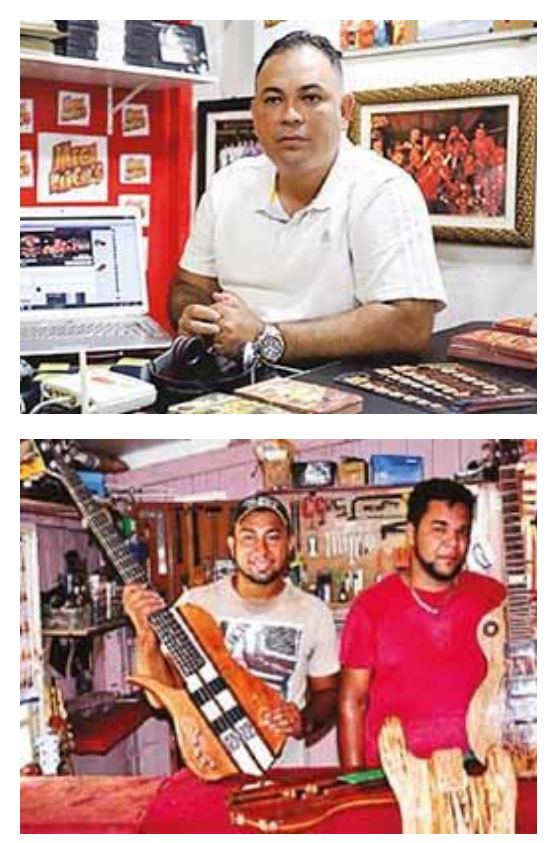

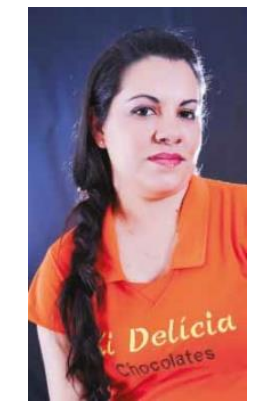

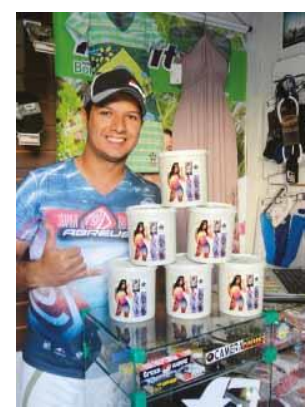

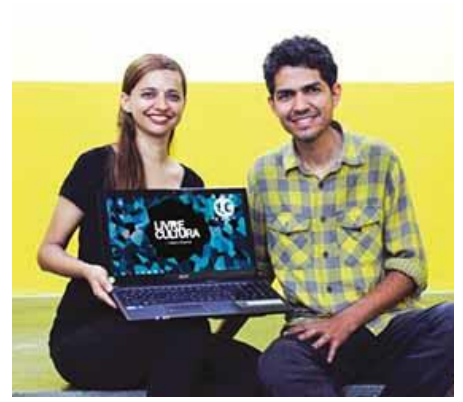

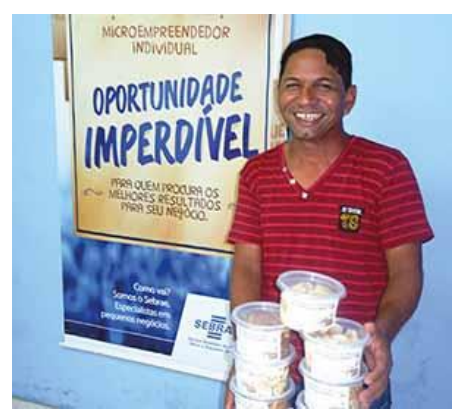



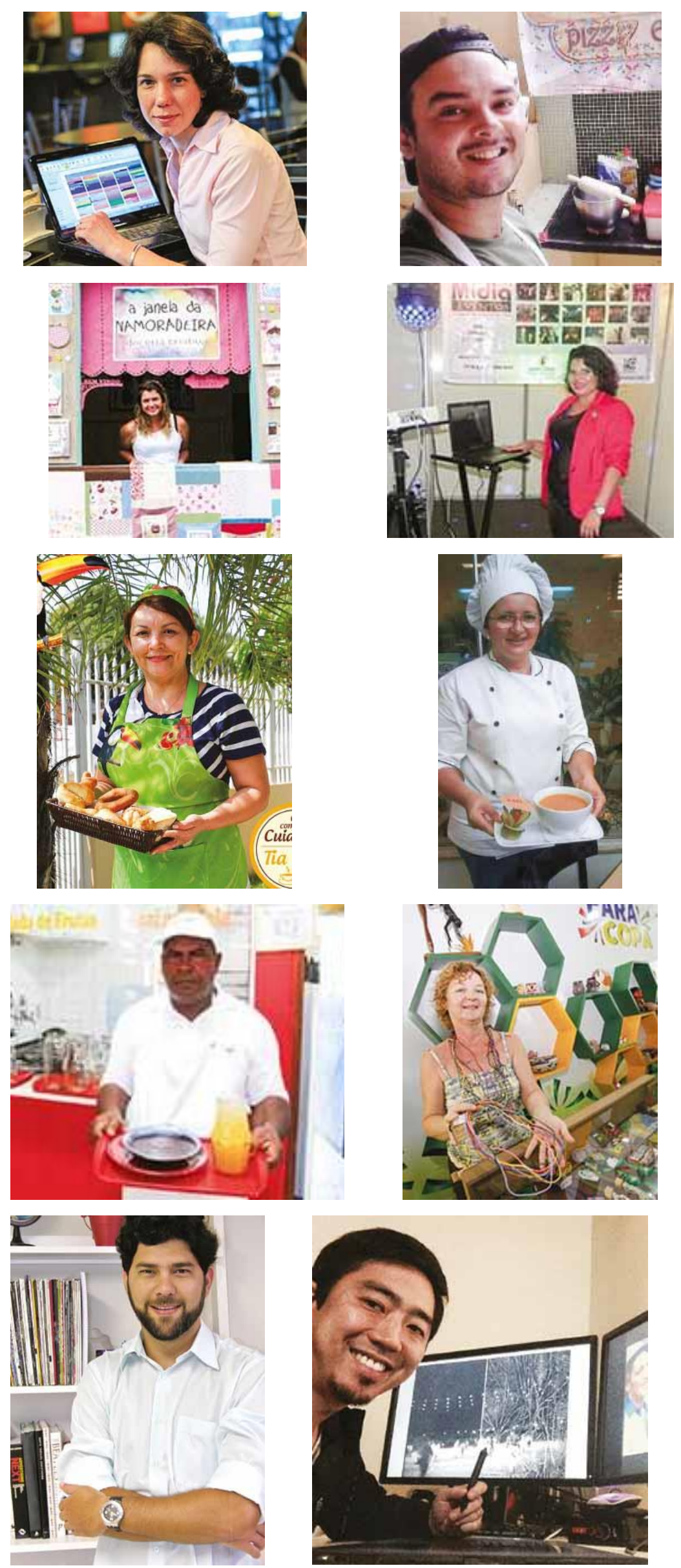
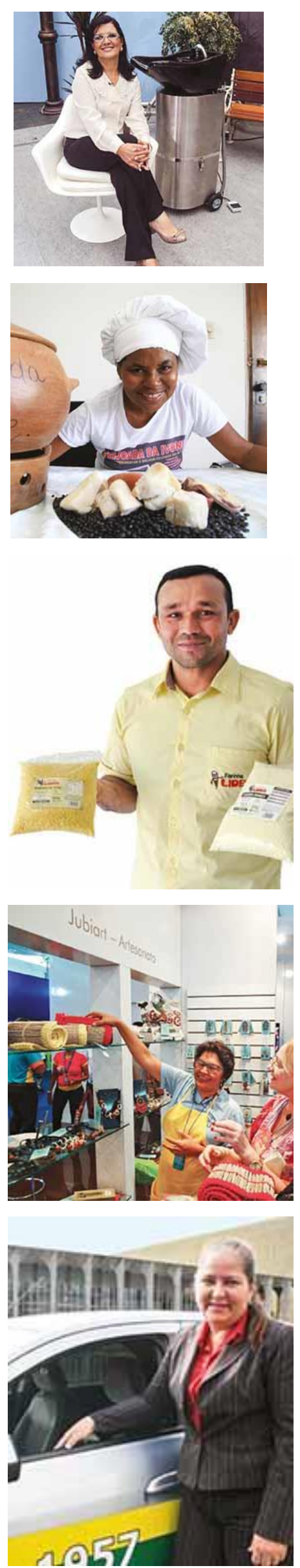

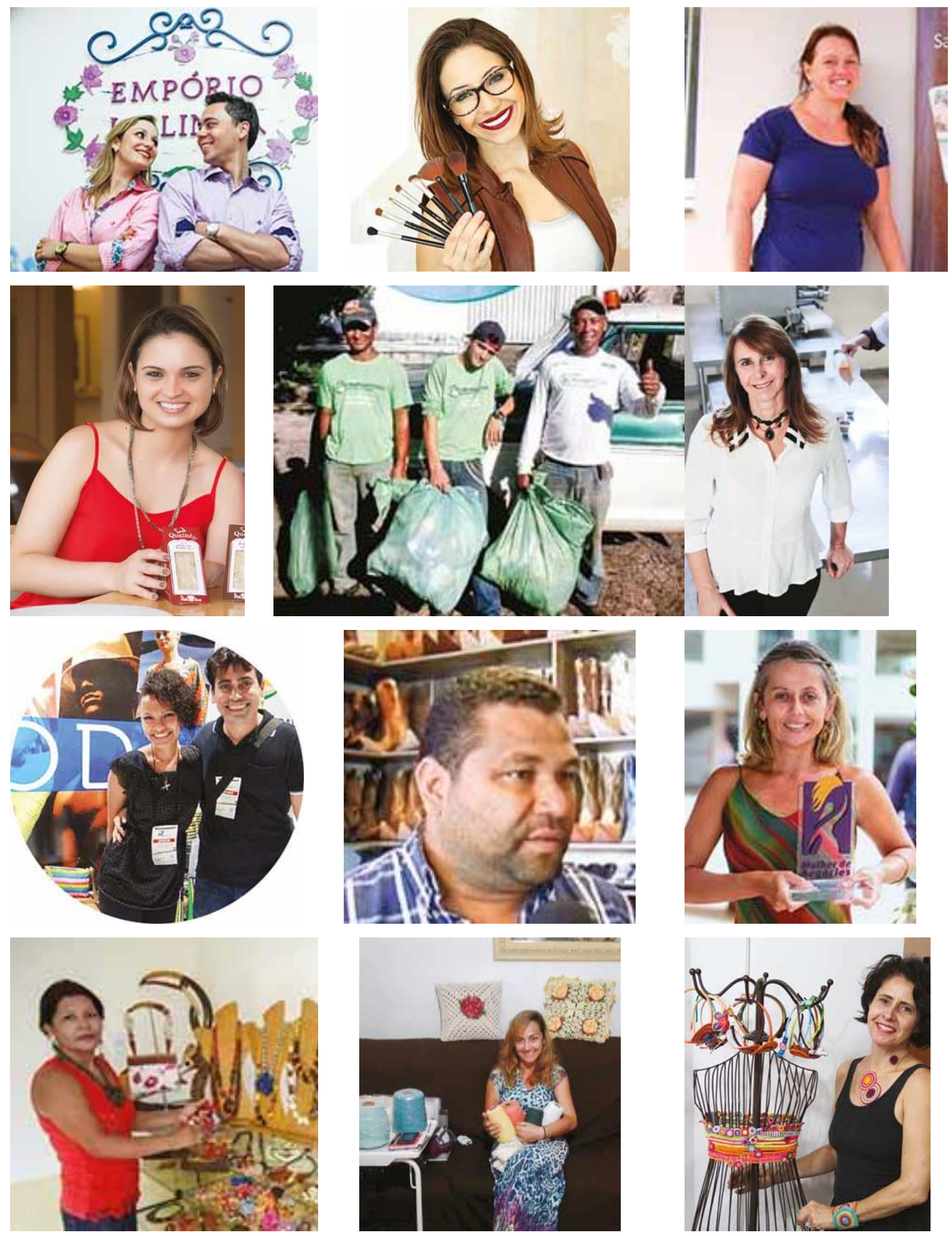

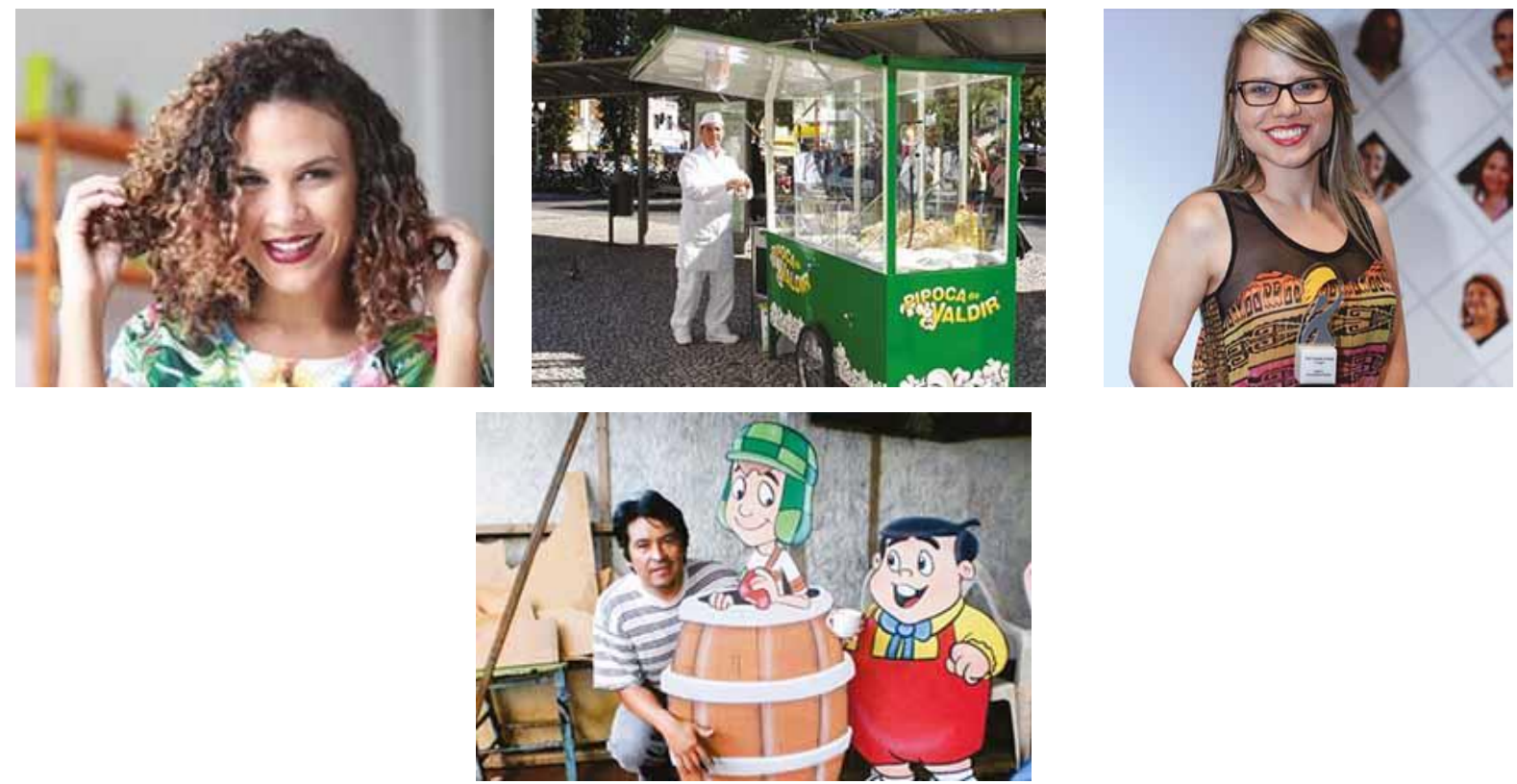

Fonte: SEBRAE, Serviço Brasileiro de Apoio às Micro e Pequenas Empresas. 5 anos - Microempreendedor individual - MEI: um fenômeno de inclusão produtiva. Brasília: SEBRAE, 2015.

Das 37 imagens apresentadas, 22 são de mulheres, 13 de homens e duas de casais empreendedores. A média de idade aparente dos microempreendedores individuais é de cerca de 40 anos. Quanto à cor da pele, pode-se dizer que 19 são brancos, 13 são pardos, seis são negros e um é amarelo. Enquanto alguns posam para as fotos vestindo uniformes, a maioria veste roupas casuais. Assim, a objetivação do conceito de MEI baseado nas imagens de microempreendedores individuais pode ser resumida como apresentado pela tabela 16, a seguir.

Tabela 16 - A representação social do MEI na esfera da recepção da mensagem

\begin{tabular}{|c|c|}
\hline \multicolumn{2}{|c|}{ REPRESENTAÇÃO SOCIAL } \\
\hline \hline ANCORAGEM & OBJETIVAÇÃo \\
\hline \hline "MEI" & Mulher, 40 anos, branca, veste roupa casual \\
\hline
\end{tabular}

Fonte: elaborado pela autora

\subsubsection{As representações afins}

Durante a realização dos grupos focais, os participantes descreveram de diversas maneiras a si mesmos e a seus pares como empresários. Percebe-se que o conceito de microempreendedor individual carrega consigo uma série de representações afins que complementam o significado do termo para esse público. 
Assim, o microempreendedor individual é descrito como uma pessoa criativa, cheia de ideias para vender seu produto. "Sem criatividade a pessoa acho que não chega a lugar nenhum". É corajoso por enfrentar "situações diferentes" sem medo e tem "visão de futuro". Percebe as oportunidades do mercado e não perde tempo em explorá-las. "Às vezes as pessoas estacionam, mas o MEI não estaciona”. Ele é persistente e acredita em seu negócio, que é bemsucedido porque ele está sempre "vigiando bem de pertinho". "Para dar certo eu acho que a pessoa tem que estar dentro e comprando, abrir seu negócio e ficar em cima mesmo". O MEI deve ter também postura profissional, deve demonstrar formalidade no atendimento, ser "sério" e "saber manter certa distância". "Minha postura como empreendedora é simpatia, mas não uma simpatia mão aberta".

O microempreendedor individual é um empresário esforçado, "trabalhador", que tem “vontade de aprender". "Não adianta eu falar que eu vou fazer algo sendo que eu não conheço, e aí eu vou me prejudicar", "tem que saber comprar, tem que saber vender". Para isso, faz pesquisa de mercado, busca parcerias e inova para "personalizar", ter "um diferencial" a oferecer para o cliente e assim, vender mais e "ter mais dinheiro". Por ser MEI, é uma "pessoa que vai ter os seus direitos", mais "segura", mas que mesmo assim se preocupa com seu negócio e com a concorrência. Outros querem "roubar o seu cliente" e "todo mundo vai querer a sua ideia".

É chamado de louco por empreender, mas o empreendedorismo lhe dá a oportunidade de "pôr em prática aquilo que a gente acha que pode melhorar", dá "liberdade" para "fazer o que gosta", "fazer com amor". Por fim, o microempreendedor individual é descrito pelo próprio público como um empresário feliz, alegre e realizado.

\subsubsection{A representação imagética do microempreendedor individual na publicidade do Sebrae}

Em determinado momento, durante a realização dos grupos focais, os participantes eram solicitados a comentar duas imagens, uma de um homem e outra de uma mulher, sem qualquer identificação, conforme apresentado na figura 35. As imagens faziam parte de um anúncio do Sebrae que divulgava a Semana do Microempreendedor Individual. A peça publicitária foi apresentada aos participantes posteriormente (figura 36), quando se discutiu a representação social do microempreendedor individual na publicidade do Sebrae. 
Figura 35 - Imagens utilizadas nas dinâmicas dos grupos focais
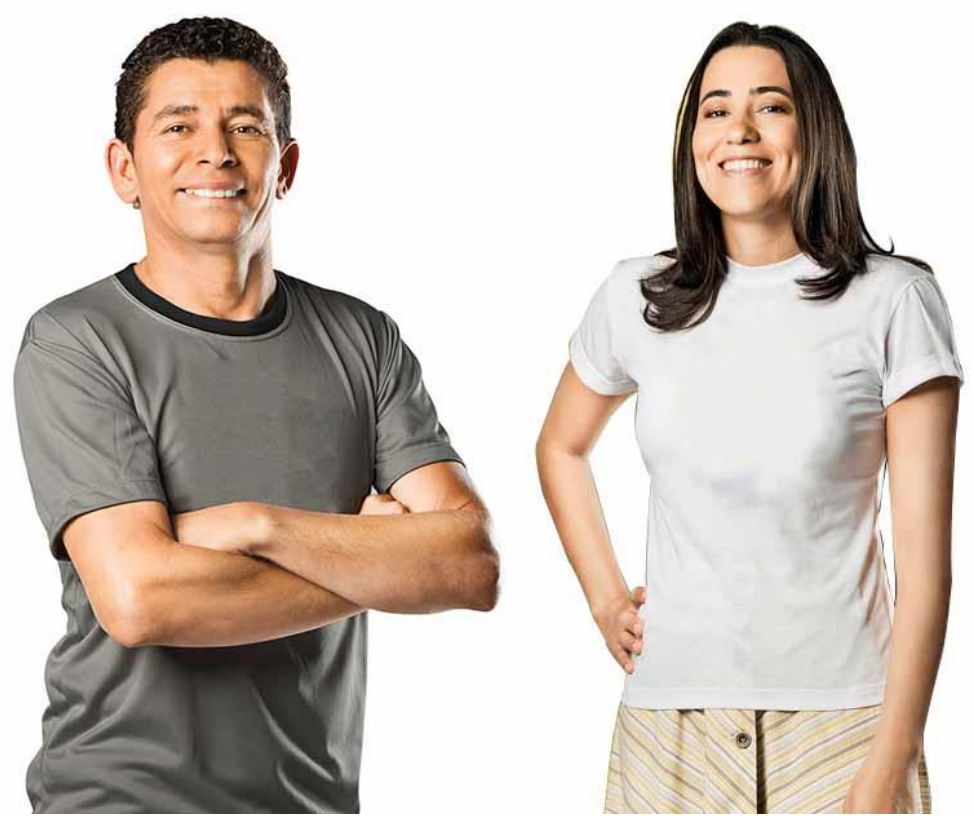

Fonte: imagens elaboradas pela autora a partir de anúncio fornecido pelo Sebrae

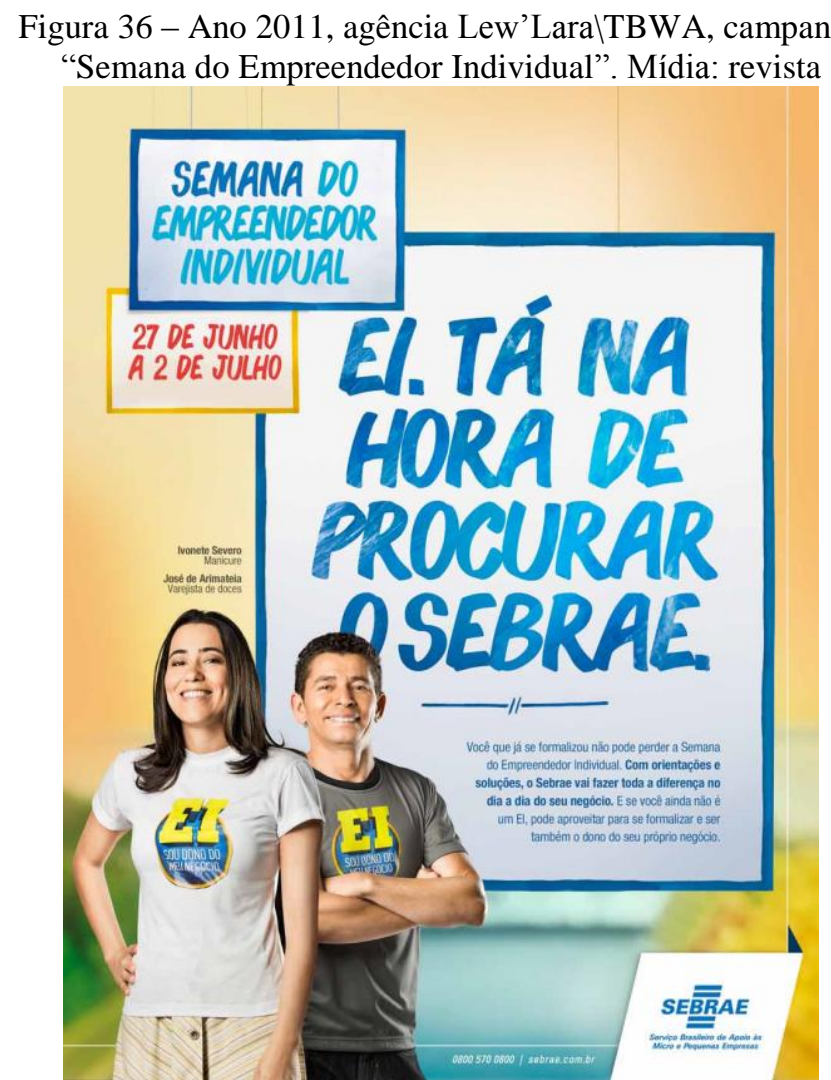

Fonte: material fornecido pelo Sebrae

Nenhum participante descreveu o casal como empresário, empreendedor ou, ainda, propôs uma atividade profissional para qualquer um dos dois. Os comentários giraram em torno 
da emoção passada pela imagem. Foi destacada a alegria transmitida pelas fotografias e a simpatia das pessoas retratadas: "eu acho que os dois estão felizes, não é?", "caras de bem, bem felizes, não é?", “a primeira coisa que eu vejo aí é simpatia”, eles estão "mantendo a simpatia". Também foi mencionado que ambos "têm um grau de satisfação no rosto, no olhar" e que "estão muito bem resolvidos".

Apesar de a primeira impressão ter sido positiva, a postura corporal do homem logo incomodou: "por mais que ele esteja sorrindo, ele está travado por causa do braço", "todo mundo que está assim significa que é dependente de alguma coisa", "ficar de braços cruzados é um fator negativo". Para os empresários, os braços cruzados revelam algum tipo de "resistência" e o homem está "mais fechado", "mesmo com um sorriso no rosto".

Embora essa percepção tenha sido partilhada pela maioria dos participantes - a postura corporal do homem foi citada em todos os quatro grupos focais de maneira espontânea - ela não foi unânime. Alguns empresários destacaram que braços cruzados nem sempre indicam algo negativo: "acabo tirando pelos estudos comportamentais que não é bem assim mais não, hein? O negócio está abrindo...", "metade das pessoas hoje vive de braços cruzados". De qualquer maneira, a imagem da mulher teve recepção claramente mais favorável. Ela foi descrita pelos entrevistados como "aberta", "ela está solta, ela está tipo me mostrando algo bem acertado".

Quando questionados sobre a possibilidade de os modelos serem empresários, as opiniões foram negativas: "eu acho que não", "condizente com a roupa e com a posição do corpo, eu acredito que não". Outros, porém, consideraram que, "se forem empresários, todo mundo está satisfeito".

Após serem apresentados à imagem do anúncio publicitário e tendo sido revelado que os modelos são, de fato, microempreendedores individuais, percebe-se uma mudança na avaliação dos entrevistados, em comentários como: "são pessoas realizadas", "é o sonho delas" e "na área que eles estão, parece que estão ganhando dinheiro, não é?". Além disso, a postura corporal do homem ganhou outro significado: "eu acho que ele não tá nem aí para o que os outros pensam. O importante é que ele tá feliz". Um dos entrevistados interpretou o anúncio como um convite à formalização e capacitação, exatamente como pretendido pelo Sebrae: "mais um incentivo para todos nós. Ah, um incentivo, porque eles estão bem. Você vê que eles são microempreendedores individuais. Está tendo resultado".

Ao comparar a imagem dos empresários no anúncio com a imagem que fazem de si mesmos, surgem diferentes percepções. Há quem não se sinta representado porque os modelos estão muito felizes, denotando a preocupação que acompanha o empresário no dia a dia: "acho 
que não parece comigo. Eu acho que eu não me identifiquei porque eu acho que ela está feliz demais". Outros não se sentem representados e esperam uma associação mais direta com seu ramo de negócio por meio da vestimenta do modelo: "se tivesse vestido, o seu traje estivesse com uma determinada formalidade a mais, não é? Para vincular o meu produto com a própria pessoa", “[Faltou] a questão da profissão [...] o meu produto".

Houve ainda quem avaliasse o anúncio de maneira positiva e se identificasse com a imagem dos microempreendedores individuais: "sim, me sinto representado pela imagem", "parece mesmo [comigo]". A legenda das fotos, que destaca a atividade empreendedora dos modelos, não prejudicou a comunicação: “eu acho que só muda o segmento, não é?”. Além disso, o espírito empreendedor foi destacado por alguns entrevistados como o elo para a identificação com o anúncio: "representa sim. Pela atitude que eles tiveram, não é? De "o nosso projeto é esse", e colocar o próprio negócio e fazer investimentos. Pensar num futuro melhor".

Por fim, um dos participantes afirmou se identificar com ambos os empresários destacados na peça, porém por razões diferentes:

me vejo das duas formas. Muitas das vezes quando eu atendo o cliente eu mostro para ele que eu estou bem, total liberdade. Quando eu encontro comigo mesmo, eu vejo as despesas, os gastos, eu já cruzo os braços e...

Durante a discussão sobre a representação do MEI nas peças publicitárias, percebe-se que o próprio público compreende a dificuldade em retratá-lo. Ao comentar sobre a campanha da Semana do MEI de 2015 (figura 37), cujo leiaute não apresenta imagens do MEI, um empresário afirma: "Você não falou [na peça] "olha, uma pessoa que é empreendedora é assim". Não, porque tem muito tipo de gente. Muito. Tem, por exemplo, borracheiro, tem máquina de cartão e ele não é assim". Outro complementa: "Personalizar a coisa é difícil. Às vezes não tem nada personalizado". A expressão "personalizar" é utilizada diversas vezes pelos entrevistados para se referir ao recurso da representação imagética do microempreendedor individual na publicidade. 
Figura 37 - Leiaute da campanha de divulgação da Semana do Microempreendedor Individual de 2015

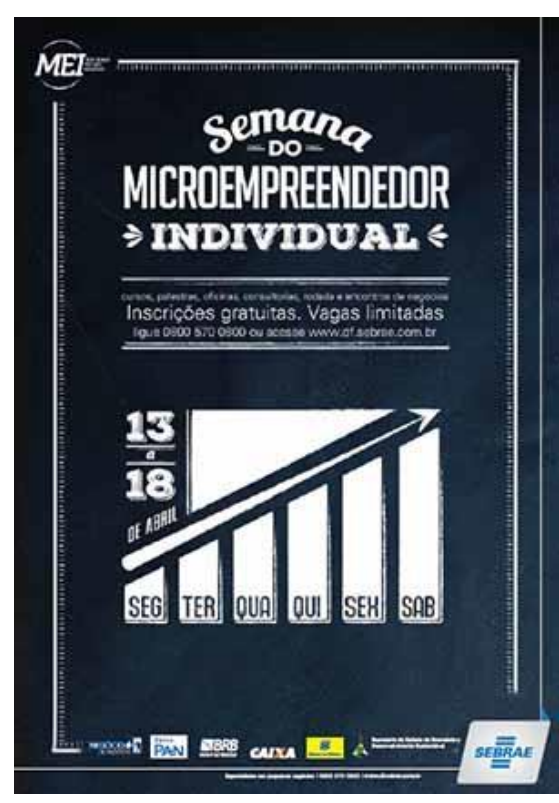

Fonte: material fornecido pelo Sebrae

Ainda sobre a campanha de 2015, muitos depoimentos apontam para a efetividade da comunicação sem a necessidade de uma imagem representativa do MEI: "se você for observar, você não personalizou nada", "o que acontece, você põe só a informação, da forma como você precisava passar, mas você não personalizou”. E finalizam: “talvez seja melhor dessa forma que está aí [sem imagens]. Mais direto, “olha, a informação que você precisa é”, porque ninguém aqui pode perder tempo. O mundo não é assim hoje?”.

Mesmo que a campanha de divulgação da Semana do Microempreendedor Individual de 2015 não faça parte do corpus de pesquisa, tanto pela data de veiculação das peças, quanto por não apresentar imagens representativas do MEI, considerou-se pertinente apontar a percepção do público sobre essa comunicação específica, uma vez que ele foi impactado por ela. Essa decisão mostra-se acertada, uma vez que a relevância da imagem para a peça publicitária foi questionada pelos próprios receptores da mensagem inaugurando, assim, uma nova zona de sentido para reflexão. De fato, o poder de comunicação da representação imagética é contestado pelo público MEI e a reflexão é direcionada para o processo de recepção da mensagem publicitária:

acho que você fazer uma leitura de uma pessoa é muito perigoso. Existe toda uma questão por trás de cada pessoa. Existe o você conhecer, você entrevistar, entendeu? Então, o estereótipo é uma coisa meio perigosa nesse ponto aí. [...] Cada pessoa vai fazer uma leitura diferente [...] Esse é o problema que as pessoas têm. É até um negócio meio perigoso. As pessoas tentarem entender fisicamente uma pessoa, 
digamos. [...] A gente não consegue mais classificar ninguém [...] Muitas aparências enganam não é?

O trabalho de campo proposto na fase de interpretação da hermenêutica teve como objetivo acrescentar ao cenário de pesquisa informações que permitam compreender o fenômeno comunicacional sobre o microempreendedor individual de forma abrangente. Ao avaliar vários aspectos de um mesmo fenômeno, buscou-se compreender como os significados das mensagens foram interpretados e reinterpretados pelos receptores, bem como trazer à superfície os processos implícitos que envolvem a decodificação dessas mensagens e, a partir deste procedimento, entender a resposta do público à comunicação (THOMPSON, 1995, p. 406 e 407).

Nas palavras de Thompson (Id., p. 404), "esclarecer os modos típicos de apropriação é identificar algumas das maneiras características como os produtos comunicativos são recebidos e usados pelas pessoas". Também foi possível compreender melhor como ocorre, a partir da interpretação das mensagens, o processo de identificação do público-alvo com a representação visual do MEI presente no material de comunicação do Sebrae.

\section{CONCLUSÃO}

O presente trabalho buscou responder como ocorre a identificação do microempreendedor individual (MEI) face à representação que se faz desse público nas campanhas publicitárias nacionais criadas e veiculadas pelo Sebrae entre os anos de 2009 e 2014.

Para isso, foi empregado o referencial metodológico da hermenêutica de profundidade elaborado pelo sociólogo John B. Thompson, que permite analisar formas simbólicas presentes em fenômenos complexos, tal qual aquele da comunicação de massa. Assim, o trabalho de pesquisa foi organizado em três fases: a fundamentação teórica ou, na classificação de Thompson, a análise sócio histórica; a análise formal, onde foram analisados os anúncios do Sebrae criados para o microempreendedor individual e, por fim, a interpretação ou reinterpretação, onde foram estudadas as esferas de produção e recepção da mensagem por meio da realização de entrevistas e grupos focais.

Diante de todos os dados levantados e das análises realizadas, conclui-se que a representação social do microempreendedor individual ainda é um conceito novo, que está em

processo de assimilação. Como afirmou Moscovici (Apud SÁ, 1993, p. 22), algumas representações sociais "nem sempre tiveram tempo suficiente para permitir a sedimentação que 
as tornasse tradições imutáveis". A representação social do MEI, nesse sentido, corresponde à descrição do autor, uma vez que a figura jurídica é recente, criada em 2009.

Assim, é possível afirmar que representação social do MEI é ancorada no termo "trabalha por conta própria", mas sua objetivação adquire, conforme descreveu Ibañez (Apud SÁ, 2002, p. 41), “uma série de opiniões e de imagens relativamente desconexas", percebidas em diferentes momentos do trabalho.

A objetivação do conceito encontrada nos anúncios analisados, por exemplo, foi aquela correspondente a de um homem, com cerca de 40 anos, pardo, que veste uniforme. Já na esfera de produção da mensagem publicitária, o MEI foi objetivado como homem, também com 40 anos, porém negro e vestindo calça jeans e camiseta. Por fim, ao analisar a imagem dos microempreendedores individuais apresentada no livro comemorativo dos 5 anos da figura jurídica, outra objetivação foi identificada: mulher, com cerca de 40 anos, branca e sem uniforme de trabalho. O único aspecto comum nas três objetivações do conceito reside na idade média do MEI: 40 anos.

Nesse sentido, o diálogo estabelecido entre as esferas de produção e recepção da mensagem, ou seja, entre o Sebrae e o microempreendedor individual, ainda se encontra numa etapa inicial, apesar de já ter se modificado bastante desde a criação da figura jurídica. Além disso, a multiplicidade de imagens associadas ao MEI não deve ser vista necessariamente como complicador da comunicação, mas sim como uma oportunidade para explorar significados e estratégias persuasivas. Prova disso é que, mesmo com a dificuldade de objetivação do conceito, a pesquisa realizada identificou que o público receptor da mensagem é impactado e compreende a publicidade do Sebrae, uma vez que não espera ver nela um espelho de si mesmo, mas sim uma tentativa de representação da categoria empresarial à qual pertence. Em outras palavras, grande parte do público entrevistado demonstrou entendimento acerca da utilização da imagem como ferramenta de persuasão, cuja função é apresentar o grupo dos microempreendedores individuais, o que ocorre mesmo quando a atividade apresentada no anúncio é diferente daquela que ele desempenha. Ele também compreende a dificuldade de objetivar o conceito.

Alguns recursos parecem auxiliar a identificação do público com a imagem: um deles é a caracterização do modelo com uniforme de trabalho, em especial o avental, e a outra é a postura corporal descontraída, uma vez que os braços cruzados do MEI no anúncio discutido pelos empresários foram apontados como característica negativa da peça. No entanto, apesar de compor o imaginário do público, o uniforme pode ser um elemento ambíguo, uma vez que é possível associá-lo ao dono do negócio, mas, também, a um funcionário da empresa. 
Por fim, conclui-se que, assim com o contexto histórico e cultural se modificaram ao longo dos anos, algumas características do público MEI também mudaram desde sua criação. A comunicação do Sebrae passa a anunciar, além da ideia de formalização, os produtos e serviços da entidade para a capacitação do público. É possível perceber, por exemplo, que a publicidade da Semana do MEI de 2015 direciona seus esforços de persuasão para a necessidade de gestão do empreendedor, atendida pelos produtos e serviços da entidade. A campanha não menciona a formalização. Além disso, atualmente há apenas uma campanha anual de maior abrangência para o microempreendedor individual: aquela que divulga a Semana do MEI. Notase, também, que, diferentemente do que pensam o Sebrae e as agências de publicidade, hoje o microempreendedor individual já compreende os conceitos de empreendedor, empresário e MEI, e se identifica como tal. Além disso, esse público entende a importância e necessidade da capacitação empresarial e a busca por conhecimentos de gestão para seus negócios.

\subsection{Limitações da pesquisa}

Toda investigação científica apresenta limitações. Seus resultados podem ser relativos, incompletos ou provisórios (LAVILLE; DIONE, 1999, p. 96 e 97), ainda que não invalidem o conhecimento construído. É importante registrar alguns dos desafios encontrados durante a realização desta pesquisa. Ao longo de todo o processo, a consciência das limitações da investigação permitiu que a vigilância metodológica fosse reforçada para garantir o bom andamento da pesquisa e o alcance de resultados relevantes.

$\mathrm{O}$ primeiro aspecto a ser considerado é justamente o incentivo dado pelo Sebrae à realização deste trabalho, uma vez que a autora é funcionária da entidade e esteve em período de licença para realizar a investigação. Uma possível tendenciosidade pode ser questionada, já que a autora faz parte do cenário de pesquisa, conhece os interlocutores entrevistados e participa do processo de produção das mensagens publicitárias. A hermenêutica de profundidade revelase adequada para abordar essa questão, uma vez que esse referencial teórico-metodológico diminui o risco de vieses na análise ao permitir estudar o fenômeno de forma global.

A metodologia de pesquisa em si também traz limitações. Apesar de não invalidar o processo, a opção pela interpretação, terceira fase da hermenêutica, é uma decisão arriscada na medida em que esta é, por si só, complexa, e estará sempre aberta à discussão (THOMPSON, 1995, p. 376). Ainda assim, a interpretação supre a lacuna deixada pelas análises sócio histórica e formal ao trabalhar a perspectiva da "construção criativa do significado, isto é, de uma explicação interpretativa do que está representado ou do que é dito" (Id., p. 375). Além disso, 
a interpretação permite dialogar com o contexto histórico e cultural na qual a investigação se insere, e também com os processos de negociação de significados, tanto o significado de microempreendedor individual quanto os de empreendedor e empresário.

Outras limitações apresentadas pela metodologia referem-se à generalização dos resultados a partir de uma amostra do universo, no caso, o universo dos microempreendedores individuais.

A questão orçamentária foi outra limitação presente no trabalho, pois impediu a realização de grupos focais fora do Distrito Federal, já que o Sebrae não arcou com despesas diretamente relacionadas à investigação. Além disso, a duração de cada grupo focal foi limitada a 20 minutos, já que o horário das oficinas não poderia atrasar muito e a dinâmica era conduzida no início da manhã. Outra dificuldade enfrentada na coleta de dados com os grupos foi o barulho gerado pela movimentação de pessoas na tenda montada para a Semana do MEI, além do barulho de outras capacitações e palestras realizadas em salas adjacentes. Dessa forma, o áudio ficou prejudicado em alguns momentos da dinâmica, mesmo com o uso de microfones pela pesquisadora, pelo instrutor e pelos participantes. Felizmente, grande parte das informações perdidas conseguiram ser recuperadas por meio de anotações feitas durante a coleta de dados.

Por fim, não é possível estudar a apropriação das mensagens publicitárias do Sebrae em seu contexto original de veiculação. Grupo focais proporcionam um ambiente parcialmente controlado, onde o processo comunicacional acontece de maneira voluntária e na presença de outros indivíduos. Em outras palavras, espera-se que o público participante da pesquisa esteja predisposto a avaliar as mensagens apresentadas e discuti-las. Nessas condições, o contexto de apropriação da mensagem difere bastante em relação àquele no qual a comunicação é normalmente consumida.

Condição semelhante é percebida nas entrevistas, uma vez que o contexto social e histórico no qual a pesquisa foi realizada difere daquele dos últimos 5 anos, período no qual as mensagens foram criadas. Assim, ao discorrer sobre o público microempreendedor individual e a publicidade criada para ele pelo Sebrae, a avaliação dos entrevistados carregava novas informações e reflexões sobre aquele tema, tanto pelo tempo que se passou desde a criação da figura jurídica quanto pelas experiências adquiridas pelo trabalho com esse público ao longo dos anos. 


\section{REFERÊNCIAS}

ABEP, Associação Brasileira de Empresas de Pesquisa. Critério de Classificação

Econômica Brasil. São Paulo: ABEP, 2009.

ABRIC, Jean-Claude. A abordagem estrutural das representações sociais. In: MOREIRA, Antônia S. P.; OLIVEIRA, Denise Cristina de (Org.) Estudos interdisciplinares de representação social. Goiânia: AB Editora, 2000. P. 27-38.

ALMEIDA, Angela Maria de Oliveira. A pesquisa em representações sociais: proposições teórico-metodológicas In: SANTOS, Maria de Fátima de Souza; ALMEIDA, Leda Maria de. (Org.) Diálogos com a teoria das representações sociais. Recife: Editora Universitária, 2005. P. 119-160.

ALMEIDA, Alberto Carlos. A cabeça do brasileiro. Rio de Janeiro: Record, 2007.

ASN, Agência Sebrae de Notícias. Classe C é a que mais empreende no Brasil. Disponível em: <http://www.agenciasebrae.com.br/noticia/19328122/ultimas-noticias/classe-c-e-a-quemais-empreende-no-brasil/>. Acesso em: 26 set. 2013.

AUMONT, Jacques. A imagem. $7^{\circ}$ Edição. Campinas: Papirus, 2007.

BARNES, Barry. Interests and the growth of knowledge. London; Boston: Routledge and K. Paul, 1977.

BERSGTRÖM, Bo. Fundamentos da comunicação visual. São Paulo: Rosari, 2009.

BRAGA, José Luiz. "Constituição do campo da comunicação”. Verso e Reverso. XXV (58): 62-77, jan/abr, 2011. Disponível em:

<http://revistas.unisinos.br/index.php/versoereverso/article/download/924/147>. Acesso em: 15 mar. 2014.

BURKE, Peter J.; STETS, Jan E. Identity Theory. New York: Oxford University Press, 2009. 
CHABROL, Claude. RADU, Miruna. Psicologia da comunicação e persuasão: teorias e aplicações. Lisboa: Instituto Piaget, 2010.

CHALHUB, Samira, 1946-1998. A meta-linguagem. São Paulo: Ática, 2005. Funções da linguagem. 12a Edição. São Paulo: Ática, 2006.

CITELLI, Adilson. Linguagem e persuasão. 11ª Edição. São Paulo: Ática, 1997.

COSTA, João Roberto Vieira da. (Org.). Comunicação de interesse público: ideias que movem pessoas e fazem um mundo melhor. São Paulo: Jaboticaba, 2006.

COSTA, Maria Eugênia Belczak. Grupo focal. In: DUARTE, Jorge; BARROS, Antônio (Org.). Métodos e técnicas de pesquisa em comunicação. 2a Edição. São Paulo: Atlas, 2012. P. 180-192.

COUTINHO, Iluska. Leitura e análise da imagem. In: DUARTE, Jorge; BARROS, Antônio (Org.). Métodos e técnicas de pesquisa em comunicação. $2^{\text {a }}$ Edição. São Paulo: Atlas, 2012. P. 330-344.

DIEESE, Departamento Intersindical de Estatística e Estudos Socioeconômicos; SEBRAE, Serviço Brasileiro de Apoio às Micro e Pequenas Empresas (Org.). Anuário do trabalho na micro e pequena empresa: 2012. $5^{\text {a }}$ Edição. Brasília: DIEESE, 2012.

DOISE, Willem. George. Debating social representantions. In: BREAKWELL, Glynis M.; CANTER, David V. (Org.) Empirical approaches to social representations. Oxford: Clarendon Press, 1993. P. 157-170.

DUARTE, Jorge. Entrevista em profundidade. In: DUARTE, Jorge; BARROS, Antônio (Org.). Métodos e técnicas de pesquisa em comunicação. 2 ${ }^{\text {a }}$ Edição. São Paulo: Atlas, 2012. P. 62-83. 
FERREIRA, Aurélio Buarque de Holanda. Novo dicionário Aurélio da língua portuguesa. Curitiba: Positivo, 2004.

FLUSSER, Vilém. O mundo codificado: por uma filosofia do design e da comunicação. São Paulo: Cosac Naify, 2013.

FORMIGA SOBRINHO, Asdrúbal Borges. Personagem, pessoa e propaganda. In: FORMIGA SOBRINHO, Asdrúbal Borges; GHESTI, Ivânia (Org.). Personagens da Propaganda Brasileira. Vol I. Brasília: Universa, 2004. P. 7-49.

FRANÇA, Vera Veiga. O objeto da comunicação/A comunicação como objeto. In: HOHLFELDT, Antonio; MARTINO, Luiz C.; FRANÇA, Vera Veiga (Org.). Teorias da Comunicação: conceitos, escolas e tendências. $3^{\text {a }}$ Edição. Petrópolis, RJ: Vozes, 2001. P. $39-53$.

GASKELL, George. Entrevistas individuais e grupais. In: BAUER, Martin W.; GASKELL, George. Pesquisa qualitativa com texto, imagem e som: um manual prático. $9^{\text {a }}$ Edição. Petrópolis: Vozes, 2011. P. 64-89.

GONZÁLEZ REY, Fernando. Pesquisa qualitativa e subjetividade: os processos de construção da informação. São Paulo: Pioneira Thomson Learning, 2005.

HALL, Stuart. A identidade cultural na pós-modernidade. $11^{\text {a }}$ Edição. Rio de Janeiro: DP\&A, 2011.

IBGE, Instituto Brasileiro de Geografia e Estatística. Censo Demográfico 2010: características da população e dos domicílios. Resultados do universo. Rio de Janeiro: IBGE, 2011.

IBQP, Instituto Brasileiro de Qualidade e Produtividade; SEBRAE, Serviço Brasileiro de Apoio às Micro e Pequenas Empresas; FGV, Fundação Getúlio Vargas. GEM - Global Entrepreneurship Monitor: Empreendedorismo no Brasil. Relatório Executivo 2012. Imprensa da Universidade Federal do Paraná (UFPR): Curitiba, 2012. 
JAKOBSON, Roman. Linguística e comunicação. São Paulo: Cultrix, 2003.

JOLY, Martine. Introdução à análise da imagem. 14ª Edição. Campinas, SP: Papirus, 2012.

KOSSOY, Boris. Realidades e ficções na trama fotográfica. $3^{\text {a }}$ Edição. São Paulo: Ateliê Editorial, 2002.

LANGE, Talvani. A publicidade e a carnavalização - O caso do anúncio da vodca Smirnoff. In: BARBOSA, Ivan Santos (Org.). Os sentidos da publicidade: estudos interdisciplinares. São Paulo: Pioneira Thomson Learning, 2005. P. 17-28.

LAVILLE, C. e DIONE, J. A construção do saber: manual de metodologia da pesquisa em ciências humanas. Porto Alegre: Artmed; Belo Horizonte: Editora UFMG, 1999.

LOPES, Maria Immacolata Vassallo de. "Pesquisa de comunicação: questões epistemológicas, teóricas e metodológicas”. In: Revista Intercom. São Paulo, Volume XXVII, $n^{\circ}$ 1, jan/jun, 2004. Disponível em:

<http://www.portcom.intercom.org.br/revistas/index.php/revistaintercom/article/view/1056/9 57>. Acesso em: 28 mai. 2014.

MAGIOGLOU, Thalia. The creative dimension of lay thinking in the case of the representation of democracy for greek youth. Culture \& Psychology, Amiens, v. 14, n. 4, p. 442- 466, 2008.

MARCONDES, Pyr. Uma história da propaganda brasileira. Rio de Janeiro: Ediouro, 2002.

MARCOVITCH, Elizabeth Speers. A linguagem universal - A comunicação transcultural nas sociedades globalizadas. In: BARBOSA, Ivan Santos (Org.). Os sentidos da publicidade: estudos interdisciplinares. São Paulo: Pioneira Thomson Learning, 2005. P. 71-80. 
MARTINO, Luiz C. De qual comunicação estamos falando? In: HOHLFELDT, Antonio; MARTINO, Luiz C.; FRANÇA, Vera Veiga (Org.). Teorias da Comunicação: conceitos, escolas e tendências. $3^{\text {a }}$ Edição. Petrópolis, RJ: Vozes, 2001. P. 11-25.

MARTINO, Luiz C. Interdisciplinaridade e objeto de estudo da comunicação. In: HOHLFELDT, Antonio; MARTINO, Luiz C.; FRANÇA, Vera Veiga (Org.). Teorias da Comunicação: conceitos, escolas e tendências. $3^{\text {a }}$ Edição. Petrópolis, RJ: Vozes, 2001a. P. 27-38.

MARTINO, Luiz C. Teorias da Comunicação: Muitas ou poucas? Cotia: Ateliê Editorial, 2007.

MEIRELLES, Renato. O empreendedor e a nova classe média brasileira: oportunidades de negócio em um mercado de 1 trilhão de reais. São Paulo: Data Popular, 2012.

Disponível em:

$<$ http://www.portaldodesenvolvimento.org.br/encontros/materiais/27nov1.pdf >. Acesso em: 26 set. 2013.

MOSCOVICI, Serge. A representação social da psicanálise. Rio de Janeiro: Zahar Editores, 1978.

Representações sociais: investigações em psicologia social. $9^{a}$ Edição. Petrópolis, RJ: Vozes, 2012.

NÖTH, Winfried; SANTAELLA, Lucia. Imagem: cognição, semiótica, mídia. São Paulo: Iluminuras, 1998.

PAVARINO, Rosana Nantes. A relevância da teoria das representações sociais para as pesquisas em comunicação de massa. 2003. Dissertação (Mestrado em Comunicação) Faculdade de Comunicação, Universidade de Brasília, Brasília, 2003.

Panorama histórico-conceitual da publicidade. 2013. Tese (Doutorado em Comunicação) - Faculdade de Comunicação, Universidade de Brasília, Brasília, 2013. 
PENN, Gemma. Análise semiótica de imagens paradas. In: BAUER, Martin W.; GASKELL, George. Pesquisa qualitativa com texto, imagem e som: um manual prático. $9^{a}$ Edição. Petrópolis: Vozes, 2011. P. 319-342.

PETRUCCELLI, José Luis; SABOIA, Ana Lucia (Org.). Características Étnico-raciais da População: classificações e identidades. Rio de Janeiro: IBGE, 2013.

PINHEIRO, Odette de Godoy. Entrevista: uma prática discursiva. In: Práticas discursivas e produção de sentidos no cotidiano. SPINK, Mary Jane P. (Org). Rio de Janeiro: Cortez, 2004. P 156-187.

ROSE, Diana. Análise de imagens em movimento. In: BAUER, Martin W.; GASKELL, George. Pesquisa qualitativa com texto, imagem e som: um manual prático. $9^{a}$ Edição. Petrópolis: Vozes, 2011. P. 343-364.

ROUQUETTE, Michel-Louis. Social representations and mass communication research. In: SMITH, Charles W. (Org.) Journal for the theory of social behaviour. Oxford/Cambridge: Blackwell Publishers, 1996. P. 221-231.

RUSSELL, Bernard. Research methods in anthropology: qualitative and quantitative approaches. $3^{\text {a }}$ Edição. Walnut Creek: Altamira Press, 2002.

SÁ, Celso Pereira de. Representações sociais: o conceito e o estado atual da teoria. In: SPINK, Mary Jane (Org.) O conhecimento no cotidiano: as representações sociais na perspectiva da psicologia social. São Paulo: Brasiliense, 1993. P. 19-45.

Núcleo central das representações sociais. 2ª Edição. Petrópolis: Vozes, 2002.

SAMPAIO, Rafael. Propaganda de A a Z. $3^{\text {a }}$ Edição. Rio de Janeiro: Elsevier, 2003.

SANDMANN, Antônio José. A linguagem da propaganda. $10^{a}$ Edição. São Paulo: Contexto, 2014. 
SANT'ANNA, Armando, 1929-2001. Propaganda: teoria, técnica e prática. $7^{a}$ Edição. São Paulo: Pioneira Thomson Learning, 2005.

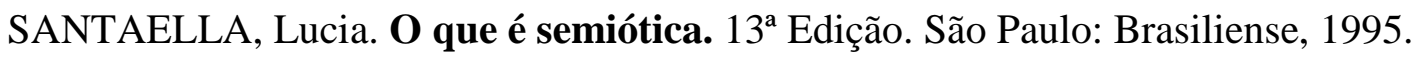

Comunicação e pesquisa: projetos para mestrado e doutorado. São Paulo:

Hacker Editores, 2001.

SANTOS, Maria de Fátima de Souza. A teoria das representações sociais. In: SANTOS, Maria de Fátima de Souza; ALMEIDA, Leda Maria de. (Org.) Diálogos com a teoria das representações sociais. Recife: Editora Universitária, 2005. P. 15-35.

SCHRAMM, Wilbur Lang. The beginnings of communication in America: a memoir. Thousand Oaks: SAGE Publications Inc., 1997.

SEBRAE, Serviço Brasileiro de Apoio às Micro e Pequenas Empresas. Manual de gestão das metas mobilizadoras. Brasília: SEBRAE, 2009.

. Sebrae 2022: Mapa Estratégico do Sistema Sebrae. Brasília: SEBRAE, 2012.

O público-alvo do Sebrae. Série Estudos e Pesquisas. Brasília: SEBRAE, 2012a.

Relatório de gestão do exercício de 2012: Sistema Sebrae. Brasília: SEBRAE, $2012 b$.

. Sebrae 40 anos: uma história do desenvolvimento brasileiro. Brasília: SEBRAE, 2012c.

Perfil do microempreendedor individual 2012. Série Estudos e Pesquisas. Brasília: SEBRAE, 2012d.

Perfil do microempreendedor individual 2013. Série Estudos e Pesquisas. Brasília: SEBRAE, 2013. 
Sebrae: um agente do desenvolvimento. Disponível em:

<http://www.sebrae.com.br/customizado/sebrae/1129-sebrae-um-agente-dedesenvolvimento/BIA_1129>. Acesso em: 16 set. 2013a.

5 anos - Microempreendedor individual - MEI: um fenômeno de inclusão produtiva. Brasília: SEBRAE, 2015.

Com as soluções SEI você aprende a cuidar bem do seu negócio. Disponível em: <http://www.sebrae.com.br/sites/PortalSebrae/sebraeaz/Com-as-soluções-SEI-vocêaprende-a-cuidar-bem-de-seu-negócio>. Acesso em: Abr. 2015.

SÍNTESE, Pesquisa e Análise. Pesquisa qualitativa Sebrae. Brasília, SEBRAE, 2009. 50p.

SPINK, Mary Jane P.; MEDRADO, Benedito. Produção de sentido no cotidiano. In: Práticas discursivas e produção de sentidos no cotidiano. SPINK, Mary Jane P. (Org). Rio de Janeiro: Cortez, 2004. P 22-41.

TAYLOR, Shelley E. Health psychology. In: BAUMEISTER, Roy R.; FINKEL, Eli J. (Org.). Advanced social psychology. Nova York: Oxford University Press, 2010. P. 697-731.

THOMPSON, John B. Ideologia e cultura moderna: teoria social crítica na era dos meios de comunicação de massa. Petrópolis, RJ: Vozes, 1995.

WOLF, Mauro. Teoria das comunicações de massa. São Paulo: Martins Fontes, 2003.

WOMEN'S AID. Women's Aid Campaigns. Disponível em:

<http://www.womensaid.org.uk/>. Acesso em: Set. 2014.

YANAZE, Liriam Luri Yamaguchi. Reflexos da cultura da mulher ocidental na mulher japonesa por meio da publicidade - Uma análise com abordagem sociossemiótica. In: BARBOSA, Ivan Santos (Org.). Os sentidos da publicidade: estudos interdisciplinares. São Paulo: Pioneira Thomson Learning, 2005. P. 51-70 